Universidade de Brasília - UnB

Instituto de Ciências Sociais - ICS

Departamento de Antropologia - DAN

Programa de Pós-Graduação em Antropologia Social - PPGAS-UnB

Educação formal e saúde alopática entre os Tapayúna (Kaykwakhratxi)

Aluno: Martiniano Alcântara Neto Matrícula: 12/003015

Orientador: Prof. Dr. José Antônio Vieira Pimenta.

Brasília, dezembro de 2016 
Universidade de Brasília - UnB

Instituto de Ciências Sociais - ICS

Departamento de Antropologia - DAN

Programa de Pós-Graduação em Antropologia Social - PPGAS

Educação formal e saúde alopática entre os Tapayúna (Kaykwakhratxi)

Martiniano Sardeiro de Alcantara Neto

Tese de Doutorado apresentada ao Programa de Pós-Graduação em Antropologia Social da Universidade de Brasília, como requisito parcial para obtenção do grau de Doutor em Antropologia Social.

Orientador: Dr. José Pimenta 


\section{Educação formal e saúde alopática entre os Tapayúna (Kaykwakhratxi)}

Tese de Doutorado apresentada ao Programa de Pós-Graduação em Antropologia Social da Universidade de Brasília, como requisito parcial para obtenção do grau de Doutor em Antropologia Social.

O candidato foi considerado pela banca examinadora.

Professor Doutor José Antônio Vieira Pimenta - Orientador PPGAS/DAN/UnB

Professor Doutor Roque de Barros Laraia PPGAS/DAN/UnB

Professora Doutora Silvia Maria Ferreira Guimarães

$\mathrm{DAN} / \mathrm{UnB}$

Professor Doutor Gersem José dos Santos Luciano DPA/PROEXTI e FACED/UFAM

Professora Doutora Rita Gomes do Nascimento Ministério da Educação/MEC

Prof. Dr. Luís Abraham Cayón Durán (suplente) PPGAS/DAN/UnB

Brasília, 15 de dezembro de 2016 


\section{Agradecimentos}

Inicialmente, agradeço o suporte dos meus pais, Edith Rodrigues Afonseca e Anísio Sardeiro de Alcântara. No quinto e último ano de doutorado, durante o fechamento da escrita, quando eu já não contava com nenhuma bolsa de pesquisa, foram eles, principalmente, que me apoiaram, de todas as maneiras, para que eu pudesse finalizar o texto que se segue. Além deles, agradeço aos meus irmãos Rafael Rodrigues de Alcântara, Cíntia Rodrigues Alcântara Marques e Anísio Sardeiro de Alcântara Júnior, principalmente pelo suporte financeiro durante os últimos meses de campo e também durante a escrita. Dentre meus familiares, agradeço ainda ao tio João é à tia Cecy. Eles abriram sua casa para mim nas proximidades da Universidade de Brasília e me trataram como um filho, além de também terem me ajudado financeiramente.

Agradeço aos também pós-graduandos freqüentadores da Kata(cumba): Chiquinho, Gui, Alexandre, Bruner, Jú, Graci, Izis, Nat, Rana, Lê, Paloma, Richarlison, Leidiane, DiDeus, Rafa, Júlia, Pedro, Fabiano Souto, Goiás, Francisco Tukano, entre outros que agora não me recordo. Sou especialmente grato ao Fabiano Bechelany, que compartilhou livros, experiências, conhecimento antropológico e o campo comigo, tendo também pesquisado na mesma região do norte do Mato Grosso. Agradeço ainda à antropóloga Daniela Batista de Lima. Conversamos informalmente em diversas ocasiões diferentes, compartilhando impressões, nos atualizando reciprocamente sobre as constantes novidades que sempre apareciam no cotidiano da aldeia Kawerêtxikô dos Tapayúna. À professora Andréa Lobo pelo ótimo curso de Organização Social e Parentesco. Entre os antropólogos, agradeço, por fim, à Leonor Valentino, que me acompanha, de diferentes distâncias, desde que me arvorei a tentar ser um deles.

Devo muito à ajuda que os funcionários do DAN Jorge Máximo, Caroline Greve e Rosa Cordeiro me deram. Desde os cigarros cedidos por Rosa, aos pendrives achados e retornados por Caroline até as datas confirmadas por Jorge.

Agradeço pelas ocasiões etílicas de desanuviamento proporcionadas pelos amigos Cone, Fernanda, Paloma, PT, Tiaguinho, Sapeca, Guth, Jimmy, Renato, José, Ada, Violeta, Rafaela, Luciano, Rainri, Rodney, Juca (in memorian), Ed, Ricardo, Jana, Carla, Joana, Julia, Alexandre, entre outros que não irei lembrar agora. Devo muito ao companheirismo de todos os dias e ao infinito carinho da Clarisse Moreira Aló.

Em Kawerêtxikô, sou particularmente grato a Orengô Tapayúna, Wengroi Tapayúna, Wotkàtxi Tapayúna, Nokêrê Tapayúna e Roptyktxi Tapayúna. Agradeço também a toda população da aldeia que franqueou meu trabalho de campo com curiosidade e entusiasmo.

Agradeço, por fim, ao professor José Pimenta pela paciência e afinco na orientação de um caótico pisciano. Ele fez muitos mais do que aquilo que normalmente se espera de um orientador.

A pesquisa e, consequentemente, o texto que se segue contaram com bolsa de pesquisa de doutorado do Conselho Nacional de Desenvolvimento Científico e Tecnológico (CNPq) durante os primeiros quatro anos do doutoramento (2012-2015). Ainda que a vida de pesquisador mantida pela bolsa seja quase-que-espartana, ela, ao menos, garante a possibilidade de uma vida de pesquisador. 
Esta tese é dedicada aos Tapayúna pela tentativa de me enxergar como algo mais do que apenas um não-indígena. 


\section{Resumo}

A tese a seguir a seguir trata das relações dos Tapayúna da aldeia Kawerêtxikô (Parque Indígena do Xingu, Terra Indígena Capoto Jarinã, Mato Grosso) com a educação escolar e a saúde alopática oferecidas pelo Estado brasileiro a eles durante os anos de 2012 a 2015. O foco principal foi o de mapear as interpretações nativas sobre esses dois serviços permanentemente instalados na aldeia Kawerêtxikô, comparando as relações dos Tapayúna com essas duas áreas. As minhas considerações se baseiam em um período de pesquisa e convivência cotidiana entre os Kaykwkhratxi (auto-denominação dos Tapayúna, pertencentes ao tronco lingüístico e à família Jê) de 13 meses não-consecutivos, além da companhia e observação das viagens que eles faziam às cidades do entorno da Terra Indígena Capoto Jarinã, tradicional território dos Kayapó (Mebengôkrê) e onde foi construída a aldeia Kawerêtxikô. Dei especial atenção à maneira como os Tapayúna eram interpelados e, ao mesmo tempo, também interpelavam os funcionários do posto-de-saúde e da Escola Goronã. Por fim, analiso, a partir da noção de dupla ou múltipla-submissão, como a população não-indígena em geral acaba por tentar classificar e subjugar os Tapayúna e toda a população indígena daquela região do norte do Mato-Grosso, principalmente nos municípios de Peixoto de Azevedo, Colider e São José do Xingu. 


\begin{abstract}
The following thesis is about the relationship of the Tapayuna indigenous people (South America, Brazil, Mato Grosso) with the public education and the public health systems permanently offered to them by the Brazilian State in Kawerêtxikô village, during the years 2012 to 2015 . The main focus was to map the native interpretations about these two services, comparing the relationships of people from Kawerêtxikô in the two areas. My considerations are based in 13 non-consecutive months of coresidency with Kaykwakhratxi people (Tapayúna's self-nomination, belonging to Jê linguistic family). In the same period, I could also observe and follow them when they were visiting the surrounding cities in the region. The Kawerêtxikô village is located in Terra Indigena Capoto Jarinã (Indigenous Land Capoto Jarinã), which is the traditional territory of the Kayapó people (self-called Mebengôkrê, also a Jê linguistic group). I particularly focus on in how Tapayúna were inquired by and, at the same time, positively inquired the non-indigenous population who worked in the Health Station and the Escola Goronã (Goronã School). Finally, I applied the category of double-submission or multiple-submission in trying to understand the broad relationship between indigenous people (particularly the Tapayúna people) and the non-indigenous population in the surrounding urban area, mainly the cities of Peixoto de Azevedo, Colider and São José do Xingu, all of them located in the north of the state of Mato Grosso, Brazil.
\end{abstract}


Índice

Introdução .11

Capítulo 1. A educação e a saúde indígenas em perspectiva: uma breve reconstituição histórica e um panorama dos estudos

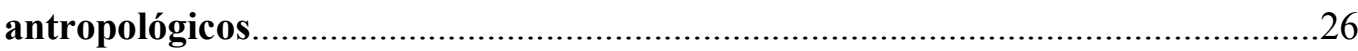

1.1 Uma perspectiva histórica da educação formal e da saúde alopática para os indígenas no Estado brasileiro.

1.2 Os estudos sobre educação formal indígena na antropologia brasileira .38

1.3 Os estudos sobre saúde alopática entre os indígena .58

1.4 Os estudos de educação formal e saúde alopática entre os indígenas em uma perspectiva comparada. 68

Capítulo 2. Os Tapayúna e os outros: relações interétnicas no Xingu. 74.

2.1 Os primeiros contatos dos Tapayúna com os não-indígenas e a fuga para o PIX .77

2.2 O convívio dos Tapayúna com os Kinsedje. 81.

2.3 Vivendo entre os Kayapó da Terra Indígena Capoto Jarinã. 85. 
2.4 A balsa da BR-080 e a relação com os Mebengôkrê 91.

2.5 As discussões sobre o dinheiro da balsa em Kawerêtxikô. 101.

Capítulo 3. Uma etnografia da educação formal entre os Tapayúna 113.

3.1 A origem dos nomes próprios: goronã e o englobamento do contrário 117

3.2 A Escola Goronã de Kawerêtxikô: uma instituição tapayúna 123.

3.3 Uma etnografia das aulas na Escola Goronã 133.

3.4 A educação formal em Kawerêtxikô em perspectiva. 153.

Capítulo 4. Uma etnografia da saúde alopática em Kawerêtxikô 160.

4.1 A dupla submissão: assimetrias em uma discussão no cotidiano de um plantão 164

4.2 Falta de higiene, placebo e corpos frágeis: a alopatia em Kawerêtxikô. 177.

4.3 As Casais, a comunicação via rádio e os "pacientes" e acompanhantes 187.

4.4 Uma visão geral da terapêutica indígena contraposta à alopatia 192.

Conclusão. .200 
O wajanja entre aqueles que sabem

204.

A dupla submissão no contexto da educação formal em Kawerêtxikô 209.

Bibliografia em ordem alfabética

213

Anexos

225.

Lista de Mapa e Imagens

Esquema 01 .11

Mapa 01 .78

Mapa 02 92

Imagem 01 124.

Imagem 02 129.

Imagem 03 167. 


\section{Introdução}

A tese que apresento não é propriamente sobre os Tapayúna ou os Kaykwakhratxi, grupo da família e tronco linguísticos Jê, habitantes da aldeia Kawerêtxikô (Esquema 01) na Terra Indígena Capoto Jarinã, extremo norte do Mato Grosso, Brasil. Apesar de quase todo meu período de campo ter sido feito na supracitada aldeia, minha preocupação, nesta tese, é analisar as relações desse grupo com a educação e saúde públicas oferecidas a eles pelo Estado brasileiro, diretamente em Kawerêtxikô. Falarei, por vezes, da relação interna entre os indígenas dessa aldeia. Em outras ocasiões, também do elo entre os Kaykwakhratxi e os Mebengôkrê, entre outros indígenas. Do mesmo modo, em alguns momentos precisarei esclarecer melhor o trato entre os Tapayúna e a população não-indígena em geral, principalmente a citadina, que circunda a região da Terra Indígena Capoto Jarinã. Toda a descrição e análise dessas últimas conexões tem um único propósito: lançar luz sobre a relação desses indígenas com o posto-de-saúde e a escola de educação formal, ambos implantados dentro - ou, mais exatamente, nas imediações (Esquema 01) - da aldeia Kawerêtxikô. Portanto, os habitantes dessa aldeia serão analisados na medida em que interpelaram ou foram interpelados por essas duas instituições, direta ou indiretamente.

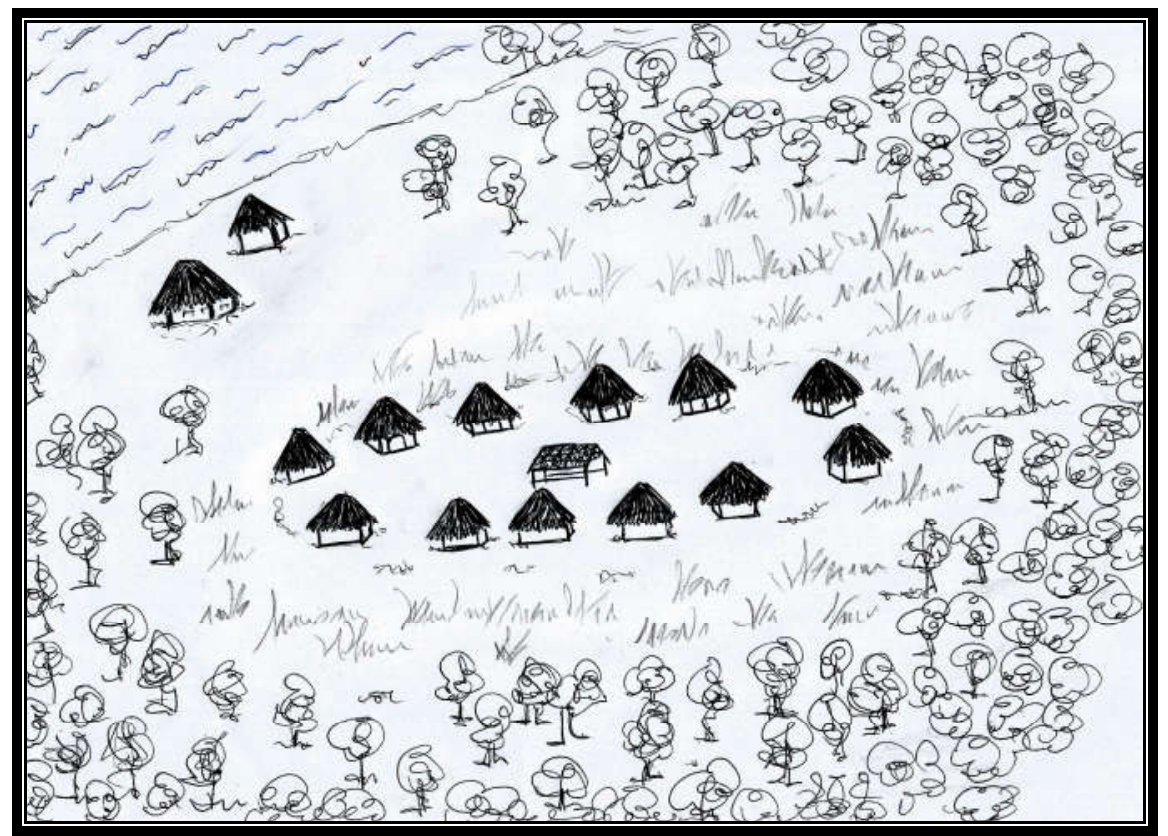

Esquema 01: a aldeia Kawerêtxikô dos Tapayúna (arte por Clarissse Aló). As duas casas fora do círculo da aldeia, no caminho para o rio Xingu, são o posto-de-saúde (acima) e a escola (mais abaixo). No centro do círculo está a Casa dos Homens. A mata mais clara imediatamente externa ao círculo são 
zonas de roças em uso ou desuso. A mata mais escura, na borda externa do esquema, representa a densa floresta da região. A população total da aldeia era de cerca de 150 pessoas, divididas nas 12 casas comunais.

Deste modo, minha análise, na presente tese, coloca em 'vizinhança' e, portanto, também em contraste, dois tipos relativamente distintos de dados etnográficos sobre os Tapayúna da aldeia Kawerêtxikô. Meu objetivo é, então, comparar duas instituições sociais que são geograficamente vizinhas e sociologicamente 'aparentadas' nessa aldeia: a Escola Goronã e o posto-de-saúde. Reconheço de antemão uma 'parentalidade' entre essas duas instituições, pois, além de terem uma origem não-indígena, ambas são sustentadas financeiramente pelo erário público. As duas tem projetos de se adequar às especificidades do grupo indígena onde estão instaladas - todavia, elas cumprem tal meta em diferentes graus, como veremos. Além disso, ambas possuem estruturas físicas erguidas por homens tapayúna do lado de fora do tradicional círculo de casas da aldeia Kawerêtxikô, ocupando locais relativamente próximos um ao outro, à margem do Rio Xingu. Uma contextualização mais pormenorizada da história e da região atualmente habitada pelos Tapayúna será feita no capítulo 2 .

Adianto aqui a natureza do trabalho de pesquisa que realizei nessa região. Nos 13 meses não-consecutivos que pude conviver entre os Tapayúna, aprendi rudimentos da língua Kaykwakhrátxi (tronco e família Jê). Conseguia entender o tema geral e, por vezes, algumas sentenças das conversas que ocorriam, sempre ao entardecer, no centro do pátio da aldeia, a chamada "Casa dos Homens" ou "Casa dos Guerreiros", na fala dos homens que dominavam o Português. Aprendi também algumas frases e expressões, principalmente cumprimentos, de Mebengôkrê, auto-denominação da língua e do grupo dos Kayapó (tronco e família Jê), ocupantes tradicionais da Terra Indígena Capoto Jarinã. Realizei minhas incursões entre o final de 2012 (novembro/dezembro) e o início de 2015 (fevereiro). No período em que estive em campo, passava cerca de 20/30 dias em Kawerêtxikô e, depois desse tempo, uma semana em alguma cidade de região, digitando e fazendo backup na Internet de notas de campo, preparando um novo rancho e dando notícias aos familiares e orientador. Essas idas e vindas se tornaram uma rotina, principalmente entre os anos de 2014 2015. Ainda que os centros urbanos não tenham sido o foco principal da pesquisa, pude também acompanhar alguns homens, mulheres e crianças indígenas, além de 
funcionários não-indígenas do posto-de-saúde, de diversas origens, enquanto estavam na cidade. Os municípios mais visitados pelos indígenas e por mim foram os de Peixoto de Azevedo, Colider e São José do Xingu - todos pertencentes ao norte do estado de Mato Grosso.

O meu primeiro contato com os Tapayúna se deu sem a intenção formal de fazer pesquisa entre eles. Em novembro de 2012, a então funcionária da Fundação Nacional do Índio (Funai) de Brasília, Maria Eliza Leite, havia organizado mais uma etapa de um curso de produção de material didático para alfabetização de estudantes nas línguas nativas Mebengôkrê, Tapayúna e Panará. O curso iria acontecer na aldeia mebengôkrê de Piaraçu ${ }^{1}$. Fui convidado por ela a compor o grupo de não-indígenas que ajudaria em tal empreitada, principalmente assessorando os professores indígenas das três etnias nos textos em Português. Com isso, as aulas visavam não somente a produção de material didático de alfabetização nas línguas maternas, mas também assessorava os professores indígenas na escrita, fala e usos cotidianos do Português. Por exemplo, a equipe da Funai utilizou um manual para falantes de Português como segunda língua, onde uma das atividades era dar e conseguir informações, em Português, quando se visitava uma cidade. O objetivo era tornar os professores indígenas, todos falantes do Português como segunda língua, mais preparados para visitar os núcleos urbanos da região em ocasiões de necessidade, como reuniões pedagógicas, feitura de compras ou a retirada de seus salários. Assim, para dar outros exemplos, os professores indígenas também foram ensinados a preencher cheques e a usar os pronomes de tratamento adequados quando fossem cumprimentar algum nãoindígena na cidade.

Durante todo o mês de novembro e parte de dezembro 2012 estive, então, ocupado no curso que Maria Eliza organizara. Nesse contexto, fiquei responsável por assessorar mais detidamente a lingüista Nayara Camargo no trabalho com uma das etnias do curso: os Tapayúna. Essa pesquisadora, ao mesmo tempo em que recolhia dados para sua tese de doutorado em lingüística (Camargo, 2015), ajudava os Tapayúna na composição de um livro didático em Kaykwakhratxi - termo que os

\footnotetext{
${ }^{1}$ Como mostrarei no capítulo 2, Piaraçu é uma aldeia atípica quando comparada a outras aldeias da região. Adianto, de todo modo, que é preferencialmente para lá que os Tapayúna formados vão depois de completar os estudos na sua aldeia: Piaraçu é a única na região que oferece o ensino médio (para mais informações, cf. capítulo 3). Além disso, é uma das únicas que possui distribuição pública de luz elétrica, o que, nas outras aldeias, é obtido comprando-se caras placas solares, baterias e inversores elétricos DC/AC, que dão acesso a uma corrente elétrica instável e fugaz.
} 
Tapayúna usam para se referir a si próprios e a sua própria língua. Nayara Camargo ajudava-os a criar, assim, uma convenção de escrita para uma língua que, até então, só havia sido usada oralmente. É nesta convenção, que ainda está em processo de debate e assimilação pelos Tapayúna, que me baseio para glosar os termos na língua Kaykwakhratxi.

Nayara Camargo me disse, então, que os Tapayúna estavam necessitando de alguém para ajudá-los numa possível denúncia pública de genocídio. Os Panará, outra etnia que participava do curso da Funai, tiveram sucesso em uma ação judicial deste tipo e os Tapayúna queriam seguir o mesmo caminho, pleiteando uma indenização pelas tentativas de genocídio que também sofreram ${ }^{2}$. Comentei com a lingüista que eu havia estudado, durante o mestrado, o processo judicial da condenação de um grupo de garimpeiros brasileiros que chacinaram os Yanomami da aldeia Haximu, na década de 90 (Alcântara Neto, 2007). No outro dia, Nayara Camargo me disse que os Tapayúna haviam me convidado para fazer pesquisa entre eles. Eu teria livre acesso às festividades, técnicas e costumes em geral e, em contrapartida, os ajudaria a compor a já citada denúncia. Depois de alguns dias refletindo, resolvi aceitar o convite dos Tapayúna.

O contexto da minha inserção entre os Tapayúna tem relação direta com o artigo do antropólogo Bruce Albert que analisa o trabalho de campo na Antropologia Social depois da $2^{\text {a }}$ Grande Guerra Mundial (Albert, 1997). Como a criação de organismos supra-nacionais duradouros, como Organização das Nações Unidas, $\mathrm{ONU}^{3}$, além da organização dos não-indígenas em novos modelos de atuação política, como as Organizações Não-Governamentais - ONGs, o papel do antropólogo frente às populações nativas vai gradualmente tomar novas formas. A presença incômoda do pesquisador entre os nativos vai ser suportada pelos últimos não mais "apenas" a partir de mitigadas doações de tabaco (Malinowski, 1976), mas principalmente com base em uma práxis política que fortaleça os indígenas nas assimétricas relações com os novos e antigos Estados nacionais. Os Tapayúna exigiam, assim, que o Estado reconhecesse e os indenizasse pela tentativa de genocídio que sofreram durante os

\footnotetext{
2 Os Panará conseguiram uma indenização, em 2001, de cerca de 1 milhão de reais. Com ela, eles puderam voltar e efetivamente retomar parte do seu território tradicional.

${ }^{3}$ Lembro aqui que as instituições supra-nacionais criadas após a $1^{\text {a }}$ Guerra Mundial, como a Liga das Nações ou a Organização Internacional do Trabalho (OIT) foram inseridas à ONU (caso da OIT) ou então deixaram de existir (caso da Liga das Nações).
} 
primeiros contatos com os brasileiros. Esse tipo de movimento é bem situado e descrito por Bruce Albert quando ele argumenta que:

Since the 1970s, indigenous communities and organizations have been openly questioning the purpose and consequences of anthropological study in relation to their own projects for selfdetermination. [...] Yet far from leading to a mere condemnation of anthropology, this situation has created an increasing demand for anthropological involvement. (Albert op. cit. :56)

Como o próprio autor nota, não é simplesmente o fim do trabalho de campo, mas sua reinserção em um novo contexto político em que os indígenas passam a ter ao menos um mínimo poder de barganha e ação direta. Assim, os Kaykwakhratxi negociavam comigo, pela primeira vez, as condições em que admitiriam minha presença entre eles. É exatamente esse o ponto de Albert quando argumenta que a observação participante "is no longer merely 'participant'; his social 'participation' has become both the condition and the framework of his [do antropólogo] field research." (idem $: 58)$.

Desde o primeiro contato com os Tapayúna, nas oficinas de linguística, os professores (todos homens) desse grupo apresentaram interesse em saber falar e escrever em Inglês. Esse foi mais um acordo que fizemos: eu lhes ensinaria essa última língua, enquanto eles me ensinariam Kaykwakratxi. Efetivamente, no final do ano de 2013 e início do ano de 2014, eu dei aulas de Inglês durante alguns meses aos homens adultos da aldeia Kawerêtxikô. Esses encontros aconteciam na pequena escola da aldeia, a Escola Estadual Goronã, no período em que as aulas regulares do ensino fundamental $\left(1^{\circ}\right.$ ao $9^{\circ}$ ano $)$ já haviam terminado e ainda não havia se iniciado a reunião diária na Casa dos Homens.

Em contrapartida, todos, principalmente os homens adultos, se esforçaram para que eu aprendesse o máximo possível de Kaykwakratxi. As aulas que eu recebia na língua Tapayúna eram menos formais que as minhas de Inglês. Elas se davam nas visitas diárias que eu fazia às diversas casas da aldeia ou, por outro lado, quando alguém me visitava na casa de um professor tapayúna, Orengô Tapayúna, onde fui gentilmente acomodado em minha primeira estada de maior duração - a partir de 
maio de 2013. Deitados na rede, sentados em um banco ou mesmo no chão de terra, os homens alfabetizados me davam aulas escrevendo com o dedo na areia do solo. Algumas vezes, a meu pedido, ocupávamos a Escola Goronã e usávamos o quadro de giz que lá se encontrava, no intuito de escrever frases maiores e mais complexas em Kaykwakhratxi.

Nas aulas de Inglês, havia uma única jovem tapayúna, que acompanharia somente os primeiros encontros ${ }^{4}$. Ela, invariavelmente, sentava nas últimas carteiras, o mais distante possível do quadro e de mim. É interessante notar, nesse contexto, que eu nunca fui interpelado por uma mulher tapayúna para tirar dúvidas de Inglês, algo que acontecia cotidianamente com os homens, mesmo fora do período das aulas. Uma das únicas vezes que uma mulher falou diretamente comigo, sem que eu tenha começado ou insistido na conversa, foi Kawetxi Tapayúna, senhora de cerca de 60 anos e reconhecidamente uma liderança da aldeia. Ela me interpelou algumas vezes, em língua materna ${ }^{5}$, sobre o andamento da carta de denúncia de genocídio que havia ficado responsável por produzir.

A minha primeira e principal 'porta de entrada' em campo foi, portanto, o ensino formal. Assim, durante, por exemplo, o já citado curso de Maria Eliza Leite, eu e a linguista Nayara Camargo passávamos todas as folgas de domingo em viagens à aldeia Kawêrêtxikô. Esta localidade se situa algumas horas de barco da aldeia mebengôkrê de Piaraçu. Nessas ocasiões, produzimos a primeira listagem com os nomes dos mortos dos atos de genocídio de não-indígenas contra os Tapayúna (Anexos). A carta de denúncia do genocídio foi entregue, no começo de 2015, à área jurídica da Funai de Brasília. O começo de uma denúncia juridicamente fundamentada também foi deixada nessa instituição, na mesma ocasião. Agradeço, para tanto, a preciosa ajuda dos Advogados Sem Fronteiras (ASF) ${ }^{6}$. Até hoje não há qualquer posicionamento da Funai sobre o caso. Atualmente, a antropóloga Daniela Batista de

\footnotetext{
${ }^{4} \mathrm{O}$ mesmo aconteceu no curso já citado da Funai: a maioria quase absoluta era de homens, professores indígenas das três etnias. Consegui identificar, nessa ocasião, apenas duas mulheres acompanhando as aulas - de um total de cerca de 40 estudantes. Havia também uma anciã tapayúna que ajudava a linguista Nayara Camargo na pronúncia de determinadas palavras - existia, assim, uma diferença de pronúncia a ser notada entre o jovem professor Orengô e essa antiga anciã e seu marido, que estava sempre junto dela. Há de se notar, contudo, que tal mulher não é professora da Escola Goronã.

${ }^{5}$ Meu tradutor nessa ocasião e em todas as outras que tive contato com o Kaykwakhratxi foi Orengô Tapayúna. Para o Mebengôkrê, também contei com a ajuda de Kokokuntxi Metyktire.

6 Tive contato com essa organização internacional, sem fins lucrativos, a partir da mediação da antropóloga Leonor Valentino de Oliveira, a quem também agradeço. A ASF visa, basicamente, dar assessoria jurídica a grupos que não podem arcar com o custo financeiro da mesma.
} 
Lima, que também faz pesquisa em Kawerêtxikô, conseguiu uma audiência para as lideranças tapayúna em Brasília, na $6^{\text {a }}$ Câmara de Coordenação e Revisão - Índios e Minorias, do Ministério Público Federal (MPF), no propósito de combater o imobilismo do órgão indigenista oficial.

De todo modo, é imperioso notar que o contato com os Tapayúna somente foi possível a partir do trabalho no curso de formação de professores de Maria Eliza Leite. Foi também essa funcionária da Funai que me deu as informações iniciais de onde encontrar material para alicerçar etnológica e juridicamente a primeira versão da carta de denúncia do genocídio.

As aulas de língua inglesa, inicialmente com quase todos os homens falantes de Português de Kawerêtxikô, foram gradualmente se tornando mais e mais vazias, até que, depois de pouco mais de três meses, acabaram por falta de estudantes. Os homens jovens estavam todos treinando, depois das aulas formais da Escola Goronã, para a Copa de Futebol de São José do Xingu, campeonato que junta times masculinos de futebol formados por indígenas e não-indígenas na referida cidade do extremo norte de Mato Grosso. Os Tapayúna defendiam o título conseguido no ano anterior, em 2013. Continuei, de todo modo, ajudando os Tapayúna no ensino formal, agora com aulas esporádicas de língua portuguesa, matemática e biologia principalmente a biologia evolucionista darwiniana, sob a qual os Tapayúna tem uma curiosidade particular. Também pude ajudá-los a revisar o Plano Político e Pedagógico $^{7}$ (PPP) da Escola Goronã que, ao contrário do que diz a Constituição de 1988, precisou ser escrito em Português e nos moldes das escolas não-indígenas. Além disso, produzi diversos outros documentos nessa língua a pedido dos Tapayúna, como a digitação do mito $O$ homen que virou onça para o estudante de licenciatura indígena Wengroi Tapayúna (em Português e em Kaykwakhratxi), pedidos de miçanga ao Instituto Raoni (somente em Português, mas assinado pelo cacique Roptyktxi Tapayúna e outras lideranças da aldeia) ou cartas para as prefeituras dos municípios da região, cobrando investimentos em Kawerêtxikô.

Se minha primeira e principal 'porta de entrada' para a pesquisa na aldeia, além da assessoria antropológica no processo de genocídio, foi a Escola Goronã e o

\footnotetext{
${ }^{7}$ Uma das reclamações constantes dos Mebengôkrê de Piaraçu, durante o curso da Funai em 2012, era que os cursos oferecidos pela Secretaria de Educação do Mato Grosso já viam prontos, inclusive com um Plano Político e Pedagógico já escrito e a temática das aulas já escolhida. O curso de Maria Eliza, ao contrário, só começava depois que os próprios indígenas decidissem o que iriam estudar naquela ocasião específica.
} 
ensino formal, minha 'válvula de escape' foi a saúde alopática oferecida no posto-desaúde de Kawerêtxikô. Quando a tentativa de socializar com totais desconhecidos e aprender uma língua completamente nova para mim se tornava um tormento, era para esta última localidade que eu recorria. Eu sabia que iria encontrar lá alguma pessoa fluente em Português, não-indígena e não diretamente interessada nos assuntos próprios da sociabilidade dos Tapayúna - ao menos aqueles não relacionados à saúde dos corpos. Depois de algumas horas conversando com a técnica de saúde que então estava responsável pelo posto - ou, por vezes, com a enfermeira e outros profissionais que faziam visitas periódicas à Kawerêtxikô - eu estava revigorado para continuar a pesquisa entre os Tapayúna.

Com o passar de alguns meses vivendo na casa de Orengô Tapayúna, junto com sua esposa e cinco filhos, resolvi me mudar para o posto-de-saúde de Kawerêtxikô. Vários foram os motivos que me levaram a tomar essa decisão. $\mathrm{O}$ principal era que minha pesquisa estava financeiramente comprometida, já que eu não dispunha, naquele momento, de qualquer outro recurso que não minha bolsa de doutorado do Conselho Nacional de Desenvolvimento Científico e Tecnológico (CNPq). Tal comprometimento se deu, sem dúvida, mas não exclusivamente, na tentativa de construir laços de dádiva e contra-dádiva (Mauss, 1974) com a população de Kawerêtxikô. Não é incomum que não-indígenas sejam vistos pelos indígenas em uma posição exageradamente superior no que tange ao acesso aos bens materiais dos próprios não-indígenas. Esse foi um dos problemas, por exemplo, da pesquisa de Cesar Gordon (2006) entre os Xikrin no estado do Pará e se tornou uma questão a ser contornada em minha própria pesquisa ${ }^{8}$.

Além de presentes especiais de chegada, como material de pesca, facas, lanternas, miçangas de qualidade, vestidos para as mulheres, tabaco, entre outros, todos inicialmente em grande quantidade, eu havia me comprometido a colaborar com o rancho (refeições e bebidas não-alcoólicas) na casa de Orengô Tapayúna. Apesar

\footnotetext{
${ }^{8}$ No curso da Funai, em 2012, não só os professores indígenas tomavam parte das três refeições oferecidas: também as crianças, as mulheres e os velhos se juntavam a nós para comer, sempre. Por esse motivo, Maria Eliza precisou comprar mais provisões do que havia inicialmente planejado. Contudo, ela nunca pensou em restringir a comida aos participantes do curso, como fazia a organizadora das aulas da Secretaria Estadual de Educação, motivo pelo qual esta última era tida como pontualmente sovina pelas várias etnias que freqüentavam seu curso em Piaraçu. Não sei se minha mudança da casa de Orengô para a farmácia me valeu o mesmo rótulo. Contudo, não fosse tal mudança, a tese que agora apresento ou não existiria ou seria sobre alguma outra temática que não a comparação entre saúde alopática e educação formal.
} 
dessa última residência ter como ocupantes fixos apenas a família nuclear do professor tapayúna, a comensalidade cotidiana extrapolava em muito essa família. Comiam conosco, gradativamente, toda a família extensa e afins de Orengô, o que me levou a gastar, apenas em um único mês, cerca de 700 reais exclusivamente com comida e bebida não-alcoólica trazidas dos núcleos urbanos da região. Além disso, os Tapayúna me deram um nome em Kaykwakrhatxi e me inseriram dentro de seu sistema de parentesco, o que demandava mais gastos específicos com meus parentes afins. Quando eu não conseguia alguma carona com os não-indígenas da saúde alopática, como descrito no Capítulo 2, eu era obrigado a gastar com o translado da aldeia para algum centro urbano da região: fretes de carros particulares, passagens de ônibus, compra de gasolina e óleo dois tempos para o barco que me levaria à Kawerêtxikô eram as despesas mais comuns nessa situação. Por fim, quase todas as ocasiões em que fiquei nas cidades do entorno do Parque Indígena do Xingu (PIX), eu era obrigado a me hospedar em um hotel. Juntando tudo isso, minha pesquisa era financeiramente inviável apenas com a bolsa do CNPq.

Apresentei esse problema à Orengô e Wengroi, os dois homens tapayúna de quem eu era mais próximo naquele momento - ambos então professores da Escola Goronã. Atualmente, Wengroi se tornou o diretor dessa instituição, substituindo Txuakrê Metyktire, como descreverei mais detalhadamente no capítulo 3. Eles concordaram com meu argumento de que, caso eu continuasse vivendo do mesmo modo, não conseguiria completar os 12 meses mínimos em campo que havíamos acordado. Assim, apesar de ter passado os primeiros três meses hospedado na casa de Orengô, no restante da pesquisa compartilhei estadia com as técnicas de saúde do posto ou farmácia de Kawerêtxikô. Na saída, deixei um presente para Orengô e sua esposa pela hospedagem que me disponibilizaram: um fogão a gás usado, comprado na cidade de Peixoto de Azevedo.

Vivendo na nova residência, não notei quase nenhuma mudança nas relações sociais nas quais eu já estava comprometido. Contudo, meus gastos com o rancho básico diminuíram para menos da metade do que eu costumava gastar quando vivia dentro do círculo da aldeia. Assim, eu compartilhava a comida e o gás de cozinha com a funcionária do posto-de-saúde que estava de plantão e, além disso, combinava minha saída com essa mesma não-indígena, economizando também nos fretes, passagens e gastos gerais com os deslocamentos para os núcleos urbanos. Notei 
também que, gradualmente, eu ficava mais independente em campo, menos diretamente 'ancorado' à figura de Orengô ou de outros professores, tendo acesso mais franqueado a outras pessoas, como os homens mebengôkrê casados com mulheres tapayúna ou aos anciãos que só por vezes freqüentavam a Escola Goronã. Com isso, todos os habitantes de Kawerêtxikô sabiam onde facilmente me encontrar e eu podia circular na aldeia inteira, participando de festas e outros rituais sem ter que me preocupar com os horários em que a família de Orengô fazia suas refeições - o inverso também valia para eles. Além disso, os caçadores e pescadores da aldeia passaram a trocar ou doar comida comigo de maneira mais direta e freqüente: eu e a técnica de saúde éramos considerados, a partir de então, uma casa de troca relativamente independente ${ }^{9}$. Por exemplo, as festividades de troca generalizada, chamadas de moytara, percorriam todas as casas do círculo da aldeia e também faziam uma parada no posto-de-saúde, trocando comigo e com a funcionária que estivesse de plantão.

Foi dessa forma que se deu minha entrada e estadia entre os Tapayúna. Nesse contexto, pude conviver cotidianamente tanto com as funcionárias não-indígenas da saúde alopática, cuja etnografia mais detalhada pode ser encontrada no capítulo 4, como também com os professores tapayúna e seus alunos na Escola Goronã, tema do capítulo 3. Assim, foi-me possível acompanhar de perto as duas instituições públicas do Estado brasileiro que estão constantemente instaladas na aldeia Kawerêtxikô, já que residi tanto na casa de um professor indígena, acompanhando suas aulas e a de outros docentes, como também no lócus de trabalho da saúde alopática não-indígena: o posto-de-saúde ou farmácia. Pude passar, ainda, algumas semanas na aldeia mebengôkrê de Piaraçu, a maioria desse período enquanto assessorava o já citado curso da Funai - e, em outras ocasiões, quando ia para alguma cidade ou voltando para Kawerêtxikô, já que Piaraçu é o ponto do ônibus de linha e dos freteiros particulares que trabalham fazendo o translado aldeia Piaraçu/município de São José do Xingu, como deixarei claro no capítulo 2. Fiz também visitas pontuais a duas pequenas aldeias mebengôkrê nos arredores de Kawerêtxikô, sempre acompanhado de algum Tapayúna.

\footnotetext{
${ }^{9}$ Atualmente, há uma Casa do Antropólogo, também construída por homens tapayúna fora do círculo da aldeia. Contudo, ainda não tive oportunidade de ficar hospedado nessa construção. Daniela Batista de Lima, também doutoranda do PPGAS-DAN-UnB, me passou tal informação por correio eletrônico.
} 
Nesta introdução, gostaria ainda de justificar o uso que faço de duas categorias centrais para a presente análise: a de não-indígena e saúde alopática. Até aqui, venho usando o último termo de maneira bastante genérica. Tentarei, portanto, 'afiar' melhor esse conceito.

Se referindo a uma tradição ocidental de tratamento de doenças e outras anomalias, Cristina Dias da Silva (2010), em uma interessante tese sobre a saúde oferecida pelo Estado brasileiro aos Munduruku, explicitamente abre mão da categoria de "medicina ocidental" e usa, em seu lugar, o termo "biomedicina". Esse termo, sem dúvida, é caudatário de uma análise da terapêutica ocidental mais geral e com inspiração direta nos estudos de Michel Foucault.

Tal autora faz referência à pluralidade de terapias modernas de tratamento dos corpos (idem :06, nota de pé de página n. 05), e não a uma prática singular. Não nego, é claro, a existência dessa multiplicidade dentro da terapêutica não-indígena estatal. Contudo, como irei mostrar no capítulo 1 na análise do Ato Médico, não há uma relação simétrica entre as diversas especialidades que compõem a chamada "biomedicina" moderna. Além disso, o último termo pode ser motivo de confusão, já que os chamados "biomédicos" formam uma das categorias que se juntaram para combater, do outro lado, os médicos tradicionais (graduados em medicina e que passaram por um período de residência médica em alguma instituição de saúde nãoindígena) durante a luta política pelo não-reconhecimento do Ato Médico, como veremos no referido capítulo.

Carla Costa Teixeira, orientadora de Cristina Dias Silva no trabalho já citado, também prefere o uso do termo "biomedicina" (Teixeira, 2008a :346 e 2008b :974) ou, por vezes, "biomedicinas", no plural (Teixeira, 2012 :573), em diversos artigos relacionados à saúde indígena prestada pelo Estado brasileiro. Em um trabalho mais antigo (Teixeira e Silva, 2002), onde há um ótimo levantamento bibliográfico e uma análise preliminar da produção acadêmica nacional sobre a saúde indígena estatal, as duas autoras mapeiam, inclusive, quando as políticas de saúde pública do Estado brasileiro começaram a efetivamente se preocupar com os indígenas. Assim, segundo elas:

É interessante notar que, no processo histórico de construção de metas e de uma estrutura de saúde pública durante a Primeira 
República (1889-1930), no Brasil, o indígena não fazia parte das populações do interior eleitas como alvo das intervenções para tratamento de doenças endêmicas (Hochman \& Silva, no prelo). Apenas na década de 1940, com a expedição Roncador-Xingu e as consecutivas aberturas de rodovias, como a Belém-Brasília e a Transamazônica, a demanda por conhecer e produzir diagnósticos sobre as condições de saúde dos povos indígenas se tornou consistente. (idem :41)

Além de corroborar o breve histórico que irei apresentar no próximo capítulo, onde a população indígena, principalmente do interior, começa a ser mais pontualmente interpelada pelo Estado brasileiro somente depois da chamada Revolução de 1930, dando fim à Primeira República, as autoras fazem o mesmo uso do termo "biomedicina" (ibid idem :44, :45 e :47) para se referir à saúde não-indígena oferecida aos indígenas. Deste modo, em todas essas citações nesses diversos artigos, há sempre o cuidado de se referir à terapêutica não-indígena como não-monolítica, diversa ou multifacetada.

Reitero, mais uma vez, que não há como negar que a medicina no Ocidente não tem mais, se algum dia possuiu, o monopólio no tratamento dos corpos humanos. Também não há como negar que foi justamente a tradição médica ocidental que construiu, gradualmente, a própria ideia de um corpo humano que possa ser submetido a um tratamento comum - e, assim, em certo sentido, conformando um corpo único ou ao menos com a mesma estrutura geral, como mostrarei no capítulo 1. Com isso, no contexto específico da aldeia Kawerêtxikô, onde a tensão entre o tratamento não-indígena e a terapêutica desenvolvida pelos Tapayúna e outros grupos se torna mais visível, penso ser possível falar de uma medicina ocidental, mais pontualmente de uma tradição moderna focada, principalmente, na alopatia.

Ressalto aqui que, quando Dias da Silva trata, na sua tese, especificamente do uso de medicamentos não-indígena pelos Munduruku, mais pontualmente aqueles armazenados no posto-de-saúde, ela usa o termo alopatia ou seus derivados (ibid idem, :66, :67, :129 ou, ainda, :189). Dentro do mesmo contexto, não é sem motivo que os Tapayúna chamam o posto-de-saúde, por vezes, de outro nome: "farmácia". Assim, o termo alopatia pode representar relativamente bem a ideia de que os 
pacientes tratados nos postos-de-saúde, em áreas indígenas ou não, recebem medicações em um "sistema ou método de tratamento em que se empregam remédios que, no organismo, provocam efeitos contrários aos da doença em causa." (Houaiss e Villar, 2009 :100). Por exemplo, para combater as febres das crianças tapayúna, é receitado algum tipo de anti-térmico; para o constante problema de vermes, as técnicas ou enfermeiras administram algum tipo de vermífugo; para a desidratação, soro; para a inconstância do funcionamento intestinal de um antropólogo recémchegado e pouco acostumado à dieta dos Tapayúna, pode-se recorrer à substâncias que tanto 'travam' como estimulam o intestino a funcionar, dependendo do problema que o antropólogo apresentar nas inúmeras vezes que ele procurava ajuda na farmácia.

Todavia, é preciso notar: ao contrário dos transes, das rezas ou das baforações de fumaça do xamã, que quase sempre estão relacionados a uma viagem dele próprio para dimensões diversas em busca de uma identidade ou parte de identidade perdida por aquele que recebe o tratamento ${ }^{10}$, a terapêutica alopática tem como base ou princípio de funcionamento, nas situações citadas, a independência relativa do medicamento frente àquele que está sendo tratado e, também, daquele que ministra o tratamento. Não importa, na maioria dos casos, se o paciente é indígena ou não, homem ou mulher, guerreiro ou ancião: para se fazer uma sutura, a injeção de anestésico deve agir similarmente em todos, aplacando a dor. A penicilina, do mesmo modo, deve dar cabo do agente causador da doença, não importando se ela é aplicada por um médico altamente conhecedor dos seus efeitos ou por um completo leigo ${ }^{11}$. A identidade social do tratado é, por assim dizer, desprezível. É essa característica principal que quero deixar evidente sobre a medicina ocidental, ao menos a que é oferecida no contexto dos postos-de-saúde: a pretensa independência - ou a parcial 'alienação' de tratadores/tratados, para fazer referência a um termo já em desuso nas ciências sociais - das terapias de cura na alopatia moderna, a qual retomarei no capítulo 4, específico sobre a saúde na aldeia Kawerêtxikô. De todo modo, tenho certeza que uma exposição mais complexa e menos determinista pode ser dada à

\footnotetext{
${ }^{10} \mathrm{Na}$ antropologia, a análise mais famosa de um tratamento xamânico é certamente o artigo de LéviStrauss A eficácia simbólica (1975), no qual o autor descreve a viagem de um xamã Cuna para facilitar um parto complicado, comparando esse tratamento com a psicologia moderna.

${ }^{11}$ Não estou colocando em jogo, aqui, o fato de, por exemplo, em caso de existir uma reação adversa, como uma alergia do paciente ao medicamento alopático, o primeiro correr muito menos risco de morte caso receba o tratamento de um especialista. $\mathrm{Na}$ verdade, a reação adversa ou alérgica só corrobora a lógica alopática de que a medicação é de natureza diversa do mal causado - e, alguns casos, tão diversa ou diferente que está no limite da própria aceitação pelo corpo do moribundo.
} 
medicina ocidental e reconheço aqui os limites da presente análise. Contudo, é com essa força ou certeza da alopatia (trazendo resultados contrários daqueles da anomalia e relativamente ignorando tratadores e tratados) que a terapêutica oferecida pelo Estado brasileiro chega aos Tapayúna. É claro que os últimos não aceitam passivamente as submissões típicas desse sistema de cura.

Em relação à categoria de não-indígena, pretendo fazer um movimento contrário ao realizado para a saúde alopática. Em vez de 'afiar' ou delimitar o conceito, pretendo expandi-lo. Assim, abro mão aqui do uso do termo "branco" e seus correlatos e uso, em seu lugar, a expressão não-indígena. Faço esse esforço no intuito de marcar a complexidade e diversidade que está por trás do vocábulo "branco". Mesmo nos limitando à Terra Indígena Capoto Jarinã, esses brancos são múltiplos e têm pouco em comum: funcionários públicos da saúde estatal de origens diversas, como técnicas de saúde, dentistas ou médicos cubanos; professores, diretores de escola, entre outros funcionários da Secretaria de Educação do Estado do Mato Grosso; antropólogos e linguistas em pesquisas de campo acadêmicas; garimpeiros, madeireiros, motoristas de caminhão, fretistas com seus carros de frete, pescadores, agricultores da monocultura extensiva e pequenos produtos rurais; invasores ilegais de todos os tipos, como caçadores, pescadores ou grileiros; transeuntes em ônibus de linha que estão apenas de passagem pela Terra Indígena Capoto Jarinã, viajando para outros locais, etc. Todos esses não-indígenas possuem características físicas, crenças religiosas (ou a negação delas), organizações sócio-históricas e mesmo nacionalidades bastante diversas. A única coisa que parece lhes ser comum, quando tomado como 'pano de fundo' a região da Terra Indígena Capoto Jarinã, é que eles não se identificam como indígenas e, ao mesmo tempo, não são identificados pelos habitantes da referida Terra Indígena como tais - nem tão pouco pelo Estado brasileiro.

Como mostram vários artigos da coletânea organizada por Albert e Ramos (2002), os não-indígenas ocupam uma posição muito peculiar. Eles são um tipo de forasteiro especial, que não se adapta muito bem a qualquer noção indígena de estrangeiro. Essa alteridade estranha representada pelos não-indígenas é objeto de várias estratégias, dos diversos grupos, de "pacificação" ou "domesticação". Assim, na introdução a essa obra, Bruce Albert salienta que os "brancos" possuem: 
uma dimensão de diferença e de virulência até então inédita na suas [indígenas] representações do forasteiro. Os dilemas sócioontológicos suscitados pelo surgimento destes Outros superlativos (mal acomodados entre fantasmas e entidades maléficas, inimigos e afins) alimentaram, assim, com intensidade renovada, as elaborações do "dualismo instável" dos sistemas ameríndios de pensamento e do seu modo de constituição social pela exterioridade, neles desencadeando um processo ampliado de recomposição identitária. (Albert, 2002 :13)

Como já dito, eu próprio fui pré-classificado, em Kawerêtxikô, como um parente afim. Além disso, o contexto de construção de uma identidade Tapayúna nesta última aldeia é bastante complexo e tem paralelos com uma ideia de "domesticação dos não-indígenas", como deixarei claro no desenrolar da tese.

Inicio esta tese com uma discussão sobre educação formal e saúde alopática entre povos indígenas brasileiros. Assim, no capítulo 1, farei um breve histórico do surgimento e desenvolvimento dessas duas áreas entre os não-indígenas no Brasil, com foco na atuação do Estado, assim como uma revisão bibliográfica dos trabalhos acadêmicos sobre ensino formal e saúde alopática entre os indígenas no Brasil. O capítulo 2 abordará a história do contato dos Tapayúna com os não-indígenas e fará uma análise das relações sociológicas entre os povos indígenas que compõem a Terra Indígena Capoto Jarinã. $\mathrm{O}$ capítulo 3 apresentará a etnografia do ensino formal entre os Tapayúna, tomando como foco principal de análise a Escola Goronã. Por fim, o capítulo 4 será dedicado ao estudo da saúde alopática entre os Tapayúna. 


\section{Capítulo 1. A educação e a saúde indígenas em perspectiva: uma breve reconstituição histórica e um panorama dos estudos antropológicos}

As políticas estatais de saúde e educação, em separado, são temas constantes nos estudos antropológicos dos mais diversos grupos humanos no Brasil, indígenas ou não-indígenas. Vários estudiosos tem se preocupado não apenas em entender como tais políticas são produzidas nos níveis governamentais mais abrangentes, mas também em como elas são aplicadas in loco. Há, inclusive, pensadores e linhas de pesquisa que se dedicam quase que exclusivamente a trabalhar um desses dois temas. Existem, assim, espécies de 'nichos' nas ciências humanas no Brasil, que tem como objeto principal entender sociologicamente os processos terapêuticos da medicina ocidental moderna, ou, por outro lado, como se estrutura e opera a educação escolar formal atualmente.

Tendo em vista os dados que recolhi e a diversidade e o volumoso número de estudos produzidos nessas duas grandes áreas, centrarei a minha atenção nos textos que tratam da saúde e educação entre as populações comumente denominadas indígenas, mais especificamente aquelas que se encontram sob a 'égide' do Estado Nacional brasileiro. Na miríade de trabalhos que compõem esses dois campos, minha preocupação é menos direcionada à gestação e aos debates dessas políticas e mais à suas aplicações em campo. Além disso, me debruçarei especialmente sobre os estudos que os linguistas e antropólogos brasileiros produziram, nos últimos anos, sobre esses dois temas. Nesse sentido, estarei menos interessado em fazer um histórico pormenorizado dessa produção acadêmica do que em montar um estado da arte atual para as duas áreas. Esse recorte se justifica pois, como mostrarei adiante, já há reconstruções históricas do debate acadêmico e macro-político muito bem feitas recentemente, tanto para a educação, quanto também para saúde indígenas.

Na organização deste capítulo, antes de discutir a educação e saúde indígenas dentro da antropologia brasileira contemporânea, farei, inicialmente, um breve histórico para mostrar como esses dois temas foram pensados durante o processo de formação do Estado brasileiro. Terminarei este capítulo com uma breve comparação entre educação e saúde indígena na antropologia brasileira. 


\subsection{Uma perspectiva histórica da educação formal e da saúde alopática para os indígenas no Estado brasileiro}

Um texto que ajuda a entender os primórdios da tentativa de imposição de uma educação formal dos autodenominados "civilizados" às populações nativas americanas no que mais tarde seria o Brasil é Como nasce e por onde se desenvolve uma tradição escrita em sociedades de tradição oral?, do linguista da Universidade de Campinas (Unicamp) Wilmar da Rocha D’Angelis (D’Angelis, 2007). Nessa obra o autor argumenta que:

[...] ensinava-se a ler Português e Latim, não Tupi ou Tupinambá. Como se disse, os escritos em Tupi eram para uso dos catequistas. As escolas pretendiam favorecer não a mera aproximação à fé e ao batismo dos índios, mas a formação de quadros indígenas verdadeiramente católicos, para dar seguimento e aprofundamento à missão inaciana. (idem :08)

Havia, portanto, um projeto de educação formal proselitista na aurora do contato entre nativo-americanos e europeus. Em outra obra, o mesmo autor dedica um capítulo inteiro à reconstrução e interpretação do trabalho dos missionários católicos no período colonial. No capítulo II de Aprisionando Sonhos, intitulado "Uma breve história da educação escolar indígena no Brasil", ele reflete sobre o aprendizado de línguas nativas pelos jesuítas da Companhia de Jesus e argumenta que:

Tratava-se apenas de dar resposta a uma situação concreta, em que a presença minoritária portuguesa no litoral não representava estímulo para que os índios aprendessem a língua do colonizador e, sem isso, obrigavam-se os missionários a aprender a língua indígena, para pretender algum sucesso no empreendimento catequético.” (D’Angelis, 2012 :28) 
D’Angelis desconstrói, assim, a vaga idéia de que os missionários católicos, principalmente os da Companhia de Jesus, seriam uma força substancialmente próindígena. É certo que os jesuítas 'defenderam' os nativo-americanos contra as tentativas de escravização dos últimos por produtores rurais - mas somente sob a condição de que os indígenas 'escravizassem' suas mentes ao cristianismo. É típico desse período, portanto, o amálgama entre os projetos civilizatórios e religiosos, peculiar aos esquemas políticos dos Estados Absolutistas da época.

Sem negar o caráter misto dessa tentativa de civilizar os ditos "gentios", o historiador José Ribamar Bessa Freire (2004) matiza com mais cuidado o peso social das línguas gerais. Inicialmente, seu argumento visa justamente desconstruir a existência de uma única língua geral de origem Tupi que abrangesse todo o território colonial. Com isso, o autor identifica ao menos duas línguas gerais, usada por nativos e europeus: a LGA (Língua Geral Amazônica) e a LGP (Língua Geral Paulista) (idem :31). Resenhando um importante artigo de José Honório Rodrigues, Freire faz referência a um conjunto de línguas gerais diferentes também entre os escravos de origem africana (ibid idem :35). Ponderando sobre o monolinguismo da maioria da população brasileira nos dias atuais, ele postula que:

A supremacia do português no Brasil foi resultado de um processo longo e conflituoso, que se desenvolveu durante todo o período colonial, de forma desigual nas diferentes regiões do país. O trabalho desses linguistas consistiu em demonstrar que a implantação do português em terras americanas ocorreu em contato com muitas línguas indígenas, produzindo situações lingüísticas caracterizadas pelo desenvolvimento de línguas gerais, entre as quais a língua geral paulista e a língua geral amazônica. (ibid idem :38)

Tratando do período imediatamente posterior à expulsão dos jesuítas da Colônia Americana, Rita Heloísa de Almeida, na obra $O$ Diretório dos índios: um projeto de "civilização" no Brasil do século XVIII (Almeida, 1997) também descreveu o projeto colonial de civilização dos nativo-americanos. Elaborado em 1755 e vigente até 1798, o Diretório dos índios era um código legal positivo 
diretamente ditado pelo monarca absolutista aos seus súditos no Novo Mundo. Implementado pelo Marquês de Pombal para acelerar a incorporação das populações indígenas à sociedade colonial, ele preconizava, entre outras medidas, o ensino do Português, o fim dos aldeamentos, que deviam se tornar vilas sob administração de um diretor, e a transformação do índio em trabalhador. O norte da política colonial portuguesa era, assim, deixar de lado a mediação que faziam os jesuítas e tratar mais diretamente de seus interesses coloniais na América. Almeida descreveu o processo de conquista e submissão dos povos americanos como "graduações de um processo de aniquilamento da soberania do vencido dentro de uma lógica em que seu conquistador tem um propósito de preservação física." (idem :29).

É necessário esclarecer que esse "propósito de preservação física", dentro da história colonial brasileira, não era o mesmo, nesse momento, para índios e negros africanos. A população sequestrada na África e compulsoriamente transformada em escravos era tratada em um grau tão mais baixo de humanidade pelos colonizadores que sua escravização só foi abolida, ao menos juridicamente, um ano antes da Proclamação da República, em 1888. Assim, em $O$ Diretório, pode-se notar que, enquanto a tentativa da metrópole foi a de englobar os indígenas como "súditos", como "número" ou "população" (ibid idem :44), os negros nunca seriam referenciados, na história colonial, nessas categorias, sendo tratados legalmente como mão-de-obra compulsória e, em algumas situações, até mesmo descartável. Pode-se conferir, por exemplo, o tratamento dado por um senhor de escravos na Colônia Portuguesa da América em 1591, ano da primeira visitação da Inquisição Portuguesa à Colônia (Vainfas, 1997). Sua escrava, uma jovem mulher negra, foi jogada grávida e ainda viva em uma fornalha, por ordem de seu senhor, para servir de exemplo aos outros escravos recalcitrantes (idem, Confissão n. 06 de Fernão Cabral de Taíde).

Aos índios, contudo, dever-se-ia, com o advento de uma lei geral que os tutelasse para fora da sociabilidade das reduções jesuíticas, torná-los súditos da Coroa Portuguesa. Isto se daria, teoricamente, no mesmo nível que os portugueses advindos da Península Ibérica. Como mostra Almeida, com a expulsão dos jesuítas e a vigência do Diretório, a ideia geral era transformar as aldeias do Novo Mundo em cidades no modelo vivido pelos portugueses no Velho Continente.

Não é difícil notar, portanto, que mesmo com a substituição das reduções jesuíticas por um código legal diretamente ditado pelo monarca absolutista, o que se 
objetivava não era somente tirar a população nativa da condição de pretensa servidão/escravidão que tais grupos viviam nas reduções jesuítas ou nas fazendas dos laicos, mas sim torná-los esmerados súditos da Coroa Portuguesa. Deveriam, se ainda não o tivessem feito, deixar de lado suas crenças pagãs e adotar o cristianismo católico; deveriam parar de falar as Língua Gerais; deveriam aprender o Português; e, principalmente, suas aldeias e outros povoamentos deveriam se tornar, como já dito, vilas e, mais tarde, cidades no modelo pensado como civilizado dos europeus ocidentais (Almeida ibid idem).

Havia, assim, um efetivo problema de ocupação populacional das terras conquistadas ou que se pretendia conquistar, para ser mais exato. Os europeus degredados ${ }^{12}$ e os investidores que vinham não-compulsoriamente colonizar as ditas possessões da Coroa Lusitana no Novo Mundo não eram suficientes para garantir a referida posse. Com isso, havia a necessidade de converter os nativos em súditos e não escravizá-los diretamente, como acertadamente argumenta Nádia Farage em $A s$ muralhas do sertão (Farage, 1991). Não há como negar que, para isso, a educação formal, ainda de cunho católico, mas agora não mais sobre a responsabilidade dos jesuítas, era pensada como um dos agentes da mudança que deveria ser empreendida às populações nativas na América ${ }^{13}$.

No mesmo mote que Nádia Farage e Rita Heloísa de Almeida, mas trabalhando com um projeto de Brasil do monarquista José Bonifácio várias décadas depois do Diretório, já no século XIX, Alcida Rita Ramos (2000) identificou a mesma gana integracionista e subjugadora. Assim, para a autora:

Um dos aspectos mais vívidos do diretório e presente no Projeto de José Bonifácio é o repúdio ao isolamento que ambos atribuem à política indigenista dos jesuítas. Tanto o diretório como o projeto

\footnotetext{
${ }^{12}$ Para uma excelente análise do degredo no Período Colonial brasileiro, conferir a obra Os excluídos do Reino: a Inquisição portuguêsa e o degredo para o Brasil-Colônia (Pieroni, 2000). Um dos maiores 'crimes' cometidos pelos súditos portugueses que eram degredados ao Brasil era a acusação de criptojudaísmo, ou seja, de não terem verdadeiramente se convertido ao cristianismo e praticarem o judaísmo clandestinamente.

13 Apesar da expulsão dos jesuítas, outras ordens católicas foram chamadas para ajudar no empreendimento colonizador português e, mais tarde, no Império Brasileiro. Falando já na época do $2^{\circ}$ Reinado do Brasil Imperial, Marta Rosa Amoroso argumenta que: "Ao Estado cumpria dar apoio estratégico, incluindo a manutenção do aparato militar (os empreendimentos geralmente eram precedidos pela montagem de colônias militares ou presídios) e financeiro para os aldeamentos indígenas, a maioria deles administrada pelo missionário religioso.” (Amoroso, 1998 :102).
} 
são veementes em advogar a integração dos índios à sociedade colonial, no caso do diretório, e nacional, no caso do projeto de José Bonifácio. (idem :273)

Em outra passagem do mesmo artigo, a autora argumenta que os negros, então ainda na condição de escravos, eram tidos em mais baixa conta que os índios, sendo considerados, no projeto de Brasil de Bonifácio, como "vis e corrompíveis" (ibid idem $: 270)$.

Assim, como dito acima, o projeto colonizador alinhava os nativos americanos aos portugueses, ambos sendo tratados, ao menos na letra da lei, como igualmente submetidos ao monarca absolutista. Ambos eram considerados "súditos" da Coroa. Essa potencialidade de equivalência político-legal entre os "selvagens" e os "cristãos" abriu espaço para o desenvolvimento de uma outra equivalência: a dos corpos e, consequentemente, da terapêutica que irá curá-los dos pecados/doenças que sobre eles se afligirem.

No período colonial brasileiro, a saúde não-indígena estava, como a educação, sob o jugo do Estado absolutista e, portanto, da religiosidade católica. Contudo, a educação parece ter se emancipado como uma esfera relativamente autônoma antes do controle restrito da saúde dos corpos humanos que podemos notar nos dias atuais.

Claude Lévi-Strauss lembra do domínio e, mais que isso, da obrigatoriedade do ensino e aprendizado da escrita como um fenômeno sociológico que "acompanhou fielmente a formação das cidades e dos impérios, isto é, a integração num sistema político de um número considerável de indivíduos e sua hierarquização em castas e em classes" (Lévi-Strauss, 1996, :283). Assim, a sistematização da qual dependeu a medicina moderna só foi possível depois que os indivíduos foram inseridos em um sistema universalizante de educação formal financiado ou não pelo Estado.

A necessidade dessa gradual formalização da educação se desenvolveu ao longo da história, como mostram os estudos acima mencionados de Wilmar de Rocha D’Angelis, José Ribamar Bessa Freire, Nádia Farage, Rita Heloísa de Almeida e Alcida Rita Ramos. Antes de implementar uma escola de medicina, o Estado colonial precisava unificar a língua falada na colônia americana, extirpando a diversidade original e impondo o Português nas áreas de influência mais direta da Coroa. Além 
disso, o Estado colonial português também precisava estabelecer uma escola de educação formal básica com um sistema de avaliação do aprendizado dos estudantes.

Deste modo, a educação básica obrigatória deu as bases para que se pudesse cobrar de todos a consciência e o respeito à lei positivada, ou seja, sedimentada em códigos escritos. Assim, o conhecimento médico, entre outros, é ensinado, organizado e, em certo sentido, exercido tendo como base a obrigatoriedade da educação formal. Ele é um produto do sistema educacional. Esse argumento geral poderia justificar, de início, o tratamento conjunto que dou, na presente pesquisa, às áreas de saúde e educação.

Não há espaço aqui para se fazer um apanhado, ainda que não minucioso, do desenvolvimento do saber e poder médico ou da "clínica médica" (Foucault, 2008). Ressalto apenas que há autores que trataram pontualmente do desenvolvimento da medicina, sejam eles especialistas de dentro do campo (Friedman e Fredland, 2006, Portman, 2008 ou Gordon, 1996) ou de fora (Foucault, idem). O que me interessa mais particularmente é o resultado direto desse longo processo histórico de desenvolvimento da terapêutica ocidental dos corpos em geral. Nesse processo, a medicina se tornou cada vez mais independente do cristianismo. Para os especialistas da medicina, a religião era simplesmente uma crença que variava conforme as sociedades e culturas e que deveria ser banida dos estudos da ciência do qual faria parte a medicina. Para eles, o cristianismo, portanto, não trataria de temas realmente absolutos e universais, como os corpos humanos dentro da terapêutica médica, sendo apenas um exemplo efêmero de um pensamento pré-científico de determinado grupo humano - ainda que fosse o mesmo grupo humano a desenvolver o método científico.

Nesse sentido, tanto os códigos legais absolutistas como também seus sucessores republicanos ${ }^{14}$ sempre tipificaram muito especificamente aqueles que poderiam exercer essa terapêutica - e, consequentemente, criminalizaram aqueles que não tinham condições (dadas inicialmente pela educação formal, diga-se de passagem) de desempenhá-las. Veremos um exemplo claro da luta política de quem

\footnotetext{
${ }^{14}$ Conferir, para o caso brasileiro de construção de uma república, o estudo clássico de Emília Viotti (1999), mais focado na conjuntura política e econômica que deu origem à República Velha; ou, ainda, a análise menos conhecida, mas também bastante interessante, de Ana Luísa Martins (1990), mais interessada na propaganda republicana que deslegitimava gradualmente o Império de Pedro II como arcaico e ultrapassado.
} 
pode ou não adentrar ou tratar os corpos humanos ainda no presente capítulo, quando tratarei do Ato Médico.

No final do século XIX e começo do século XX, os indígenas deixaram de ser referidos como potenciais "súditos" e passaram, ao menos na letra da lei, a compor os "cidadãos" de um novo sistema político: a República virtualmente laica e positivista. Também no campo das potencialidades, a população negra, ex-escrava, passou a poder almejar a mesma categoria política. Assim, houve uma ampliação dos corpos que podiam ser, ao menos teoricamente, homogeneizados pelo Estado, pela educação formal e pela medicina científica.

Nesse processo gradual de laicização, quero sublinhar o projeto da quimérica universalização ou capilarização das ações do Estado brasileiro. A maioria do território pretensamente classificado como "nacional" na $1^{\text {a }}$ República brasileira, principalmente do interior, ainda estava sob o controle, de fato, dos povos indígenas. Apesar de um projeto específico de nação a ser levado aos mais distantes rincões do que se considerava o território brasileiro, tal proposta não foi realizada, de fato, durante a chamada República Velha e boa parte das "Muralhas dos Sertões" (Farage, op. cit.) do período colonial ainda se encontrava de pé.

Em seu estudo sobre o Serviço de Proteção aos Índios e Localização de Trabalhadores Nacionais - SPI/LTN, órgão indigenista criado durante a $1^{\text {a }}$ República para ensaiar um domínio "pacífico" e "nacional" dos índios, o antropólogo Antônio Carlos de Souza Lima mostrou como a noção de tutela indígena foi essencial para marcar a relativa incapacidade jurídica dos índios e suas conseqüências até os dias de hoje nas diferentes políticas públicas (Souza Lima, 1995). Nesse sentido, a ação tutelar sobre índios, crianças, mulheres, loucos, entre outros, é fundamental na formação da noção de um Estado brasileiro independente e, agora, nacional.

A "integração" do território, a "ocupação" dos ditos "vazios populacionais" não era um grande problema, de fato, durante a chamada República Velha, mais interessada em manter os preços internacionais do café do que em cumprir efetivamente seu projeto integrador positivista. Contudo, será um dos nortes do governo autoritário de Getúlio Vargas. Tratarei mais pontualmente da chamada "Marcha para o Oeste" no próximo capítulo da presente tese, mas adianto aqui que a colonização da região tradicional dos Tapayúna se deu justamente nesse ímpeto de ocupar os ditos "vazios populacionais". 
Esses "vazios" estavam, obviamente, já habitados por diversas populações indígenas e é a partir desse momento, depois da Revolução de 1930, que se começa a colocar em prática o projeto de tutela em todo o território do que se considerava o Estado brasileiro (idem) - categoria ainda atualmente tão polêmica no indigenismo e no movimento indígena. De toda forma, entramos, a partir da década de 1930, no período de um desenvolvimento autoritário ou a qualquer custo, um tempo que os diversos desdobramentos atuais parecem não ter conseguido superar completamente.

Assim, ao longo da segunda metade do século XX, cresceu gradualmente a pressão para uma política que promovesse a integração das populações nativas à chamada "comunhão nacional" e à "modernidade"15. A "civilização"16 da população pretensamente bárbara deu o norte das políticas republicanas voltadas aos indígenas, tomando o lugar do cristianismo católico nos períodos coloniais e absolutistas.

Cabe lembrar que o primeiro Ministério da Educação no Brasil se deu após a vitória dos dissidentes na Revolução de $1930^{17}$, que pôs fim à República Velha e trouxe inovações ao sistema representativo no Brasil, como o voto feminino - uma nova ampliação nos corpos políticos - e um projeto de educação pública universal. Criado em 1953, por decreto do presidente Getúlio Vargas, agora eleito, o primeiro Ministério da Saúde, por sua vez, foi um desdobramento do Ministério da Educação. ${ }^{18}$ As duas pastas, desde então, nunca mais deixaram de compor a organização da República brasileira, até os conturbados dias políticos de hoje. O ideal integracionista perdurou durante a última ditadura militar e permaneceu, na letra da lei, ao menos até a Constituição de 1988.

\footnotetext{
${ }^{15}$ É claro que esse projeto modernizador não estava restrito aos indígenas: os brasileiros, de maneira geral, deviam se modernizar e o Brasil, como todo, devia entrar em uma era de desenvolvimento industrial. Assim, inicialmente sem abandonar por completo as políticas de proteção dos preços do café, Vargas teve condições políticas e econômicas para, gradualmente, substituir as importações de produtos industrializados por uma indústria nacional durante a II Guerra Mundial, diversificando, portanto, a base econômica do país.

${ }^{16}$ Não é minha intenção empreender um levantamento, ainda que não-minucioso, dos ideais de civilidade. Lembro, apenas, que autores como Norbert Elias (1993a e 1993b) mostram como a construção da noção de Estado está eivada de um processo civilizador de longuíssima duração, que remonta aos manuais de etiqueta do fim do período medieval e se desdobra até hoje. Para citar apenas uma definição divergente de civilidade, que não está baseada na inovação tecnológica ou no rebuscamento das convenções, cito a polêmica anarquista Emma Goldman, no início da década de 40: "Correr a 150 quilômetros por hora não é prova de civilização [...] Socialmente falando, a civilização e a cultura devem ser medidas pelo grau de liberdade e pelas possibilidades econômicas que goza o indivíduo; [...] pela ausência de castas privilegiadas; por uma vontade de liberdade e dignidade humanas. Em resumo, o critério de civilização é o grau de emancipação real do indivíduo.” (2007 :41) https://cpdoc.fgv.br/producao/dossies/AEraVargas1/anos3037/IntelectuaisEstado/MinisterioEducacao, com acesso em 30/01/16

${ }^{18} \mathrm{http} / / /$ portalsaude.saude.gov.br/index.php/o-ministerio/historico, com acesso em 30/01/16.
} 
Na Assembléia Nacional Constituinte de 1987-88, houve grande mobilização para mudar o tratamento que era historicamente dado aos povos indígenas nos códigos legais. Embora não tenha conseguido dar cabo do desenvolvimentismo autoritário das décadas anteriores ${ }^{19}$, o movimento pela redemocratização do país foi um importante marco na crítica contemporânea à noção da tutela indígena. $\mathrm{O}$ ideal de "integração" e "civilização" da população nativa, como esboçados acima, sofreram, ao menos nos termos estritos da lei positivada no nível federal, uma importante crítica. Este estremecimento se deu, primeiramente, por causa da pressão política do movimento indígena organizado, como relembra Rosana Lacerda em um estudo específico sobre a Assembléia Nacional Constituinte (Lacerda, 2008). Secundariamente, pelo movimento indigenista daqueles que, apesar de não-indígenas, atuavam e ainda atuam a favor desses povos.

Assim, a atual Constituição brasileira possui um capítulo inteiro dedicado aos índios (VIII). Nesse capítulo, se destaca o artigo 231: "são reconhecidos aos índios sua organização social, costumes, línguas, crenças e tradições, e os direitos originários sobre as terras que tradicionalmente ocupam, competindo à União demarcá-las, proteger e fazer respeitar todos os seus bens." Além disso, ficou garantido, de maneira imprescritível, o direito à terra, seus recursos e possíveis lucros advindos da sua exploração. Já o artigo 232 afirma que: "os índios, suas comunidades e organizações são partes legítimas para ingressar em juízo em defesa de seus direitos e interesses, intervindo o Ministério Público em todos os atos do processo." ${ }^{20}$

Apesar das disposições progressistas da Constituição, o Estatuto do Índio de 1973 nunca foi legalmente revogado. Criado durante o Regime Militar, ele continua sendo usado pelo judiciário brasileiro contemporâneo, além de outras instituições, como a própria Funai, para classificar, em determinadas situações específicas, certas etnias indígenas no Brasil como tuteladas. Temos, assim, uma brecha dada pela nãoregulamentação efetiva do princípio federal de independência e liberdade lingüística/cultural dos povos nativo-americanos no país a partir da última Carta Magna.

Cabe notar, também, que algumas lideranças indígenas percebem vantagens relativas no Estatuto do Índio e não o avaliam como totalmente negativo. Antonio

\footnotetext{
${ }^{19}$ Conferir, por exemplo, a maneira como foi levado a cabo a construção da hidrelétrica de Belo Monte, que deve começar a operar ainda no atual ano de 2016.

${ }^{20} \mathrm{Http}$ ://www.planalto.gov.br/ccivil_03/Constituicao/Constituicao.htm, com acesso em 28/09/16.
} 
Carlos de Souza Lima (2014) publicou uma interessante análise sobre a ação do poder tutelar e sua influência na vida daqueles classificados pelo Estado como indígenas e, assim, potencialmente tuteláveis. Ao se referir às vantagens relativas que a tutela tem para alguns grupos, o autor argumenta que:

Estar assim representado significa que, pela mediação e sob o controle parcial desse outro - um órgão governamental, uma organização não governamental (ONG), uma ordem missionária, cientistas de universidades - coletividades como as indígenas e outras acessam recursos muito superiores aos que obteriam sem o tutor - o que é particularmente claro no caso de certos povos ligados a redes de relações muito assentadas dentro da Funai. (idem :29)

A ação tutelar não passa apenas pela letra positivada da lei, mas certamente também por uma tradição e saber fazer historicamente introjetados e disseminados dentro das instituições indigenistas, diretamente ligadas ou não ao aparato público do Estado brasileiro. Assim, vários experientes funcionários do já extinto Serviço de Proteção aos Índios (SPI) migraram para a Fundação Nacional do Índio (Funai) e levaram com eles suas antigas práticas tutelares. O autor diz, inclusive, que alguns desses funcionários não tinham sequer a formação escolar necessária para ocupar cargos importantes dentro da nova estrutura e passaram, assim, por cursos formais, já que a eles faltava "o ensino médio completo, exigência que se deveria cumprir para ascender ao cargo de técnico de indigenismo." (ibid idem :47).

Para finalizar esse breve levantamento histórico, é importante notar que os últimos governos da chamada recente democracia brasileira trouxeram diversas inovações nos campos da educação formal e da saúde alopática oferecidas aos indígenas pelo poder público em território nacional. No entanto, nenhum deles, como ficará claro nos próximos subtópicos, conseguiu efetivamente acabar com a tradição proselitista que remonta o século XVI, extirpar da ação estatal o seu viés tutelar ou ainda fazer com que a educação e a terapêutica de saúde oferecida aos povos indígenas fossem completamente respeitadoras das diferenças socioculturais. 
De todo modo, a demarcação dos territórios indígenas, talvez a principal reivindicação desses povos nas últimas décadas, vem se fundamentando legalmente. Apesar da diversidade de situações, foram criadas grandes áreas contíguas, destinadas aos povos indígenas, a exemplo do próprio Parque Indígena do Xingu no qual vivem os Tapayúna, como descreverei no próximo capítulo. Além disso, criou-se instituições públicas de caráter fiscalizador que tem realmente advogado a favor de condições de vida minimamente satisfatórias para os diversos povos indígenas no Brasil, como o Ministério Público Federal, mais pontualmente a $6^{\mathrm{a}}$ Câmara de Coordenação e Revisão, que assessora juridicamente os indígenas e outras populações ditas "tradicionais" em importantes refregas judiciais.

Nas duas última décadas, a Funai perdeu progressivamente, ou pelo menos deixou de controlar, muitas de suas antigas prerrogativas como a educação formal e a saúde alopática. A primeira passou a ser responsabilidade do Ministério da Educação (MEC) e viveu um processo gradual de estadualização e municipalização das escolas indígenas - processo que, veremos, deu origem à escola de educação formal da aldeia Kawerêtxikô dos Tapayúna. A alopatia pública oferecida aos indígenas, por sua vez, foi também transferida para seu respectivo órgão do Executivo Federal: o Ministério da Saúde (MS). Contudo, nesse último campo, criou-se um subsistema de saúde para os indígenas legalmente subordinado ao Sistema Único de Saúde (SUS) - e não uma municipalização e estadualização das ações, como se deu na área da educação formal indígena.

Nesse novo arranjo da saúde alopática, criaram-se "distritos", mas eles não se confundem com os municípios dentro da organização política do Estado brasileiro. Assim, em 2010 foi criada a Secretaria Especial de Saúde Indígena (SESAI), órgão subordinado ao SUS e responsável, de maneira geral, pela terapêutica alopática entre os povos indígenas. O primeiro Distrito Sanitário Especial Indígena (DSEI), unidade básica de ação da alopatia pública para os indígenas em nível regional, foi criado entre os Yanomami no ano 2000, com a assessoria da organização não-governamental Comissão Pró-Yanomami (CCPY).

Essa criação ocorreu depois da repercussão internacional extremamente negativa do livro Darkness in El Dorado, do jornalista estadunidense Patrick Tierney. Nessa obra, também publicada no ano 2000, o autor denuncia o uso dos Yanomami como "cobaias de laboratório" para experiências de cientistas na vacinação de grupos 
humanos relativamente isolados ${ }^{21}$. Hoje, ao todo, são 34 DSEIs, espalhados por todo o Brasil, todos ocupados com, pelo menos, uma Equipe Multidisciplinar de Saúde Indígena (EMSI) $)^{22}$.

O mais importante a ser notado é que, apesar das diferenças, as duas políticas públicas de educação e saúde alopática indígenas são, ao menos teoricamente, diretamente inspiradas no texto constitucional de 1988. Deste modo, ambas pretendem-se respeitadoras das diferenças socioculturais desses povos - ao menos isso é o que consta nos textos que pretensamente regem tais políticas. Por exemplo, o Referencial Curricular Nacional para as Escolas Indígenas (RCNE/Indígena), lançado em 1998, diz que a educação formal oferecida a tais povos deve ser "intercultural, comunitária, específica e diferenciada" (MEC, 1998 :24). Já na terapêutica alopática, a página eletrônica da SESAI advoga que sua política será colocada em prática "respeitando as especificidades culturais e o perfil epidemiológico de cada povo." 23

\subsection{Os estudos sobre educação formal indígena na antropologia brasileira}

À luz da Constituição Federal de 1988, o Estado brasileiro procurou, ao menos em suas ações no nível federal, promover um novo paradigma para a educação escolar indígena. Segundo a atual legislação, esse novo paradigma deve levar em consideração as especificidades culturais de cada povo indígena tanto na transmissão dos conteúdos como na elaboração e gestão das políticas educacionais. No rastro das mudanças legais, os textos que se debruçam sobre a questão da educação escolar indígena proliferaram nos últimos anos e diversos antropólogos passaram a apresentar análises da influência da nova Carta Magna na educação escolar oferecida aos povos indígenas em território brasileiro. Assim, encontramos uma grande diversidade de obras que tratam dessa temática: publicações em revistas especializadas, livros,

\footnotetext{
${ }^{21}$ Para maiores informações sobre o caso, conferir a publicação da CCPY: Research and ethics: the Yanomami case. Brazilian contributions to the Darkness in El Dorado controversy. (CCPY, 2001).

${ }^{22}$ Informações conseguidas na página eletrônica do MS: http://portalsaude.saude.gov.br/index.php/oministerio/principal/secretarias/secretaria-sesai, com acessos em 21/09/2016.

23 Informações conseguidas na página eletrônica do MS: http://portalsaude.saude.gov.br/index.php/conheca-a-secretaria-sesai, com acesso em 22/09/2016.
} 
coletâneas, teses, dissertações, etc. Os temas abordados também são extremamente variados: sistematizações de códigos legais, pesquisas em arquivos públicos e privados, críticas da legislação pública em vigor, etnografias baseadas em trabalho de campo com determinado povo indígena, discussões teóricas sobre as tensões entre oralidade e escrita, entre outros temas.

Assim, a ideia de uma escola entendida como "diferenciada" passou a ser debatida por muitos autores que pretendem analisar a implementação das atuais políticas de educação formal para os povos indígenas. Todos esses autores ancoram suas análises a partir da possibilidade legal aberta com a Carta Magna de 1988 para uma educação escolar diferenciada para os povos indígenas. Eles refletem sobre uma escola baseada na adoção de certos princípios, como o uso da língua nativa ou métodos/conteúdos educativos localmente e culturalmente contextualizados, que transformaria a educação para os índios, característica de uma época anterior, em uma educação propriamente indígena nos tempos atuais.

Análises sobre essas mudanças podem ser encontradas em uma grande variedade de trabalhos, como Betty Mindlin (2004), Mariana Paladino e Nina Paiva Almeida (2012), Aracy Lopes da Silva e Mariana Kawall Ferreira (2001), Lux Boelitz Vidal (2001), Isabele Vidal Giannini (2001), Cássio Noronha Inglez de Sousa (2001), Iara Ferraz (2001), Maria Amélia Reis Silva e Andrés Pablo Salanova (2001), Eliane Camargo e Célia Nhii (2001). Na impossibilidade de abordar cada um desses trabalhos, optei por selecionar autores cujas idéias me ajudaram a entender diretamente o contexto etnográfico dos Tapayúna. Antes de mencionar casos etnográficos específicos, começarei por uma análise mais geral sobre a temática da educação formal indígena, principalmente pelo trabalho de Luís Donisete Benzi Grupioni (2008) que, em razão de sua abrangência, oferece um excelente panorama do tema.

Em sua tese de doutorado, Grupioni (2008) fez um cuidadoso histórico do aporte legal dado à educação formal indígena no Brasil, com foco principal nas políticas públicas de educação formal para as populações nativo-americanas, mostrando como elas foram gestadas, no Brasil, até a promulgação da Constituição de 1988 - e as inovações que resultaram da nova Carta Magna. O norte geral da análise do autor também pode ser encontrado em trabalhos anteriores e posteriores, como nos estudos de Paladino e Almeida (2012), Lopes da Silva (2001b) ou Ladeira (2004), 
mas, como afirma Grupioni, "poucos são os trabalhos comparativos e, em menor número ainda, os que buscam uma abordagem mais ampla." (idem :21).

A análise geral feita por Grupioni sobre a qualidade do ensino oferecido pelo Estado brasileiro aos povos indígena após a Constituição de 1988 não é nada animadora. Apesar dos avanços na educação formal indígena nos textos legais, ainda se está longe da implantação efetiva de uma rede de escolas que respeitem a alteridade de cada grupo indígena - as chamadas escolas diferenciadas. O autor chega à conclusão que, no Brasil, há "uma empobrecida grade curricular e cada vez menos ancorada nas especificidades dos grupos envolvidos" (idem:175). Para ele, "sem um novo formato, proposto e executado pelos professores indígenas e suas comunidades, a educação diferenciada continuará refém do formato imposto pela política pública" (idem: 214).

A tese de Grupioni também traz informações interessantes sobre o processo de estadualização e municipalização das escolas indígenas que ajudam a entender o contexto regional no qual estão inseridos os Tapayúna. Assim, o estado do Mato Grosso viveu um forte processo de estadualização das escolas indígenas nos últimos anos. As escolas indígenas que estavam, anteriormente, sob a responsabilidade da Funai ou de outras instituições, passaram para o controle direto da Secretaria Estadual de Educação do Mato Grosso. Em 1999, existiam no estado 16 escolas indígenas municipais e 129 estaduais. Já em 2005, as municipais eram 26 e as estaduais somavam 150 (ibid idem, :129). Em 2006, com 182 escolas indígenas, o Mato Grosso tinha o segundo maior número de escolas indígenas estaduais do país, perdendo somente para Roraima com 253 escolas na mesma época (ibid idem :127).

Esses dados confirmam essa gradual retirada de responsabilidades - e, consequentemente, também de orçamento e pessoal - do órgão indigenista federal e a passagem de responsabilidades para o Ministério da Educação. Esse foi o processo que deu origem à criação da Escola Estadual Goronã dos Tapayúna que a análise macro-política e histórica feita por Grupioni nos ajuda a compreender. Para fundar a sua escola, os Tapayúna tiveram que negociar politicamente com os responsáveis pela educação em Cuiabá e com o município de Peixoto de Azevedo (MT) - e não com os servidores da Funai, como teria sido se a Escola Goronã tivesse sido fundada décadas atrás. 
Em um artigo de 2004, Maria Elisa Ladeira já sinalizava alguns dos problemas levantados por Grupioni. Para ela, a dificuldade do respeito ao texto constitucional não se restringia à questão da educação pública e dever-se-ia repensar "como o Estado nacional deve definir sua relação com os povos indígenas. (Ladeira 2004 :150)". Além disso, no mesmo artigo, a autora considerava que a estadualização ou municipalização das escolas indígenas tornava mais difícil as cobranças políticas por parte das organizações indígenas, já que antes as demandas eram todas dirigidas ao órgão indigenista federal. Com o referido processo, os povos indígenas passaram a ter que reivindicar seus direitos em instâncias com as quais não tinham, tradicionalmente, uma relação direta (ibid idem :154, nota 5). As mesmas observações podem ser estendidas para a saúde alopática e sua transferência para o Ministério da Saúde.

É importante discutir o que se entende com a expressão: “escola indígena diferenciada". Apesar de mostrar uma situação concreta pouco animadora, Grupioni não deixa de ressaltar que a atual democracia, respaldada pela Constituição de 1988, abre uma importante possibilidade legal para um tratamento das sociedades nativas que não passe pelo senso-comum de que elas estariam fadadas à 'fagocitação' pela civilização brasileira - ou à cristianização por um Estado Absolutista. Nesse sentido, o autor defende que um dos papéis da educação formal diferenciada para os povos indígenas deve ser a defesa das tradições nativas dentro do próprio ambiente escolar. Segundo ele, "se antes os índios enunciaram sua cultura para se posicionar contra a escola assimiladora, agora, ao contrário, é a escola diferenciada que se torna o lugar, por excelência, para realizar a defesa dessa cultura." (:194). No entanto, é importante deixar claro que esse não é o único objetivo da educação formal indígena e, como veremos, não é o principal, pelo menos entre os Tapayúna e entre vários outros povos.

A educação formal indígena também não deve ser simplesmente uma adaptação superficial da escola tradicional às novas aspirações de respeito à alteridade contidas na legislação, não tendo impacto maior na melhoria do sistema educacional formal para os índios. Antonella Tassinari traz reflexões interessantes sobre esse tema:

[...] principalmente a respeito de grupos indígenas com antigas experiências de ensino escolar, não é possível definir a escola de maneira totalmente alheia. Por outro lado, também não se 
pode compreendê-la como completamente inserida na cultura e no modo de vida indígena. Ela é como uma porta aberta para outras tradições de conhecimentos, por onde entram novidades que são usadas e compreendidas de formas variadas. (Tassinari, 2001a, :50)

Assim, sem negar o caráter de frente civilizacional do aparato educacional que gerencia os espaços de povos conquistados, como o histórico no início do presente capítulo apresentou, Tassinari vê a escola indígena como um "espaço de fronteira" no qual também existe um "outro lado da moeda, o lado da agência e de suas formas de reordenar a experiência escolar e de reinterpretar os conhecimentos advindos com a escola." (idem, :58). O enfoque construído por essa autora considera a escola como um espaço para dar conta da alteridade, para entender e usar efetivamente conhecimentos e técnicas não-indígenas para construir relações menos assimétricas dos índios com a sociedade nacional.

Chegamos aqui ao ponto central para a presente tese do debate sobre a educação formal indígena. Por um lado, a escola indígena pode servir como uma espécie de reflorescimento sociocultural, trabalhando, por exemplo, uma língua já em desuso, estimulando ou reinventando rituais e práticas nativas. Por outro, como é o caso entre vários povos indígenas e também entre os Tapayúna, a escola tem por incumbência última traçar relações menos assimétricas entre indígenas e nãoindígenas, justamente através do aprendizado e uso, pelos primeiros, de técnicas como o letramento ou os cálculos matemáticos dos últimos. Wilmar da Rocha D’Angelis alertou para os riscos de se reduzir a educação escolar indígena ao simples processo de valorização das culturas nativas. Segundo esse autor:

as evidências - muitas - estão mostrando que a "etno-escola" é, em última análise, uma "escola adaptada", refletida nos seus currículos "diferenciadores". Na maior parte dos casos, tratase de uma escola ornada com o folclore da "cultura"." (D’Angelis, $2012: 78$ ) 
De todo modo, é importante frisar que ver a escola como "espaço de fronteira" não significa esquecer as assimetrias de poder e ignorar o fato que as relações entre esses "dois lados da moeda" são profundamente desiguais. Em uma crítica ao conceito de escola como "fronteira", Andrea Lisset Pérez fez uma alerta crucial contra tal perigo:

De um lado, a noção de escola como um lugar de "trânsito, articulação e troca de conhecimentos" parece reduzir a reflexão a um só elemento: o cognitivo. Ainda que seja esta a "natureza" estipulada para a educação escolarizada, considero que a escola ou qualquer outro espaço social, cuja finalidade seja socializar a criança, deveria contemplar as múltiplas e diversas dimensões que esse processo inclui, como os valores, os hábitos, os comportamentos, as práticas, as relações, as afetividades, as habilidades, etc. (...) Apesar de o conceito de fronteira permitir o entendimento dos fluxos culturais, também leva implícito um sentido equidistante entre índios e não-índios, despolitizando, em certo sentido, a natureza dessa relação. Ainda que não se negue, de alguma maneira se ocultam as hierarquias e as configurações de poder ali presentes. Um poder que regula e controla a forma, os ritmos, os conteúdos e os resultados esperados no processo de aprendizagem. Assim, esse "trânsito de conhecimentos" não se produz em equidade de condições, está mediado pelo ideal ou modelo educativo subjacente a esse conjunto de dispositivos colocados em jogo no espaço escolar. (Pérez, $2007: 236)$

Nos últimos anos, várias etnografias analisaram o processo de implementação das políticas de educação escolar indígena em povos específicos e procuram desvendar a visão dos índios sobre a escola. Esses trabalhos revelam as dificuldades encontradas para concretizar os ideias constitucionais das políticas educacionais e a importância da escola para dominar os instrumentos do mundo não-indígena. Alguns 
exemplos nos ajudarão a entender melhor a noção de escola indígena diferenciada e seus desafios.

João Marcelo de Oliveira Macena realizou uma etnografia sobre a educação formal entre os Canela do Maranhão (Macena, 2007). Como os Tapayúna, os Canela possuem uma escola pública que é regida pela secretaria estadual de educação. Idealmente, a escola canela é orientada pelos novos princípios constitucionais. No entanto, o autor mostra que a tradição assimilacionista, que caracteriza a formação do Estado brasileiro desde seus primórdios, não desapareceu. Ao analisar a relação de vários séculos entre os Canela e os não-indígenas em torno da educação formal, Macena constatou que, apesar das mudanças na Constituição de 1988:

Os antigos paradigmas que nortearam a elaboração das políticas de educação para os povos indígenas ao longo de todos esses anos, não podem ser, simplesmente, apagados, algumas antigas práticas e ideologias ainda persistem, explícita ou implicitamente.” (2007:15)

Assim, embora exista uma vontade difusa para que os indígenas participem dos projetos e serviços oferecidos pelos órgãos públicos, organizações nãogovernamentais ou outras instituições, inclusive na educação formal, o que realmente acontece entre os Canela é que tais projetos continuam sendo pensados e aplicados, em última instância, sem a participação dos índios - ou com uma participação apenas parcial. Como mostrarei nos capítulos 3 e 4, essa constatação não se limita aos Canela. Também pode ser feita para os Tapayúna, o que deve nos levar a refletir sobre a capacidade dos não-indígenas para realmente construir um diálogo efetivo com outras tradições de organização social, pontualmente aquelas que podem ser classificadas como nativas ou indígenas e, portanto, potencialmente tuteláveis.

Em sua dissertação de mestrado, Macena assevera, ainda, que a escola canela, na visão dos próprios professores indígenas, deve ensinar satisfatoriamente o que os indígenas querem aprender dos não-indígenas e não tentar e 'emular' ou sistematizar os conhecimentos canela. Nesse sentido, "disciplinas como arte e cultura indígena, por exemplo, segundo a professora, não possuem utilidade alguma em suas escolas." (ibid idem :81). 
Outra análise interessante, também focada na educação formal entre os povos indígenas, é a de Karenina Vieira Andrade sobre os Ye'kuana que vivem na Terra Indígena Yanomami em Roraima (Andrade, 2007). Seguindo o mesmo mote da análise de Macena entre os Canela, a autora argumenta que:

Embora condenassem a conversão à religião dos brancos, logo os líderes [ye'kuana] ficaram interessados em aprender o sistema de escrita. A princípio, mais do que aprender a escrever em ye'kuana, era o desejo de aprender a escrever a língua dos brancos que interessava. (idem :175)

Portanto, segunda a autora, a curiosidade e interesse maior dos Ye'kuana também era aprender o código de comunicação não-verbal dos não-indígenas e não transformar a comunicação oral indígena nos moldes daquele código não-verbal. Contudo, tal tentativa de adquirir certas técnicas não-indígenas não se faz sem dificuldades. A autora mostra que esse processo está eivado de riscos para os Ye'kuyana, sendo o maior deles, segundo as lideranças, o alto índice de suicídios entre os jovens desse povo e o desrespeito que os últimos apresentam, por vezes, em relação às próprias lideranças e indígenas mais velhos, fato incumbido ao contato com os não-indígenas, mais pontualmente à implantação da educação formal (ibid idem $\mathrm{e}$ também em Andrade, 2009).

Gustavo Hamilton de Souza Menezes apresentou uma opinião semelhante em seu estudo da educação escolar entre os Yanonami. ${ }^{24}$ Referindo-se, principalmente, aos indígenas mais velhos, o autor afirma que eles "consideram que os conhecimentos tradicionais Yanonami devem ser garantidos pela comunidade numa esfera própria, externa à escola. E que a escola deve ser justamente um espaço para se conquistar o conhecimento do mundo exterior" (Menezes, 2013 :56). Na verdade, para esse grupo indígena, a dita educação "diferenciada" pode ser mesmo sinônimo de uma educação ruim, já que:

\footnotetext{
${ }^{24} \mathrm{O}$ termo não está grafado incorretamente: os indígenas estudados por Menezes se autodesignam "Yanonami", e não "Yanomami". De todo modo, os Yanonami podem ser vistos como um subgrupo Yanomami, segundo o próprio autor.
} 
entre alguns Yanonami há um ceticismo em relação aos projetos educacionais que propõem uma "educação diferenciada". Eles temem que sob esse rótulo, lhes seja oferecida uma escolarização de qualidade inferior àquela regularmente oferecida nas escolas não-indígenas." (idem :49).

Para tornar as coisas ainda mais complexas, os Yanonami preferem a educação missionária, que até hoje lhes é oferecida, à escola laica do Estado:

Apesar de reconhecerem a importância da escola, os Yanonami admitem que a ela falta maior adequação às características próprias de sua cultura, como preconizado pela lei. Sabem que os salesianos e a escola por eles dirigida não são indiferentes, mas contrários a certos aspectos da tradição Yanonami. Contudo, preferem manter-se ligados aos missionários e à maneira pouco diferenciada e altamente religiosa com que eles conduzem a escola, do que reivindicar a saída dos mesmos e a implantação, através da SEDUC [Secretaria Estadual de Educação de Roraima], de uma escola realmente específica e diferenciada, uma vez que eles têm consciência de que tal tentativa teria grande possibilidade de falhar. (ibid idem :53)

A escola como uma instituição privilegiada para entender o mundo dos nãoindígenas e aprender, por exemplo, a língua portuguesa também aparece na tese de doutorado de Onilda Sanches Nincão (2008). Ao discutir a educação formal entre os Terena, a autora argumenta que a escola se transformaria "em um instrumento de defesa, na medida em que através dela podia-se compreender o mundo e os códigos não-índios. Aprender português era uma necessidade vital para o povo e a escola era o locus privilegiado para isso." (idem :37)

Ao analisar a educação formal na região do Alto Rio Negro, Cristiane Lasmar (2009) chega a uma conclusão semelhante, sem deixar de lado a complexidade desse processo. Segundo a autora: 
A absorção do conhecimento dos brancos envolveria, assim, um devir branco e isso coloca para os índios um dilema, se, por um lado, a apropriação do conhecimento dos brancos representa uma forma de agência sobre a situação presente e futura, por outro, ele envolve um risco para a própria identidade indígena, que têm na noção de comunidade um importante sustentáculo, como já vimos. Formulando de maneira sintética, o problema que está posto atualmente para os índios Uaupés é o de como se apropriar do conhecimento dos brancos sem precisar viver com branco, isto é, sem precisar viver como se vive na cidade." (idem :23)

Para vários povos indígenas dessa região, as cidades foram, durante muito tempo, a única opção de educação formal disponível. ${ }^{25}$ Lasmar mostra que no Alto Rio Negro, a educação formal foi introduzida entre a população indígena da região por uma missão católica salesiana. Os homens mais velhos ainda se recordam quando os padres apareceram recrutando crianças para o internato cristão no qual passavam longas temporadas fora de suas comunidades de origem, vivendo um sistema de rígida disciplina, com obrigatoriedade de estudo proselitista e trabalhos manuais (ibid idem :06).

O movimento indígena organizado também levou ao surgimento recente de uma nova intelectualidade indígena que passou a frequentar as universidades de modo geral e os programas de pós-graduação em antropologia em particular. Nesse contexto, surgiram análises sobre a educação pública escolar diretamente escritas por pensadores indígenas, comprometidos com a vida de seus povos. Faço referência, aqui à dissertação de mestrado de Tonico Benites (2009) e à tese de doutorado de Gersem Luciano (2012), dois antropólogos indígenas que analisaram diretamente o processo de escolarização formal de seus povos - respectivamente, os Ava Kaiowá e os Baniwa. Começarei pela tese de doutorado de Gersem Luciano, defendida no Programa de Pós-Graduação em Antropologia Social da Universidade de Brasília.

É interessante notar que o tema da educação escolar indígena tem ocupado um lugar central na reflexão antropológica de Luciano. No início do seu doutorado, o

\footnotetext{
${ }^{25}$ Essa é uma questão central entre os Tapayúna e será abordada mais pontualmente no capítulo 3.
} 
autor publicou um artigo no qual fez um bom levantamento da relação (nem sempre complementar) entre o movimento indígena e indigenista nas últimas décadas da história brasileira, bem como uma análise do acesso indígena ao ensino superior no Brasil (Luciano 2009). Sua tese de doutorado é uma referência nos estudos sobre educação formal entre povos indígenas. Ela tem um caráter quase autobiográfico e, embora focando o contexto específico da região do Alto Rio Negro, tece, a partir dele, considerações mais gerais sobre educação escolar indígena que dialogam com a análise de Grupioni e encontram muitas semelhanças com os casos etnográficos mencionadas anteriormente. Assim, Luciano afirma que:

a escola foi escolhida [pelos grupos indígenas da região do AltoRio Negro] como um dos principais meios para essa apropriação de conhecimentos dos brancos e dos seus modos de vida. A escola indígena, portanto, não é vista como instrumento preferencial de fortalecimento ou resgate de culturas e identidades tradicionais, como pressupõe a ideia mais comum de escola indígena diferenciada, mas como mecanismo de aproximação e interação com o mundo extra-aldeia global. (idem $: 05)$

Contrariamente a Grupioni, Luciano não parece estar muito interessado em defender uma educação escolar indígena ancorada na defesa das tradições socioculturais nativas, ou seja, uma escola que estimularia o aprendizado dos conhecimentos próprios dos povos indígenas. $\mathrm{O}$ autor se mostra até bastante crítico a esse tipo de escola:

a educação indígena intercultural ou escola indígena diferenciada ou específica, mesmo como modelos alternativos de educação e de escola, não foram e não serão suficientes para responder às demandas apresentadas pelos povos indígenas à escola. (ibid idem :72). 
É preciso notar, contudo, que Grupioni trata de vários contextos sociológicos, por vezes bastante distintos daquele analisado por Luciano. Enquanto este último aproveita sua própria trajetória de professor indígena e liderança política do Alto Rio Negro para produzir um trabalho largamente inspirado em sua experiência de vida, o primeiro trata de questões gerais, referentes ao Brasil como um todo, e lida com uma grande diversidade de situações etnográficas, inclusive com exemplos de indígenas do nordeste do país, entre os quais a chamada educação diferenciada parece apresentar contornos distintos. Assim, fazendo referência a uma dessas situações dos índios do Nordeste, Grupioni afirma:

Premidos pela cobrança de que perderam sua língua e, portanto sua cultura, os Potiguara da Paraíba instrumentalizam a escola como via de construção de emblemas de uma cultura a ser "resgatada", em que propõem uma "volta às origens" por meio, dentre outros recursos, da tentativa de se tornarem falantes de uma língua morta." (Grupioni, op. cit :209)

Como mostram os exemplos dos Baniwa e dos Potiguara, a educação diferenciada pode, portanto, assumir contornos muito diversos, dependendo, entre outras coisas, das especificidades dos grupos indígenas e das características dos projetos educacionais. Esse parece ser justamente o 'espírito' do tratamento dispensado aos indígenas na Constituição de 1988: a educação e a saúde devem ser, de fato, diferentes para cada situação concreta apresentada, para cada grupo indígena e seu contexto sociológico específico.

Outra ótima análise do processo de educação formal de povos nativoamericanos no Brasil pode ser encontrada na dissertação de mestrado de Tônico Benites (2009). Como Gersem Luciano entre os Baniwa, Benites é uma liderança política dos Ava Kaiowá do Mato Grosso do Sul - por vezes referidos como Guarani Kaiowá. Ainda como Luciano, Benites foi professor indígena na sua região e relata a trajetória e experiência que teve nesse contexto específico. $\mathrm{O}$ relato autobiográfico parece, assim, adquirir uma importância muito peculiar entre os intelectuais 
indígenas. ${ }^{26}$ Em sua trajetória, Benites também foi informante de antropólogos e tradutor das lideranças mais antigas de seu povo (idem :11). Assim, é bastante interessante a visão que ele apresenta dos condicionantes da sua própria pesquisa:

Em relação à minha pesquisa sobre a escola na visão do Kaiowá, tenho perfeita consciência de ela está sendo monitorada e analisada tanto pelos indígenas quanto pelos não-indígenas. Percebi que os meus discursos e minha crítica em relação às práticas escolares geram comentários diversos, às vezes dividem também opiniões entre os pesquisadores em educação indígena e professores indígenas. $\mathrm{Na}$ verdade, estou sendo pesquisado também pelos próprios indígenas e não-indígenas. (ibid ibem :13)

Essa passagem de Tonico Benites mostra bem as pressões que podem sofrer os pesquisadores indígenas, principalmente os antropólogos, quando pretendem pesquisar e produzir material acadêmico sobre sua própria sociedade. Ao mesmo tempo que lhes é demandado construir um texto com o rigor exigido pela academia, eles também precisam responder às exigências políticas que deram condições para que eles chegassem ao mestrado ou doutorado. Sua posição política, como índios universitários, se deu pela organização e pressão do movimento indígena e indigenista - e não apenas pelo esforço individual de cada acadêmico indígena, apesar deste último fator também ser importante. Assim, eles devem atender não só à normatização e à excelência acadêmica instituída nos cursos de pós-graduação, mas também às solicitações de seus próprios povos que demandam que o trabalho acadêmico tenha algum retorno positivo para a comunidade de origem.

Todo o estudo de Benites está baseado na premissa de que, entre os Avá Kaiowá, não há uma tradição de organização política com foco na centralização de poder, seja na figura de um chefe local ou de um conselho mais numeroso. ${ }^{27}$ Mais que

\footnotetext{
${ }^{26}$ Dominique Gallois et alii (2016) notaram o papel central que as narrativas de vida tem nas "autoetnografias": "chamamos atenção para um aspecto que pode indicar outra peculiaridade do fazer antropológico por indígenas: a constante explicitação por eles da própria trajetória de vida como (parte da) metodologia utilizada na pesquisa." (:16). Nesse sentido, os trabalhos de Luciano e Benites são exemplares.

${ }^{27}$ Apesar de não ser diretamente citado por Tonico Benites, vale fazer referência aqui ao seminal estudo de Pierre Clastres sobre as sociedades contra o Estado (Clastres, 1978). Este autor demonstra que boa parte dos grupos humanos da América que não estão baseados numa centralização do exercício
} 
isso, o antropólogo assevera que cada família extensa pode escolher se organizar da maneira que melhor lhe aprouver.

Assim, há famílias extensas que possuem uma estreita relação, por exemplo, com a missão evangélica local, enquanto outras escolheram explicitamente manter o primado de agência do xamã, com seus ritos e cosmologias não-cristãos. Contudo, ainda assim, há uma espécie de 'distanciamento relativo' entre as famílias cristãs e os próprios missionários, que faz com que as primeiras, em diversas situações políticas, estejam mais próximas de outras famílias extensas não-cristãs do que dos nãoindígenas cristãos.

Esse distanciamento relativo parece estar calcado, entre outros fatores, no compartilhamento de uma mesma língua, nas relações de casamento exogâmicas entre as famílias e, além disso, na própria liberdade de escolha garantida a cada família extensa. Essa liberdade comporta, assim, um 'fundo sociológico' comum entre todos aqueles que se autodenominam Ava Kaiowá. Tonico Benites identifica a expressão linguística específica que dá nome a esse 'fundo': ava kuera reko reta, cuja tradução, feita pelo próprio autor/liderança Ava Kaiowá, é "o modo de ser múltiplo" dos Ava Kaiowá (ibid idem, :102).

Nesse contexto, a escola foi, ao mesmo tempo, uma força de mudança e, também 'indigenizada' pela lógica Ava Kaiowá. Segundo Benites, o SPI e, mais tarde, a Funai criaram, para cada agrupamento desse povo, um "capitão indígena", que teria a função de mediar a relação dos Kaiowá com os não-indígenas. Com o contato, se multiplicaram as salas de aula de ensino formal, com anuência de parte das lideranças indígenas das famílias extensas. As escolas eram ligadas ou à já citada missão evangélica ou ao órgão indigenista federal. Mais tarde, essas últimas também foram estadualizadas no mesmo processo que descrevemos acima (cf. Grupioni op. cit.). De todo modo, até hoje, a missão evangélica possui influência na educação dos Ava Kaiowá (ibid idem :90).

Tonico Benites mapeia a rede que sustenta esse sistema político: as famílias extensas mais prestigiadas conseguem eleger o "capitão" de suas localidades; este último, ainda com o suporte das famílias, apoia a eleição de prefeitos e vereadores

da violência física se organizam dessa maneira não por uma falta ou desconhecimento de um sistema pretensamente mais eficaz ou evoluído, mas por terem cunhado e mantido, durante sua história, uma organização social que não passa pela referida centralização. Isso acontece ainda que, de alguma forma, a potencialidade dessa centralização política seja uma ameaça constantemente combatida pelas "sociedades arcaicas", que é como Clastres denomina os nativo-americanos. 
locais não-indígenas; por fim, esses políticos garantem que aqueles indicados pelo "capitão" local assumam os cargos públicos assalariados nas terras indígenas de sua responsabilidade, como os de professor-indígena, por um lado, ou Agentes Indígenas de Saúde (AIS), por outro. Esse sistema 'injeta' um quê de violência direta, centralização de poder e concorrência desigual entre as famílias. Isso, segundo Benites, não é típico dos Ava Kaiowá, mas coloca em xeque o próprio "modo de ser múltiplo" dessa população. (ibid ibem capítulos III e Considerações Finais).

Tonico Benites também corrobora a visão de educação indígena de Gersem Luciano. Assim, segundo ele:

A maioria das famílias Ava Kaiowá consideram que os conhecimentos centrais para a própria vida Kaiowá não podem ser ensinados pelos não-indígenas, que vivem em uma outra cultura (teko), que é o karai reko. Por essa razão, é relevante considerar que até hoje a família extensa não depende da escola e do papel escrito (kuatia ñe'e) para educar suas crianças a ser Ava Kaiowá. Para ser Ava Kaiowá as crianças aprendem vivendo com os membros parentes, educadores exclusivos da família. [...] Cada família Ava Kaiowá é uma instituição social que possui vários educadores eficazes ou professores exclusivos, responsáveis por ensinar com eficácia a sua tradição às crianças, socializando entre os integrantes neófitos o modo de ser e viver. Portanto seria totalmente equivocado argumentar que uma instituição burocrática externa a essas famílias, como o sistema de escola homogeneizante, oferecido pelo Estado, possa substituir esse papel de educador de cada família. (ibid idem :95, ênfases do original)

Cabe fazer uma última consideração sobre a pesquisa de Tonico Benites. Os Ava Kaiowá tiveram seus primeiros contatos com a educação formal com uma missão presbiteriana. Esse processo ocorreu após a laicização oficial do Estado brasileiro, iniciado no final do século XIX, o que mostra que o surgimento de um Estado laico não pôs fim ao proselitismo missionário no contato com os índios. Na verdade, abriu- 
se a possibilidade, para outros grupos cristãos, além dos católicos, organizarem e efetivarem projetos proselitistas entre povos nativos em todo o território nacional. Assim, Benites assevera que "[...] os funcionários do SPI estabeleceram parcerias com as instituições religiosas no que toca à educação escolar, permitindo que esta se realizasse conjuntamente com atividades de evangelização. (ibid idem :31)". Ou seja, no anseio de civilizar os índios, a República brasileira dita laica usou todas as armas disponíveis, nunca abandonando por completo o apoio dos missionários. $\mathrm{O}$ caso dos Ava Kaiowá não é, obviamente, único. A mistura espúria entre projetos proselitistas e projetos civilizatórios laicos parece ter perdido força depois da maior organização política do movimento indígena e indigenista e, consequentemente, depois das possibilidades legais abertas pela Constituição de 1988. No entanto, missionários continuam atuando nas terras indígenas, principalmente na área de educação. Podemos, para citar um único exemplo, citar o famoso Summer Instituto of Linguistics, uma instituição proselitista evangélica disfarçada em um instituto de pesquisa que é citada nos mais diferentes estudos sobre a educação formal entre os indígenas no Brasil. Para nos limitarmos aos trabalhos citados nas páginas anteriores, vimos que a educação formal básica de Gersem Luciano se deu dentro de uma missão salesiana e que os Yanonami, até hoje, usam a educação proselitista que lhes é oferecida.

Como mostra a análise geral de Grupioni e os exemplos etnográficos de Macena, Andrade, Nincão, Lasmar, Luciano e Benites, os estudos sobre educação formal indígena no Brasil tendem a se pautar, atualmente, na análise da adaptação do ensino escolar às condições socioculturais de determinado povo. Tendo o contexto de minha própria pesquisa em mente, a Escola Estadual Goronã não me pareceu, inicialmente, um espaço para o "resgate" cultural ou uma "volta às origens". Os Tapayúna querem ensinar, ainda que em língua nativa, o letramento e outras técnicas específicas da sociedade não-indígena, como a matemática, por exemplo, um ótimo conhecimento para as transações comerciais com outros indígenas e não-indígenas. Saber ler e falar razoavelmente o Português também ajuda os Tapayúna a se deslocarem de maneira mais cômoda pelas cidades da região, identificando, por exemplo, qual ônibus de uma rodoviária segue para tal ou qual lugar ou, ainda, qual o número do assento numerado de sua poltrona. Podem, do mesmo modo, ter maior independência em situações como a compra ou recebimento gratuito de um remédio 
receitado ou, por vezes, na gerência de uma conta bancária, no caso das pessoas com aposentadoria rural ou outro tipo de benefício em dinheiro.

Dessa forma, para os Tapayúna, construir uma escola propriamente diferenciada não é criar uma escola para ensinar, entre outras coisas, a própria cultura. Não é, portanto, uma maneira resgatar traços socioculturais. Com base nos dados etnográficos que pude recolher para a presente tese, corroboro a posição de Luciano quando afirma: "[...] prefiro sugerir que a escola indígena se dedique preferencialmente a possibilitar o acesso adequado e eficiente aos conhecimentos do mundo branco de interesses dos povos indígenas" (Luciano, op. cit. :104).

Isso não significa dizer, é claro, que a escola dos Yanomami, Baniwa ou dos Tapayúna deva ser uma cópia da escola tradicional não-indígena. Em conformidade com a legislação vigente, cada escola indígena deve levar em conta, na sua composição e no ensino, o contexto específico e as peculiaridades culturais do povo indígena ao qual ela se destina e que deve gerenciá-la. No caso da Escola Goronã em Kawerêtxikô, ela foi uma legítima reivindicação dos Tapayúna frente à eufêmica 'sociedade envolvente'. Como mostrarei no capítulo 3, ela é quase que completamente gerida pelos Tapayúna - ao menos no que tange à sua administração direta, mas esse não é o caso de todas as escolas indígenas do Brasil ${ }^{28}$. Isso não quer dizer, como veremos, que não existam imposições, principalmente por parte do corpo administrativo da Secretaria Estadual de Educação do Mato Grosso, de diversas exigências, algumas delas, inclusive, de cunho explicitamente ilegal quando pensamos na garantia constitucional de uma escola diferenciada.

Finalizarei essa discussão sobre educação escolar indígena explorando algumas dimensões da tensão entre a oralidade e o escrita. Como notou Lévi-Strauss (1996), a educação formal entre povos indígenas nos remete à clássica tensão entre sociedades orais e sociedades letradas. Na Amazônia, vários outros autores tem refletido sobre esse tema nos últimos anos. É o caso, por exemplo, de Bruna

\footnotetext{
${ }^{28}$ A escola dos Yanonami, como vimos, é somente um exemplo. Podemos ainda citar a escola instalada na aldeia de Piaraçu, localidade dos Mebengôkrê (Kayapó) que fica há alguns kilômetros de Kawerêtxikô. Pelo que pude notar, depois que essa escola deixou de ser responsabilidade legal da Funai e passou para a administração do estado do Mato Grosso, ela começou a oferecer diversos cursos e disciplinas com professores não-indígenas, que aumentaram sua ingerência na escola, justamente sob o argumento de que dariam as disciplinas não-indígenas que interessavam aos Mebengôkrê com maior qualidade que a Funai. Do mesmo modo, quando a Secretaria Estadual de Educação (SEDUC, MT) passou a ser a responsável legal pela educação formal em Piaraçu, também houve um retrocesso na linha pedagógica e no conteúdo, embora a administração direta dessa escola (diretores e coordenadores pedagógicos) esteja nas mãos dos Kayapó.
} 
Franchetto (2008 e 2011), Adriana Testa (2008), Peter Gow (2010), João Gerald (2000), Antonella Tassinari (2001b), Ingrid Weber (2006) ou Eliane Camargo e Célia Nhii (2001).

Em seu trabalho com os Piro da Amazônia peruana, Peter Gow criticou a posição ambígua de alguns antropólogos que consideram o letramento um mal a ser evitado para povos de contato recente, enquanto que, para outros com maior tempo de contato com os não-indígenas, ele seria de suma importância:

Es como si los etnógrafos de las culturas amazónicas estuvieran de acuerdo com Lévi-Strauss em que la escritura constituye un gran mal del cual se han salvado estos pueblos, al tiempo que afirman que la alfabetización constituye una gran bendición para ellos a partir del momento em que entran em contato permanente com la sociedad nacional (op. cit. :106)

Gow aproxima, de forma interessante, a alfabetização e a arte dos desenhos dos Piro mostrando que o mesmo termo (yona) é utilizado pelos indígenas tanto para se referir aos desenhos gráficos como às letras. Entre esse povo indígena, Sangama, o primeiro homem a dominar o letramento, o descreve como um diálogo com uma sensual mulher de lábios vermelhos que, a partir do papel e seus grafismos, falava com o leitor que sabia como interpretá-los (idem :113). Para os Piro, a escrita e a leitura podem ser um conhecimento do tipo xamânico, completamente oculto para as pessoas comuns e revelado para poucos. Assim, em grande medida, essa duas técnicas não podem ser 'ensinadas formalmente', mas são características que nascem com o xamã (ibid idem :115). Como entre os Tapayúna, o papel do xamã é eminentemente masculino, existindo pessoas que "no requeren de entrenamiento para devenir shamanes. De esta manera, Zumaeta sugiere que Sangama podía ller porque era un shamán nato y su extraordinario conocimiento de la lectura se originaba em su interior." (ibid idem :115).

Essa maneira de tratar o letramento indígena, não o qualificando de antemão como uma 'falta', mas sim como uma forma de sociabilidade que se desenvolveu de forma diferente do que na tradição não-indígena, inspirou diversos outros autores. 
Refletindo sobre a escrita entre os Kaxinawá, a antropóloga Ingrid Weber, por exemplo, argumenta que:

[...] é revelador o fato de o termo originalmente usado para os desenhos gráficos piro - yona - ser o mesmo utilizado para se referir às letras e, portanto, à escrita. Entre os Kaxinawá acontece o mesmo, e o termo para se referir tanto aos desenhos quanto à escrita é kene. Para entender essa relação, ao invés de tentar buscar no sistema gráfico piro uma suposta dimensão semântica, o autor [Peter Gow, estudando os Piro] percebe que a apreensão piro da escrita está, antes, relacionada à percepção estética. $\mathrm{Na}$ arte gráfica piro, bem como na arte kaxinawá, um aspecto fundamental é a habilidade de adaptar o desenho à superfície sobre a qual ele está inscrito: "As mulheres Piro com quem eu discuti esses desenhos tinham pouco a dizer sobre tipos particulares de desenho, mas se mostravam muito mais comunicativas quando o assunto era a maneira como um desenho específico adaptava-se, em sua execução, à superfície de suporte" (Ibid. :8, tradução nossa). Com essa referência em mente, tornase mais fácil compreender porque Sangama [primeiro leitor piro] tanto enfatizava o papel, propriamente, ao invés da escrita (enquanto ferramenta e significado). Para os Kaxinawá, no início, a escrita e o papel parecer ter sido apreendidos de forma semelhante. (Weber, op. cit, :85)

Essa analogia entre escrita e desenhos também é visível entre os Tapayúna. Antes de tomar conhecimento da etnografia de Ingrid Weber, eu já havia lido o texto de Gow e percebi que os Tapayúna, como os Piro e os Kaxinawá, identificam uma pessoa "alfabetizada" não apenas pelo fato dela dominar relativamente bem a técnica da escrita e leitura, mas também pela beleza de sua letra. Assim, uma pessoa bem alfabetizada possui uma letra tida como esteticamente bonita e adaptada ao quadro negro, como demonstrarei no capítulo 3. 
Embora não resolvam a tensão entre oralidade e escrita, esses exemplos mostram como a escrita é, em algum grau, 'indigenizada'. Cabe notar que esse processo de 'indigenização' está presente não só no contexto escolar: ele parece permear toda a relação dos Tapayúna e outros povos com aquilo que vem de fora, principalmente dos não-indígenas, mas não exclusivamente. Para citar um outro exemplo, a relação dos Kaykwakhratxi com os produtos industrializados é pautada pelo que Catherine Howard corretamente denominou, ao se referir aos Waiwai, de "domesticação das mercadorias" (Howard, 2002). Mais que isso, o uso do dinheiro recebido com salários, aposentadorias rurais e outros benefícios pode ser comparável ao uso que os Xikrin do Pará, estudados por César Gordon, fazem desses benefícios (Gordon 2006). Tratarei desse tema com mais detalhes no capítulo 3.

De forma semelhante, os Tapayúna também incorporaram tradições externas de outros indígenas. Podemos usar o exemplo da rede de dormir ou descansar. Os Tapayúna não conheciam e não dormiam em rede antes do contato mais sistemático com os Kinsedje e os Mebengôkrê (Batista de Lima, op. cit. :143). Usavam esteiras que até hoje continuam sendo fabricadas pelas mulheres em diversos tamanhos e com diferentes propósitos, inclusive para se forrar os colchões adquiridos nas relações com os não-indígenas. Com o contato com esses povos indígenas vizinhos, eles passaram a incorporar a rede que não fazia parte de sua tradição e é usada hoje com a mesma desenvoltura que os Mebengôkrê.

Para concluir essa discussão sobre educação formal indígena, gostaria de ressaltar que a educação formal já foi e ainda pode ser parte de um projeto consciente de 'fagocitação' das populações indígenas visando acabar com suas especificidades culturais. No entanto, esse processo não se dá, hoje, de maneira simples ou direta. O letramento paulatino de parte considerável de um povo indígena que antes ignorava o a escrita também não significa que esse povo está se aculturando ou se tornando necessariamente menos indígena, embora a 'indigenização' da escrita também comporte uma parcial 'branquização ${ }^{29}$ dos indígenas. Tratarei dessas questões mais pontualmente no desenvolver dos próximos capítulos.

\footnotetext{
${ }^{29}$ Como visto na Introdução, na escrita da presente tese, decidi evitar o uso do termo "brancos" e correlatos. Tentei substituí-los, sempre que possível, pela categoria de não-indígena ou, no máximo, ocidental. Contudo, em alguma situações, como essa acima, encontrei sérias dificuldades em deixar o termo de lado. De todo modo, esclareço que pensei em usar a categoria de não-indígena em detrimento de "branco(s)" pois o primeiro termo me pareceu ser menos homogeneizante de que o último. Porém, tenho consciência de que a simples substituição de um significante pelo outro não altera em muito a
} 


\subsection{Os estudos sobre saúde alopática entre os indígenas}

As análises sobre saúde alopática tendo as populações indígenas como referência também são numerosas, contudo, em volume bem menor que os de educação. Por essa razão, darei a eles um tratamento menos extenso.

Não há qualquer sistematização sobre os estudos de saúde indígena no Brasil que supere a bibliografia crítica de Dominique Buchillet (2006). Baseada em uma experiência de 15 anos com o tema, a autora faz um pormenorizado levantamento dessa temática. Para elaborar sua bibliografia, Buchillet pesquisou em bibliotecas físicas de Brasília, Rio de Janeiro e São Paulo e, além disso, em diversos bancos de dados digitais, nacionais e internacionais (idem :12). As mais de três mil referências compiladas, organizadas em diversos índices, cobrem uma vasta área científica: desde estudos sobre xamanismo e terapêutica propriamente indígena até trabalhos sobre genética humana e antropologia física ${ }^{30}$.

Carla Costa Teixeira e Cristina Dias Silva (Teixeira \& Silva, 2002) também apresentaram uma análise geral muito interessante sobre uma extensa bibliografia, baseada num amplo levantamento de teses e dissertações através do portal de Internet de uma grande agência pública financiadora de pesquisas no Brasil. As autoras chegam à conclusão de que a subárea da antropologia da saúde não comporta um novo tipo de antropologia social e, assim, tem as mesmas bases e pressupostos teóricos e metodológicos que da antropologia social como um todo.

empreitada de complexificação da ideia enviesada de uma sociedade envolvente completamente homogênea frente à diversidade de etnias indígenas.

${ }^{30}$ Há dois estudos, nessa bibliografia crítica, citando os Tapayúna: um primeiro, de referência "Cunha, E.S., 1969. Os Beiço-de-Pau. Deformações dentárias tegumentares e afecções alvéolo-dentárias. In: E.S. Cunha (org.), Anais da Sétima Jornada Fluminense de Odontologia "Prof. Coelho e Souza" [Niteroi, 1969], pp. 20-25. Niteroi: Faculdade de Odontologia, Universidade Federal Fluminense."; e um segundo "Pinto N.R. da S. \& R.G. Baruzzi, 1991. Male pubertal seclusion and risk of death in Indians from Alto Xingu, Central Brazil. In C.E.A. Coimbra Jr. (ed.), Symposium on Recent Trends of Bioanthropological Research among Lowland South American Indian Populations [59th Annual Meeting of the American Association of Physical Anthropologists, Miami, 1990], Human Biology, 63(6):821-834]." Pelo resumo de ambos, também publicado na obra de Buchillet, nota-se que se trata de trabalhos voltados a estudar os corpos dos Tapayúna, e não exatamente a sociabilidade entre os últimos. Tratarei, no desenvolver do presente capítulo, da questão do tratamento terapêutico dos corpos. 
Numa coletânea recente, organizada por Carla Costa Teixeira e Luiza Garnelo (Teixeira e Garnelo, 2014), encontramos estudos sobre as origens do subsistema de atenção à saúde indígena no Brasil (Parte 1) e vários casos etnográficos que mostram, na prática, como determinados povos indígenas se relacionam com a terapêutica oferecida pelo Estado brasileiro (Parte 2). No capítulo 5 de sua tese de doutorado, orientada por Carla Costa Teixeira, Cristina Dias Silva faz também um histórico da enfermagem no Brasil e mostra seu papel central no tratamento de saúde alopática oferecido pelo Estado brasileiro às populações indígenas (Silva, 2010 :242-263).

Para iniciar a discussão sobre a saúde alopática indígena, considero importante fazer algumas considerações prévias sobre a terapêutica ocidental para a cura dos corpos. Assim, apresentarei uma breve discussão sobre o chamado Ato Médico e suas repercussões no tratamento geral de indígenas e não-indígenas. O Ato Médico não é um texto acadêmico. Trata-se de uma lei promulgada em 2013 por Dilma Rousseff, então presidente da República brasileira. ${ }^{31}$ Penso que lembrar o processo de discussão que levou à implementação dessa lei ajudará a contextualizar melhor a discussão sobre saúde alopática indígena.

A regulamentação do trabalho dos médicos pela atual República brasileira levou mais de uma década: dois projetos de lei tramitaram por doze anos no Parlamento até a promulgação da referida lei. O Ato Médico aprovado por Dilma Rousseff não foi exatamente a mesma versão que tramitava no Senado. ${ }^{32}$ Toda a discussão política da época esteve voltada para os artigos vetados pela presidente. A supressão e edição de artigos mudou, de maneira importante, o sentido da letra da lei aprovada nas duas casas do legislativo. Há de se notar que o Conselho Federal de Medicina (CFM) acompanhou a tramitação e apoiou a promulgação da lei sem nenhum tipo de veto presidencial, se contrapondo à presidente.

A polêmica gerada pelos vetos/edição de alguns artigos tem a ver diretamente com a discussão da terapêutica dos corpos. Em última instância, tratava-se de se definir os profissionais que podiam ou não fazer diagnósticos de corpos tidos como

31 http://www.planalto.gov.br/ccivil_03/_Ato2011-2014/2013/Lei/L12842.htm, com acesso em $24 / 02 / 16$

${ }^{32}$ Toda a discussão que aqui apresento tem como fundo diversos artigos jornalísticos da página oficial da Empresa Brasil de Comunicação (EBC) ou Agência Brasil: http://www.ebc.com.br/, com acessos durante a última semana de abril de 2016. Além disso, a enfermeira da Rede Sarah de Hospitais em Brasília, Karine Rodrigues de Afonseca, prestou-me importante assistência sobre o uso prático da lei. 
doentes ou com algum tipo de anomalia e, além disso, identificar aqueles que seriam autorizados a tratar tais corpos e de que maneira.

Em relação ao tratamento, estava particularmente em jogo a questão de quem o Estado formalmente autorizaria a adentrar, terapeuticamente, os corpos humanos. Mais que isso, estava em pauta o reconhecimento legal ou não da possibilidade desses corpos sofrerem intervenções estéticas que se assemelham às intervenções terapêuticas, mas não sempre praticadas por médicos e nem sempre possuindo o fim último de cura ou tratamento de alguma anomalia.

Nesse contexto, o projeto de lei inicialmente proposto para a discussão nas duas casas do Congresso Nacional dava exclusividade aos médicos formados e filiados a algum Conselho Regional de Medicina (CRM) a autorização para adentrar o corpo humano. Os tatuadores e os profissionais que trabalhavam com piercings e outros adornos estéticos se colocaram veemente contra o projeto de lei nesses termos. Da maneira como foi aprovado no Senado, o Ato Médico impossibilitaria que especialistas diversos que não aqueles com graduação em medicina aplicassem injeções ou fizessem qualquer tipo de ação invasiva nos corpos humanos. Portanto, as pessoas que tivessem como ofício a execução de tatuagens ou piercings estariam, tecnicamente, na ilegalidade.

Além dos profissionais já citados, o texto também ia contra o exercício da profissão de enfermeiros e técnicos em enfermagem. Essas ocupações poderiam ser particularmente afetadas pois serviços como a realização de diagnósticos, a proposição de terapias ou ainda a simples aplicação intravenosa/muscular de medicamentos e outras substâncias, como vacinas, seriam vedados aos enfermeiros e técnicos e passariam, deste modo, a ser uma exclusividade médica. Como consequência direta dessa regulamentação estaria, por exemplo, o impedimento das ações públicas de vacinação em massa, que contam, na linha frente, principalmente com técnicos e enfermeiros.

Do mesmo modo, o trabalho nos postos-de-saúde indígenas, espalhados por todo o país, também seria colocado em xeque. Tomando como exemplo específico o posto-de-saúde da aldeia Kawerêtxikô, pude presenciar duas ações de vacinação de crianças que foram executadas exclusivamente por enfermeiras e técnicas em enfermagem - entre outros procedimentos, como deixarei mais claro no capítulo 4. O trabalho de organização cotidiana das diversas ações de saúde alopática na Terra 
Indígena Capoto Jarinã era feito pelas enfermeiras, enquanto as técnicas estavam na linha de frente dos atendimentos cotidianos. Médicos só apareciam de forma esporádica nas aldeias da região. Uma constatação semelhante foi descrita, por exemplo, por Cristina Dias da Silva (Silva 2010 :64) na pesquisa de entre os Munduruku, como veremos a seguir.

De todo modo, a Mensagem n. 286 de 02 de julho de 2013 da Subchefia de Assuntos Jurídicos da Presidência da República, justificou o veto da presidente Dilma Rousseff à parte do Artigo $4^{\circ}$ do Ato Médico da lei sob o argumento de que:

ao condicionar os procedimentos à prescrição médica, os dispositivos podem impactar significativamente o atendimento nos estabelecimentos privados de saúde e as políticas públicas do Sistema Único de Saúde, como o desenvolvimento das campanhas de vacinação. Embora esses procedimentos comumente necessitem de uma avaliação médica, há situações em que podem ser executados por outros profissionais de saúde sem a obrigatoriedade da referida prescrição médica, baseados em protocolos do Sistema Único de Saúde e dos estabelecimentos privados.

(http://www.planalto.gov.br/ccivil_03/_Ato2011-

2014/2013/Msg/VEP-287.htm, com acesso em 25/02/16)

Fica clara, então, a refrega política entre diversos profissionais para a obtenção do aval do Estado no manejo terapêutico dos corpos humanos. Há de se notar que essa disputa estava focada na delimitação da especialidade de cada um desses expertos médicos, enfermeiros, fisioterapeutas, entre outros. Essas especialidades são ensinadas, em sua maioria ${ }^{33}$, em escolas técnicas, faculdades ou universidades a partir de uma estrutura de ensino formal também avalizada pelo poder público.

Contudo, apenas uma dessas expertises se arvorou a tentar um monopólio no tratamento das doenças e outras anomalias dos corpos humanos: aqueles que são graduados nos cursos de medicina. É importante notar que o embate político se deu,

\footnotetext{
${ }^{33}$ Alguns tratamentos não-indígenas, como a acupuntura, ainda resistem à tendência de formalização total na transmissão do conhecimento para a formação de seus expertos.
} 
então, entre estes últimos, de um lado, e todo o resto das diversas especialidades nãomédicas, do outro. Esse fato, por si só, evidencia a hegemonia reivindicada pelos médicos no tratamento de saúde dentro do Estado brasileiro. De todo modo, o veto presidencial garantiu que técnicos em saúde e enfermeiros, principais funcionários da saúde alopática nas aldeias, mantivessem sua prática laboral.

Entre os textos acadêmicos que tratam da saúde alopática dos índios no Brasil destaco, inicialmente, a excelente etnografia de Cristina Dias da Silva sobre as enfermeiras e técnicas de saúde não-indígenas entre os Munduruku (Silva, 2010). Inicialmente, é possível notar que não há nenhum enfermeiro ou técnico de saúde indígena, no contexto analisado por Silva, que seja Munduruku ou de qualquer outro grupo indígena da região. Todos são, portanto, não-indígenas. Além disso, todos são, também, mulheres. Em comparação, durante todo o tempo que passei entre os Tapayúna, encontrei apenas dois técnicos de saúde homens e nenhum enfermeiro, de um grupo composto de cerca de 20 profissionais. Como no caso dos Munduruku, nenhum desses profissionais era tapayúna ou de qualquer outra etnia da região ${ }^{34}$.

Uma situação similar é descrita por Maria Inês Smiljanic (2008) sobre um subgrupo Yanomami. Essa antropóloga fez campo em duas situações diferentes: como pesquisadora visando escrever uma tese em Antropologia Social, num primeiro período no fim da década de 1990; e, além disso, também como parte de uma equipe multidisciplinar que implantava, em território dos Yanomami, um projeto de atendimento de saúde aos indígenas, já no início do século XXI.

Como dito, o Distrito Sanitário Especial Indígena (DSEI) dos Yanomami (DSY) foi o primeiro a ser implantado no Brasil (idem :06-08) e serviu de experiência para os outros Distritos. Hoje são ao todo 34 DSEIs espalhados por todo o território nacional. Essa autora também confirma que os médicos, dentistas e enfermeiros formados fazem apenas visitas “ocasionais" (ibid idem :09) à região. Como no caso já citado de Tônico Benites, Smiljanic diz que os cargos de Agente Indígena de Saúde (AIS) entraram como dádivas em um "sistema de trocas com a sociedade nacional que incluía remédios, serviços de saúde e salários" (ibid idem :14).

Assim, pelo que pude ter contato até agora, tanto no meu trabalho de campo quanto na análise bibliográfica, falar-se-á muito pouco de médicos ou dentistas no

\footnotetext{
${ }^{34}$ Tive contato, na cidade de Colider, MT, com uma enfermeira indígena. Contudo, ela não trabalhava na região da aldeia Kawerêtxikô e estava lotada nas proximidades da aldeia de sua etnia.
} 
cotidiano da saúde indígena nas aldeias. Os principais atores são as enfermeiras e as técnicas em saúde, profissionais que, como vimos, conseguiram manter uma independência relativa de agência em relação aos médicos. Por tratar justamente da ação desses profissionais, a etnografia de Cristina Dias ocupa um lugar central na minha tese.

Como mostrarei no capítulo 4, na aldeia Kawerêtxikô o dia-a-dia do atendimento de saúde alopático é feito por e para as mulheres, indígenas e nãoindígenas. Uma interessante explicação dessa característica pode ser encontrada na constante tensão entre cuidar e administrar que Cristina Dias da Silva (op. cit.) mostra ser típica das enfermeiras e técnicas em enfermagem que estão lidando com a saúde alopática indígena. Segundo essa autora:

O ponto-chave pelo qual me inseri nessa complexidade [a saúde oferecida pelo Estado aos Munduruku] foi a construção pormenorizada daquilo que constitui a própria razão de ser da profissional da enfermagem, seja enfermeira ou técnica de enfermagem: a relação entre cuidar e administrar. É partir dessas duas categorias nativas, tão expressivas no campo da enfermagem e sempre motivo de grandes embates e conflitos cotidianos entre os próprios profissionais da área, que pretendo discutir os dados etnográficos e lançar luz sobre algumas controvérsias que constituem o atual campo da saúde indígena (idem :16).

Contudo, é importe esclarecer que o recorte do estudo de Cristina Dias da Silva é diferente do meu nesta tese. A referida autora está mais interessada nas relações entre as profissionais não-indígenas, principalmente entre técnicas e enfermeiras, do que a relação entre essas profissionais e os Munduruku - apesar dela não ignorar essa última relação. Na minha análise do caso dos Tapayúna, penso ser mais vantajoso mapear as relações desses últimos com a saúde alopática e compará-las com as relações que eles firmam em outro campo, o da educação formal, com os nãoindígenas. 
Fora essa diferença, a descrição de Silva se aproxima em muito da realidade que encontrei em Kawerêtxikô. Há, sem dúvidas, dois estilos bem diferentes de atender e se relacionar, de maneira geral, com os indígenas: um mais focado na noção de cuidado, de atendimento pronto e constante às doenças e outros problemas dos pacientes que vão ao posto-de-saúde, ainda que isso obrigue a profissional a fazer diversos improvisos; outro com uma ênfase maior no 'profissionalismo', na falta de termo melhor, no preenchimento das guias de atendimento e fomento de dados estatísticos, no tratamento técnica e cientificamente referenciado e no controle cuidadoso do censo da população em geral e, particularmente, dos doentes (ibid idem capítulos 2 e 3). É claro que a autora está falando de predominâncias, estilos ou tipos ideais e não de categorias estanques que não se relacionam. De todo modo, as nãoindígenas que trabalham com a saúde podem ser classificadas em algum lugar dessa linha de tensão entre o cuidado como uma categoria tipicamente feminina, invocando, inclusive, a figura da "mãe dos brasileiros" (ibid idem, capítulo 5); ou, na outra ponta, como profissionais que administram eficazmente os dados, técnicas e a ciência em geral do tratamento alopático de saúde.

Assim, as funcionárias da saúde indígena que pendem mais para, por assim dizer, o pólo técnico da linha de tensão, constroem, via de regra, uma relação cotidiana mais distanciada com os Munduruku. Elas estão, com isso, mais suscetíveis a problemas e tensões na convivência diária com os índios - mas são, por outro lado, potencialmente mais bem quistas e quase nunca se indispõem com as pessoas que compõem o corpo burocrático-administrativo das Equipes Multidisciplinares de Saúde (EMSI) de determinado Distrito Indígena.

Por exemplo, pode haver sérias desavenças sobre o controle do uso da cota de combustíveis destinada ao transporte de pacientes das aldeias da região para algum hospital de um centro urbano das proximidades. Os Mundurku, como os Tapayúna, pedem, por vezes, para usar essa cota da saúde para motivos outros sob o argumento de que irão repor esse combustível mais tarde. Entre esses "motivos outros", podemos destacar a ida para algum evento ou festa especial em uma aldeia distante ou então uma viagem para a aldeia Piaraçu, visando pegar o ônibus de linha que passa nessa localidade.

Pelo que notei entre os Tapayúna, as profissionais com mais experiência e capazes de improvisar eficazmente diante de uma situação desse tipo, ou deixavam os 
indígenas usarem a cota, confiando na reposição ou, por vezes, conseguiam que eles mudassem de opinião sobre o uso da gasolina, argumentando não-autoritariamente, a partir de uma relação comum construída em anos de convivência, principalmente com as lideranças da aldeia. Muitas vezes, aquelas que tinham uma relação amistosa com essas lideranças indígenas, nem eram incomodadas em Kawerêtxikô com esse tipo de assunto.

Contudo, existem enfermeiras e técnicas de saúde que não tem tempo ou disposição para construir, gradativamente, relações sociais deste tipo com os índios. No caso dos Munduruku, elas normalmente argumentavam que:

não havia verba, não havia gasolina, não havia motores suficientes, era preciso fazer licitação, não havia como determinar prazos para a chegada dos diversos suplementos e insumos, entre outros, eram limitações concretas transformadas em recursos de autoridade assistencial/administrativa. Esse era um discurso que os profissionais de saúde - fossem enfermeiros ou técnicos em enfermagem - faziam frequentemente $\mathrm{e}$ esperavam que, dessa forma, os Munduruku "entendessem" as justificativas. (ibid idem, :223)

Pode-se perceber, tanto entre os Munduruku como também entre os Tapayúna, que as profissionais com mais tempo de trabalho nas aldeias são aquelas que, primeiramente, conseguiram construir uma relação mais próxima à população atendida, não diretamente relacionada à saúde alopática oferecida no posto-de-saúde. Consequentemente, essa característica garantia que elas se firmassem na função que desempenhavam, já que tinham menos atritos com os indígenas. Pelo que pude perceber, não há nada que mais desagrade os indígenas no uso da saúde alopática disponibilizada na aldeia do que uma novata não-indígena que queira ditar regras.

Nesse contexto de contato com uma outra tradição de organização social, um cientificismo arraigado pode ser outra postura bastante inadequada e potencialmente conflitiva. Já vimos que o corpo, para a medicina alopática moderna, é o mesmo ou similar para índios e não-índios. Partindo dessa premissa, a lógica de parte das funcionárias não-indígenas da saúde é de que não se precisa de tradução para 
trabalhar com um mesmo corpo. Nesse sentido, pode-se ignorar tudo o que é dito pelo paciente ou seu tradutor e se pautar, quando no plantão e trabalhando com a saúde alopática, nas certezas de um corpo comum, cuja lógica de funcionamento já é conhecida de antemão. Por exemplo, em um caso de tratamento específico entre os Munduruku, Silva descreve que

[...] todas as informações transmitidas pelos parentes de Tadeu [a autora usa nomes fictícios] em Munduruku permanecem fora do horizonte da enfermeira. A intervenção da enfermeira ocorre sobre assuntos pautados exclusivamente por ela, segundo as noções de risco e perigo à saúde de Tadeu." (ibid idem :226)

Por outro lado, para os indígenas, os corpos são, inicialmente, diferentes. Há, por exemplo, tanto para os Tapayúna como para os Mebengôkrê, "doenças de branco" e "doenças de índio", como pude notar já nos primeiros dias de meu trabalho de campo. Porém, essas duas noções podem, em contato, transpor corpos de índios e de não-índios. Assim, na visão indígena, é possível que um não-indígena adquira, depois de algum tempo de relação com indígenas, "doenças de índios", como também inversamente. Veremos que, na região Capoto Jarinã, existem diferentes corpos na cosmologia indígena e esses corpos diferentes podem se afetar mutuamente. Assim, o foco não é, nesse caso, em uma pré-natureza estrutural e imutável que é compartilhada de antemão, mas sim em processos complexos de transformação e afetação mútua de corpos que não possuem a mesma estrutura geral - mas que, justamente por isso, se relacionam.

Apesar de seu estudo estar focado na educação formal, Karenina Vieira Andrade também traz informações interessantes sobre a interpretação dos corpos entre os Yekuana (Andrade 2007). Para a autora: “o corpo, aberto, permeável, só pode ser transformado em verdadeiro corpo humano ao longo da vida do indivíduo, através de processos sociais que vão desde ritos de passagem à preparação adequada dos alimentos consumidos." (idem :97). Na Terra Indígena Capoto Jarinã, o que se come, o que se dá para os filhos comerem e o que se compartilha pode mudar a natureza dos corpos. Essa crença não é apenas Tapayuná: ela poder-se-ia chamar 'pan-étnica' já que ela é compartilhada por Mebengôkrê, Tapayúna, Panará e Juruna. 
Deste modo, faço uma breve descrição do contexto específico da sociabilidade interna aldeia Kawerêtxikô, a ser aprofundada no capítulo 4, cujo tema será a terapêutica dos corpos. Pelo que pude notar, há aí uma convivência nem sempre pacífica entre o tratamento alopático não-indígena e a terapêutica desenvolvida pelos Tapayúna e outros grupos. Contrariamente à educação formal onde os professores são geralmente indígenas, na área da alopatia não há oficialmente nenhum operador, nem mesmo em cargos de menor importância, que seja indígena. Os Agentes Indígenas de Saúde (AIS) e os Agentes Indígenas de Saneamento, como mostrarei na conclusão, não são exatamente operadores da saúde alopática. Assim, os índios estão sempre na posição de tratados e nunca na de tratadores. São, com isso, duplamente classificados de forma negativa no tratamento que é dado na "farmácia". Por um lado eles são indígenas e potencialmente não-civilizados; por outro, são sempre "pacientes" de uma terapêutica alopática que, pela sua própria filosofia e organização interna, não tem condições de reconhecer as especificidades culturais indígenas.

Finalizando o presente subtópico, Souza Lima, em trabalho já citado (op. cit), mapeou de maneira exemplar a obrigação principal dos não-indígenas diretamente relacionados com a saúde alopática oferecida às populações indígenas. Segundo esse autor:

O parâmetro utilizado para estabelecer a medida da eficácia, com frequência, foi a capacidade da agência de preservar ou não a vida dos povos indígenas no que se refere à existência biológica $\mathrm{e}$ a evitar massacres e epidemias. Criou-se, aí, a ideia de que intervenções emergenciais e salvadoras configuravam o cerne da vida da instituição. Não importa que na sua ação cotidiana a agência fosse etnocida, isto é, operasse com o objetivo de aniquilar a diferença cultural que justificava a existência mesmo de tal administração: salvar vidas (tal como a administração concebia a vida, no sentido da manutenção da integridade física de indivíduos biológicos, bem entendido) era o que lhe atribuía o mais alto valor e até mesmo as tintas de heroísmo. (idem :38) 
Não é difícil notar que os funcionários da terapêutica alopática estão interessados só indiretamente na sociabilidade dos próprios indígenas. O que conta no bom tratamento alopático dos índios é que seus corpos estejam relativamente saudáveis. Como mostrarei no capítulo 4, mesmo os profissionais de saúde mais experientes podem cair na 'armadilha' da classificação dos indígenas como, ao mesmo tempo, "pacientes" e, ao mesmo tempo, não-totalmente-civilizados. Passemos, então, para o último ponto do presente capítulo: a comparação, ainda que preliminar, entre a saúde e a educação indígenas.

\subsection{Os estudos de educação formal e saúde alopática entre os indígenas em uma perspectiva comparada}

A etnografia sobre educação formal e saúde alopática entre os Tapayúna mostrará alguns temas interessantes de comparação entre essas duas áreas. Por enquanto, focalizarei essa discussão em somente uma dimensão que se mostrou relevante na análise da literatura antropológica sobre essas duas áreas: a participação dos indígenas nesses dois campos.

A comparação entre a educação formal e a saúde alopática indígenas evidencia, inicialmente, uma grande discrepância na participação dessas populações nativas na execução dessas duas políticas. Assim, a atuação oficial de indígenas na área geral do tratamento alopático dos corpos humanos é substancialmente menos frequente do que a participação dos mesmos na educação formal, principalmente nos primeiros anos de ensino, onde há várias centenas de professores indígenas em atuação no Brasil.

Além disso, nos últimos anos, a presença de indígenas no ensino superior tem aumentado sensivelmente e sido tema de análises interessantes como a de Gersem Luciano no artigo intitulado Indígenas no ensino superior: novo desafio para as organizações indígenas e indigenistas no Brasil (Luciano, 2009). É importante lembrar aqui que o Laboratório de Pesquisa em Etnicidade Cultura e Desenvolvimento (Laced), do Museu Nacional da Universidade Federal do Rio de Janeiro (MN-UFRJ), tem tido um papel importante na abertura e, principalmente, na 
manutenção dos alunos indígenas em diversos cursos superiores em todo o Brasil. ${ }^{35}$ Se existem cada vez mais indígenas nas universidades brasileiras, em uma rápida pesquisa pela Internet, nota-se que os indígenas formados em medicina são casos especiais, exceções que confirmam a regra e que viram notícia ${ }^{36}$. Os cursos de graduação em medicina não estão disponíveis para a maioria da população brasileira, o que se dirá para uma minoria étnica que, há poucas décadas, era tratada pelo Estado como portadora de um tipo de sociabilidade ultrapassada e fadada ao desaparecimento, como vimos acima.

Da mesma forma, se já existem pesquisas feitas por indígenas no campo da educação formal, como os casos de Luciano e Benites atestam, o mesmo não acontece na área de saúde indígena. No levantamento que pude fazer, não encontrei nenhum trabalho que seja escrito por indígenas - tanto no campo da análise sociológica de como atua a saúde pública como também no campo específico da terapêutica nãoindígena. No levantamento geral feito por Dominique Buchillet (2006) também não há qualquer indicação de análises com este tipo de autoria, mesmo quando os temas de pesquisa são "xamanismo e sistemas indígenas de saúde", por exemplo.

Essa ausência pode ser explicada pelo caráter mais 'engessado' ou menos 'poroso', típico da medicina ocidental quando comparada à área da educação formal e, por outro lado, pelo já citado caráter secreto do conhecimento xamânico entre diversos grupos indígenas. Como vimos acima, a expertise de médico, através do Conselho Federal de Medicina (CFM), foi a única com condição de barganhar politicamente a possibilidade de uma exclusividade na terapêutica de origem não-

\footnotetext{
${ }^{35}$ Essa centralidade do Laced não está apenas relacionada ao financiamento de uma estrutura para receber, nas instituições de ensino superior públicas e privadas, os alunos indígenas, mas também em uma série de publicações que facilitam a vida acadêmica desses mesmos alunos; essas publicações podem ser facilmente acessadas pela página eletrônica na Internet do Laboratório, no link do Projeto Trilhas do Conhecimento (http://www.trilhasdeconhecimentos.etc.br/, com acesso em 06/03/16). Em outro trabalho, Gersem Luciano (2011 :23-24) faz uma interessante avaliação do Projeto Trilhas do Conhecimento. Eu próprio, durante o mestrado no MN-UFRJ, tive o prazer de trabalhar no referido Projeto.

${ }^{36}$ Conferir, por exemplo a notícia do primeiro indígena formado em medicina na Universidade de Brasília, no ano de 2013: http:/g1.globo.com/distrito-federal/noticia/2013/02/1-medico-indigena-daunb-diz-que-se-sentia-estranho-entre-intelectuais.html; ou, ainda, o primeiro indígena formado pela Universidade Estadual de Maringá, em 2015: http://flacso.org.br/?p=13759; ou, para dar um último exemplo, o primeiro indígena, nesse caso uma mulher, formada na Universidade Federal do Rio Grande do Sul, também em 2015: http://diariogaucho.clicrbs.com.br/rs/dia-adia/noticia/2015/06/diploma-ecoa-na-aldeia-medicina-da-ufrgs-forma-a-primeira-cotista-indigena4785525.html; os acessos aconteceram em 25/02/16. É importante notar que todos os graduados em medicina, nas três reportagens, entram em seus respectivos cursos por alguma reserva de vagas de determinado sistema de cotas especiais para indígenas.
} 
indígena. Seriam, assim, esses profissionais os únicos legítimos a poder adentrar o corpo humano e, portanto, preparar diagnósticos de saúde. O Ato Médico passou pelas duas casas do Parlamento brasileiro e chegou com essas características para o veto ou sanção da presidente. Contudo, a junção de todos os especialistas de outras áreas afetadas por tal tentativa de regulamentação, relacionados ou não a algum tipo de tratamento de saúde, bem como o impacto desse projeto de lei na terapêutica oferecida pelo Estado brasileiro, fez com que Dilma Rousseff o vetasse parcialmente, principalmente os artigos mais polêmicos que teriam influência direta nas políticas públicas de saúde do Sistema Único de Saúde (SUS) e, portanto, também nas aldeias indígenas. O Conselho Federal de Medicina, é claro, foi contrário ao veto e insistiu, sem sucesso, que o Parlamento o derrubasse, sob o argumento de que o poder público não queria gastar mais dinheiro para oferecer um tratamento público de saúde com maior qualidade para a população que faz uso do $\operatorname{SUS}^{37}$.

Situação bem diferente pode ser encontrada na educação formal, principalmente naquela oferecida aos indígenas. Além de centenas de professores indígenas que atuam nas escolas, já existem importantes estudos feitos pelos próprios indígenas nessa área. Embora ainda raras, a existência de etnografias sobre educação formal escritas pelos próprios indígenas me parece um ponto importante. Esses trabalhos também começaram a estimular o debate antropológico que percebe nessas pesquisas etnográficas realizadas por indígenas um enriquecimento da própria antropologia.

Em um artigo publicado em 2007, Alcida Rita Ramos já tratava da possibilidade de surgimento de "auto-etnografias" entre os indígenas no Brasil (Ramos, 2007). Nesse texto, além de argumentar sobre a impossibilidade ética e política de se fazer um trabalho etnográfico baseado unicamente na virtual ausência do etnógrafo da narrativa, nos moldes de Bronislaw Malinowski (1976), ela também diferenciou entre "etnografias metonímicas", "etnografias nativas" e "autoetnografias". Segundo a autora, as duas primeiras teriam os mesmos moldes acadêmicos das tradicionais etnografias dos estudiosos dentro da Antropologia Ocidental, contando apenas com a característica de que o observador faz parte do grupo observado. Já a última, por sua aplicação estritamente política, poderia

37 Conferir, por exemplo, a reportagem da EBC no link: http://www.ebc.com.br/noticias/saude/2013/07/cfm-diz-que-vetos-sao-agressao-e-traicao-aos-medicos, com acesso em 06/03/16. Fica claro, aí, o descontentamento da categoria médica com o veto presidencial. 
subverter esses moldes, podendo chegar mesmo a não ser reconhecida como uma etnografia strictu sensu (Ramos, op. cit, :23 e subsequentes).

Levando tal argumento em consideração, a primeira impressão é que os trabalhos citados de Luciano e Benites poderiam ser mais facilmente classificados como "etnografias metonímicas" do que propriamente como "auto-etnografias". Eles possuem uma fineza interpretativa e rigor metodológico que são típicos dos centros de excelência em que foram produzidos - respectivamente, o Programa de PósGraduação em Antropologia Social da Universidade de Brasília e o Museu Nacional da Universidade Federal do Rio de Janeiro. Contudo, como visto, esses antropólogos indígenas também precisam dialogar e apresentar resultados positivos para suas comunidades de origem. Assim, as fronteiras entre as duas categorias de etnografia de Alcida Rita Ramos acabam por 'amalgamar-se': não há como um indígena produzir uma etnografia completamente baseada na produção e circulação de conhecimento que são típicos de sua etnia e, ao mesmo tempo, ser aceito sem nenhum problema dentro dos rígidos dogmas da academia; da mesma maneira, a comunidade e o movimento propriamente indígena organizado que deram condições para que os etnógrafos nativos fizessem análises sobre seus próprios povos também não aceitarão um trabalho completamente descontextualizado daquela tradição da qual o "autoetnógrafo" advém. Essa constatação, se não está explícita, ao menos pode ser sugerida a partir da leitura do instigante artigo de Gallois et alii (2016).

Os profissionais indígenas que trabalham na área da educação formal normalmente começaram a lecionar antes mesmo de completar um curso específico que legalmente os habilitasse à docência. Esse é o caso, por exemplo, de Orengô Tapayúna, um dos professores da Escola Goronã da aldeia Kawerêtxikô. Assim como Benites e Luciano, que também foram professores em suas respectivas comunidades de origem, Orengô começou a alfabetizar as crianças de seu povo antes de terminar o curso de ensino médio de magistério indígena, frequentado parcialmente em uma das cidades das redondezas e, parcialmente, na aldeia mebengôkrê de Piaraçu. Nessa época, Orengô e os Tapayúna viviam, ainda, na aldeia do Metyktire ${ }^{38}$. Não tinham, ainda, fundado Kawerêtxikô, mas já tentavam alfabetizar suas crianças na língua

\footnotetext{
${ }^{38}$ O próximo capítulo é dedicado a perfazer a história do contato dos Tapayúna.
} 
Kaykwakhratxi ${ }^{39}$. Ressalto, aqui, que até o momento apenas um tapayúna tem curso superior: Wengroi. Durante meu período de campo, ele cursava os últimos semestres da graduação em Pedagogia. Formado, Wengroi ocupa hoje o cargo de diretor da Escola Goronã. No presente ano, Orengô foi selecionado para cursar a faculdade de pedagogia.

Por outro lado, não tive contato com nenhum profissional da área da saúde pública, dentro ou fora das aldeias, que não tivesse como formação básica ao menos o curso técnico de enfermagem. Nenhum Tapayúna possui essa formação; do mesmo modo, nenhum dos Mebengôkrê que conheci.

Há uma correlação ainda não explorada entre esses professores indígenas e o ofício dos antropólogos. Por exemplo, Orengô e Wengroi foram os meus mais profícuos contatos para conseguir informações sobre o funcionamento da educação formal na aldeia Kawerêtxikô. Como vimos, Tonico Benites, em sua dissertação de mestrado, ressaltou que foi informante de diversos antropólogos e que era o tradutor das lideranças de seu povo para o Português (op. cit., :11). Apesar de não dizer ter sido tradutor ou informante entre os Baniwa, Gersem Luciano classificou assim sua experiência inicial de letramento em uma escola católica:

nunca imaginei que um dia poderia conhecer uma boa parte do mundo branco. Meu principal sonho era aprender coisas dos brancos na escola e um dia poder ter algumas coisas simples, como pão, biscoito, roupa, relógio e ser professor da minha comunidade. (op. cit. :17).

No que toca à saúde oferecida pelo Estado aos indígenas, como já dito, não há sinal de um protagonismo indígena a ser notado. Meus contatos diretos foram sempre com técnicas em saúde e enfermeiras, mais cotidianamente; e médicos e dentistas, nos momentos em que esses últimos visitavam a aldeia Kawerêtxikô. No máximo, tive condições de etnografar as relações entre todos esses profissionais de saúde e seus pacientes tapayúna - ou, como fez Cristina Dias (op. cit.), as relações internas entre os diferentes não-indígenas envolvidos com a saúde alopática. Como dito, a condição de

\footnotetext{
${ }^{39}$ Há de se notar a excelente assessoria que a Fundação Nacional do Índio (Funai), na figura da funcionária Maria Eliza Leite, prestou aos grupos de língua Jê da região, pontualmente os Panará, Mebengôkrê e Tapayúna, na feitura desses manuais de alfabetização na língua nativa (cf. Introdução).
} 
"paciente" não revela uma agência particular, ao menos quando vista sob a ótica do tratamento alopático.

Como veremos no capítulo 4, as interações entre o conhecimento terapêutico do xamã de Kawerêtxikô, por exemplo, ou o conhecimento de cura não-alopático do Agente Indígena de Saúde (AIS), com a medicina alopática sempre se deu, entre os Tapayúna, de maneira mais ou menos tensa ou agonística - e, é claro, também assimétrica. Antes de descrever e analisar essas relações conflituosas farei, no próximo capítulo, um breve histórico dos Tapayúna, desde a expulsão do seu território tradicional, passando pelo contato com os não-indígenas até a fundação da aldeia Kawerêtxikô. A descrição desse histórico também me dará a oportunidade de apresentar e discutir as relações dos Tapayúna com seus outros, sejam eles indígenas ou não. 


\section{Capítulo 2. Os Tapayúna e os outros: relações interétnicas no Xingu}

No presente capítulo, pretendo apresentar brevemente a história dos Tapayúna (Kaykwakhratxi) da aldeia Kawerêtxikô e suas relações com os não-indígenas e os indígenas que vivem na região. Começarei pela invasão e tentativa de genocídio sofridas pelos últimos em seu território tradicional. Assim, mostrarei a migração forçada deles para o Parque Indígena do Xingu (PIX). Inicialmente, os Tapayúna encontraram refúgio entre os Suyá (Kinsedje) e, mais tarde, entre os Kayapó (Mebengôkrê). O tema central do capítulo será a contextualização dos Tapayúna da aldeia Kawerêtxikô e suas relações com os outros povos indígenas que habitam a Terra Indígena Capoto Jarinã, no PIX, ou seja, os Mebengôkré, os Panará e os Yudjá. Para tanto, demonstrarei a existência, nesse contexto indígena regional, de certa hegemonia política dos Mebengôkrê. Tal hegemonia relativa pode ser entendida a partir da análise das relações entre esses diferentes povos que se organizaram para a tomada e a gerência da balsa de automóveis sobre o rio Xingu, local onde a antiga rodovia BR-080, atual MT 322, corta a Terra Indígena Capoto Jarinã.

Antes de iniciar essa descrição e análise, cabe informar o leitor sobre a literatura antropológica e as categorias usadas para fazer referência ao contato entre grupos indígenas e não-indígenas com línguas e tradições sociais diferentes. Dois clássicos da antropologia me ajudaram a pensar as identidades e fronteiras entre os grupos humanos: o estudo de Fredrik Barth sobre a construção cotidiana e porosidade das fronteiras étnicas (Barth, 2000); e a etnografia de Evans-Pritchard sobre os diferentes graus identitários que podem ser acionados por determinada pessoa em determinada situação social (Evan-Pritchard, 2013).

No Brasil, existe uma tradição importante nos estudos de contato entre povos indígenas e não-indígenas. Historicamente, esse tema tem recebido um interesse central na etnologia, sendo, para alguns autores, uma marca da própria etnologia brasileira (Ramos 1990; Peirano 1999). Inicialmente orientado pelos estudos de aculturação, que dominaram a etnologia nas décadas de 1940 a 1960, (Schaden, 1964, Galvão 1979), o contato entre índios e não-índios encontrou uma nova dinâmica com a noção de "fricção interétnica", cunhada por Roberto Cardoso de Oliveira (Cardoso de Oliveira [1964] 1972), e que se tornou o principal paradigma nas décadas de 1970 e 80. Nas últimas décadas, uma grande diversidade de estudos etnográficos, a partir de 
diversas abordagens teóricas, vieram se somar e enriquecer a compreensão dos fenômenos resultantes do contato entre povos indígenas e não indígenas no Brasil. ${ }^{40}$ Dentro dessa ampla literatura que aborda o contato interétnico, é importante esclarecer o sentido que eu dou à noção de relações interétnicas.

A obra Hierarquia e simbiose: relações intertribais no Brasil, organizada por Alcida Ramos (1980), pode ser considerada um desdobramento dos estudos orientados pela noção de "fricção interétnica". Os artigos que compõem essa coletânea discutem não só as relações entre indígenas e não-indígenas, mas também entre povos indígenas diferentes, o que é bastante útil para entender as relações entre os diferentes grupos indígenas que habitam a Terra Indígena Capoto Jarinã, principalmente, como veremos, a partir da noção de "simbiose". Cabe notar, no entanto, que nesse livro Alcida Ramos estabelece uma diferenciação entre as "relações interétnicas", isto é, as relações entre povos indígenas e segmentos da sociedade nacional não-indígena, e as "relações intertribais", ou seja, as relações entre povos indígenas diferentes (idem Introdução). Essa distinção da autora retoma uma diferenciação bastante comum e pouco questionada na história da etnologia indígena brasileira. Em Sociologia do Brasil indígena (1978:12 e subseqüentes), Roberto Cardoso de Oliveira, por exemplo, também apresentou essa diferença embora, no prefácio à coletânea organizada por Ramos, esse mesmo autor tenha explicado que “interétnico" era uma categoria que 'englobava' a noção de "intertribal”, deixando entender que as relações entre povos indígenas são somente uma especificação dentro da ampla categoria de relações "interétnicas" (Cardoso de Oliveira, 1980).

Deste modo, gostaria de salientar que, quando usar o termo "interétnico" ao longo deste trabalho, estarei me aproximando desse uso mais genérico, ou seja, ao utilizar esse termo também englobo as relações geralmente qualificadas de “intertribais”, por exemplo, no estudo já citado de Alcida Rita Ramos. Isso não significa que não exista uma diferenciação entre as relações entre povos indígenas e as relações entre indígenas e não-indígenas. Apresentarei, ao longo deste capítulo, exemplos que evidenciam claramente essas diferenças. No entanto, considero que as relações interétnicas podem dar conta tanto do contato entre grupos auto-denominados e referidos como indígenas e, também, das relações de indígenas com comunidades

\footnotetext{
${ }^{40}$ Não cabe mencionar aqui a grande diversidade de etnografias produzidas nas últimas décadas que abordam as relações entre povos indígenas e não-indígenas no Brasil. Como exemplo, citarei somente a coletânea organizada por Albert e Ramos (2002).
} 
regionais não-indígenas que circundam ou estão de passagem pela região. A minha preferência pelo termo "interétnico" em detrimento de "intertribal" também permite diferenciar o contexto etnográfico das terras baixas da América do Sul do Continente Africano onde o termo "tribal" pode aludir a uma centralização de população e poder político dentro de uma mesma tradição linguística e social, características ausentes na nossa realidade. Roberto Cardoso de Oliveira já fazia referência à necessidade de contextualização dessas peculiaridades dos contextos etnográficos nativos entre os Continentes Africano e Sul-Americano na introdução da obra já citada (Cardoso de Oliveira, 1978).

Adianto que a etnografia que se segue tem como base os dados de campo que recolhi na interação com os Tapayúna da aldeia Kawerêtxikô durante 13 meses de trabalho de campo não-consecutivos. Os mapas e dados de geoprocessamento foram conseguidos juntos às páginas eletrônicas na Internet da Funai e do Instituto Brasileiro de Geografia e Estatística (IBGE). A referência completa é dada no final de cada um dos mapas. É importante esclarecer que não é minha intenção fazer um apanhado exaustivo da história de montagem e configuração do PIX. Uma minuciosa e excelente análise do processo de criação do PIX, relacionada com o contexto histórico e político brasileiro, foi feita, por exemplo, por Menezes (2000). O meu objetivo aqui é relacionar a história geral desse Parque com a história mais específica dos Tapayúna com o intuito de apresentar ao leitor a atual configuração social e política da região em que se encontra a aldeia Kawerêtxikô.

Para tanto, começo por descrever o contato dos Tapayúna com os não indígenas durante o processo de colonização de suas terras tradicionais que levou a fuga desse povo para o PIX. Em seguida, analiso as relações dos Tapayúna com os Kinsedje e, posteriormente, com os Mebengôkrê com os quais os Tapayúna da aldeia Kawerêtxikô, foco deste trabalho, passaram a conviver dentro da Terra Indígena Capoto Jarinã antes de fundar sua própria aldeia. Por fim, termino examinando as relações interétnicas em torno da distribuição do dinheiro oriundo de um sistema de pedágio instalado no local onde a atual rodovia MT 322 (antiga BR 080) atravessa o rio Xingu. A travessia desse rio se faz por meio de uma balsa que é controlada pelos Mebengôkrê da aldeia Piaraçu. Todos os não-indígenas que precisam atravessar o Xingu devem pagar o pedágio. O dinheiro recolhido é, em seguida, distribuído nas aldeias. Além de trazer um aporte não negligenciável de recursos financeiros para os 
índios, esse sistema oferece uma oportunidade privilegiada para compreender as relações interétnicas no interior da Terra Indígena Capoto Jarinã.

\subsection{Os primeiros contatos dos Tapayúna com os não-indígenas e a fuga para o PIX}

No primeiro capítulo do Almanaque Parque Indígena do Xingu - 50 anos (ISA, 2011) argumenta-se que:

O Parque significou a delimitação de um espaço privilegiado e incontestável de proteção para as etnias que lá viviam e para aquelas que viviam ameaçadas na sua circunvizinhança e que para lá foram levadas pelos irmãos Villas Bôas, algumas debilitadas, com um quadro drástico de redução populacional, à beira da extinção. (idem: 21).

Os Tapayúna da aldeia Kawerêtxikô (Mapa 01) foram um dos povos obrigados a migrar de suas áreas tradicionais para compor o mosaico interétnico atual de 16 povos do PIX. Como bem coloca a narrativa do Instituto Sócio-ambiental (ISA), diversos grupos chegaram ao Parque bastante debilitados e só fizeram a viagem de suas terras para esse novo local para não desaparecer por completo. Tal mudança foi impelida, sem dúvida, pelos projetos de "ocupação" dos estados de Goiás e Mato Grosso durante a gestão de Getúlio Vargas no Estado Novo, que considerava essas áreas como perigosos "vazios demográficos" que precisavam ser urgentemente preenchidos (Maia, 2010). 


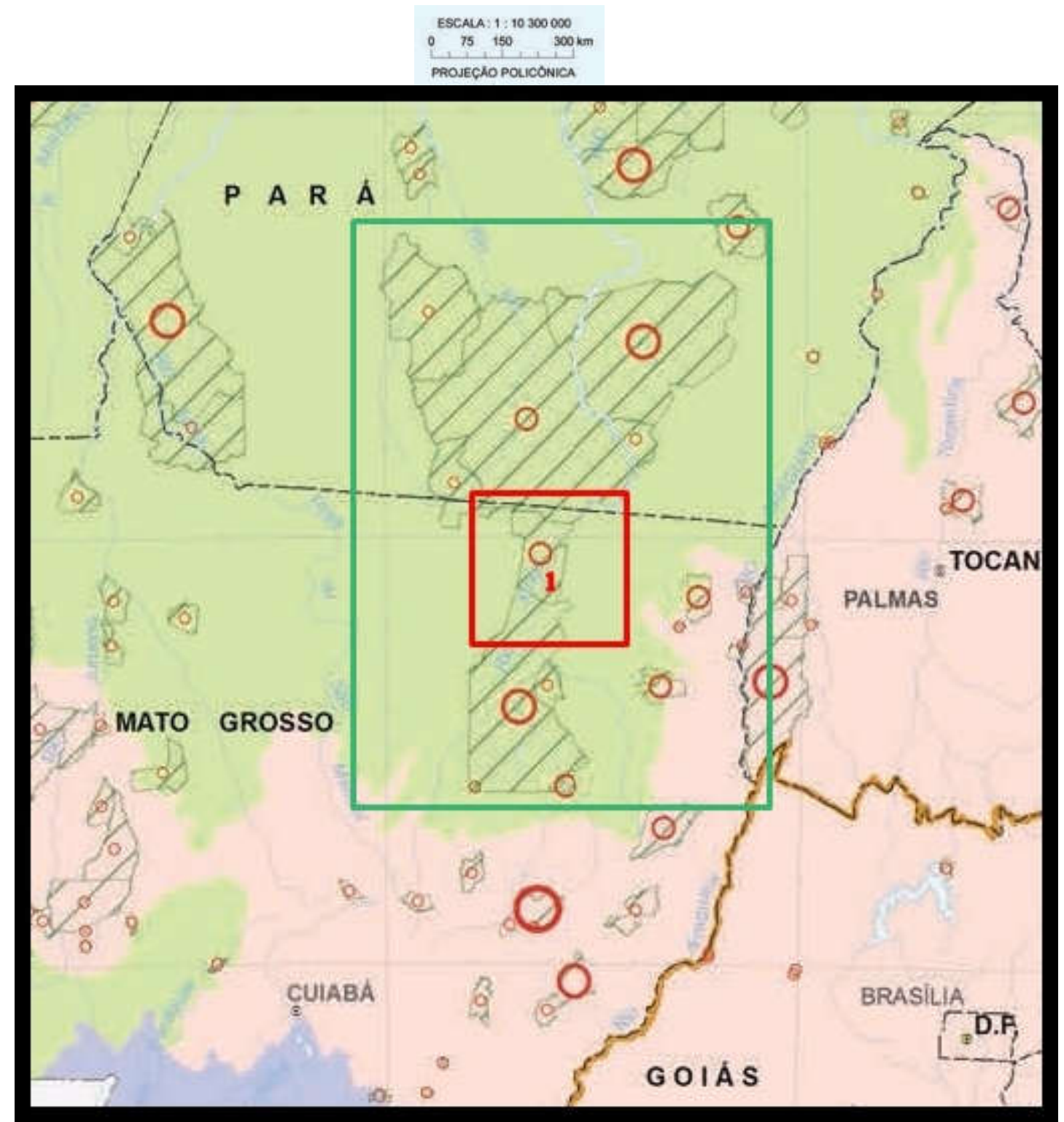

Mapa 01: Localização da aldeia Kawerêtxikô (n. 1, em vermelho). O Parque Indígena do Xingu é a grande área delimitada pelo retângulo verde. $\mathrm{O}$ retângulo pequeno menor, em vermelho, delimita a Terra Indígena Capoto Jarinã. Os círculos em vermelho são do mapa original e fazem referência à quantidade de habitantes indígenas na região: os maiores representam uma população de 3001 a 6000 pessoas; os intermediários, de 1001 a 3000; os menores, até 1000 pessoas.[Fonte: Adaptado pelo autor diretamente do Censo Indígena do IBGE. Disponível em ibge.gov.br, com acesso em 15/09/15.]

Depois do Golpe de Estado de 1964, que tirou o presidente João Goulart do poder e instituiu um novo regime militar no país, os limites do então Parque Nacional do Xingu (futuro PIX) foram mudados para permitir a passagem da rodovia federal BR 080. Com isso, uma vasta área do centro do Parque, região tradicional dos povos conhecidos como Kayapó, foi excluída para a construção da referida rodovia no ano de 1971. Em 1984, os Mebengôkrê (autodenominação dos Kayapó) retomaram essa 
área com ajuda de outros indígenas e o apoio de instituições indigenistas e a região passou a ser conhecida como Terra Indígena Capoto Jarinã (ISA op. cit. :47). Foi nesta área que foi fundada, já no século XXI (2006), a aldeia Kawerêtxikô dos Tapayúna, que conta hoje com cerca de 150 pessoas.

Contudo, até a criação de uma aldeia própria, os Tapayúna passaram pelos mais diversos percalços, que levaram à quase extinção do grupo. A antropóloga Daniela Batista de Lima, em dissertação de mestrado orientada por Marcela Coelho de Souza (Batista de Lima, 2012), analisou parte desse processo. ${ }^{41}$ Em seu estudo, ela identificou a chegada da empresa Colonizadora Noroeste Matogrossense Ltda (Conomali) ao Mato Grosso como a primeira responsável pelos primeiros contatos regulares dos "Beiços-de-pau"42 com os não-indígenas nos anos de 1950-1960 (idem $: 50)$.

A Conomali tem sua origem no Grupo Mayer, uma empresa de família e capital privado, montada no Rio Grande do Sul para participar da colonização do Mato Grosso e Goiás. ${ }^{43}$ A estruturação dessa companhia se deu na primeira metade da década de 50 durante o governo eleito de Getúlio Vargas. Ela se constituiu numa corporação que teve como objetivo a compra, com dinheiro próprio, de uma grande porção de terras no norte do Mato Grosso e o fomento à ida de colonos gaúchos, entre outras populações não-indígenas do Sul do Brasil, para ocupar o "vazio" matogrossense na primeira metade dos anos 50 . Na Internet, existe uma página eletrônica, montada pelo repórter da primeira expedição da Conomali, que conta os detalhes da empreitada "heróica". ${ }^{44}$ Sobre os preparativos para receber as primeiras famílias de colonos rio-grandenses, catarinenses e paranaenses na região tradicional dos Tapayúna, argumenta-se que:

cabe aqui lembrar que todo o empreendimento de implantação de um núcleo colonial no norte de Mato

\footnotetext{
${ }^{41}$ Daniela Batista de Lima realiza atualmente o doutorado em antropologia no PPGAS da UnB, orientada por Marcela Coelho de Souza, e tem sido uma interlocutora importante.

42 Os Tapayúna ficaram regionalmente conhecidos como "Beiços-de-pau" em razão do tradicional bodoque que os homens usavam no lábio inferior, que hoje está praticamente em desuso.

${ }^{43}$ Existem outras empresas montadas no mesmo período que fundaram outros núcleos populacionais não-indígenas no norte do Mato Grosso. Como mais um exemplo, cito a cidade norte-matogrossense de Colider, a única da região que tem pista de pouso para aviões comerciais. Colider, como Conomali, era o nome da empresa colonizadora que efetivamente invadiu, ou em termos eufêmicos, 'colonizou' a região.

${ }^{44}$ Ver: http://www.conomali.com.br/index, com acesso em 08/01/15.
} 
Grosso, nos idos de 1955, foi assumido inteiramente pelo Grupo Mayer através da Conomali, por conta, risco e capital próprio, sem qualquer ajuda oficial ou de terceiros. (idem: Cronologia/1955)

Ao se referir à invasão das terras tapayúna, o padre João Evangelista Dornstauder, coordenador da parte cristã-católica da empreitada ainda na década de 50, afirma que "o Dr. Gustavo Isernhagen [engenheiro contratado pela Conomali] fora flechado no pescoço, pelos Beiços-de-Pau, em viagem pelo Arinos, sofrendo forte hemorragia. Agora impera a ira contra o índio, qualquer que seja" (idem :Cronologia/Os Nativos).

Toda a narrativa da página eletrônica tem o tom romântico do desbravamento de uma terra sem dono, de maneira bastante similar àquela citada por João Marcelo Ehlert Maia no estudo da burocracia estatal do Estado Novo (Maia, op. cit.). Na descrição do repórter Walter Irgang não se identifica qualquer problema ou contradição na descrição do "vazio populacional" e as constantes refregas com os Beiços-de-Pau, os Rikbáktsa ou os Kaiabis, habitantes ancestrais da região.

Há dois relatos de casos exemplares de como a população não-indígena trazida pela Conomali tenta lidar com os já ocupantes da região. Em um primeiro relato, um grupo de trabalhadores da empresa, depois de ter sido atacado à flechadas pelos Beiços-de-Pau, solicita providências do Serviço de Proteção ao Índio e Localização de Trabalhadores Nacionais (SPI/LTN) de Cuiabá. São escalados, então, alguns funcionários do órgão para assessorar o pessoal da Conomali. Porém, os funcionários do SPI/LTN se recusam a fazer a viagem, temendo a violência dos nativos da região. Assim, o mesmo grupo de "desbravadores" da Conomali recorre ao Exército "que os abasteceu com armamentos para se defenderem contra os índios" (Batista de Lima, op. cit. :57). Em um outro caso, não-indígenas deixaram, inicialmente, na mata, uma porção de açúcar envenenado com arsênico para os Tapayúna comerem. Depois disso, nos mesmos moldes, usaram veneno para baratas, que foi colocado em carne de anta e deixado numa trilha usada pelos índios. As duas ações criminosas causaram mortes entre os chamados Beiços-de-pau, mas nenhuma conseguiu dar cabo deles por completo (idem :50-60). 
A altivez dos índios foi quebrada de uma maneira relativamente inesperada, ao menos para os colonos e funcionários da Conomali que sofriam com seus ataques regulares. No ano de 1968, um repórter gripado que acompanhava um grupo de funcionários da Funai causou uma grave epidemia da doença entre os Tapayúna, que viram sua população reduzida a cerca de 40 indivíduos. As estimativas, a partir de sobrevôos de avião, contavam algo em torno de 1200 pessoas antes da epidemia (ibid idem :72). Batista de Lima, a partir de entrevistas com os sobreviventes traduzidas por Marcela Coelho de Souza, informa que:

Como sinal de luto os índios queimaram as antigas aldeias, e jogaram fora suas armas. A partir de então, foram levados pelos missionários para um novo local no rio Parecis, e lá construíram cabanas para que os índios ficassem alojados. Permaneceram aí, plantaram roças até serem transferidos para o Parque do Xingu [PIX]." (ibid idem :73)

O homem que me deu o nome de "Tihoktxi"45 e se tornou meu pai classificatório foi um dos sobreviventes dessas tentativas de envenenamento e da epidemia de gripe. Ele morreu, com cerca de 80 anos, em 2014 e era o único tapayúna que ainda conservava o "Beiço-de-pau". A esposa atual do pajé Wotkàtxi, na aldeia Kawerêtxikô, é outra sobrevivente desses trágicos eventos. Eu e a linguista Nayara Camargo, durante o final do ano de 2012, entrevistamos ela e meu pai classificatório no intuito de produzir a primeira listagem dos mortos dessas ocasiões (Anexo 01).

\subsection{O convívio dos Tapayúna com os Kinsedje}

O estudo já citado de Batista de Lima traz depoimentos importantes dos sobreviventes da epidemia de gripe. Do mesmo modo, mostra também como os

\footnotetext{
45 "Tiho" quer dizer círculo; "txi” é uma categoria que designa o aumentativo. " Tihoktxi” significa aproximadamente o grande círculo central de uma aldeia, em Kaykwakhratxi.
} 
Tapayúna foram inicialmente levados a viver junto aos chamados Suyá - os Kinsedje, do mesmo tronco e família lingüística dos Tapayúna e, possivelmente, contando com um passado em comum com esses, como argumenta o estudo da lingüista Nayara Camargo:

Em um momento ainda não bem determinado, um subgrupo Suyá, também referido como Suyá Oriental, seguiu para o leste, descendo o rio Ronuro até o território da atual Terra Indígena do Xingu [PIX], passou pelo Alto (região dos formadores do rio Xingu) e se estabeleceu posteriormente no rio Suyá Missu.

O outro subgrupo, conhecido como Suyá Ocidental (também chamados de Tapayúna, Suyá Novo ou Beiços de Pau) permaneceu na região do rio Arinos e rio Sangue. (Camargo, $2010: 31$ )

Depois da epidemia de gripe, todos os Tapayúna sobreviventes saíram de sua região tradicional (rio Arinos e rio do Sangue) e foram convencidos por missionários católicos a viver junto aos Kinsedje, agora já dentro dos limites do PIX. Padre Iasi, um desses missionários, conseguiu tal feito mostrando gravações de áudio de músicas Kinsedje aos Tapayúna, que logo reconheceriam o parentesco lingüístico entre eles (Batista de Lima, op. cit. :105 e subseqüentes). A partir daí, os Tapayúna começariam - ou voltariam - a se relacionar com os Kinsedje.

No meu contato pessoal com os Kajkwakhratxi (autodenominação dos Tapayúna) tive a oportunidade de recolher relatos sobre a relação passada entre eles e os Kinsedje, além dos motivos que os levaram a se mudar para junto dos Mebengôkrê. Tais temas são também tratados por Batista de Lima (op. cit.), mas a partir da fala daqueles que permaneceram entre os Kinsedje e não se aventuraram na Terra Indígena Capoto Jarinã dos Kayapó.

Conheci, assim, Werantxi, um dos filhos da liderança Tapayúna Wekôrô, liderança que foi morta por guerreiros Kinsedje sob a acusação de feitiçaria, o que motivou a mudança dos Tapayúna para junto dos Mebengôkrê, agora já dentro da 
Terra Indígena Capoto Jarinã. O filho de Tariri (nome pelo qual era conhecido Wekôro entre os não-indígenas) casou-se com uma mulher Mebengokrê e vive hoje fora da aldeia Kawerêtxikô, mas nas proximidades desta, na aldeia mebengôkrê de Kromari. De todo modo, ele visita regularmente sua mãe, a viúva de Tariri, senhora de idade que reside ainda entre os Tapayúna de Kawerêtxikô. Werantxi viajou para a cidade de São José do Xingu nos últimos dias do mês de fevereiro de 2014. Orengô, um dos professores da Escola Goronã de Kawerêtxikô, nos apresentou e eu the encomendei alguns produtos da cidade. Durante esse encontro com Werantxi, ao falar sobre seu pai e a relação com os Kinsedje, não percebei qualquer sinal de vitimização por parte dele ou de sua mãe, Ngejmontxi. O filho de Tariri, que fala razoavelmente bem o Português, não fez sequer uma menção negativa aos Kinsedje e nunca se colocou numa posição de vítima.

É preciso esclarecer aqui que a morte de Wekôrô foi um infortúnio cuja explicação remonta às comuns acusações de feitiçaria entre grupos que se qualificam como distintos um dos outros, mas que passam a ter que ocupar a mesma região geográfica, normalmente por pressão de não-indígenas. Os Kinsedje atribuíram a morte de Petxi, um indígena desse grupo, a ações de feitiçaria. Fatalmente, essas acusações recairiam sobre os estrangeiros recém-chegados ao território Wawi, ou seja, os Tapayúna. Assim, a vingança da morte do índio kinsedje Petxi por feitiçaria acabou se desdobrando na morte de um índio tapayuna: Wekôrô ou, como era conhecido entre os não-indígenas, Tariri. Este último era uma liderança bastante conhecida por seu trânsito entre os não-indígenas e pelo respeito que tinha entre seus pares. Os Tapayúna de Kawerêtxikô dizem que Tariri era uma espécie de cacique e aconselhador entre eles. Depois de sua morte, a maioria dos Tapayúna gradualmente migrou do Wawi, região dos Kinsedje contígua ao PIX, para a Terra Indígena Capoto Jarinã, tradicional território dos Mebengôkrê.

Atualmente, a relação entre os Tapayúna de Kawerêtxikô e os Kinsedje parece estar sendo paulatinamente retomada. Em 2014, foi organizada uma comitiva de homens Tapayúna de Kawerêtxikô para dançar e prestigiar a festa de formatura de curso superior de Yaiku, uma liderança Kinsedje, mas filho de mãe tapayúna. No mesmo ano, os Tapayuna de Kawerêtxikô receberam parte de uma família residente entre os Kinsedje, mas que tinha parentes na aldeia tapayúna. Assim, dois jovens homens, a mãe deles e uma irmã estão, atualmente, residindo nessa última aldeia de 
forma amistosa e pacífica, sem qualquer evocação, até onde pude perceber, dos fatos ocorridos anteriormente, na época da residência dos Tapayúna entre os Kinsedje.

Contudo, depois da separação, o trato geral entre os dois grupos nem sempre se deu em bases amigáveis. Por exemplo, Daniela Batista de Lima e eu fomos envolvidos em um imbróglio no qual tínhamos muito pouca possibilidade de agência. Batista de Lima fez sua dissertação de mestrado entrevistando pessoas que residiam na região do Wawi, junto aos Kinsedje, sob o intermédio e assessoria da liderança kinsedje Yaiku. Além disso, como já dito, ela foi orientada por Marcela Coelho de Souza, que pesquisa este último grupo e que traduziu as entrevistas em língua nativa para Daniela Batista de Lima. Deste modo, Batista de Lima foi temporariamente identificada, pelos Tapayúna que já residiam em Kawerêtxikô, como uma nãoindígena apoiadora dos Kinsedje. Nessa época, eu fazia os primeiros meses de pesquisa de campo na aldeia tapayúna e acompanhei esse mal entendido: em meados de 2013 as lideranças de Kawerêtxikô pediram que eu avisasse Daniela Batista de Lima que ela, como amiga dos Kinsedje, não era bem vinda à Kawerêtxikô.

Nesse contexto, um projeto de pesquisa para os Tapayúna, com verba internacional, negociado e gerido por Daniela Batista de Lima e Yaiku, mas levando o nome dos Tapayúna em geral, foi objeto de muita polêmica e discussões. As lideranças de Kawerêtxikô exigiam que parte dos bens conseguidos por esse projeto ficasse entre os Tapayúna de Kawerêtxikô - e não somente com aqueles que permaneceram entre os Kinsedje, como até então acontecia. Nokêrê Tapayúna, entre outras lideranças, na época de vigência desse imbróglio, era enfático em afirmar que Tapayúna eram apenas os que haviam se mudado para a área Capoto Jarinã e fundado sua própria aldeia. Os outros, muito dos quais não se mudaram pois haviam casado e tido filhos entre os Kinsedje, não deviam, em sua visão, se auto-identificar como Tapayúna. Depois de uma longa negociação, parte do material adquirido com o dinheiro do projeto ficou com os Tapayúna que ainda residiam entre os Kinsedje (um barco e um motor de popa) e outra parte (uma filmadora profissional, um notebook e um motor-gerador de energia elétrica à gasolina) foi levada aos Tapayúna que haviam se mudado para a Terra Indígena Capoto Jarinã. Enquanto escrevo essas linhas, Daniela Batista de Lima está fazendo trabalhado de campo em Kawerêtxikô sem maiores problemas e com total anuência das lideranças Tapayúna da região. 
Um dos motivos pelos quais os Tapayúna de Kawerêtxikô me chamaram para realizar pesquisa entre eles foi justamente o fato da antropóloga Daniela Batista de Lima ser classificada, como dito, como muito próxima à Yaiku e, consequentemente, aos Kinsedje. Assim, os Tapayúna de Kawerêtxikô procuravam um antropólogo que tivesse como raízes e campo exclusivo de pesquisa a aldeia recém-fundada na Terra Indígena Capoto Jarinã.

Além disso, havia pouco tempo que os Panará tinham conseguido uma indenização financeira por genocídio e os Tapayúna de Kawerêtxikô também queriam, com a ajuda desse antropólogo, pleitear uma compensação pelo genocídio que haviam sofrido. Como descrito na introdução, foi nesse contexto que fui chamado, durante um curso de formação de professores indígenas da Funai no qual trabalhava nos últimos meses de 2012, a pesquisar entre os Tapayúna. O receio maior dos índios Kawerêtxikô era que o pedido de indenização fosse feito pela minoria numérica que vive entre os Kinsedje, com o assessoramento da antropóloga Daniela Batista de Lima e da liderança Yaiku. De todo modo, atualmente os Kaykwakhratxi residentes em Kawerêtxikô se convenceram da possibilidade de dois antropólogos pesquisarem, ao mesmo tempo, sua aldeia, cada um com sua pauta de pesquisa. Gradualmente, eles aceitaram a presença de Daniela Batista de Lima com o argumento que ela e eu apresentamos: eles seriam melhor assessorados não por um, mas por dois especialistas em antropologia.

\subsection{Vivendo entre os Kayapó da Terra Indígena Capoto Jarinã}

A Terra Indígena Capoto Jarinã é um território multiétnico e multilinguístico. Inicialmente, o grupo Tapayúna que saiu da região do Wawi e buscou refúgio na TI Capoto Jarinã fundou residência e estabeleceu relações sociais com os Mebengôkrê da aldeia do Metyktire. Essa antiga aldeia, chamada atualmente de Metyktire Velho, está hoje abandonada e só é visitada pelos Tapayúna e pelos próprios Mebengôkrê para se conseguir palhas e jenipapo ${ }^{46}$. Com o abandono do Metyktire Velho, a maioria dos

\footnotetext{
${ }^{46}$ Várias etnias da região usam o jenipapo para produzir uma tinta inicialmente transparente, mas que se enegrece gradualmente no contato com a luz do sol. Essa pintura é essencial como adorno corporal
} 
Mebengôkrê mudou-se para uma nova aldeia, conhecida como Metyktire Novo ou apenas Metyktire.

Os Tapayúna viveram nessas duas aldeias, na beira do rio Xingu, e ajudaram efetivamente os Mebengôkrê a construir o Metyktire Novo. Nesse contexto, vários homens e mulheres tapayúna se casaram com pessoas originárias da aldeia do Metyktire. Um dos meus principais interlocutores na aldeia Kawerêtxikô, Orengô Tapayúna, casou-se com uma mulher mebengôkrê e possui cinco filhos com ela, todos residentes em Kawerêtxikô. Seus filhos foram alfabetizados, inicialmente, na língua Mebengôkrê e agora que a maioria frequenta a Escola Goronã na aldeia própria dos Tapayúna, eles estão aprendendo a falar e escrever em Kaykwakhratxi, como descreverei no capítulo 3 .

Essa formação na língua tapayúna só foi possível com assessoria da Funai, principalmente na figura da funcionária já aposentada Maria Eliza Leite. Ela organizou um curso de formação de professores indígenas, no qual também foram produzidas cartilhas para a alfabetização em Kaykwakhratxi para os Tapayúna. Como dito na introdução, cada grupo de professores trabalhava no seu próprio material de ensino, assessorado por linguistas e antropólogos. Todos os filhos de Orengô Tapayúna foram registrados em cartórios de cidades próximas e possuem dois sobrenomes: Tapayúna e Mebengôkrê.

Conheço, por outro lado, homens deste último grupo que casaram-se com mulheres tapayúna e, como Orengô, também tem ensinado duas línguas a seus filhos: o Mebengôkrê e o Kaykwakhratxi. É o caso de Kokokuntxi, homem mebengôkre casado com uma mulher tapayúna. O casal residia na casa do pai da esposa, Winkã Tapayúna, em Kawerêtxikô. Kokokuntxi me disse, certa vez, que pretende que seus filhos também aprendam o Português.

A esse conjunto de línguas da aldeia Kawerêtxikô e da região soma-se, ainda, o Panará. Esse último grupo era inimigo tradicional dos Mebengôkrê, imperando entre eles um constante clima de guerra. Os agrupamentos mebengôkrê foram os primeiros

de homens e mulheres, principalmente nos diversos períodos de festas. O jenipapo já foi plantado na aldeia Kawerêtxikô, mas suas mudas ainda estão muito novas para produzir os frutos de qualidade que a pintura corporal exige. A palha, por sua vez, é largamente usada na cobertura do teto das casas. Quando não vão ao Metyktire, os Tapayúna procuram por ela na floresta nas imediações de Kawerêtxikô: as folhas de uma palmeira da região são usadas como cobertura das residências. Contudo, a ida ao Metyktire, apesar de mais distante, pode ser proveitosa pois lá há palha concentrada em grande número nas diversas construções abandonadas. Assim, alguns homens, ainda hoje, fazem incursões regulares ao chamado Metyktire Velho para conseguir mais facilmente esses produtos. 
da região a ter contatos regulares com os não-indígenas, na figura dos irmãos VillasBôas. Dessa forma, os então chamados Kayapó tiveram um acesso anterior e privilegiado às cobiçadas armas de fogo dos não-indígenas, entre outros produtos. $\mathrm{Na}$ década de 1960, aproveitando-se dessa situação, guerreavam contra os Panará que, naquele período, só usavam bordunas e arcos-e-flecha. Os Mebengkôkrê possuíam, com isso, uma enorme superioridade bélica nas refregas, que só foi amenizada quando os próprios Panará também conseguiram acesso às armas de fogo, já em uma época em que os irmãos Villas-Bôas trabalhavam para submeter à pax os diversos grupos do PIX (ISA, op. cit. :43 e :183). Ainda hoje, as relações gerais entre esses dois grupos é, de alguma forma, marcada pela tensão guerreira desse período. ${ }^{47}$

Hoje, encontramos somente um homem panará vivendo em Kawerêtxikô. Waty-ia Panará é um senhor de cerca de 70-75 anos, casado com uma mulher tapayúna de aproximadamente a mesma idade. Com a morte, em 2014, do ancião Kakhrytxi Tapayúna, único homem tapayúna que ainda usava bodoque nos lábios e conservava oficialmente duas esposas, o panará Waty-ia e o tapayúna Wòtkatxi tornaram-se os dois homens mais velhos da aldeia. Waty-ia é reconhecido como exímio pescador e solicitado constantemente para dividir as caças grandes conseguidas por homens mais jovens, como uma anta ou porcos do mato. O apelo frequente a Waty-ia também se explica pela crença generalizada entre os caçadores de Kawerêtxikô que nenhum deles deve limpar e dividir a própria caça que matou. Uma atitude dessas interferiria negativamente nas suas habilidades como caçador. Assim, a caça é sempre divida por alguém que não a abateu, sendo distribuída por critérios que fogem ao simples desejo ou às relações de parentesco mais diretas do caçador.

Waty-ia fala o Mebengôkrê nas conversas cotidianas em Kawerêtxikô e, além disso, entende a língua Kaykwakhratxi, mas não consegue falá-la muito bem. Ela só usa o Panará quando conversa com algum parente distante, pelo rádio amador, ou quando recebe visitas de outros Panará. Ele também entende razoavelmente bem o Português falado, mas não sabe escrever, nem falar fluentemente essa língua.

\footnotetext{
${ }^{47}$ Existe uma produção cinematográfica sobre a desigual guerra dos Mebengôkrê contra os Panará: The tribe that hides from man (1970). O filme, dirigido por Andrew Cowell, é uma espécie de encenação/documentário da história de contato dos Panará com os não-indígenas. Atualmente, o antropólogo Fabiano Bechelany, também colega do Programa de Pós-Graduação em Antropologia Social da Universidade de Brasília, está analisando o uso, práticas e noções dos Panará referente às armas de fogo, em tese de doutorado que deverá ser defendida ainda este ano ou no início do próximo.
} 
Desse modo, essas são as cinco línguas faladas na região da Terra Indígena Capoto Jarinã e com as quais tive contato: o Português, o Mebengôkrê, o Kaykwakhratxi, o Kinsedje e também o Panará, esta última conhecida, ainda, como Krenakore $^{48}$. A ordem em que apresento essas línguas não é aleatória. Ela denota mais uma face da hierarquia vigente na região e, em menor grau, também na aldeia Kawerêtxikô.

Como mostrarei mais detalhadamente na minha análise do posto-de-saúde de Kawerêtxikô no capítulo 4, as conversas entre indígenas de diferentes etnias e aldeias pelo rádio amador que funciona no posto, ocorrem quase sempre em Mebengôkrê ou, menos frequentemente, também em Português. Tive ainda a oportunidade de presenciar vários encontros entre Tapayúna e Mebengôkrê, e Tapayúna e Panará dentro da Terra Indígena Capoto Jarinã. Em todas as ocasiões em que houve um diálogo verbal ${ }^{49}$, a conversa se deu em Mebengôkrê. Já presenciei, do mesmo modo, um tapayúna e um homem mebengôkrê se encontrando na cidade de Colider, entre outros encontros em diversas cidades do norte do Mato Grosso, como Peixoto de Azevedo ou o povoamento não-indígena de Guarantã, no município de Peixoto de Azevedo. Nessas ocasiões, fora da Terra Indígena Capoto Jarinã, o diálogo também se deu em Mebengôkrê. Assim, não há como negar o caráter de língua franca do Mebengôkrê nas relações internas entre os indígenas da Terra Indígena Capoto Jarinã e da região adjacente.

É preciso ressaltar, do mesmo modo, a importância do Português na Terra Indígena Capoto Jarinã. Entre os Mebengôkrê, fica mais claro o papel mediador dessa língua no contato com os não-indígenas. As lideranças tradicionais kayapó, como o cacique Raoni, da aldeia do Metyktire, ou o cacique Bedjâi, da aldeia Piaraçu, falam

\footnotetext{
${ }^{48}$ Fabiano Bechelany esclareceu que essa última denominação é como os Mebengôkrê e não-indígenas do período dos primeiros contatos chamavam os Panará. A autodenominação, que quer dizer simplesmente "gente" na língua nativa e pela qual a etnia é hoje conhecida, é "Panará".

${ }^{49}$ Há encontros entre, por exemplo, homens do Metyktire e homens de Kawerêtxikô sem que haja, necessariamente, uma conversa verbalizada. Por exemplo, nos campeonatos de futebol organizados pela prefeitura da cidade de São José do Xingu, várias etnias se encontram com times de futebol nãoindígenas sem que ocorra necessariamente um diálogo verbal. Os Tapayúna de Kawerêtxikô ganharam, inclusive, o campeonato de futebol dessa cidade no ano de 2014. Na final, jogaram contra um time de não-indígenas. Somente alguns indígenas, entre os dois lados, dominavam a língua do outro. Não é raro, do mesmo modo, que os times feminino e masculino, infantil e adulto, de Kawerêtxikô e do Metyktire Novo façam jogos amistosos entre si, isto sem que os jogadores necessariamente conversem. A combinação é feita pelos técnicos dos times. Lembro aqui que há um estudo da antropóloga Bruna Franchetto sobre o Alto Xingu do PIX, no qual a autora mostra que a comunicação entre as etnias da região se dá mais por um acervo ritualístico comum, do que propriamente pelo compartilhamento de uma língua franca (Franchetto, 2011).
} 
mal o Português. Contudo, em suas viagens às cidades da região, ou mesmo para o exterior, no caso do cacique Raoni, eles sempre vão acompanhados de jovens mebengôkrê que são fluentes tanto no Português quanto no Mebengôkrê.

Tive a oportunidade de encontrar Raoni em uma loja de roupas da cidade de Colider. Nessa ocasião, eu comprava vestidos para as mulheres tapayúna, acompanhado pelo professor Orengô Tapayúna. Orengô, que fala fluentemente o Mebengôkrê, o Kaykwakhratxi e o Português, atuou como tradutor na conversa que tive com Raoni. Este último pediu alguns vestidos que eu havia comprado para ele próprio dar de presente para mulheres mebengôkrê. Dos 22 vestidos que comprei, doei dois para Raoni e o restante foi dado às mulheres de Kawerêtxikô. Depois da saída de Raoni, Orengô comentou jocosamente comigo: "é o imposto pra viver no Capoto Jarinã." Ele fazia referência, justamente, à relativa hegemonia dos Mebengôkrê nessa região.

O mesmo acontece com Roptyktxi, o cacique da aldeia Kawerêtxikô. Seu Português é precário e, quando ele vai a reuniões com funcionários públicos nãoindígenas ou participa de algum evento em que há falas em Português, sempre é assessorado por algum professor da Escola Goronã, normalmente Wengroi Tapayúna ou Orengô. Isso não acontece quando Roptyktxi conversa com outros indígenas da região, conversas que, como visto, são sempre em Mebengôkrê - quando essas pessoas não são, é claro, Tapayúna, ocasião em que as falas se dão somente em Kaykwakhratxi. Essa última língua é bastante próxima ao Kinsedje e, nos encontros de pessoas desses dois povos, também não se fala o Mebengôkrê.

Para os Tapayúna de Kawerêtxikô não há grandes problemas em reconhecer a relativa hegemonia dos Mebengôkrê na região. Várias lideranças, entre elas o próprio cacique Roptyktxi, são claras e diretas quando afirmam que, hoje, os Kaykwakhratxi não estão vivendo mais em suas terras originais, mas sim na região tradicional dos Mebengôkrê.

Nesse contexto, as relações internétnicas entre indígenas são muito diferentes das relações interétnicas mais gerais com os não-indígenas. A sociabilidade entre as diversas etnias indígenas que compõe a Terra Indígena Capoto Jarinã pode ser lida a partir da chave teórica desenvolvida por Alcida Rita Ramos na já citada obra Hierarquia e simbiose (1980). Nesse texto a autora aponta para a existência de diferenças importantes entre as relações entre indígenas, de uma lado, e as relações 
entre indígenas e não-indígenas, de outro. Assim, embora também existam relações assimétricas entre os povos indígenas, estas diferem profundamente das relações dos indígenas com os não-indígenas. Nos dias de hoje, as relações entre, por exemplo, os Tapayúna e os Kayapó, que Ramos chamaria de “intertribais" (idem), são relativamente assimétricas, como demonstrarei mais vezes no presente capítulo. Contudo, como também fica claro nos casos etnográficos apresentados na coletânea organizada por Ramos, essa assimetria não pode ser comparada às relações dos indígenas com os não-indígenas na medida em que elas não comportam: 1) uma dominação ou sujeição completa, nos moldes conhecidos das relações dos indígenas com os não-indígenas (os quais a autora se refere como "brancos"). Há, por exemplo, diversos espaços, físicos e sociais, em que essa assimetria geral não opera ou é até mesmo invertida nas relações internas entre os indígenas; 2) os grupos em interação, como também é colocado na obra citada, não baseiam suas relações sociais na crença que os relativamente inferiores precisam desaparecer e, assim, se fazerem totalmente 'fagocitados' ou civilizados pelos que se auto-denominam superiores; 3) há, nessas situações de contato entre povos indígenas, um respeito rigoroso pela ocupação tradicional de um território por grupos mais antigos. Esse respeito não impede, como é o caso dos Tapayúna entre os Mebengôkrê, que outros grupos venham a ocupar conjuntamente tal território. Porém, essa ocupação passa sempre pelo crivo do grupo indígena que é tido como habitante costumeiro da região, estabelecendo-se, na maioria dos casos, relações que, para citar a autora mais uma vez, poderíamos corretamente classificar como "simbióticas" (ibid idem).

Assim, como vários jovens homens adultos Mebengôkrê e Tapayúna me contaram, os Tapayúna só fundaram Kawêrêtxikô depois de receberem anuência explícita do cacique Raoni da aldeia Metyktire, a mais respeitada liderança política da região. Por essas razões, para caracterizar as relações interétnicas entre os povos indígenas da região, prefiro falar de uma "hegemonia relativa" que difere das relações que os indígenas estabeleceram historicamente com os não-indígenas. 


\subsection{A balsa da BR-080 e a relação com os Mebengôkrê}

A balsa que atravessa veículos e pessoas no local onde a antiga rodovia BR 080, hoje MT 322, corta o rio Xingu (Mapa 02), entre os municípios mato-grossenses de Peixoto de Azevedo e São José do Xingu, oferece uma oportunidade privilegiada para a análise das relações interétnicas no PIX. Poucos quilômetros rodovia acima, no sentido de quem vai de Peixoto para São José, há uma das maiores aldeias da região: Piaraçu, com cerca de 500 habitantes. Atualmente, os Mebengôkrê dessa aldeia controlam a balsa que atravessa o rio. Há balseiros mebengôkrê com anos de experiência na travessia, tanto no período da seca, quando há mais veículos atravessando, aproveitando as melhores condições da estrada de terra, quanto também no período das chuvas, ocasião em que a travessia fica mais difícil com o rio Xingu transbordado, o que demanda ainda mais perícia do balseiro. Na época das chuvas, contudo, o tráfico de veículos é sensivelmente menor devido às condições quaseintrafegáveis da rodovia. Nesse local, foi implementado um pedágio com cobradores mebengôkrê que recebem o dinheiro dos motoristas transeuntes (pessoas a pé não pagam) e entregam um comprovante impresso do pagamento, o que garante a livre passagem desses últimos num segundo posto de cobrança instalado na altura da aldeia Piaraçu, onde quase sempre há também um homem Mebengôkrê conferindo os recibos. 


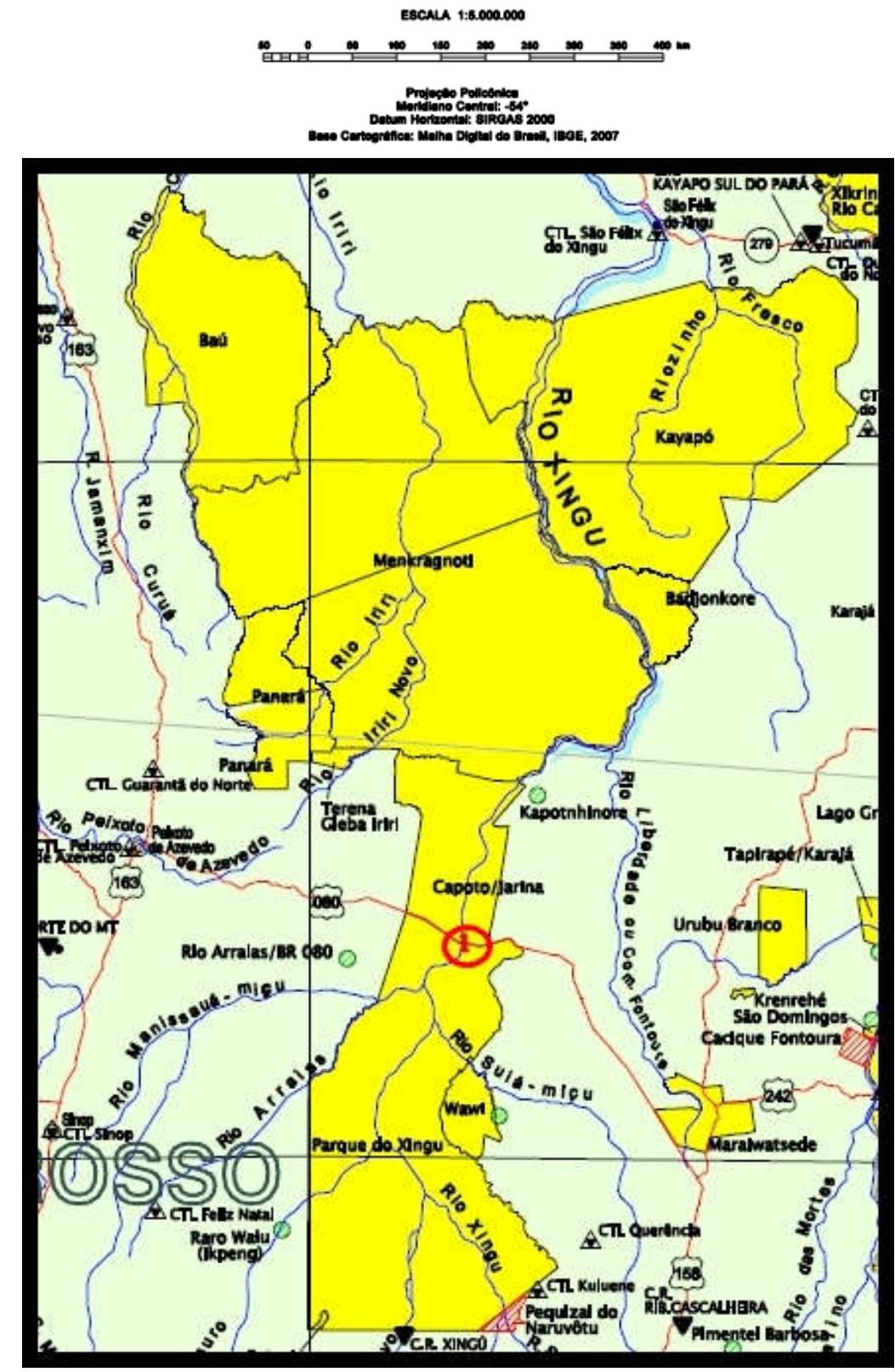

Mapa 02: O número 1 dentro do círculo vermelho informa a localização da balsa dentro da Terra Indígena Capoto Jarinã. A aldeia de Piaraçu fica a dois quilômetros da balsa. No mapa, a atual MT 322 ainda é referenciada como BR 080 (linha vermelha que cruza o círculo vermelho) [Fonte: Adaptado 
pelo autor diretamente do Mapa de Terras Indígenas da Funai. Disponível em funai.gov.br, com acesso em 15/09/15]

Idealmente, todos os não-indígenas que atravessam o rio Xingu por meio de algum veículo motorizado são cobrados na balsa. $\mathrm{O}$ valor da cobrança acompanha uma tabela gradual de preços, que vai desde motos, passando por carros de passeio, caminhonetes, pequenos caminhões, até veículos bi-trem, que são caminhões que arrastam duas carrocerias e, assim, pagam mais na travessia do que aqueles de carroceria simples. ${ }^{50}$ Os veículos, não importando a quantidade de passageiros, pagam somente a travessia do veículo.

No entanto, existe uma linha de ônibus que saí de Peixoto de Azevedo e corta o norte do Mato-Grosso, chegando até o sul do Pará. Compondo essa linha, há dois ônibus, um em cada sentido da rodovia, três vezes por semana, que precisam obrigatoriamente atravessar o rio Xingu pela balsa e, portanto, passar dentro da Terra Indígena Capoto Jarinã - faça chuva ou faça sol. A travessia do ônibus de linha pela balsa também é cobrada, mas de modo diferenciado: é cobrada a passagem do ônibus enquanto veículo e também a travessia dos passageiros individualmente. Por motivos de segurança, os passageiros precisam descer do ônibus quando este sobe na balsa para efetuar a travessia do Xingu. Neste momento, o cobrador mebengôkrê recolhe a tarifa individualizada de cada um dos passageiros. Enquanto isso, um dos dois motoristas que se revezam dirigindo o ônibus pagam a travessia do veículo aos operadores indígenas da balsa. Por vezes, a cobrança dos passageiros só é feita quando o ônibus chega no posto-de-cobrança da aldeia Piaraçu. Nesse caso, um homem mebengôkrê sobe no ônibus e recolhe a contribuição de cada um dos nãoindígenas. Só depois disso o ônibus é autorizado a seguir viagem.

Os indígenas da região usam sistematicamente essa linha de ônibus. Contudo, nenhum deles paga qualquer tarifa para a travessia na balsa do Xingu. Na verdade, boa parte deles não paga nem mesmo a tarifa cobrada pela operadora da linha de ônibus. Assim, geralmente, os passageiros indígenas viajam de graça para as cidades das redondezas. Isso acontece da seguinte maneira: os passageiros indígenas embarcam no posto-de-cobrança em Piaraçu. Depois de alguns quilômetros, quando o

\footnotetext{
${ }^{50}$ Optei deliberadamente por não divulgar os preços cobrados na balsa. Esse posicionamento se justifica na medida em que essas informações poderiam ser potencialmente usadas por não-indígenas para criticar, de forma negativa e superficial, a maneira como a renda da balsa é utilizada pelos grupos indígenas da região.
} 
cobrador mebengôkrê vai recolher a tarifa individual dos passageiros, os indígenas pedem que suas passagens sejam pagas com a verba já recolhida pela balsa. $\mathrm{O}$ cobrador, então, paga em espécie as referidas passagens a um dos dois motoristas; este, por sua vez, entrega o bilhete pago para os passageiros indígenas que continuam normalmente a viagem.

Eu próprio usei esse sistema para chegar à aldeia Kawerêtxikô e, é claro, para dela sair e passar alguns dias em determinada cidade da região para fazer compras, fazer backup das notas de campo na Internet e dar notícias aos familiares, amigos e orientador sobre o andamento da minha pesquisa. Após um mês ou pouco mais vivendo na aldeia Kawerêtxikô, eu passava uma semana em alguma cidade da região, normalmente em Peixoto de Azevedo, levando a cabo esses afazeres.

Nessas viagens, nunca aceitei que a minha passagem de ônibus fosse paga com o dinheiro recolhido da balsa, ainda que em certa ocasião, quando fui acompanhado pelo professor Orengô Tapayúna, ele tenha insistido com o cobrador mebengôkrê para que assim fosse feito, pois íamos para a cidade para resolver problemas referentes à Escola Goronã de Kawerêtxikô e não para tratar de minhas questões particulares. Mesmo assim, paguei a minha passagem com recursos próprios.

Durante as minhas primeiras viagens para a cidade, eu também pagava normalmente a tarifa individual da balsa, exigida dos passageiros não-indígenas do ônibus de linha para a travessia do rio. Contudo, quanto mais usava o ônibus, mais era conhecido pelos cobradores e barqueiros de Piaraçu, além dos passageiros indígenas. $\mathrm{Eu}$ voltava para a cidade quase sempre pintado de jenipapo e levando comigo algum presente que havia ganhado na aldeia Kawerêtxikô, como bordunas, flechas, arcos ou esteiras, o que fazia com que eu não fosse imediatamente confundido com outros passageiros não-indígenas. Depois de algumas idas e vindas, todos cobradores mebengôkrê me conheciam e se recusavam a cobrar-me a tarifa da travessia da balsa.

Pude notar que essa isenção de tarifa também era aplicada aos técnicos de saúde indígena, médicos, dentistas e farmacêuticos que trabalhavam nas aldeias da região e que, por vezes, usavam esse transporte. Quando o cobrador de Piaraçu se aproximava, ainda que este último não reconhecesse o funcionário, ele era recebido com um caloroso "mei ku mré", que é o cumprimento tradicional no encontro entre os Mebengôkrê. O cobrador, então, perguntava se o não-indígena era funcionário da saúde na região e, quando este confirmava a informação, era liberado do pagamento 
da tarifa individual da balsa. De todo modo, como eu próprio, esses funcionários sempre pagavam a tarifa geral da operadora da linha de ônibus ${ }^{51}$.

Os veículos que fazem a travessia para entregar cotas de combustível para as aldeias da região também eram isentos do pagamento de qualquer tarifa na balsa. Esclareço aqui que as escolas e os postos-de-saúde possuem um quinhão em gasolina e óleo lubrificante para motores dois tempos, que podem usar, por exemplo, na transferência por barco de pessoas gravemente doentes, no caso da saúde, ou, no caso da educação, para fazer o transporte de professores para algum curso especial organizado pela Secretaria de Educação do Mato Grosso. Assim, os veículos que transportam tais combustíveis para as aldeias da região do Capoto Jarinã também estão isentos do pagamento de qualquer tributo na balsa.

Não é preciso dizer que a cobrança da tarifa individual de outros nãoindígenas indignava sobremaneira boa parte destes passageiros que, além de pagar o translado para a operadora da linha de ônibus, também deviam, no meio da viagem, despender mais dinheiro para a travessia da balsa. A reputação dos indígenas entre os não-indígenas da região não é nada positiva e a cobrança, iniciada no ano de 2013, tem contribuído para dar força aos estereótipos mais desfavoráveis sobre os índios em geral, mais particularmente aqueles referentes à ociosidade tida por muitos nãoindígenas como característica dos habitantes do PIX - e, também, dos índios em geral. Os principais alvos desses estereótipos eram os índios que passaram a morar definitivamente na cidade ou que passam nela um grande período de tempo.

De todo modo, a balsa, tanto no período da seca quanto no período da chuva, gera uma considerável renda em dinheiro para, virtualmente, todos os indígenas da região. Para entender melhor como tal renda é divida entre as diversas etnias, é preciso conhecer um pouco da história da retomada da Terra Indígena Capoto Jarinã, da fundação da aldeia Piaraçu e do processo que levou à tomada da balsa do governo estadual do Mato Grosso pelos indígenas.

Já informei que a Terra Indígena Capoto Jarinã foi retirada da área do PIX para a construção de um trecho da BR 080, ainda durante o auge do último período

\footnotetext{
${ }^{51}$ Os funcionários da educação que cotidianamente trabalham nas escolas da região, como professores ou diretores, são, em sua maioria quase absoluta, indígenas. Por vezes alguns funcionários nãoindígenas da educação fazem visitas às aldeias, no intuito de dar algum curso especial. Contudo, nessas ocasiões, eles fazem as viagens em carros oficiais da Secretaria de Educação e não de ônibus, o que lhes isentava do pagamento da tarifa individual e da tarifa sobre o veículo. Os carros oficiais da saúde também não pagam.
} 
ditatorial brasileiro, nas décadas de 1960/70. Pode-se notar que a rodovia nunca foi completamente terminada: boa parte dela ainda é uma perigosa estrada de terra que não possui qualquer sinalização e nem manutenção regular. Todas as pontes sobre os igarapés e riachos são construídas com troncos de madeiras improvisados. Por vezes, os fazendeiros do entorno do PIX alugam um trator-patrola para melhorar as condições da rota de escoamento de seus produtos; outras vezes, esse serviço é feito por alguma prefeitura dos municípios da região; na maior parte do tempo, a rodovia jaz em condição quase-intransitável, principalmente durante o período de cheia do rio Xingu e, portanto, de chuvas na região. É comum o ônibus de linha atolar, assim como outros veículos, mesmo aqueles com tração $4 \times 4$. Eu já passei algumas boas horas esperando socorro quando viajava tanto no ônibus de linha regular da região, como em caminhonetes traçadas de alguma instituição estatal nas quais pegava carona. ${ }^{52}$

Já foi dito que os Mebengôkrê da região retomaram suas terras originais ainda na primeira metade da década de 1980 , no período do regime militar brasileiro conhecido como redemocratização. Além da ocupação desse território por diversas aldeias, o cerne da conquista foi a tomada de controle da balsa do governo estadual do Mato Grosso e a criação da referida cobrança de pedágio. Com esse processo, os indígenas passaram a controlar efetivamente quem passa pela Terra Indígena Capoto Jarinã e a cobrar em dinheiro os não-indígenas pela travessia do rio Xingu. A partir dos relatos da funcionária aposentada da Funai Maria Eliza Leite e da fala, traduzida por essa última, de lideranças mebengôkrê, principalmente de Megaron, sobrinho de Raoni, é possível fazer uma breve reconstituição dessa retomada.

Antes da retomada, o atual local da aldeia Piaraçu era considerado um "Bangue". O termo vem da expressão do Velho Oeste estadunidense, "bang-bang", e é utilizado para designar um local de encontro de não-indígenas, mormente de trabalhadores do campo, onde impera o consumo indiscriminado de fortes bebidas alcoólicas, a prostituição aberta e a violência imposta por armas de fogo. O Bangue era, assim, um espaço de confraternização dos não-indígenas com mortes, brigas e desavenças em geral. Essa alcunha ainda é hoje utilizada por indígenas da região para

\footnotetext{
52 Pegar carona no carro da Funai, da Secretaria de Educação, do Instituto Raoni, do Distrito Sanitário Especial Indígena Kayapó (DSEI Kayapó) ou de outro órgão, público ou não, que esteja fazendo algum trabalho na região, é uma outra maneira que indígenas e não-indígenas usam frequentemente para viajar de graça.
} 
se referir à pequena cidade de São José do Xingu. Em 1979, numa festa de peões, um grupo de guerreiros de diversas etnias, depois de vários avisos para que os nãoindígenas se afastassem da área, invadiram o antigo Bangue, que se localizava onde hoje é a aldeia Piaraçu, e mataram 11 pessoas. Vários não-indígenas conseguiram escapar da emboscada, atribuída aos Mebengôkrê, e ajudaram a compor o estereótipo dessa etnia no imaginário não-indígena regional como perigosos guerreiros - além de preguiçosos, por mais incrível que possa parecer. Entre outras refregas, os nãoindígenas foram empurrados para fora dos atuais limites do PIX, onde hoje está a sede do município de São José do Xingu, o Bangue moderno.

Maria Eliza Leite me contou que participou pessoalmente da retomada da balsa do rio Xingu em 1984. Nessa ocasião, não só os Mebengôkrê, mas também os Panará, os Tapayúna, os Yudjá (Juruna), entre outras etnias, envolveram-se ativamente na captura e controle da balsa. A pressão indígena se deu a partir da seguinte estratégia: o 'sequestro' de funcionários públicos estaduais/federais e o 'encarceramento' deles em Piaraçu. Os índios negociavam então a soltura dos 'seqüestrados' a partir das pautas políticas das diversas etnias. A principal reivindicação era, é claro, o controle da entrada e saída de não-indígenas na região.

Uso os termos 'encarceramento' e 'sequestro' com aspas simples pois diversos funcionários da Funai, entre eles Maria Eliza Leite, se voluntariaram para ser 'sequestrados' nessa ocasião. Havia, assim, dois grupos de 'cativos': um que realmente estava sendo mantido contra seu alvitre em Piaraçu e um outro grupo, simpático à causa indígena, que permanecia 'sequestrado' por vontade própria. A polícia e a imprensa que cobria o evento não sabiam dessa divisão e os cativossimpáticos tinham que encenar estar presos quando algum fotógrafo ou repórter da imprensa era aceito em Piaraçu para noticiar o tratamento dispensado aos 'sequestrados'. No restante do tempo, permaneciam livres para ir e vir em Piaraçu.

Atualmente, o Governo Federal quer o asfaltamento completo da rodovia e a construção de uma ponte sobre o rio Xingu. As obras acabariam com a balsa e o pagamento pela travessia. Em 2014, Raoni Metyktire e seu sobrinho, Megaron Txucahamãe, as duas maiores lideranças mebengôkrê da região, depois de anos sendo pressionados para aceitar os projetos de modernização da rodovia, cederam parcialmente. Aceitaram o asfaltamento, mas não a construção da ponte. No início de 
2015, quando voltei dos meus últimos dias do período de campo, empreiteiras já trabalhavam na região para o asfaltamento completo da rodovia.

Ao lado da aldeia Piaraçu existe, hoje, uma aldeia Yudjá, auto-denominação dos Juruna, com cerca de 1/3 dos habitantes da aldeia Mebengôkrê. Pude conversar com algumas lideranças yudjá e elas foram enfáticas em afirmar que se mudariam, caso realmente ocorra o asfaltamento da rodovia, temendo um contato mais íntimo com os não-indígenas com a melhoria das condições de tráfego na BR-080 (MT 322). Outros grupos, como os próprios Mebengôkrê, já pensam diferentemente e acham que o asfaltamento e até mesmo a construção da ponte podem ser positivos. Poder-se-ia, assim, vender mais facilmente o artesanato indígena, seria menos penoso viajar para as cidades da região em tratamento de saúde ou por outros motivos e, no caso da construção da ponte, poder-se-ia substituir a balsa por uma cobrança de pedágio, o que diminuiria o efetivo de pessoas envolvidas na cobrança do pedágio e agilizaria o processo.

De todo modo, é interessante matizar aqui o protagonismo dos Mebengôkrê. Ele está intimamente relacionado ao fato desses últimos se considerarem e, ao mesmo tempo, também serem considerados pelas outras etnias migrantes ao PIX e pelos nãoindígenas, como os ocupantes tradicionais da região Capoto Jarinã. Ainda que, como visto, a balsa tenha sido retomada por uma junção de forças de diferentes etnias, ela está localizada na área tradicional dos Mebengôkrê, ao lado de Piaraçu, uma aldeia que era antigamente um povoado não-indígena e que foi conquistado pela guerra direta contra esses últimos, finalmente expulsos para fora dos limites do PIX.

Pela experiência que tive entre os Tapayúna e também pelos comentários de pessoas, na sua maioria jovens homens de outros povos indígenas que falavam Português, percebi que a hegemonia Mebengôkrê está menos relacionada a uma constante pressão dos últimos por um status diferenciado e mais ao respeito geral daqueles que, não tendo mais como manterem-se em suas respectivas terras tradicionais, foram obrigados a migrar para a Terra Indígena Capoto Jarinã para não desaparecer por completo. É exatamente esse o ponto central que caracteriza a relação dos Tapayúna com os Mebengôkrê: os Tapayuna foram retirados à força de sua morada cosmológica, geográfica e simbólica, para habitar, a contra-gosto, uma região na qual os Mebengôkrê já estabeleciam relações profundas com os marcos 
geográficos, relações semelhantes às que os Tapayuna, agora desterrados, possuíam com seu território de origem.

Porém, os Tapayúna, ao contrário dos não-indígenas, não tentam usurpar essa relação primordial dos Mebengôkrê com suas terras tradicionais. Como alienados de seu próprio território, eles se submetem, em certos assuntos e situações específicas, à hegemonia Mebengôkrê. Assim, para se mudar do Metyktire e fundar a aldeia de Kawerêtxikô, eles esperaram o aval dos Mebengôkrê. Como visto, eles só iniciaram a mudança e a construção da nova aldeia após o consentimento do cacique Raoni, que é uma figura bastante respeitada entre os Tapayúna, que conviveram ativamente com ele nas duas aldeias do Metyktire, aldeia da qual Raoni é o cacique principal.

É preciso acrescentar ainda que, em termos sociológicos, a distância relativa entre esses dois grupos é bastante menor que a distância que os diferencia em relação aos não-indígenas. Essas duas etnias, assim como os outros grupos do PIX, têm consciência desse fato e o episódio da retomada da balsa ilustra bem esse jogo de distâncias relativas. Assim, para os Tapayúna, é melhor ter a balsa controlada por um outro grupo indígena, ainda que o grupo hegemônico na região, do que deixá-la nas mãos dos não-indígenas. A maneira como os Mebengôkrê controlam a balsa também confirma o acerto dessa escolha política. Como visto, há uma série de vantagens para os indígenas em geral da região no uso cotidiano da balsa. Eles podem, entre outros proveitos, fazer viagens gratuitas nos ônibus de linha, pagos diretamente pelo dinheiro angariado na balsa.

O fato da balsa ser administrada pelos Mebengôkrê e não pelos não-indígenas também traz outros benefícios. Para apreendê-los, é necessário adentrar o campo bem mais complexo e nebuloso das relações internas entre as diversas aldeias da Terra Indígena Capoto Jarinã. De antemão, adianto que tais relações são marcadas, quando vistas a partir do olhar não-indígena, pelo alto índice de independência relativa de cada uma das aldeias. Não há qualquer tentativa de se formar uma espécie de 'confederação' entre os diversos grupos que coabitam na Terra Indígena Capoto Jarinã. Cada localidade conserva-se independente nas escolhas de seus caciques e lideranças. Não existe, assim, nenhuma força geral centralizadora que poderia determinar o resultado dessas e de outras escolhas, nem mesmo o forte respeito que todos têm pela figura do cacique Raoni. 
O modo de produção dos bens de consumo é também relativamente autônomo, embora o sustento, oriundo da coleta, da roça, da caça e da pesca, admita, sem dúvida, trocas entre aldeias. Existem salários e outras vantagens pagas em dinheiro que convertem-se em bens que a aldeia não produz diretamente, como açúcar ou sal de cozinha, mas aqueles que adquirem esses bens acabam trocando-os, em grande medida, por produtos típicos da aldeia, como farinha de mandioca ou massa de beiju. De modo geral, a regra da produção em Kawerêtxikô é produzir mais do que o necessário para a subsistência e a troca não é feita somente para adquirir o básico para o sustento diário, mas também aquilo que tal ou qual localidade parece ter de mais exímio e bem feito, como a cerâmica dos Yudjá, os cestos dos Kinsedje ou as armas de fogo dos não-indígenas. Nesse sentido, os Tapayúna são conhecidos como exímios produtores de esteiras que são muito cobiçadas pelos outros grupos. Do ponto de vista político, as aldeias também são independentes. Quando há desavenças internas mais graves entre os membros de uma aldeia, dependendo do grau que as mesmas tomam, o mais sério que pode acontecer é uma divisão da aldeia, como ocorreu no caso já citado dos Tapayúna na Terra Indígena Wawi.

Se parece claro que os Mebengôkrê ocupam uma posição privilegiada na Terra Indígena Capoto Jarinã, os dados que possuo sobre as relações dos outros grupos indígenas da região com os Mebengôkré são modestos. Eles se baseiam em conversas esparsas que mantive com alguns homens que encontrei aleatoriamente nos períodos de estadia nas cidades da região, ou ainda em conversas informais com o antropólogo Fabiano Bechelany, que fazia pesquisa entre os Panará no mesmo período. Já os meus dados sobre os Tapayúna são mais confiáveis. Eles foram coletados ao longo de vários meses de estada na aldeia Kawerêtxikô, o que me possibilitou fazer diversas viagens com estes últimos passando pela balsa. Além disso, pude acompanhar os debates acalorados que aconteciam na Casa dos Homens da aldeia Kawerêtxikô, muitos dos quais tinham a balsa como tema central. Esses debates se davam ou em Kaykwakhratxi ou em Mebengôkrê. Embora não tenha domínio de nenhuma das duas línguas, pude perceber que ambas não possuem termos próprios para expressões como "balsa", "balseiro", "pedágio" e usam, obrigatoriamente, os vocábulos em Português no meio do discurso em língua nativa quando estão tratando desse tema. Isso me possibilitava, pelo menos, identificar o momento em que os homens de Kawerêtxikô debatiam esses assuntos nas noites quentes e escuras na Casa dos Homens. 
Orengô Tapayúna e Kokokuntxi Metyktire, homem mebengôkrê casado com uma mulher tapayúna, participavam ativamente das discussões na Casa dos Homens. Ambos possuem um bom conhecimento do Português, já que passaram grandes temporadas de suas vidas na cidade. ${ }^{53}$ Após construir uma gradual amizade e ter maior intimidade com eles, eles se tornaram interlocutores privilegiados e pude entender melhor o conteúdo das conversas que eram realizadas na Casa dos Homens. Quando um deles estava menos ocupado no debate, eu pedia que me contasse o que estava então sendo dito. No entanto, nessas ocasiões, era geralmente impossível interpelá-los imediatamente para obter uma tradução dos diálogos e, assim, eu aguardava momentos mais oportunos, depois da reunião ou na manhã do outro dia, para obter as informações que desejava.

Assim, essa outra vantagem que as diversas etnias possuem, entre elas os Tapayúna, no atual modo de gerência da balsa, é a possibilidade de fazer retiradas em dinheiro mais ou menos regulares frente à administração mebengôkrê. Passo a analisar então os debates que acompanhei na Casa dos Homens de Kawerêtxikô sobre esse tema. Eles nos darão alguma noção de como é repartida a renda da balsa e, assim, de que maneira os Tapayúna têm acesso a parte do dinheiro que é coletado.

\subsection{As discussões sobre o dinheiro da balsa em Kawerêtxikô}

Para finalizar este capítulo, quero trazer alguns exemplos dos debates mais formais sobre a balsa que ocorriam normalmente, mas não exclusivamente, na Casa dos Homens, assim como as conversas menos formais que tive com diversos Tapayúna, falantes do Português, sobre a mesma temática. Essas falas diziam respeito à repartição da renda da balsa e também revelam aspectos interessantes das relações interétnicas na Terra Indígena Capoto Jarinã.

\footnotetext{
${ }^{53}$ Kokokuntxi trabalhou durante alguns anos em uma clínica particular e no hospital público da cidade de Peixoto de Azevedo, tendo iniciado, porém não concluído, um curso técnico em enfermagem; Orengô estudou durante anos na escola pública de São José do Xingu e finalizou o ensino médio com o curso de magistério indígena na escola de Piaraçu, sendo, atualmente, professor da Escola Goronã de Kawerêtxikô. O conhecimento de Kaykwakhratxi de Orengô e o de Mebengôkrê de Kokokuntxi é inquestionável, já que ambos possuem esses respectivos idiomas como primeira língua
} 
A aldeia Kawerêtxikô fica a cerca de duas ou três horas de barco rio-abaixo da balsa do rio Xingu. O tempo de viagem depende da potência do motor de popa usado nos pequenos barcos de alumínio típicos da região, chamados "voadeiras". Esse nome foi dado a essas embarcações em razão da posição que elas apresentam, em velocidades acentuadas, quando boa parte da proa fica fora d'água e a popa afunda sensivelmente, dando a impressão, principalmente para os que vêem de fora, que o barco pegará vôo. ${ }^{54}$ Nas imediações de Kawerêtxikô, a cerca de cinco minutos de barco, existem duas pequenas comunidades com aproximadamente vinte pessoas cada: Bytire e Kromari. Essas duas localidades são exclusivamente Mebengôkrê. ${ }^{55}$ Elas dependem da aldeia tapayúna tanto para o atendimento de saúde, pois em nenhuma das duas há técnicos de saúde, como descreverei no capítulo 4, quanto para a educação escolar, já que nenhuma delas possui escolas, como tratarei mais pontualmente no capítulo 3. Em todos os outros aspectos, como a produção de roças, a caça e a pesca, essas duas comunidades são independentes de Kawerêtxikô.

$\mathrm{Na}$ aldeia Kawerêtxikô, em fevereiro de 2014, Orengô me disse, em conversa em sua casa, que Nokêrê, uma reconhecida liderança tapayúna de cerca de 40 anos, ia pegar dinheiro na balsa para comprar mercadorias no Bangue: sal, açúcar, café, feijão, arroz, macarrão, óleo de cozinha, sabão em barra, entre outros produtos. Até então, eu nunca havia ouvido falar da possibilidade de algum Tapayúna retirar dinheiro diretamente na balsa. Sabia apenas das viagens gratuitas para indígenas no ônibus regular. De todo modo, Nokêrê passou um rádio do posto-de-saúde combinando com o pessoal de Piaraçu o dia em que iria para essa aldeia. Segundo Orengô, podia acontecer de Nokêrê chegar em Piaraçu e ainda não haver dinheiro suficiente arrecadado naquele dia. Nesse caso, Nokêrê dormiria em Piaraçu, esperando o provento da balsa do dia seguinte. Quando tivesse feito as compras, voltaria com as mercadorias passando antes um rádio de Piaraçu para Kawerêtixkô para que algum

\footnotetext{
${ }^{54}$ Indígenas e não-indígenas já narraram-me situações em que barcos com pouco peso e com motor de popa potente, acima dos $40 \mathrm{hp}$, realmente podem passar algum tempo no ar, voltando violentamente a bater na água caso o piloto os acelerem muito bruscamente. Todos os pilotos com os quais tive contato eram indígenas e eles precisavam ter experiência para saber dividir bem o peso na distribuição das pessoas e das bagagens no barco. Normalmente coloca-se duas pessoas sentadas na parte da frente para aumentar o peso na proa e diminuir o risco da embarcação decolar. Existem, também, barcos feitos localmente de madeira, mas esses são usados para a pesca em locais próximos à aldeia, ao menos em Kawerêtxikô.

${ }^{55}$ Pelo que pude averiguar, há somente um homem tapayúna casado com uma mulher mebengôkrê que reside no Kromari.
} 
barqueiro, provavelmente Pinkã Tapayúna, fosse buscá-lo. Segundo Orengô, o pessoal de Kawerêtxikô vai à balsa pegar dinheiro mais ou menos uma vez por mês.

Mais tarde, descobriria que outras aldeias da região, como o Metyktire ou o Kempó, comunidades dos Mebengôkrê, também possuem uma espécie de cota na balsa. Um homem mebengôkrê, falante de Português, me explicou genericamente que essa divisão é feita com base na quantidade de habitantes de cada aldeia. O Metyktire, por exemplo, tem mais do dobro da população de Kawerêtxikô e, assim, recebe mais dinheiro da balsa. Da mesma forma, a própria aldeia de Piaraçu tem sua cota de dinheiro, baseada também na quantidade de habitantes.

Em Kawerêtxikô pelo menos, as mercadorias trazidas com o dinheiro da balsa são para a comunidade, ou seja, elas não são destinadas a uma casa ou família extensa específica e devem ser distribuídas para toda a aldeia. Esta categoria de comunidade é usada por todos os falantes de Português que encontrei. A distribuição das mercadorias compradas com o dinheiro da balsa é feita pelo cacique Roptyktxi e leva em consideração o acesso diferenciado de cada família a tais bens. Assim, não se trata de uma distribuição igual entre as famílias. Na aldeia, existem pessoas específicas (e, portanto, também casas e famílias) que ganham salários da saúde ou da educação (ou outra fonte de renda, como o Bolsa Família ou aposentadorias rurais) e, com esses proventos, podem adquirir as mesmas mercadorias que são coletivamente compradas com o dinheiro da balsa. Essas pessoas não são totalmente excluídas do processo de distribuição das mercadorias compradas com a renda da balsa, mas sua cota de produtos é menor. As famílias que não possuem nenhum tipo de renda, isto é a maioria das famílias da aldeia, recebem uma cota maior de produtos.

Nesse sentido, é interessante notar que as casas que não recebem (ou recebem menos) dinheiro produzem mais produtos oriundos de suas atividades econômicas locais: mandioca, farinha, polvilho (beiju), milho, abóbora, abacaxi - produtos da roça em geral; pesca e caça; venda e troca de artesanato e utensílio como bordunas, arcose-flechas e esteiras; criação de galinhas. Essa produção é destinada ao sustento familiar e à troca.

Esse é o caso, por exemplo, da casa do cacique Roptyktxi ou do pajé Wotkàtxi. Nenhum dos dois possui qualquer renda fixa em dinheiro e precisam despender grande quantidade de tempo nas atividades citadas, sendo Wotkà, como é normalmente chamado, um dos artesãos mais prendados de Kawerêtxikô. Esse não é, 
por exemplo, o caso de Orengô, que recebe salário de coordenador pedagógico da Secretaria de Educação do Mato Grosso e o Bolsa Família do Governo Federal. Morei alguns meses na casa de Orengô e o vi saindo várias vezes para pescar, caçar ou trabalhar na roça. Ele e sua família possuem uma modesta plantação de milho nos fundos da casa, além de uma pequena roça de mandioca, mais adentro da floresta. A situação monetária de Orengô é mais vantajosa que a de outros indígenas nãoassalariados que precisam se dedicar mais substancialmente a essas atividades ${ }^{56}$.

Esta constatação não resulta do fato de eu ter sido hóspede na casa de Orengô, provendo da cidade boa parte da alimentação que consumíamos, eu, ele e sua família, durante a minha estada. ${ }^{57}$ Quando me mudei para o posto-de-saúde, continuei acompanhando o cotidiano dele e sua rotina permaneceu idêntica, mesmo se ele e sua família consumiam, então, mais produtos locais. A única conclusão à qual podemos chegar é que Orengô e sua família não consomem mais produtos da cidade por terem proventos em dinheiro, mas somente que ele e sua família, em razão de sua renda financeira, possuem um acesso privilegiado às mercadorias advindas da cidade, podendo trocá-las por bens que são largamente consumidos por absolutamente todos em Kawerêtxikô, como o beiju e a farinha de mandioca. Obviamente, Orengô, ao contrário de Roptyktxi ou Wotktà, gasta boa parte do seu tempo preparando e dando aula, ou ainda participando de reuniões tanto em Kawerêtxikô como também em Piaraçu ou em alguma cidade da região. Mesmo quando não é para participar de reuniões ou outros eventos ligados ao seu trabalho, ele precisa ir regularmente para a cidade para sacar seus proventos, o que lhe permite fazer compras nos núcleos

\footnotetext{
${ }^{56} \mathrm{Na}$ relação entre indígenas, não encontrei qualquer indício de pagamento por serviços entre pessoas assalariadas e não-assalariadas. De todo modo, mesmo se existir esse tipo de relação, ela, por si só, não é sinônimo de uma completa monetarização do sistema de trocas, nos moldes dos não-indígenas. Sobre essa questão, Alcida Rita Ramos afirma o seguinte: “Até nos casos em que membros de um grupo tribal trabalham para membros de outro grupo em troca de pagamento, isso nunca chega a se constituir em relações de exploração unilateral. Existe sempre nessas situações um mínimo de equilíbrio entre o que é dado e o que é tomado, de modo a inibir a negação de um grupo pelo outro. Seus interesses são suficientemente semelhantes, para tornar inviável, ou sem sentido, um tipo de exploração que levasse ao extermínio, físico ou étnico, de um grupo pelo outro." (Ramos, 1980 :13)

${ }^{57}$ A família de Orengô é composta por ele, a esposa mebengôkrê e seus cinco filhos, ocupando todos uma mesma casa. Essa não é, contudo, a configuração geral das casas de Kawerêtxikô. O mais comum é uma residência idealmente uxorilocal, ou seja, os recém-casados, antes de terem o primeiro filho, residem na casa dos pais da noiva. Depois do nascimento do primeiro filho, o casal pode se mudar e construir sua própria residência. Orengô, de todo modo, não possui ainda nenhum filho ou filha em idade de casar: Okêtê, seu primogênito, tem 13 anos. Dou ênfase ao termo idealmente pois vários homens da aldeia Kawerêtxikô me disseram que essa regra de residência uxorilocal é relativizada visando sempre aumentar o número de moradores da aldeia.
} 
urbanos da região - e, consequentemente, lhe dá menos tempo de trabalho, por exemplo, na roça.

Esse contato mais próximo de alguns Tapayúna, como Orêngo, com as cidades vizinhas não significa, é claro, uma perda progressiva da identidade étnica. Como exemplificam Cardoso de Oliveira (1978) e Ramos, (1980), o fato de frequentar cidades ou mesmo de residir nelas não é sinal de ruptura dos laços étnicos. Assim, ao se referir aos Terena, Cardoso de Oliveira afirma que:

com a progressiva urbanização dos núcleos populacionais neobrasileiros, isto é, com a formação das cidades, tanto índios aldeados como destribalizados passaram a ser atraídos por elas, a ponto de numerosas famílias se instalarem nas áreas urbanas e suburbanas e nelas residirem a custa de suas ocupações citadinas. Apesar de destribalizados e urbanizados, esses Terena continuaram a se manter ligados às suas aldeias de origem, (a) identificando-se com elas, (b) nelas mantendo "lotes" e (c) a elas retornando quando as atividades profanas [não-cristãs] ou dos rituais religiosos do "Oheokoti" [festa anual de culto aos antepassados]. (Cardoso de Oliveira, 1978 :29-30).

De modo semelhante, Ramos, em sua análise das relações entre os Sanumá e os Maiogong mostra que os primeiros tem acesso aos bens industrializados dos nãoindígenas por intermédio dos últimos. Os Maiogong fazem constantes viagens e negócios com os não-indígenas de centros urbanos daquela região sem necessariamente colocar em risco sua identidade étnica (Ramos, 1980 :23-66).

Em outra ocasião, ainda no início do ano de 2014, agora numa discussão mais formal na Casa dos Homens, debatia-se o fato do cacique Roptyktxi já estar há três dias em Piaraçu e ainda não ter conseguido pegar o dinheiro da balsa para comprar mercadorias para a comunidade da aldeia de Kawerêtxikô. Nessa reunião, Txuakrê, um homem Mebengôkrê casado com uma mulher tapayúna ${ }^{58}$, argumentava indignado que quando um cacique de uma aldeia mebengôkrê ia para Piaraçu no mesmo intuito

\footnotetext{
58 Txuakré foi diretor da Escola Goronã até o mês de janeiro de 2015, sendo então substituído na função pelo tapayúna Wengroi.
} 
que Roptyktxi, ele voltava ainda no mesmo dia com as compras feitas. Segundo Txuakrê, essa demora só podia ser explicada por um tratamento desigual dispensado aos Tapayúna pelos Mebengôkrê no recolhimento do dinheiro da balsa.

Cerca de dois dias depois dessa discussão, o cacique Roptyktxi voltou de Piaraçu, aproveitando uma carona no barco da saúde que levava uma enfermeira para Kawerêtxikô. Orengô, na casa de quem eu ainda residia, ficou acompanhando a situação do cacique na cidade pelo rádio da farmácia. Roptyktxi se dizia envergonhado por ter que esperar tanto tempo o dinheiro da balsa. Ele voltava sem dinheiro e sem ter conseguido fazer as compras para a aldeia. No entanto, ele informou que havia outros caciques em Piaraçu, também esperando o dinheiro, inclusive caciques de aldeias mebengôkrê. Essa constatação de Roptyktxi colocou em xeque a fala indignada de Txuakrê na medida em que, naquele momento, nem mesmo os próprios Mebengôkrê de outras aldeias estavam recebendo qualquer dinheiro da balsa. Alguns dias depois da tentativa frustrada, Roptyktxi voltou à Piaraçu, dessa vez acompanhado de Nokêrê, uma reconhecida liderança tapayúna, e conseguiu finalmente receber o dinheiro e fazer a compra para Kawerêtxikô,

Nesse ponto, já é possível perfazer aqui a opinião geral, tanto dos Mebengôkrê de fora de Piaraçu como também de outros grupos, incluíndo os Tapayúna, sobre a balsa. Todos com quem conversei, de dentro ou fora de Kawerêtxikô, preferiam que a balsa continuasse sendo administrada por indígenas do que voltar ao controle do governo do Mato Grosso, pairando sobre essa opinião nenhuma voz discordante.

Contudo, isso não isenta os Mebengôkrê de Piaraçu de críticas quanto à administração do dinheiro da balsa. Entre os anos de 2012 e 2015, período de minhas incursões a campo, havia uma crítica unânime, partilhada pelas diferentes etnias da região. Todos tinham consciência que se a administração da balsa fosse feita por nãoindigenas não haveria sequer a possibilidade de se barganhar algum provento em dinheiro para ajudar as aldeias na Terra Indígena Capoto Jarinã. Também não seria possível garantir aos transeuntes indígenas o pagamento das passagens na linha de ônibus regular. O que se debatia, é preciso deixar claro, não era a possibilidade de acabar com a administração indígena da balsa, feita pelos Mebengôkrê de Piaraçu, mas uma reforma ou mudança na gestão do dinheiro coletado. A crítica comum dizia respeito à concentração da renda da balsa na aldeia Piaraçu, em detrimento das outras aldeias da Terra Indígena Capoto Jarinã e não obedecia a um recorte étnico 
determinado na medida em que também era compartilhada pelos Mebengôkrê das outras aldeias.

Essa crítica apareceu claramente em uma outra discussão na Casa dos Homens de Kawerêtxikô, ocasião em que se debatia o uso do dinheiro da balsa para comprar um motor de popa de $15 \mathrm{hp}$ para a aldeia. Pretendia-se comprar um motor usado, já que um outro motor novo, doado pela Secretaria Especial de Saúde Indígena (SESAI), através do DSEI Kayapó, utilizado principalmente na transferência de doentes, havia sido roubado em Kawerêtxikô, na beira do rio Xingu. Esse motor era usado para transferir doentes não só da aldeia dos Tapayúna, mas também dos moradores mebengôkrê da região adjacente à Kawerêtxikô - principalmente das localidades vizinhas de Kromari e Bytire.

Durante toda essa discussão, pairava sobre a aldeia dos Tapayúna um rumor difuso que atribuía a um homem mebengôkrê de uma aldeia vizinha o roubo do motor doado e sua venda para um grupo do Alto Xingu. Esse homem tinha má reputação mesmo entre os Mebengôkrê. Ele era um antigo morador do Metyktire. Dizia-se que ele sempre andava armado com armas de fogo de grosso calibre e era, sabidamente, uma pessoa sempre metida em confusões - descrição que lembra muito o estereótipo dos não-indígenas do Bangue. Ele já havia sido expulso da aldeia Metyktire por ter ameaçado um outro Mebengôkrê de morte com uma arma de fogo. Pude encontrá-lo uma vez no posto-de-saúde de Kawerêtxikô, onde levava seu filho para tratar de um corte na perna. Assim que ele saiu do local, um dos moradores de Kawerêtxikô, presente na ocasião, comentou comigo se referindo a este homem que acabava de sair: "ele ainda vai achar uma espingarda de índio pra explodir na cara dele."

Nesse encontro na Casa dos Homens, Roptyktxi trouxe um papel que circulava entre todos os presentes. Era um documento manuscrito que ele tinha trazido da aldeia do Meytktire, assinado, entre outros, por Raoni, o cacique daquela aldeia e a grande liderança indígena da região. Nesse documento, escrito em letra de forma à caneta azul em papel A4 branco, dizia-se, em Português, que o cacique Raoni autorizava os Tapayúna a pegar dinheiro na balsa na sexta e no sábado próximos para a compra do referido motor. Esse papel passava de mão em mão e eu e todos os cerca de vinte homens que estavam na Casa dos Homens o leram - ao menos aqueles que dominavam a leitura em Português. Enquanto o documento circulava, discutia-se como o dinheiro seria pego na balsa. Esse tema específico do motor foi discutido 
durante cerca de quatro noites consecutivas na Casa dos Homens, nas línguas Kaykwakhratxi e Mebengôkrê. Até meus últimos dias em campo não se havia conseguido angariar a tal verba para o motor, que ainda não havia sido comprado.

Durante toda essa discussão em torno da compra do motor, a tendência à concentração da renda da balsa na aldeia Piaraçu às expensas das outras aldeias da Terra Indígena Capoto Jarinã era assunto recorrente. Segundo informações de diversos homens mebengôkrê que falam Português, o chefe da balsa é uma indicação do cacique Raoni. Uma vez escolhido, esse chefe indica o séquito que irá trabalhar com ele, organiza o pagamento das despesas fixas (óleo diesel, gasolina, etc.) e a manutenção periódica da balsa, além de ser responsável pela divisão do dinheiro coletado com as outras aldeias. Não tive condições de mapear o jogo político que, com certeza, alicerça essa escolha, que não passa apenas pela indicação direta e unilateral de Raoni. É importante lembrar, no entanto, que os Tapayúna não são os únicos descontentes com a atual gestão dos recursos oriundos da balsa. Mesmo nas aldeias mebengôkrê existe uma forte oposição à maneira pela qual o dinheiro que entra diariamente dos fretes que os não-indígenas pagam para atravessar o rio Xingu é divido.

Sugiro que essa posição predominante dos Mebengôkrê de Piaraçu só não é completamente insustentável pelo fato dos Mebengôkrê estarem gerindo a balsa dentro de suas terras tradicionais. Na aldeia Kawerêtxikô, boa parte dos cerca de cento e cinqüenta moradores são homens mebengôkrê que casaram-se com mulheres tapayúna ou, ao contrário, mulheres tapayúna que casaram-se com homens mebengôkrê. Esses casais formaram-se ainda na época em que os Tapayúna residiam conjuntamente com os Mebengôkrê do Metyktire. Os homens ou mulheres tapayúna que se casaram anteriormente com os Kinsedje permaneceram, geralmente, entre esses últimos e não se mudaram para a região dos Kayapó.

Os casamentos entre Tapayúna e Mbengôkrê, pelos dados que pude recolher, funcionam menos para manter uma hegemonia dos Mebengôkrê e são mais uma estratégia dos próprios Tapayúna para conseguir se reproduzir socialmente, já que chegaram ao PIX compondo apenas cerca de 40 pessoas, sendo boa parte delas crianças. O matrimônio com outros povos indígenas que já residiam no Parque foi a única opção que os sobreviventes falantes de Kaykwakhratxi encontraram para conseguir existir no PIX. Nesses casos extremos de depopulação, eles podem 
facilmente atualizar as regras sociais. Por exemplo, a regra de residência uxorilocal dos Tapayúna, que vigora até o nascimento do primeiro filho, pode ser relativizada para possibilitar o aumento populacional da aldeia Kawerêtxikô. É possível fazer, neste ponto, um outro interessante paralelo com a situação dos Terena analisados no primeiro capítulo de $A$ sociologia do Brasil indígena (Cardoso de Oliveira, 1978):

Os Terena aldeados estavam prontos a dizer que "os filhos(as) seguem o Pai”, isto é, tomam a metade paterna; mas quando eram chamados a informar sobre a situação dos descendentes de casamentos interétnicos, imediatamente os identificavam com a metade do membro Terena da união, mesmo que este fosse do sexo feminino. (idem :24)

Assim, tanto as regras de descendência dos Terena, como as regras de residência dos Tapayúna, podem ser manipuladas para se adaptar às situações políticas que lhes assegurem alguma vantagem relativa em determinado contexto histórico. Os Mebengôkrê residentes em Kawerêtxikô e casados com Tapayúna se comportam, ao menos em relação à questão da balsa, como os próprios Tapayúna. Assim, eles fazem críticas severas aos Mebengôkrê de Piaraçu e interpelam constantemente a administração da balsa por uma divisão mais equânime do dinheiro recolhido, como o caso da crítica, ainda que infundada, feita por Txuakrê.

Contudo, é importante ressaltar, fazer parte da etnia que é considerada tradicional da região, mesmo quando se reside em uma aldeia de outro povo, não é desprezível no nível das relações interaldeias. Assim, qualquer que seja sua aldeia de residência, é mais vantajoso e prestigioso, por exemplo, ser mebengôkrê que tapayúna na Terra Indígena Capoto Jarinã já que você nunca será visto como um estrangeiro ou um recém-chegado e que e seu idioma é a língua franca de comunicação entre os diversos grupos.

Para terminar, é necessário deixar claro, mais uma vez, que não há qualquer sinal de um 'corporativismo étnico' que atuaria a favor dos Mebengôkrê na distribuição do dinheiro da balsa. Como vimos, os Mebengôkrê residentes em Kawerêtxikô fazem críticas até mais pesadas aos seus do que os próprios Tapayúna. O caso que relatei nas paginas anteriores, do ex-diretor da Escola Goronã, o 
Mebengôkrê Txuakrê Metyktire ${ }^{59}$, que questionava a divisão do dinheiro da balsa por favorecer os Menbengôkrê em detrimentos dos Tapayúna, é apenas um exemplo. Como vimos na exposição desse caso, a viagem do cacique Roptyktxi à Piaraçu provou que essa acusação não era verdadeira e que não se tratava de um favorecimento a uma etnia em particular. Os filhos de Txuakrê e sua esposa residem, todos, na aldeia tapayúna e, nesse caso específico, como em outros, o local de residência e os laços comunitários que ligam as pessoas a uma determinada aldeia são mais importantes que a filiação linguística ou o pertencimento étnico mais direto.

Com isso, não estou argumentando que os Mebengôkrê, casados com Tapayúna e que vivem em Kawerêtxikô, estão se transformando em Tapayúna, mas simplesmente que, em algumas situações específicas, como no caso da distribuição do dinheiro da balsa, o critério relevante usado pelos moradores dessa aldeia não é o pertencimento étnico, mas o lugar de residência. Se os moradores de Kawerêtxikô se sentem lesados na distribuição do dinheiro da balsa não é pelo fato deles serem, em sua maioria, Tapayúna ou descendentes, mas sim por residirem em uma aldeia que não participa da administração dos recursos financeiros oriundos da balsa.

Embora o pertencimento étnico não seja relevante na situação específica da divisão da renda da balsa, já que todos os moradores de aldeia Kawerêtxikô são tratados da mesma maneira, independente de etnia à qual pertencem, seria precipitado concluir que o critério étnico não opera em outras situações. A identidade tapayúna é acionada, por exemplo, pelas lideranças de Kawerêtxikô para pedir produtos e benfeitorias ao Instituto Raoni. Essa organização não-governamental, sediada na cidade de Colider, foi fundada, em grande medida, em decorrência da fama nacional e internacional do cacique do Metyktire. Contudo, ela presta serviço não só aos Mebengôkrê, mas também aos Tapayúna e a outros grupos do PIX. Nas negociações com o Instituto Raoni, os Tapayúna de Kawerêtxikô acreditam que é mais vantajoso, para eles, acionar sua identidade étnica e não seu lugar de residência.

O critério étnico também pode ser acionado para caracterizar a aldeia Kawerêtxikô em outras situações que não as relacionadas com a balsa. Embora ela possa ser considerada como uma comunidade multiétnica, já que muitas famílias

\footnotetext{
${ }^{59}$ Há de se notar que os Mebengôkrê, normalmente, não usam este último termo para registrar seus sobrenomes: como Txuakrê, eles preferem fazer referência à aldeia em que nasceram ou foram criados. Tal fato, mais uma vez, corrobora a já descrita independência das aldeias na TI Capoto Jarinã.
} 
residentes são compostas por Tapayúnas e Mebengôkrê, Kawerêtxikô é geralmente apresentada pelas lideranças locais como uma aldeia Tapayúna. A Escola Estadual Goronã, por exemplo, leva um importante nome da mitologia tapayúna e é tida como uma instituição de ensino deles próprios, como demonstrarei no próximo capítulo. $\mathrm{Na}$ realidade, essa aldeia e seus moradores estão inseridos num complexo jogo de relações políticas interétnicas, onde múltiplas identidades podem ser acionadas em função do contexto social. Como mostrou Barth (1969), a identidade étnica é sempre situacional ou relacional, nunca fixada, e pode ser ativada em certa situação e ignorada em outras pelas pessoas envolvidas em cada circunstância específica. Antes dele, Evans-Pritchard (2013) já havia chamado atenção para as múltiplas identidades, por vezes até contrastivas, que perpassam a vida dos indivíduos, ainda que numa sociedade dita 'simples'.

Assim, para um indígena Mebengôkrê residente na comunidade Kawerêtxikô, a aldeia pode ser apresentada como uma comunidade "quase-que-tipicamenteMebengôkrê" já que ela está localizada em território tradicional Mebengôkrê. Por sua vez, um Tapayúna, falante da língua Kaykwakhratxi, argumentaria que Kawerêtxikô é uma aldeia "tipicamente tapayúna" e ressaltaria para fundamentar seu argumento que a criação dessa aldeia se deu justamente para diferenciar os Tapayúna dos Mebengôkrê do Metyktire, tendo os primeiros se emancipado e se mudado para um aldeia própria. Assim, nesse caso e na perspectiva dos Tapayúna, o critério étnico se torna extremamente relevante e permite estabelecer uma distância entre Kawerêtxikô, vista como uma aldeia tapayúna, e outras aldeias da região como o Metyktire ou Piaraçu que são consideradas aldeias Mebengôkrê. Todos os Tapayúna de Kawerêtxikô são enfáticos em afirmar que fundaram essa aldeia para evitar a convivência diária com os Mebengôkrê de Metytire. Queriam, assim, edificar uma aldeia deles mesmos, onde seus filhos pudessem, entre outras coisas, ser socializados como Tapayúna e alfabetizados em língua Kaykwakhratxi.

Kawerêtxikô, como todas as outras aldeias da região, preserva sua autonomia econômica e política e essa autonomia é respeitada pelos vizinhos. Essa alto grau de independência de cada aldeia não inviabiliza as relações entre elas, mas é um princípio fundamental e parece ser a pedra de toque das relações interétnicas e interaldeias na Terra Indígena Capoto Jarinã. Muito mais que o pertencimento étnico, é essa autonomia local das aldeias que torna extremamente difícil que seja 
implementada uma distribuição mais simétrica dos recursos da balsa entre as diferentes aldeias. Situada nas proximidades da aldeia Piaraçu, a balsa é controlada por homens mebengôkrê dessa comunidade. Embora os representantes de outras aldeias da região, inclusive os moradores Kawerêtxikô, tenham o direito de reclamar de injustiças na distribuição dos recursos da balsa e possam exercer certa pressão sobre os administradores, o princípio de autonomia de cada aldeia é respeitado e impõe limites a essas reivindicações.

É dentro desse contexto sociológico regional extremamente diverso e dinâmico que vivem os Tapayúna de Kawerêtxikô. Como procurei mostrar neste capítulo, suas relações históricas com os não-indígenas, iniciadas durante a colonização da região, foram caracterizadas por práticas etnocidas que quase levaram ao genocídio desse povo. Essas relações dos Tapayúna com os não-indígenas diferem profundamente das relações que eles construíram, após sua transferência forçada para o PIX, com os outros povos indígenas da região. As relações entre indígenas também não são simétricas. Como o caso da distribuição dos recursos oriundos dos pagamentos dos não-indígenas para a travessia do rio Xingu mostra claramente, existe uma hierarquia na região que confere aos Mebengôkrê, considerados habitantes tradicionais, uma posição privilegiada em relação aos outros povos. No entanto, esse predomínio dos Mebengôkrê não impossibilita uma convívio pacífico e uma certa simbiose nas relações sociais cotidianas. Essas relações são muito diferentes do autoritarismo, por vezes genocida, que marcou o contato dos Tapayúna com os nãoindígenas. Como mostrarei nos capítulos seguintes, essas diferentes relações interétnicas, tanto com não-indígenas como também com outros indígenas, marcaram e ainda marcam claramente a Escola Goronã e o posto-de-saúde. 


\section{Capítulo 3. Uma etnografia da educação formal entre os Tapayúna}

A Escola Estadual Goronã tem cerca de 70 alunos, alocados em turmas mistas de diferentes séries do ensino fundamental, do $1^{\circ}$ ao $9^{\circ}$ ano. Depois de cursar tais séries, os estudantes da aldeia que pretendem continuar o ensino formal precisam se mudar ou viajar diariamente para Piaraçu, localidade em que existe uma instituição de ensino médio. Os cargos disponíveis na escola de Kawerêtxikô são os seguintes: diretor, coordenador pedagógico, quatro professores, merendeiro e segurança.

$\mathrm{Na}$ fundação da Escola Estadual Goronã há toda uma narrativa de como os Tapayúna conseguiram efetivá-la. De maneira geral, vários jovens homens, como os professores Orengô e Wengroi ou o antigo diretor Txuakrê, confirmam que sua fundação foi um desejo de que a educação formal, entre eles, não fosse um "anexo" da escola do Metyktire, aldeia Mebengôkrê onde os Tapayúna viveram por alguns anos, como descrito no capítulo anterior. Orengô, sobre esse tema, diz que:

A gente queria mesmo uma escola nossa, aqui do pessoal da gente mesmo, Tapayúna. Não queria anexo, não. Maria Eliza [então funcionária da Funai] e Nayara [linguista] sabem, elas ajudaram a gente a fazer do jeito que a gente queria. Teve que viajar pra Cuiabá [capital do Mato Grosso] pra entregar documento; teve que viajar pra Peixoto [Peixoto de Azevedo, um núcleo urbano de peso regional no norte do Mato Grosso] pra entregar documento. Maria Eliza tem guardado cópias dos documentos da gente abrir a Escola [Goronã].

Assim, os moradores de Kawerêtxikô queriam evitar que a escola dos Tapayúna fosse dependente dos Mebengôkrê - e o que acabaram, realmente, conseguindo, apesar da relativa hegemonia desse último grupo.

Caso a Escola Goronã fosse um "anexo", uma das principais conseqüências seria ter que receber professores indígenas oriundos de outras localidades e, além disso, não existir, é claro, os cargos de diretor ou coordenador pedagógico, que só estariam disponíveis no local onde a escola principal fosse instalada. Tão pouco seria 
possível discutir o Plano Político Pedagógico (PPP) com as lideranças de Kawerêtxikô, como era feito comumente. A Escola Goronã é, nesse sentido, um exemplo de apropriação de uma tradição de conhecimento exterior muito próximo ao que a antropóloga Antonella Tassinari chama de zona de fronteira (Tassinari 2001a e 2001b). Contudo, deve ficar claro que a categorização da Escola Goronã como tipicamente tapayúna passa por outras questões, para os moradores de Kawerêtxikô, que não apenas o caráter diferenciado que ela pode ou não apresentar.

O PPP foi debatido comigo em uma ocasião especial: dentro da casa de Orengô, quando eu ainda residia com ele e sua família. Orengô, Txuakrê, Wengroi e eu discutimos como melhorar o texto do PPP. Eu fiz uma revisão geral do Português e, depois disso, fomos discutindo ponto a ponto o que os Tapayúna queriam modificar na redação ou adicionar no PPP. Em certo momento, os jovens homens que discutiam esse documento comigo ficaram em dúvida se poder-se-ia ou não colocar no calendário geral uma importante festa da aldeia Kawerêtxikô. Resolveu-se, então, aumentar a reunião e "chamar os mais velhos" (Orengô) da aldeia: o cacique Roptyktxi, o pajé Wotkàtxi e o professor Nokêrê. Com a anuência desses três Tapayúna, eu, Wengroi, Orengô e Txuakrê fizemos algumas modificações no texto do Plano Político Pedagógico da Escola Goronã. Colocamos um capítulo mais detalhado sobre a história recente dos Kaykwakhratxi; abrimos espaços no calendário para a comemoração de alguns dias importantes de festas para os Tapayúna, como uma festa de colheita, preparação e consumo ritualizado de produtos como o beiju e a farinha de mandioca. Além disso, reservamos alguns dias do mês de setembro para o plantio da roça.

Contudo, por conselho tanto dos homens jovens quanto das lideranças tradicionais que haviam sido chamadas, não modificamos, por exemplo, o total de dias letivos, algo que os funcionários da Secretaria de Educação do Mato Grosso (Seduc-MT) haviam dito para os Tapayúna que não poderia sofrer nenhuma adaptação. Assim, o calendário, apesar de conter algumas mudanças feitas a partir do contexto sociológico de Kawerêtxikô, ainda contava com os 200 dias letivos mínimos que a Seduc-MT exigia para que a Escola Goronã continuasse funcionando.

Deixo claro, portanto, que a Escola Estadual Goronã é tida, pelos habitantes da Kawerêtxikô, como uma escola dos Tapayúna - e não para os Tapayúna. Isto não exatamente porque ela é diferenciada, respeitando totalmente a língua e os costumes 
dos Tapayúna como proposto na Constituição de 1988, tema já apresentado e discutido no capítulo 1. Porém, mais diretamente, porque ela não é "anexo" de nenhuma outra escola mebengôkrê da região. Por "anexo" entende-se, assim, uma escola fisicamente independente, mas com todo o corpo de funcionários advindo de uma outra instituição de ensino, localizada em outra aldeia.

A Escola Goronã emprega os homens Tapayúna e Mebengôkrê residentes em Kawerêtxikô e que são todos assalariados da Seduc-MT. Como no caso da luta política descrita entre as famílias extensas Ava Kaiowá por Tonico Benites (2009), os Tapayúna se organizaram para que a educação formal na aldeia Kawerêtxikô não estivesse submetida à qualquer outra escola, mais pontualmente a uma escola controlada por uma família extensa mbengôkrê. Como mostrarei, isso não impede que os homens da última etnia trabalhem na Escola Goronã.

Desta maneira, a escola de Kawerêtxikô não é exatamente o que se pode chamar de uma instituição de ensino completamente adaptada ao contexto dos Tapayúna. Para citar alguns outros exemplos de como a Escola Goronã não se enquadra totalmente na noção de uma escola diferenciada, além da exigência já citada dos 200 dias letivos, a Seduc-MT impõe que os Tapayúna devam apresentar, anualmente, um Plano Político Pedagógico (PPP) no modelo exigido para todas as escolas da rede estadual de ensino (mesmos capítulos e divisão geral), o qual deve ser escrito, obrigatoriamente, em Português. Cada um dos professores indígenas precisam apresentar planos de aula, sob a mesma condição obrigatória, também obrigatoriamente em Português.

Há, inclusive, visitas periódicas de funcionários da Seduc-MT à aldeia Kawerêtxikô para conferir se tudo anda como o exigido. Nessas ocasiões, os Tapayúna tentam se organizar da maneira que, para eles, a Seduc-MT gostaria que eles organizassem o ensino formal. Assim, no período de visitas, o horário de aulas é observado com mais rigidez, interpela-se pontualmente os estudantes faltantes para assistir as aulas e apressa-se em terminar, com a ajuda do antropólogo em campo, documentos que por ventura estejam pendentes, como os já citados planos de aula ou uma nova versão do Plano Político e Pedagógico da Escola Goronã.

Essa cobrança é, no mínimo, um descaso explícito dos funcionários nãoindígenas da Seduc-MT com legislação que garante uma educação formal diferenciada aos indígenas no Brasil. No caso dos Panará, outro povo indígena da 
mesma região dos Tapayúna, que também possuem uma escola independente nos moldes da Escola Goronã, uma liderança me disse, em um curso para professores indígenas da Funai em 2012 na aldeia mebengôkrê de Piaraçu, que eles estavam sendo obrigados a inserir, nas datas comemorativas do calendário escolar, eventos como a festa de São João, o Dia das Mães ou o Natal. Os Panará, ainda segundo essa liderança, se negaram a efetivar tais festividades. Na mesma linha, os Tapayúna dizem que também se negaram a organizar aulas de ensino religioso ou comemorar datas do calendário cristão nacional, uma exigência inicial que foi, mais tarde, descartada pela Seduc-MT para efetivar a Escola Goronã. Isto deve ter se dado, possivelmente, pela assessoria da Funai e de outros não-indígenas e indígenas conhecedores das premissas legais. Assim, o processo de laicização do Estado brasileiro brevemente descrito no capítulo 1 teve, por fim, alguma influência positiva no cotidiano da vida dos indígenas da região.

Já argumentei que a Escola Goronã, o posto-de-saúde (também chamado de farmácia) e a Casa do Antropólogo são as únicas três construções que estão fora do círculo da aldeia Kawerêtxikô. Há, porém, uma característica que ainda não explorei e que, em vez de trazer uma similitude - as construções ocupam um lugar semelhante, fora do círculo - traz, na verdade, uma diferenciação quando comparamos a Escola Goronã com a farmácia. Esta última, como se pode notar, não tem um nome específico, enquanto a primeira leva um nome bastante importante na mitologia tapayúna, como mostrarei a seguir. Os postos-de-saúde das outras aldeias da região seguem a mesma lógica: por exemplo, na aldeia mebengôkrê de Piaraçu, o ensino formal tem suas aulas na Escola Bepkororotxi, nome de uma importante liderança. O posto-de-saúde ou farmácia, como em Kawerêtxikô, não leva qualquer nome específico e é sempre tratado de maneira genérica. No máximo, quando se faz referência àquela farmácia determinada, se diz em qual aldeia ela se localiza, mais nada além disso. Tal fato vale também para a farmácia de Kawerêtxikô e das diversas aldeias da região.

Na próxima sessão, farei uma apresentação e contextualização do nome em Kaykwakhratxi que leva a instituição de ensino formal dos Tapayúna. Depois, passarei a apresentar algumas peculiaridades da Escola Goronã de Kawerêtxikô. Com isso, farei uma etnografia das aulas de ensino formal que acontecem nessa instituição. 
Por fim, discorrerei sobre o contexto geral do letramento, entre outras técnicas nãoindígenas, entre os Tapayúna.

\subsection{A origem dos nomes próprios: goronã e o englobamento do contrário}

O cacique da aldeia Kawerêtxikô, Ropyktxi Tapayúna, foi gravado em áudio e vídeo enquanto explicava, em língua Kaykwakhratxi, o mito em torno do nome goronã no ano de 2014. Filmado por um outro Tapayúna, este último deixou que eu copiasse o vídeo no meu laptop. Acabei perdendo o arquivo, mais tarde, em uma falha do hard disk interno do meu computador. De todo modo, esse arquivo está gravado em um hard disk externo de um projeto de documentário que é coordenado, atualmente, pela antropóloga Daniela Batista de Lima, na aldeia Kawerêtxikô. Orengô Tapayúna, Têtô Tapayúna e Kakhrãtxi Tapayúna fizeram a tradução a meu pedido, usando meu laptop, carregado por células solares em Kawerêtxikô, para ouvir a gravação de Roptyktxi enquanto eu tomava notas do que eles traduziam para o Português. O mito foi transcrito, assim, em um de meus cadernos de campo. A ideia inicial era fazer uma legenda em Português para o vídeo. Então, em minhas notas, toda a transcrição está submetida ao tempo da gravação - ao todo o vídeo tem pouco mais de 14 minutos. Contudo, na versão que agora apresento, eliminei essas referências ao tempo e, em algumas passagens, adaptei a transcrição para figurar mais acertada à construção textual em Português. As informações entre colchetes foram explicadas a mim por Orengô Tapayúna, numa revisão do texto que tínhamos acabado de produzir.

\section{Goronã e a conquista dos nomes próprios}

As pessoas, antigamente [em um tempo mitológico], faziam festas [de uma forma errada]. Há uma festa [correta] que se chama Ngejtwâj. Essas pessoas não tinham nomes [próprios, individuais]. Todo mundo se chamava apenas de jajthẽktxi $e$ goronã. E, nas festas, essas pessoas só se chamavam desses nomes. Eles pensavam que não tinham nomes [próprios]. O marido chamava a esposa de goronã. $O$ marido era chamado de goronã. 
Havia outro povo que se chamava kuwẽkrôtxi [povo que mora dentro da terra]. Esses só conviviam com eles mesmos. Viviam antigamente. Essas pessoas dançavam em volta de suas casas.

Um deles [dos kuwẽkrôtxi] levou uma cabaça de volta para a casa, no meio da madrugada. Ele matou um rapaz [da superficie] que dançava com o chocalho e levou [o corpo do rapaz] de volta para a casa [embaixo da terra]. A mãe e avó [do morto] estavam ouvindo, preocupados. Eles não ouviam mais o homem que cantava. Se preocuparam.

Os velhos [avós do rapaz morto] não conseguiam dormir e ouviram quando mataram o rapaz. O rapaz deixou a cabaça cair e os velhos ouviram esse barulho. Eles gritaram para todo mundo: "venham que nosso filho está dormindo e deixou a cabaça cair".

Todos estavam dormindo e não ouviram. Assim, mataram o rapaz e levaram para a casa do buraco. Quando amanheceu, os outros procuraram o rapaz. "Cadê nosso colega?", diziam. Eles viram o rastro de sangue e seguiram. Não conseguiram achar o lugar e voltaram.

Foram os outros indios que mataram o rapaz. Eles contaram pra seus companheiros. Eles diziam: "é verdade". Eles voltaram a seguir o rastro. Eles se pintaram de preto e foram até lá [para fazer guerra].

Eles acharam o rapaz [morto]. Todo mundo se pintou. Foram até onde o rapaz estava. Viram o buraco. Os velhos que conheciam esses indios disseram que eles eram os kuwẽkrôtxi [povo que mora dentro da terra]. "Mataram nosso colega. O que vamos fazer?"

"Vamos acender fogo [de matar tatu] em cima do buraco deles. A fumaça matará eles." Lá havia outra saída. Eles colocaram pau e atearam fogo, abanando o fogo. "Pode abanar o fogo." Viram a fumaça e o povo do buraco saiu pela outra saída [que até então os da superfície não conheciam]. Eles perguntaram: "quem vai entrar no buraco?". O irmão do rapaz que morreu entrou no buraco para ver esse povo.

Todos falaram para ele: "você não pode ter medo". Amarram nele um cinto de embira [tradicional cipó da região] e ele entrou. Logo encontrou o caminho. Viu depois um caminho melhor. Foi caminhando como o caminho do rio [com curvas]. Como a gente anda no mato [picadas não-lineares]. Ai ele viu a casa. Eles [os kuwẽkrôtxi] estavam dançando em volta da casa, cantando as músicas Ngejtàtxrêrê, Ngejgontó, Ngejtoj ndó wata. Ele [o irmão do morto] viu o enfeite de plumas brancas de aves, bem grande, no centro da aldeia. Ele [o da superficie] estava andando, entrando em cada casa. Só que não tinha nada. Eles [da superfície] puxaram a embira e ele [o irmão do homem morto] voltou [para a superficie]. Os outros puxaram ele.

Eles perguntaram: “como é lá?”. Ele respondeu: "todo o povo já foi [dançar, em referência às casas vazias]. Há outra saída.". Todos voltaram para sua aldeia [da superficie]. Eles viviam na própria aldeia deles. Esses índios [do buraco] demoraram pra voltar. O pessoal [da superficie] já fazia festa de novo. Eles [da superficie] já haviam retornado para sua aldeia quando os kuwẽkrôtxi mataram outro rapaz. Eles mataram outro rapaz da mesma maneira [que havia acontecido antes]. Eles bateram nele enquanto ele dançava. O chocalho caiu e fez barulho. Outros falaram: "seu filho dormiu, deixando o chocalho cair".

Começaram a dançar, só que não estavam dançando [fingindo dançar]. E de dia eles acharam o sangue. "Eles mataram nosso irmão." E todos foram ver. "Foi 
kuwẽkrôtxi [povo que mora dentro da terra] que matou”. Eles [da superficie] construíram novas casas e deixaram o lugar antigo [se mudando de aldeia].

Eles [da superficie] procuraram a outra saida. Acompanharam o sangue. Todos procuraram a outra saída e não acharam. Tentaram mais e descobriram a outra saída. Os kuwẽkrôtxi [povo que mora dentro da terra] não sabiam e gritavam dentro do buraco. Eles haviam achado a outra saída. Eles [da superficie] fecharam o buraco, a outra saída. Fecharam aquela e fecharam a outra. Eles começaram a juntar paus para acender o fogo, abafando. Eles [kuwẽkrôtxi] viram a fumaça e escutaram o barulho. Continuaram [os da superficie] abafando o fogo. Os kuwẽkrôtxi procuraram outra saída. Assim, a fumaça matou todo mundo do kuwẽkrôtxi.

Eles [da superficie] falaram: "vamos esperar a fumaça acabar. Alguém pode entrar quando a fumaça acabar." Quando acabou a fumaça, um entrou. Ele encontrou todos mortos. Eles tinham o rosto pintado. Ele andou até encontrar seu filho [criança originalmente kuwẽkrôtxi, cativa de guerra], que estava dentro de uma panela de barro grande. Ele viu seu filho e o menino chorou, olhando para cima. Eles falaram: "não pode chorar" e pegaram o menino pelo braço, saindo para a Casa dos Homens. Eles perguntaram: "como é?", "Todos eles morreram?".

Eles o trouxeram para a aldeia. Ele andou com amigos e ficaram adultos. [o menino que havia sido pêgo dentro da panela, cativo de guerra]. A avó dele falou "Ngejtàtxêrê ngràj" [nome de uma festa]. Ele [do povo kuwẽkrôtxi] saiu e começou a festa; ele olhava os outros, que chamavam do mesmo nome crianças e adultos. Ai ele começou a dar nome para cada um: "filho de quem vai chamar Ngeimontxi?". Alguém escolheu: "eu!".

"Quem vai se querer chamar Kokotxi?"e de sua casa alguém disse: "eu vou". Assim eles cantaram com Ngei. Ele era o pai [classificatório] que iria proteger ele [o filho tirado dos kuwẽkrôtxi]. Ele [o pai] foi até lá. Ele [o filho] falou: "já dei nome aos nossos parentes". O pai dele falou: "você já nominou alguém Ngei? [prefixo que designa nomes especiais]". "Não, só Kokotxi" [respondeu o filho]. O pai foi ficando com raiva. "Porque você não nominou ninguém Ngei aqui?". Ele respondeu: "se alguém, irmão ou irmã nosso, tiver filhos, o chamaremos de Ngei." Eles [os familiares do jovem de origem kuwẽkrôtxi] ficaram com raiva e bateram nele [no jovem kuwẽkrôtxi]. Ele ficou chorando. A avó dele pegou ele e o levou de volta para a casa.

Enquanto isso, o pessoal dançava. Eles dançavam a festa do Ngei. Eles perguntaram ao filho dos kuwẽkrôtxi: "como se faz essa festa?". Ele falou: "presta atenção, vocês precisam ouvir isso.". Ai os próprios Tapayúna começaram a festa do Ngei. Ai ele falou que o canto não estava certo, xingou e corrigiu a maneira de cantar dos outros. Ele ouviu e cantou junto. Perguntaram: "quem é ele?". Disseram: "ele foi adotado, ele era aquele menino kuwẽkrôtxi [do povo que morava dentro da terra]". O homem kuwẽkrôtxi falou: "assim meu avô fazia esse canto.". Ai os Tapayúna pensaram em fazer isso também. "Isso que eu estou cantando pra vocês, Ngejmontxi... . É isso que eu ensino a vocês." Assim, quem tem nome de Kokotxi não tem festa. Só tem festa quem tem nome Ngei. Essa é a origem dos nomes. Por isso nos falamos "goronã" para as pessoas, por isso falamos "goronã" para a Escola. É isso, terminei. 
Uma leitura ainda que superficial do mito mostra que o nome goronã faz referência a uma situação mítica inicial de indiferenciação dos nomes, seguida pela entrada de um conhecimento exterior, a ser ensinado aos Tapayúna por outros povos, como os Kuwẽkrôtxi, o povo que morava dentro da terra. Esse conhecimento não é, contudo, obtido de maneira que poderíamos chamar completamente "formal": o saber da nominação, o cântico dos nomes especiais Ngei e o não festejo de nomes comuns, como Kokotxi, só é conseguido pela guerra, pela refrega com um outro povo também belicista e a apropriação posterior dos órfãos, junto com os seus costumes. Esses são, sem dúvida, os dois principais botins de guerra entre os Jê com quem tive contato na TI Capoto Jarinã: pessoas e costumes - ou, mais precisamente, pessoas com costumes diferentes.

Deste modo, o que os Tapayúna aprenderam com os Kuwẽkrôtxi foi saber que existem nomes próprios, que não se pode chamar todos os parentes pelo termo genérico "goronã", que uma tradução livre poderia aproximar da noção de "gente" em Português. Além disso, há uma graduação de nomes: há nomes mais importantes, especiais, para os quais há uma festa de nominação - também ensinada pelo jovem kuwẽkrôtxi; há, ao mesmo tempo, nomes comuns, que não precisam de festas especiais para se nominar alguém com eles.

César Gordon (2006), sobre os Xikrin do Cateté (grupo da mesma família e tronco lingüístico dos Tapayúna), no sul do Pará, analisou de maneira bastante interessante o problema na nominação especial. Tal grupo, apesar de falar uma língua próxima ao Mebengôkrê, nem sempre se alinhava politicamente aos outros falantes dessa língua. Assim, há situações em que a identidade Xikrin era mais importante que a de Mebengôkrê - o que não quer dizer, é claro, que a última identidade não fosse acionada em outras situações diferentes. De todo modo, os Xikrin também possuíam, como os Tapayúna, rituais de nominação para um grupo especial deles próprios.

Gordon mostra que existia, entre os Xikrin, um prefixo usado nos nomes das pessoas tidas como pertencentes às famílias mais importantes. A festa de nominação especial era, como entre os Tapayúna, uma ferramenta de diferenciação interna entre os Xikrin. Contudo, como bem mostra o autor no desenvolvimento de sua etnografia, esses rituais se popularizaram muito entre os Xikrin e facilmente uma família, nos dias de hoje, é capaz de patrocinar uma festa de nominação. 
Assim, as famílias xikrin mais influentes - o que não era, necessariamente, sinônimo de famílias com maior poder econômico - tiveram que construir uma outra maneira de eficazmente se distinguirem, internamente, das famílias comuns. Com isso, as lideranças reconhecidas como parte das famílias xikrin mais importantes, se apossavam e distribuíam o dinheiro pago pela mineradora Vale do Rio Doce aos Xikrin como um todo para que a primeira fizesse prospecção de minérios no território tradicional dos últimos. A distribuição desses recursos não era completamente simétrica e as famílias mais importantes conseguiam reservar parte da verba para comprar roupas e outros bens de consumo não-indígenas em grifes famosas dos núcleos urbanos da região do sul do Pará. As famílias das lideranças podiam, com isso, se diferenciar das famílias comuns por uma estratégia que não passava mais pela nominação especial - ou não exclusivamente por esses rituais. Porém, como se pode notar, essa nova práxis de diferenciação tornava as lideranças cada vez mais próximas dos não-indígenas e perigosamente distante, em termos materiais e simbólicos, já agora, dos Xikrin comuns.

O que pretendo sublinhar com tudo isso é a dinâmica de entrada de um conhecimento externo entre os Jê. A aprendizagem do novo pelos Tapayúna e outros grupos da mesma família e tronco lingüístico não teve início apenas quando eles tiveram contato com os não-indígenas. Essas populações já tinham processos sociais para dar conta de uma alteridade à qual, a priori, eles não eram aliados ou - o que quase sempre quer dizer a mesma coisa - aparentados. A guerra, como mostra o mito Goronã, teve um papel central nessa questão. Há, deste modo, uma interpretação de como englobar o Outro. É na figura de seus rituais, cânticos e outras práticas diferentes que os não-parentes adentram ao sistema social nativo: tornam-se botim de guerra por excelência.

Inspiro-me aqui, além da etnografia de Gordon, na teoria de Louis Dumont sobre a hierarquia como englobamento do contrário, principalmente nas obras Homo Hierarquicus (Dumont, 1997) e O individualismo (Dumont, 1985). Este autor está particularmente interessado em pensar a hierarquia social através de um prisma diferente daquele que a considera como uma simples série de rankings superpostos. Dumont argumenta, assim, que a hierarquia é, em sua essência, uma sequência de englobamentos de diversas categorias identitárias - com a probabilidade, em certas 
situações sociais específicas, de inversão hierárquica daquela ordem de englobamento tradicional e cotidiana.

Deste modo, é possível mapear as relações prováveis entre o mito contado por Roptyktxi e a escolha do termo "goronã" (ou "ngoronã") para dar nome ao núcleo de educação formal da aldeia Kawerêtxikô, a Escola Goronã dos Tapayúna. Há de se notar que esse conhecimento é externo e foi como que englobado ou 'capturado' pelos Kaykwakhratxi de um outro povo, através da guerra e seu espólio.

Prestando maior atenção nos desdobramentos do mito, veremos que a última fase, dos nomes próprios e da festa, não se caracteriza simplesmente pela descoberta da nominação e a apropriação dos nomes. O mais importante é que a etapa final introduz também uma diferenciação mais genérica entre as pessoas: há nomes especiais e nomes comuns. Há ainda uma maneira ritual específica, uma festa determinada para se atribuir os nomes especiais a uma pessoa. Portanto, não se ganha do povo que é belicamente conquistado somente os nomes em si: se apreende, com eles (ou com ao menos um deles), a gerir esses nomes dentro de um sistema ritual hierarquizado. A Escola Goronã, nesse contexto, está intimamente relacionada à conquista do novo, do diferente, do Outro. Essa conquista, como se vê, não é uma simples 'emulação' ou 'adaptação': o que se pretende é apreender a fundo o sistema geral em que essa alteridade opera, e não apenas copiá-la de maneira rudimentar. Os Tapayúna, assim, ritualmente englobam um outro povo, que, apesar de fisicamente exterminado, continua existindo nas festas de nominação Kaykwakhratxi.

Todavia, é impossível não ceder ao fato de que a apropriação e o diversos usos que fazem essas populações dos produtos materiais e técnicas não-indígenas teve que se dar de maneira parcialmente diferente daquela que tradicionalmente era feita. Os não-indígenas, em vez de vencidos de guerra, são justamente aqueles que sedentarizaram os Jê em áreas geográficas não-tradicionais (caso dos Tapayúna e dos Xikrin) ou limitaram sobremaneira o trânsito das pessoas dentro de seu próprio território tradicional (como os Mebengôkrê da Terra Indígena Capoto Jarinã). Isso quando não foi o caso do genocídio completo de populações inteiras, das quais não temos, atualmente, muito mais informações do que a referência ao nome de como eram conhecidos na época.

Os não-indígenas, dentro do contexto Tapayúna, são, assim, um caso de englobamento de uma nova alteridade que acaba por rever ou ameaçar, parcialmente, 
a própria maneira como o englobamento ou a apropriação do novo se dá. Como bem aponta Cesar Gordon (op. cit.), há sempre, no contato com os não-indígenas, a potencialidade de se estar aproximando demais da alteridade e deixando de ser, de maneira não-controlada, aquilo que se era. Como já argumentava Bruce Albert na introdução da coletânea Pacificando o branco, o grau de violência no contato com os não-indígenas é sem precedentes (Albert, 2002). Penso que a etnografia da Escola Goronã ajudará a matizar melhor essas questões.

\subsection{A Escola Goronã de Kawerêtxikô: uma instituição tapayúna}

A Escola Goronã, durante meu período de trabalho de campo, ocupou dois espaços geográficos diferentes, ambos fora do círculo da aldeia. Adianto que a maioria quase absoluta das aulas que pude etnografar aconteceram na antiga estrutura (Imagem 01), atualmente em desuso.

Inicialmente, os alunos e professores se reuniam em uma construção bastante similar ao resto das casas de Kawerêtxikô: uma estrutura de grossas toras de madeira, coberta com folhas secas de bananeira brava. A única peculiaridade dessa construção era que ela, ao contrário das casas, não possuía as paredes laterais dessas últimas (Imagem 01). Tais paredes são comumente feitas de troncos de uma madeira mais fina que aquelas que constituem a estrutura da casa ${ }^{60}$. Esses troncos finos são arranjados lado-a-lado e impedem, assim, a entrada de animais maiores, como os cachorros, que só adentram as residências pela única porta da mesma, virada para o centro da aldeia. Contudo, é possível ver, no vão entre os troncos, boa parte do que acontece dentro da casa. Essas paredes externas, contudo, garantem algum tipo de privacidade: quando de dia, alguém de fora consegue ver que há outras pessoas dentro da casa, mas a diferença de luminosidade não deixa saber exatamente o que elas estão fazendo lá dentro. Esse cercamento não impede a entrada de animais menores, como as galinhas, insetos, cobras, entre outros.

\footnotetext{
${ }^{60}$ Há apenas duas casas em que o cercamento é feito por tábuas compradas nas cidades da região: a do cacique Roptyktxi e a de uma de suas filhas, casada com um homem mebengôkrê.
} 
Essa antiga construção da Escola ainda está de pé, mas não recebe atualmente mais aulas (Imagem 01). Ela está, como também uma antiga estrutura do posto-desaúde, sem qualquer uso específico e é, nos dias de hoje, lugar de brincadeiras de crianças ou, por vezes, abrigo temporário de algum transeunte que sobe o barranco do rio Xingu e para procurar abrigo da chuva, por exemplo.

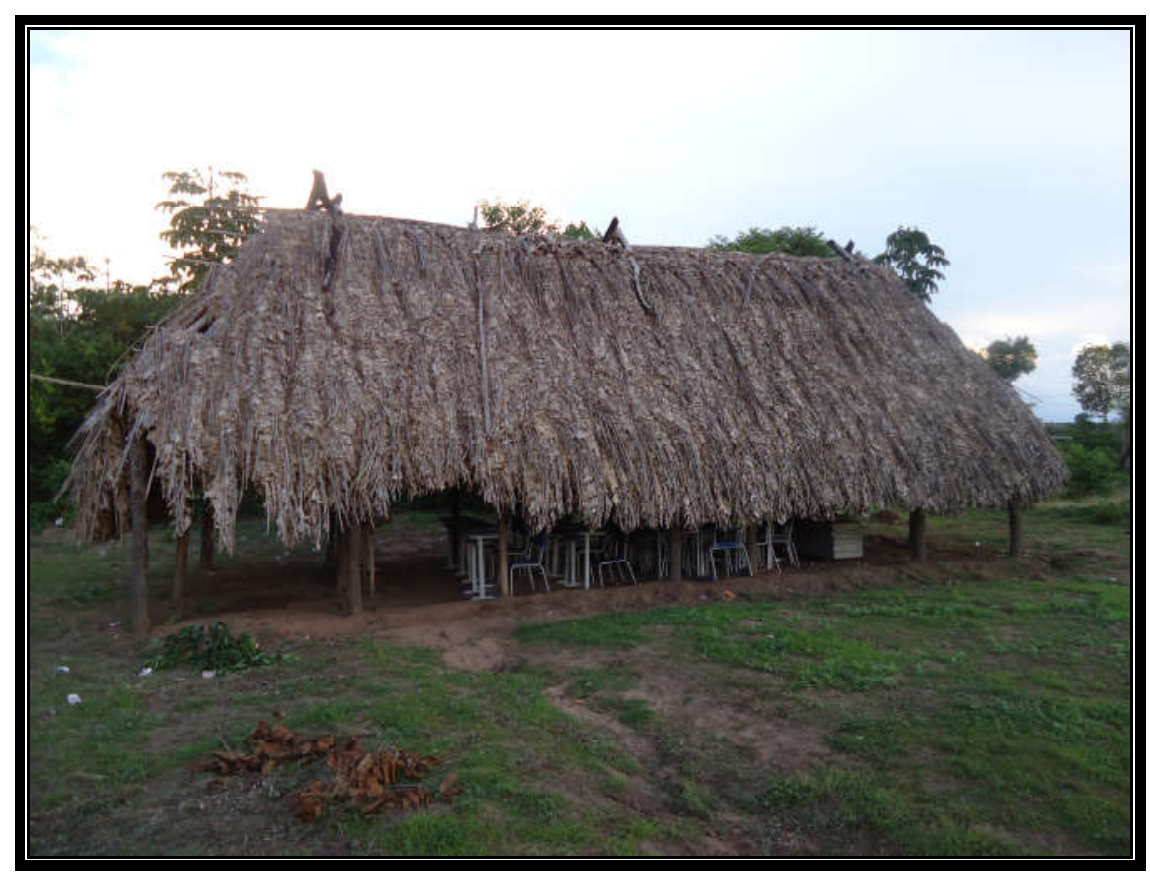

Imagem 01: Estrutura da Escola Goronã. Note-se a falta de paredes laterais, o que torna possível enxergar parte das carteiras da sala de aula. O quadro-negro, de giz, ficava do lado esquerdo da fotografia, de frente para as carteiras. Este último foi retirado e levado, junto com parte do material didático, para uma nova estrutura no final do ano de 2015.

A nova estrutura, como a antiga, foi totalmente montada por homens de Kawerêtxikô. Ela foi feita nos últimos meses do ano de 2015, nos derradeiros meses do meu trabalho de campo. Ela difere um pouco da primeira estrutura. Assim, em vez de telhas de palha trançada de bananeira brava, há então telhas industrializadas de amianto, fixadas com chaves de fenda, parafusos e porcas, nas partes centrais, e com martelo e pregos, nas partes adjacentes. A construção, apesar de também feita com troncos retirados da mata da região, teve alguns desses troncos cerrados e endireitados com a ajuda de uma moto-serra; a área coberta é maior que a anterior, abrigando o espaço de duas salas de aula, com dois quadros-negros, enquanto a primeira (Imagem 01) tinha apenas uma única sala. Contudo, na nova construção não há divisão alguma entre as salas, do mesmo modo que não há divisões laterais da estrutura coberta para o 
lado de fora, como na antiga construção. Os Tapayúna conseguiram dinheiro para essa nova estrutura a partir de uma verba emergencial do Governo Federal para escolas públicas. Eles próprios compraram o material de construção, organizaram-se para trazê-lo à Kawerêtxikô, montaram a estrutura e fizeram, por fim, a prestação de contas.

No que se refere às construções em geral dos Tapayúna, é preciso dizer que as paredes laterais em volta da casa são itens secundários, feitos a posteriori. Como vimos, a antiga Escola Goronã nunca teve e a nova também não. Para dar outro exemplo, Horengô Tapayúna, sobrinho de Orengô, se mudou para uma casa nova a partir do momento em que sua esposa deu a luz ao primeiro filho. Depois do telhado coberto com folhas de bananeira brava com a ajuda de outros jovens, ele não esperou a feitura das paredes laterais para se mudar. Ele improvisou essas últimas com lonas e tecidos. Horengô gradativamente construiu, depois de se mudar, as paredes com ripas de madeira fina, lado-a-lado, no estilo tradicional das casas de Kawerêtxikô. Os panos e lonas foram, então, substituídos. O mesmo aconteceu na construção da casa nova de Kokokaron, homem mebengôkrê casado com uma das filhas do cacique Roptyktxi: sua casa foi ocupada logo depois que o teto foi terminado, com a ajuda de outros homens. É importante notar que as casas de Horengô e Kokokaron foram construídas pelos jovens homens da aldeia, como o posto-de-saúde e a Escola, todas em um sistema que um não-indígena chamaria genericamente de 'mutirão'. É claro que tal termo é uma simplificação e que, possivelmente, há relações de parentesco diversas perpassando esse sistema de ajuda mútua, relações que ainda não pude etnografar com maiores detalhes. Apesar de não ter acompanhado a construção inicial de Kawerêtxikô a partir do ano de 2006, me foi dito que todas as construções da aldeia tiveram essa mesma origem.

Assim, explico da seguinte maneira a falta das paredes laterais na Escola Goronã: nela, não reside ninguém de maneira relativamente permanente. Enquanto a farmácia, como veremos, é um local de moradia temporário, com paredes laterais feitas ao estilo das outras casas dentro do círculo de Kawerêtxikô, a Escola é um local de passagem e, portanto, não precisa das mesmas paredes.

Como já dito, acompanhei, na verdade, poucas aulas na nova estrutura física da Escola Goronã. Ela foi construída no fim do período letivo e começo das férias escolares, alguns meses antes do fim do meu trabalho de campo. Deste modo, quando 
estiver me referindo à estrutura física ou local de aulas da Escola Goronã, salvo ressalva específica, estarei fazendo referência à construção mostrada na Imagem $01^{61}$.

Sobre a Escola Goronã, recolhi diversas narrativas de como e porque ela foi criada. Irei me focar aqui na fala dos três jovens de Kawerêtxikô já citados. Eles, durante meu campo, estavam diretamente relacionados à educação formal na aldeia: Txuakrê Metyktire, então diretor da Escola; Orengô Tapayúna, então professor e coordenador dos professores; e, por fim, Wengroi Tapayúna, atual diretor (substituindo Txuakrê) e, na época, professor. As três narrativas convergem em diversos pontos: inicialmente, há a descrição de um alívio generalizado por não se precisar encaminhar mais as crianças ou adolescentes à cidade para que eles fizessem os primeiros anos do ensino formal. Era essa a situação antes da fundação da aldeia Kawerêtxikô e, ainda mais, antes da construção de uma escola em Piaraçu e no Metyktire, quando os Tapayúna lá residiam, como descrito no capítulo anterior. Nessa época anterior, eles e outros indígenas precisavam ir para as cidades do entorno para estudar o ensino formal.

Os três homens mencionados estudaram por períodos distintos em escolas nas cidades da região e todos possuem uma avaliação geral extremamente negativa dessa experiência. Txuakrê passou fome pois não tinha ajuda de sua família extensa na produção de alimentos, por exemplo:

Estudar na cidade foi sempre bem difícil. Eu morava lá naquela aldeiazinha na entrada da cidade [de São José do Xingu, extremo norte do Mato Grosso]. Acho que na época tinha lá um pessoal Suyá e Juruna, morando lá. $\mathrm{Na}$ época era ruim, tinha vez que não tinha nem mesmo o de comer porque a gente tava longe da família, longe dos parentes. Bem difícil.

\footnotetext{
${ }^{61}$ No fim de mês de maio de 2016, enquanto trabalhava na escrita do presente capítulo, recebi uma mensagem por correio eletrônico da antropóloga Daniela Batista de Lima. Ela me informou que, durante os últimos meses em que ela esteve em Kawerêtxikô, havia sido construída uma nova estrutura física da Escola, de alvenaria. Essa estrutura foi custeada pela Seduc-MT, tanto o material de construção, como também os trabalhadores, todos não-indígenas. Pude acompanhar um tipo parecido de implemento enquanto assessorava o curso de Maria Eliza Leite no ano de 2012 (cf. Introdução). Se a construção dessa escola de alvenaria dos Tapayúna seguiu os mesmos moldes que a construída em Piaraçu em 2012, então os trabalhadores não-indígenas passavam a semana trabalhando na construção da escola e, nos fins de semana, voltavam para suas casas nos municípios da região. O contato deles com os indígenas era ínfimo e as conversas e relações em geral se davam entre indígenas, de um lado, e não-indígenas, de outro - completamente apartados uns dos outros, pelo que pude notar, inclusive as refeições, as quais os operários não-indígenas faziam com um rancho especialmente trazido para eles.
} 
Note-se que ele residia em uma comunidade perto da cidade que não era uma comunidade Mebengôkrê e, pela falta de apoio, foi obrigado a voltar para a aldeia sem ter completado seus estudos básicos. Dessa passagem, pode-se depreender, ainda, a centralidade dos laços de parentesco: sem os mesmos, até a alimentação básica fíca restringida.

Orengô disse que, na cidade, fazia uso de bebidas alcoólicas constantemente e que os conflitos com os estudantes não-indígenas eram corriqueiros. Devido a esses problemas, ele argumenta então que "minha família me buscou, tive que voltar. Tava arrumando muita confusão e bebia todo dia [risos].” A família extensa de Orengô o trouxe de volta e ele só continuou os estudos formais depois que foram construídas escolas dentro da Terra Indígena Capoto Jarinã.

Neste interregno, Orengô fazia parte de um grupo que cuidava da segurança das fronteiras da TI Capoto Jarinã, junto com outros povos, em sua maioria Mebengôkrê. Contudo, depois de alguns confrontos com não-indígenas que invadiam (e ainda hoje invadem) a TI ilegalmente para retirar madeira, pescar ou tentar grilar porções de terra nas fronteiras da Terra Indígena, Orengô desistiu desse trabalho e começou a investir no ensino formal. Ele diz ter feito isso para livrar sua mãe de se preocupar cotidianamente com ele: ela ficara sabendo de uma última refrega entre os indígenas que faziam a segurança das fronteiras da TI Capoto Jarinã e não-indígenas invasores. Nessa ocasião, o irmão de Txuakrê, amigo de Orengô, teve seu barco de alumínio furado a balas de arma de fogo. Como os não-indígenas estavam fortemente armados, os indígenas foram obrigados a pedir ajuda do Exército brasileiro. Orengô e Txuakrê me contaram esse caso com fascínio e admiração: eles nunca haviam visto um helicóptero do Exército e menos ainda soldados fortemente armados que prenderam e retiraram os invasores naquela ocasião. Os barcos, motores de popa, telhas de alumínio e o material em geral deixado pelos invasores foi divido como espólio de guerra entre os indígenas que faziam a segurança das fronteiras da TI. De todo modo, a mãe de Orengô o convenceu a mudar de área e começar a estudar para ser professor indígena, ocupação que, para ela, era menos perigosa que a anterior.

Wengroi foi companheiro de Orengô na mesma época em que o último estudava na cidade e corrobora sua narrativa. Ele acrescenta, ainda, que se sente aliviado por seus filhos não precisarem, atualmente, passar por tais privações e 
conflitos. Assim, a opinião geral é de que o ensino formal, dentro das aldeias, foi vantajoso quando em comparação à situação vivida anteriormente, de mudança obrigatória para a cidade entre aqueles que optaram por se versar no ensino formal não-indígena.

A cidade, fora a questão da educação formal, possui uma avaliação ambígua na fala dos homens de Kawerêtxikô. Ao mesmo tempo em que é o espaço onde se adquire os produtos materiais já comuns na vida dos moradores, como comidas e bebidas industrializadas, baterias, placas de energia solar, televisões, antenas parabólicas, celulares, barcos de alumínio, motores de popa, ferramentas em geral, é também onde os Tapayúna experienciam situações extremamente agonísticas. Por exemplo, um dos filhos de Wotkàtxi Tapayúna não pisa mais em nenhuma cidade da região depois de ter passado cerca de dois dias na cadeia da delegacia policial de uma delas.

Outros jovens contam esse caso de maneira jocosa e, ao mesmo tempo, orgulhosa, pois eles conseguiram efetivamente enfrentar os desafios impostos pelo meio urbano. Ao contrário deles, o filho de Wotkàtxi não foi convencido a ir para a cidade nem mesmo para acompanhar seu pai, que estava, em certa ocasião, bastante doente e não falava bem o Português. A pilhéria generalizada teve como base o medo desse jovem de ser aprisionado de novo e o fato dele não conhecer o sistema punitivo dos não-indígenas. Assim, mesmo com seus pares lhe garantindo que ele não seria preso de novo pelo "crime que já pagou", ele não voltou a freqüentar as cidades. Seu 'crime' foi jogar, embriagado, uma pedra em um carro que quase havia the atropelado enquanto atravessava uma rua. Isto lhe valeu, sem julgamento, os malfazejos dias na cadeia da delegacia.

A cidade é também, para os homens, o espaço para aventuras amorosas rápidas com mulheres indígenas e não-indígenas que não a esposa oficial. Esses encontros são chamados por todos os indígenas que tive contato, não importando a etnia, de "namoro" - sendo o mesmo pago com dinheiro ou não. A cidade de Peixoto de Azevedo, por exemplo, possui diversos lupanares, tanto na zona urbana como também nas imediações rurais da cidade.

Os centros urbanos são também conhecidos pela violência descontrolada que paira sobre eles. Por exemplo, como mostrei no capítulo 2, os indígenas apelidaram a cidade de São José do Xingu-MT, a mais próxima à Terra Indígena Capoto Jarinã, de 
'Bangue', em referência ao bang-bang do Velho Oeste estadunidense. Nessa cidade, segundo eles, é comum ver não-indígenas bêbados, armados com armas de fogo ou armas brancas e que podem matar alguém sem nenhum motivo aparente.

A estrutura física mostrada na Imagem 01 não era ideal para se guardar, por exemplo, papel, giz ou outros materiais didáticos: apesar do telhado ter sido bem feito e não pingar uma gota dentro da sala no período das chuvas, ele deixava passar muita umidade. Este fator rapidamente deteriorava o papel guardado nas prateleiras próximas ao teto (Imagem 02).

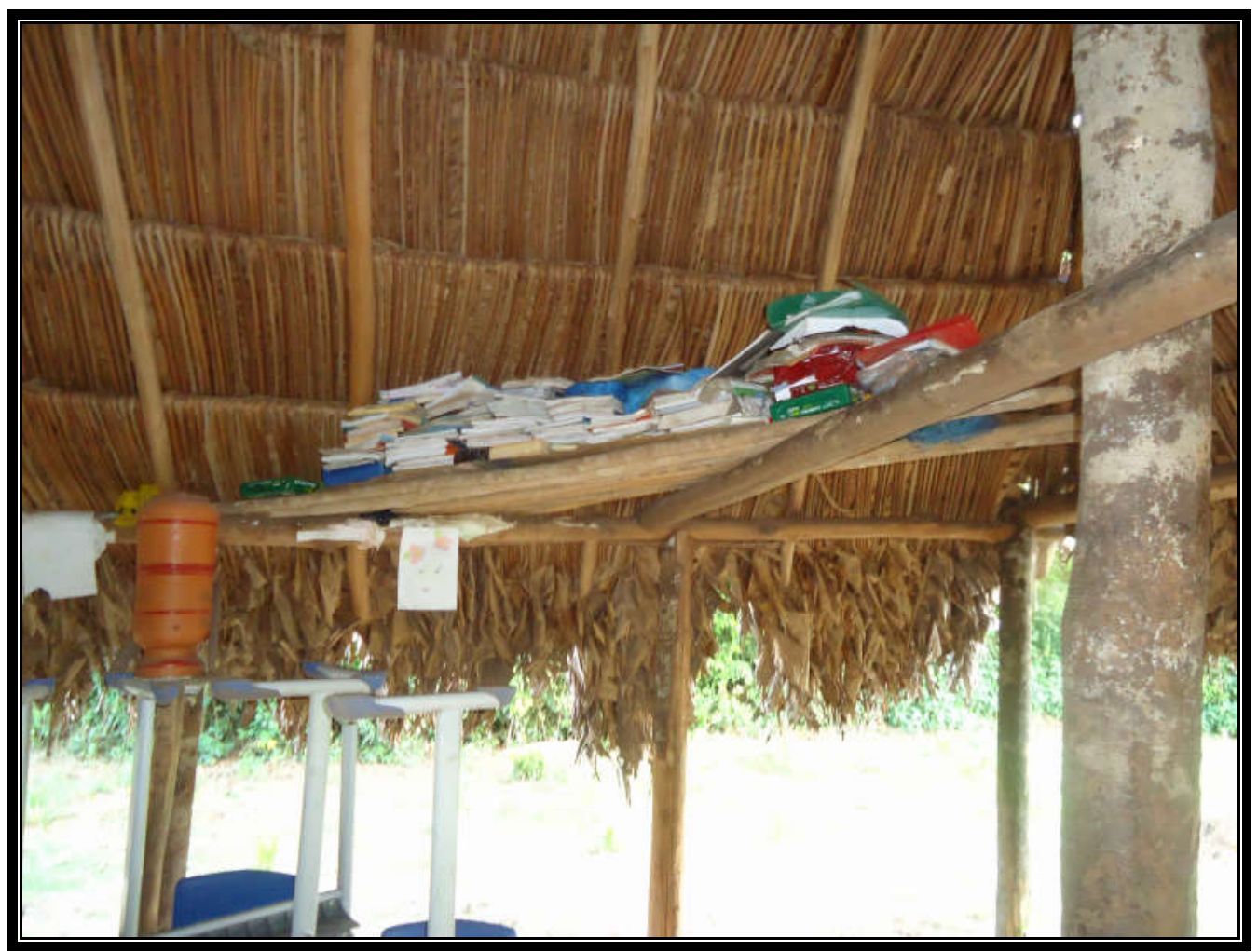

Imagem 02: Material didático guardado em prateleira improvisadas dentro da estrutura da Escola Goronã. Especialmente os papéis sofrem com a alta umidade do local, já que estão no alto da construção, próximos ao teto de palha. Há desenhos dos alunos mais novos, como os da imagem, pendurados em toda a estrutura da Escola Goronã.

No que tange aos funcionários da Escola Goronã, o diretor e o coordenador pedagógico da Escola Goronã eram aqueles que viajavam mais frequentemente, representando os Tapayúna, para a cidade de Peixoto de Azevedo, acompanhando as reuniões na sede da Secretaria de Educação nesse centro urbano e retransmitindo as informações para os residentes de Kawerêtxikô. Narrarei uma dessas viagens na conclusão da presente tese. Eles também gerenciavam os recursos repassados, como o da merenda escolar, por exemplo, e, em conjunto com os professores e as lideranças, 
como o cacique Roptyktxi e o wajanga $^{62}$ Wotkàtxi, preparavam o ano letivo e o Plano Político e Pedagógico (PPP) da Escola Goronã. No que tange à merenda escolar, ela era distribuída para as famílias pelo merendeiro e cada aluno fazia sua refeição em casa, já que não havia refeitório na estrutura da Escola. Comprava-se, normalmente, bolachas, biscoitos e outros produtos industrializados, pois precisava-se prestar conta com notas fiscais da merenda comprada e os produtos advindos das roças, caças, pescas e criação da aldeia não cumpriam essa obrigação.

Além dos professores, outros indígenas também eram, por vezes, responsáveis pelas aulas. Assim, dois jovens kinsedje recém-chegados da Terra Indígena Wawi foram contratados como espécie de estagiários, não recebendo um salário em si, mas sendo pagos com cheques da Escola Goronã. Esses contratados ficaram responsáveis por algumas aulas de Kaykwakhratxi, já que a língua dos Kinsedje é bastante próxima à dos Tapayúna e os dois falavam fluentemente as duas. Além disso, nos fins de semana, eles ajudavam os estudantes em aulas de como montar e cuidar de hortas, principalmente de produtos introduzidos por não-indígenas, como a cana-de-açúcar, o mamão ou o abacaxi.

Não é difícil perceber, em Kawerêtxikô, que aqueles que estão diretamente ligados à Escola Goronã compartilham certas características em comum. Por exemplo, todos eles são jovens homens indígenas com conhecimento razoável do Português. Todos são, em graus diferentes, alfabetizados nessa língua. Assim, ainda que as aulas não se dêem nessa última língua, professores e outros funcionários precisam ter algum domínio dela, já que terão que visitar a cidade, abrir uma conta no banco, receber salários, fazer compras, fazer os planos de aula em Português e, por fim, negociar e pagar um freteiro não-indígena para levar os produtos comprados com o salário até a balsa de Piaraçu, como já descrito no capítulo 2 .

Com isso, todos os diretamente envolvidos na Escola Goronã dominam relativamente bem o Português, o Mebengôkrê e, por vezes, o Kaykwakhratxi. Por vezes, já que há vários funcionários da Escola, como o então diretor Txuakrê Metyktire ou o professor Kokokaron (substituto ocasional de Orengô) que, apesar de

\footnotetext{
${ }^{62}$ Essa é a palavra em Kaykwakhratxi para a função de pajé. Para uma análise dos wajanga tapayúna, conferir Batista de Lima, 2012. Segundo essa autora, o papel de contato com os brancos foi iniciado por um famoso xamã tapayúna, que foi o primeiro a conseguir domesticar, com seus poderes especiais, um grupo de não-indígenas. Por vezes, Wotkàtxi era chamado para algumas aulas na Escola Goronã, contando um mito específico ou, então, ensinando alguma técnica de artesanato aos alunos. Contudo, ele nunca participou oficialmente do staff da Escola. Deixo para a conclusão a comparação entre o ofício de wajanga e o ensino formal.
} 
casados com mulheres tapayúna, não tiveram o Kaykwakhratxi como língua materna, mas sim o Mebengôkrê. Eles entendem essa primeira língua perfeitamente, mas, na maioria das vezes, não se sentem à vontade para fazer discursos nela, principalmente quando há um interlocutor tapayúna presente. É esse o caso, por exemplo, do ancião Watyia citado no capítulo anterior. Watyia, Txuakrê, Kokokaron, entre outros, ensinaram como primeira língua de seus filhos e filhas o Mebengôkrê, idioma franco da região.

Algumas aulas da Escola Goronã acontecem, então, em Mebengôkrê, outras em Kaykwakhratxi - e, mais ainda, outras aulas são sobre como falar e escrever em Kaykwakhratxi. Essas últimas aulas visam alfabetizar e tornar os alunos aptos a falar Kaykwakhratxi, principalmente aqueles que são filhos de casamento com um cônjuge Mebêngôkrê - o que perfaz a maioria das crianças da aldeia.

Portanto, os Tapayúna tentam, em certo sentido, usar a educação formal para 'tapaiunizar' os falantes de Mebengôkrê residentes em Kawerêtxikô. De toda forma, o não-domínio completo do Kaykwakhratxi não é impedimento para se ocupar cargos na Escola Goronã, como o exemplo do ex-diretor Txuakrê Metyktire ou do atual professor Bepkôrô deixam entrever. Somente nos últimos anos de ensino, os mais avançados, é que os estudantes possuem contato, formalmente, com o Português, em aulas em Mebengôkrê ou Kaykwakhratxi ensinando essa língua não-indígena.

Esse contato formal, é claro, é precedido por relações não-formais. Vários jovens, principalmente os do sexo masculino, acompanham seus pais ou, por vezes, avós nas idas às cidades, desde muito cedo, com três ou quatro anos. Além disso, todos os estudantes, homens ou mulheres, já passaram por algum atendimento com um funcionário não-indígena, seja na farmácia de Kawerêtxikô, seja em hospitais ou Casas de Saúde Indígena (Casais) da região, como deixarei claro no capítulo 4. Principalmente fora da região Capoto Jarinã, o Português é língua franca - ao menos nos contatos com os não-indígenas. As crianças também visitam diariamente as casas dos Tapayúna que possuem TV e parabólica para assistir principalmente os desenhos, todos dublados em Português. Para dar um exemplo, o filho mais velho de Orengô, Okete Tapayúna, com treze anos, já fala, entende e escreve relativamente bem o Português. Ele estuda as últimas séries na Escola Goronã e nos próximos anos irá estudar o ensino médio em Piaraçu. 
Esboça-se, portanto, um ensino tri-língue em Kawerêtxikô: as crianças são ensinadas a falar Kaykwakhratxi e Mebêngôkrê antes mesmo de irem à Escola Goronã; depois disso, são normalmente alfabetizadas também nessas duas línguas, nas séries inicias; antes de cursar o ensino médio na aldeia mebengôkrê de Piaraçu, aprendem a ser fluentes no Português e, ao mesmo tempo, nos cálculos matemáticos básicos. Também são ensinadas noções de história não-indígena, higiene e biologia evolutiva ainda na aldeia dos Tapayúna. Por fim, as aulas de educação física (vôlei, futebol e outros jogos, como o cabo-de-guerra ou peteca) se dão nas imediações do centro limpo da aldeia, fora da estrutura da Escola Goronã.

Dado esse contexto da educação formal entre os Tapayúna, não há como negar que os empregos e o prestígio gerados por se ter uma escola independente foram todos capitaneados em favor daqueles residentes nessa última localidade. Como nos casos descritos e analisados por Luciano (2011) e Benites (2009) e já discutidos no capítulo 1, os Tapayúna agenciaram a Escola Goronã como parte das relações interétnicas dentro de um contexto político regional bastante específico: aquele da Terra Indígena Capoto Jarinã. Nessa conjuntura, os 'rivais' ou 'concorrentes' por excelência são os Mebengôkrê, mais pontualmente aqueles residentes fora da aldeia Kawerêtxikô. O terceiro 'mediador' ou 'árbitro', para qual os interesses dos Tapayúna e dos Mebengôkrê convergem, são os não-indígenas que fazem parte, em algum grau, da estrutura burocrático-administrativa da educação formal dentro dos diversos níveis do funcionalismo público do Estado brasileiro. Assim, se Kawerêtxikô não tivesse sido fundada, nem tão pouco a Escola Goronã, o que aconteceria é que os Mebengôkrê da aldeia do Metyktire seriam fortalecidos com um número populacional maior - espécie de 'moeda de barganha' para a construção de postos-de-saúde e escolas públicas pelos Estado brasileiro - e, além disso, os professores indígenas trariam a renda de seus salários para uma aldeia que, ao menos em certo nível identitário, é uma aldeia dos Mebengôkrê - e não dos Kaykwakhratxi.

Assim, nesse contexto mais geral em que a aldeia Kawerêtxikô está inserida, uma chave interpretativa possível são os trabalhos do sociólogo Georg Simmel sobre a tríade que pode ser formada em uma situação conflituosa específica (Simmel, 1950). Não é raro, na literatura de conquista e de colonização dos mais diversos povos, a descrição de situações similares a essa, com os ocidentais ou não-indígenas se arvorando ou mesmo forçando uma arbitragem em conflitos que, por vezes, eles 
próprios são os responsáveis ou co-responsáveis pela origem. De todo modo, relembro aqui que minha preocupação mais direta, nesse momento, é fazer uma análise e descrição das relações internas dos residentes da aldeia Kawerêtxikô no tocante à educação formal.

\subsection{Uma etnografia das aulas na Escola Goronã}

Darei aqui três exemplos de aulas que tive a oportunidade de acompanhar na Escola Goronã: as dos professores Wengroi, de Bepkôrô e, por fim, de Nokêrê. Como são, ao todo, quatro professores regularmente contratados lecionando em Kawerêtxikô, tal análise cobre a maioria das aulas. Deixo de lado as aulas do professor Orengô, adiantando, de todo modo, que as mesmas eram bastante próximas à descrição que farei das aulas de Wengroi. Passo a fazer, assim, uma breve introdução dessas três figuras.

Nokêrê era uma liderança política de Kawerêtxikô e o professor mais velho a dar aulas regularmente, com aproximadamente cerca de 55-60 anos. Ele sempre acompanhava as discussões na Casa dos Homens e era um dos grandes apoiadores do cacique Ropyktxi. Casado com uma das irmãs de Roptyktxi, Nokêrê era quase sempre o primeiro homem a chegar nas reuniões diárias da Casa dos Homens e um dos que mais falava nessas reuniões. Já Bepkôrô era o mais novo dos três. Seu nome era um nome especial em Mebêngôkrê e ele dava as primeiras aulas do dia em Kawerêtxikô, entre 7:30 e 9:30 da manhã, para as crianças mais novas que estavam sendo alfabetizadas. Ele ainda não havia terminado o curso de magistério indígena em Piaraçu, mas já dava aulas desde 2013; tinha cerca de 20-25 anos. Finalizando essa breve descrição, Wengroi, como já dito, era professor e mais tarde passou a ser diretor da Escola Goronã, tendo por volta de 30-35 anos.. Na época em que tomei a maioria das minhas notas de campo, ele estava terminando sua graduação em Licenciatura Indígena pela Universidade Estadual do Mato Grosso (Unemat) e seria o primeiro morador de Kawerêtxikô com curso superior. Junto com Orengô, Wengroi foi um dos principais informantes da linguista Nayara Camargo, tanto na feitura de sua dissertação de mestrado (Camargo, 2010) como também na de doutorado (Camargo, 
2015). Relembro aqui a situação descrita nos estudos de Tonico Benites e Gersem Luciano: ele próprios foram tradutores e informantes de linguistas e antropólogos, antes de escreverem suas dissertação de mestrado e tese de doutorado sobre a educação formal entre os Avá-Kaiowá e os Baniwa, respectivamente.

Enquanto Nokêrê dava aulas para os anos mais avançados e estudantes mais velhos, Wengroi ficava com uma turma de alunos intermediários, adolescentes e préadolescentes. Todos os três falavam bem o Português e o Mebengôkrê; Wengroi e Nokêrê tiveram o Kaykwakhratxi como língua materna, o que não se aplica ao mebengôkrê Bepkôrô.

A sequência das aulas durante um dia comum era a seguinte: inicialmente, Bepkôrô dava aulas para os estudantes mais jovens, as crianças, pela manhã; depois, na segunda parte da manhã, vinha Wengroi com uma turma de alunos um pouco mais velha, entre 10 e 15 anos. Depois do almoço, no primeiro período da tarde, aconteciam as aulas de Nokêrê, com estudantes, em sua maioria, adultos. Na primeira turma, havia tanto alunos do sexo masculino como feminino; já na intermediária, a maioria, ainda que não em grande número, era do sexo feminino; na última, a maioria era de homens.

Sigo a ordem cronológica e inicio a descrição com as aulas de Bepkôrô. Às 7:30 da manhã, todos já estavam acordados há algumas horas em Kawerêtxikô. Os primeiros a se levantar deixavam suas redes ou camas pouco antes do nascer do sol. Com o dia claro, praticamente toda a aldeia estava de pé, inclusive as crianças - e isso se dava por volta das 6:00. Quando residia na casa de Orengô, eu podia ver Bepkôrô saindo de sua casa e se dirigindo à Escola Goronã. Ele se encontrava com outras pessoas que estavam indo também para fora do círculo de Kawerêtxikô, mas no intuito de tomar o primeiro banho do dia no rio Xingu. Depois que mudei para a farmácia, esperava ele e as crianças já na sala de aula, que ficava ao lado do posto-desaúde. Bepkôrô chegava, na maioria das vezes, um pouco antes delas.

Nas primeiras aulas que pude acompanhar desse professor, ele alfabetizava as crianças em Kaykwakhratxi. Os estudantes se sentavam, um ao lado dos outros, nas cadeiras e carteiras de frente ao quadro de giz. O professor ficava na frente da sala, do lado do quadro, em um carteira/cadeira igual a dos alunos, diante deles. Bepkôrô, com letra de forma, escrevia no quadro o nome da Escola ("Escola Goronã") e a data da aula, seguindo o calendário não-indígena (“27/03/14”). 
A aula do dia 27 se iniciou com o professor escrevendo no quadro, também em letra de forma, a palavra kaykwakhratxi "Wewe". Depois disso, ele gastou algum tempo desenhando uma grande borboleta, junto à palavra. Os alunos, então, foram instados pelo docente a desenhar, cada um, sua própria borboleta ou "Wewe". Pude notar que Bepkôrô seguia uma das atividades de alfabetização trabalhadas no curso de formação de professores da Funai, organizado por Maria Eliza (cf. Introdução). Contudo, as crianças não tinham, ainda, uma apostilha impressa com as atividades de alfabetização. Cada aluno escrevia "wewe" em seu caderno e fazia o desenho. Isso tomava algum tempo e, os que iam gradativamente terminando a atividade, levavamna para o professor dar um visto na mesa desse último, que permanecia sentado enquanto os alunos trabalhavam.

Pouco antes dos vistos, a pedido do docente, uma da alunas agilmente subiria em um dos pilares de sustentação da estrutura da Escola para pegar lápis de cor nas altas prateleiras da construção (Imagem 02). Logo um outro aluno também subiu para ajudar a primeira estudante. Eles desceram com grande quantidade de lápis de cor e os distribuíram para que os outros e eles próprios pudessem colorir suas borboletas.

Finda essa atividade, Bepkôrô iniciou uma outra: agora os estudantes precisavam decifrar um espécie de diagrama. O docente escreveu um esquema no quadro, com várias seqüências de triângulos, círculos e quadrados, entre outras formas geométricas. Depois dos alunos copiarem, ele deu a chave para interpretação do diagrama, em que cada forma geométrica correspondia a uma letra do alfabeto kaykwakhratxi. As crianças iam, assim, formando palavras nessa língua na medida em que iam decifrando o diagrama. Nesse momento, nos aproximávamos das 9:30, horário do fim da aula. Quando o professor anunciou o fim, as crianças partiram em disparada, todas juntas, de volta para o círculo de Kawerêtxikô. Durante todo o tempo da aula, eu fiquei sentado em uma carteira na última fileira da sala. Por vezes, alguns estudantes olhavam para trás, curiosos com a minha presença na aula, principalmente os do sexo masculino. As meninas eram visivelmente mais acanhadas e só raramente cruzavam o olhar comigo.

Deste modo, por mais que eu tentasse, em nenhuma aula que acompanhei pude evitar de ser notado. Tive a impressão geral de que era visto, principalmente pelos professores, como um "especialista" em Português e outros temas não-indígenas - ou em ensino formal, genericamente falando. Por exemplo, dei várias aulas de Inglês, 
uma língua que mais ninguém na aldeia conhecia. Ao mesmo tempo ajudei, em inúmeras ocasiões, os caciques e as lideranças a fazer textos em Português, como o já citado PPP, ou pedidos de mercadorias e serviços para instituições não-indígenas como a Funai ou as prefeituras da região - ou, por vezes, também para o Instituto Raoni. Outra vezes, ajudava na feitura ou revisava, junto com os professores, os planos de aula, trabalhos de faculdade (no caso de Wengroi) e quaisquer outros documentos que precisassem ser escritos em Português, como os relatórios que os professores tinham que entregar para a Secretaria de Educação sobre suas aulas. Quando algum professor que dava aulas de Português, como Nokêrê, tinha alguma uma dúvida, ele vinha diretamente a mim ou a alguma funcionária não-indígena do posto-de-saúde. Enfim, eu era o "especialista" em assuntos como esses que descrevi, que envolviam escrita em Português de textos para autoridades e instituições nãoindígenas e, por vezes, também indígenas ${ }^{63}$.

Certo dia, Txuakrê me pediu para dar uma explicação de biologia evolutiva a um grupo de homens que, como eu, o visitava em sua casa. Tentei relembrar de minhas aulas de ensino médio e fiz o possível para explicar esquematicamente a teoria de Darwin para esses jovens Tapayúna. Cito esse caso pois a repercussão dessa aula específica foi bastante interessante: um dia depois, em uma conversa em Português com alguns desses jovens na Casa dos Homens, um outro homem tapayúna voltava de uma caçada bem sucedida, carregando um grande macaco nas costas. Txuakrê, sempre muito bem humorado, comentou algo em Português que fez todos os presentes terem uma crise de riso. Ele me perguntou se eu aprovaria que aquele caçador que levava o macaco morto comesse um dos meus "parentes", fazendo referência explícita à teoria evolucionista dos não-indígenas que consideram os primatas como antecessores pré-históricos dos humanos.

A minha impressão geral das aulas dadas pelos indígenas é semelhante à posição de Ingrid Weber (2006) entre os Kaxinawá: o ensino formal, ao menos para as séries iniciais como as que Bepkôrô trabalhava, é mais 'mecânico' ou de repetição e menos reflexivo e auto-consciente do que as aulas para séries mais avançadas. Apesar

\footnotetext{
${ }^{63} \mathrm{O}$ termo "especialista" já havia sido usado antes por Maria Eliza Leite e seu grupo - do qual eu fazia parte - durante seu curso em 2012 (cf. Introdução), tanto por indígenas como por não-indígenas. Contudo, ele era reservado para se referir àqueles indígenas que não eram professores regulares e participariam do curso como apresentadores, a exemplo da liderança mebengôkrê Megaron Txucarramãe, que contou, durante o referido curso, um conjunto de mitos e falou, junto com Bedjai, cacique da aldeia Piaraçu, sobre o parentesco entre os Mebengôkrê. Megaron e Bêdjai eram, então, "especialistas" em Mebengôkrê, apesar de não ocuparem o cargo de professor.
} 
desse mecanicismo, as crianças possuíam uma liberdade que alunos indígenas que estiveram nas cidades não possuíram: elas podiam se levantar quando quisessem, sem pedir licença ou qualquer autorização, e voltar para suas casas ou dar uma volta pelas redondezas, ainda que durante as aulas. Elas eram alfabetizadas numa língua na qual já haviam tido uma ampla vivência prévia, com um material didático trabalhado especialmente para elas e em contato com outras crianças em condições similares. Em última instância, elas podiam estar residindo em Kawerêtxikô e, mesmo sem o consentimento dos pais, não assistir aquela determinada aula. $\mathrm{Na}$ verdade, elas podiam não freqüentar o ensino formal de maneira alguma, desde que sua família extensa concordasse com tal posição. Havia, na aldeia dos Tapayúna, poucas famílias que não encaminhavam seus filhos para a Escola Goronã. Mas é necessário notar que tal possibilidade existia e que era adotada por algumas famílias, ainda que minoritárias.

Até onde pude perceber, não havia qualquer tipo de sanção social para os pais e outros familiares que assim decidissem. Em resumo, a Escola Goronã não se parecia com uma prisão - isso quando comparada com as escolas comuns não-indígenas, espaços cercados de muros, com horários bastante rígidos de entrada, saída e permanência, além de toda uma organização geral e estrutura física que relembram o cárcere. Além disso, diferentemente do que prega a atual legislação do Estado brasileiro, a escolarização formal oferecida em Kawerêtxikô não era obrigatória.

O fato de algumas famílias, ainda que minoritárias, não se interessarem em mandar suas crianças à Escola Goronã deve-se, ao menos em parte, a uma noção compartilhada por todos em Kawerêtxikô de que os índios, mais pontualmente os Tapayúna, se "enfraqueceram", de alguma maneira, depois do contato sistemático com os não-indígenas. Orengô, nas longas conversas em Português que tínhamos em sua casa, sempre me falava de como os Tapayúna, antes do contato regular com os não-indígenas, eram capazes de caçar na floresta durante dias ou até semanas a fio. Esses indígenas caçavam apenas com bordunas e arcos e flechas, sem qualquer tipo de arma de fogo, tecnologia dos não-indígenas atualmente bastante apreciada pelos caçadores Tapayúna, já que facilita sobremaneira a caça. Além disso, esses antepassados de Orengô não usavam, segundo ele, qualquer roupa para proteção, nem mesmo calçados como botas ou botinas de couro, hoje essenciais para qualquer expedição de caça entre os homens de Kawerêtxikô. 
Assim, quando Orengô passava muito tempo na cidade, fazendo algum tratamento de saúde ou acompanhando alguma reunião da Seduc-MT, ele voltava, segundo ele próprio, "mole e cansado". Ele me dizia que precisava recuperar o ritmo da vivência em aldeia que havia perdido ou diminuído por ter passado alguns dias "parado, sem fazer nada" na cidade. Esse ritmo se refere ao cotidiano do trabalho na roça, às expedições de pesca, já que Orengô quase que não se aventurava mais na caça depois que uma cobra havia picado sua perna anos antes.

Deste modo, algumas famílias não mandam regularmente seus filhos para as aulas na Escola Goronã porque não querem que eles se tornem ainda mais parecidos com os não-indígenas: fracos, "moles e cansados" frente a qualquer trabalho físico mais demorado. Uma prova de que eles estavam corretos em tomar tal decisão era a visão que tinham do antropólogo não-indígena em campo: fumante compulsivo, ainda não-completamente acostumado a comer as ricas iguarias como a carne de macaco ou arara, efusivamente se recusando cortar sua própria carne com os dentes do peixecachorra para renovar seu sangue, se cansando muito facilmente em qualquer caminhada mais demorada na floresta, entre outros sinais explícitos de fraqueza. Até as crianças menores conseguiam fazer coisas quase impossíveis para o antropólogo, como subir em uma palmeira e retirar folhas com um facão ou talhar um cabo de machado.

Para um conjunto de etnografias de crianças indígenas e sua maior liberdade de agência quando comparada às crianças não-indígenas, pode-se conferir a coletânea organizada por Aracy Lopes da Silva, Angela Nunes e Ana Vera Lopes (2001a). Sobre a liberdade que as famílias extensas podem possuir para decidir o destino de seus membros, pode-se voltar ao capítulo 1 da presente tese e à análise da dissertação de mestrado de Luís Tonico Benites (op. cit). O que fica claro quando comparamos a situação descrita nos diversos artigos dessa coletânea e no estudo de Benites com a realidade encontrada em Kawerêtxikô é que há uma linha de continuidade entre a potencialidade de agência das famílias extensas e a liberdade geral que possuem as crianças para, por exemplo, freqüentarem ou não freqüentarem as aulas de ensino formal, entre outras atividades. Quando há uma hierarquização muito assimétrica entre tais famílias, sugiro que as possibilidades e escolhas diminuem - e as obrigatoriedades aumentam. 
Bepkôro lecionava não somente aulas de Kaykwakhratxi: ele também era responsável pelo componente de educação física para as mesmas crianças. O professor se reunia, então, com seus estudantes no local e horário comuns das outras aulas. Dividia, a partir daí, os alunos em dois grupos mistos, com meninos e meninas, ocasião em que os discentes se levantavam, iam ao quadro na frente da sala de aula e, com a ajuda de Bepkôrô, escreviam, em letra de forma, seu nome no grupo desejado. Depois dessa separação, todos subiam para o círculo da aldeia e começavam alguma atividade física. Pude acompanhar, por exemplo, uma aula de vôlei nesse contexto.

Alguns estudantes acompanharam o professor e o ajudaram a pegar a bola, a rede e as traves para o jogo de vôlei, que estavam guardadas na casa do então diretor Txuakrê. O campo foi marcado, por alunos e professor, fazendo-se um vinco no chão de terra do centro da aldeia com um pedaço de madeira. Com a rede colocada e o campo delimitado, o jogo começou. Os dois times tinham meninos e meninas e, durante o período da aula, o jogo era mediado por Bepkôrô. Ele marcava os pontos e organizava as partidas. Quando se deu o horário do fim da aula, os alunos e outras crianças continuaram jogando, mas Bepkôrô deixou de mediar as partidas e foi para sua casa.

Era próximo às 10 da manhã e fazia um sol realmente muito forte. $\mathrm{Eu}$ acompanhava o jogo de vôlei da Casa dos Homens, protegido do sol. Aos poucos, enquanto eu observava e tomava notas dos alunos, alguns jovens homens começaram a se sentar no balcão dessa última Casa. Assim, de maneira não-formal e completamente espontânea, começamos um jogo de dominó. Já disse que há reuniões diárias, ao entardecer, na Casa dos Homens. Essas últimas são mais formais e visam, de maneira geral, discutir as questões pertinentes a toda aldeia Kawerêtxikô, como já descrito no capítulo anterior. Delas participam, diretamente, somente os homens adultos. Contudo, no restante do dia, essa construção não ficava vazia: crianças de ambos os sexos se protegiam na sua sombra e lá se distraiam com alguma brincadeira; alguns homens, depois de terminado certo afazer como concertar a cerca de um galinheiro ou limpar uma nova parcela de roçado, podiam igualmente se encontrar lá para jogar baralho ou dominó, combinar uma caçada/pescaria ou, simplesmente, conversar. Não era incomum que já existissem algumas pessoas no centro da aldeia quando a maioria dos homens chegava para as reuniões diárias, normalmente ao se 
findar um jogo de futebol e depois de um último banho no rio Xingu ou nas torneiras recentemente instaladas no lado de fora de cada uma das casas ${ }^{64}$.

Assim, a Casa dos Homens era um lugar para os homens, e não, necessariamente, um lugar exclusivo deles. Alguns chegavam para as reuniões diárias com seus filhos mais novos, de ambos os sexos; outros traziam bebês recém-nascidos que, mais tarde, seriam buscados pela esposa para alimentá-los no peito. Ninguém, em uma ocasião como esta, se mostrava importunado por uma mulher adentrar à Casa durante uma reunião formal, nem tão pouco pelo choro do bebê.

Ao contrário de Nokêrê e Wengroi, que são mais velhos, Bepkôrô é de uma geração mais jovem. Ele fez toda a sua escolarização formal na aldeia mebengôkrê do Metyktire e, depois, na aldeia mebengôkrê de Piaraçu, onde ainda estudava. Com isso, não sofreu os percalços daqueles que foram obrigados a se mudar para a cidade ou suas redondezas a fim de freqüentar as escolas urbanas. Todos os outros professores da Escola Goronã passaram por essa trágica experiência.

Wengroi Tapayúna, diferente de Bepkôrô, é o Tapayúna mais versado da aldeia no que tange ao ensino formal. Seu Português é fluente e ele é capaz de produzir um texto dissertativo de várias páginas, nessa última língua, quase sem nenhum erro de gramática normativa. Como visto, esse professor se dedicava a alunos mais velhos que Bepkôro, os quais assumiam as carteiras poucos minutos depois da turma mais jovem ter subido para o círculo da aldeia. Sua aula começava às 9:30 e ia até 11:30. Não havia um sinal sonoro ou qualquer tipo de marcação diacrítica pública, mostrando que uma aula havia terminado e outra aula iria começar. Estudantes e professores se baseavam, até onde pude notar, no fato dos alunos mais novos retornarem e do próximo professor estar se encaminhando para a Escola Goronã. Contudo, a maioria dos homens adultos possui um celular que, além de marcar as horas, não raro serve também como aparelho de som ou vídeo individual. Durante meu período de campo, não havia sinal de Internet ou de celular em Kawerêtxikô, mas homens e mulheres se divertiam assistindo vídeos diversos, de origem indígena ou não-indígena, nesses celulares.

\footnotetext{
${ }^{64}$ A caixa d'água da aldeia havia sido instalada anos antes e passou boa parte do meu período de campo abandonada. Assim, demorou cerca de 3 anos para que os não-indígenas fizessem a ligação da caixa para cada casa e a instalação do conjunto placa solar/motor/bomba a fim de bombear água de um igarapé próximo para a caixa e desta para as casas e a farmácia de Kawerêtxikô. Antes disso, usava-se baldes de plásticos, tonéis e outros recipientes para se armazenas água, buscada no mesmo igarapé.
} 
Relembro aqui que quase todas as casas do círculo de Kawêrêtxikô possuem apenas uma entrada/saída, sempre voltada para o centro da aldeia. Não é difícil, tendo em mente essa configuração, que se saiba quem está saindo da casa de quem ou, por outro lado, quem está se encaminhando para fora do círculo.

Wengroi já escrevia no quadro com letra cursiva. Esta divisão, em que crianças mais novas são alfabetizadas em letra de forma e as crianças com relativamente mais tempo de ensino formal utilizam a letra cursiva é típica da escola comum não-indígena brasileira. Tal prática, contudo, parece ter sido completamente 'fagocitada' pelos professores de Kawerêtxikô. Depois das 10h da manhã, à medida que o sol ia subindo, a permanência na Escola Goronã ia ficando cada vez mais e mais difícil: eu tentava mudar minha carteira para fugir do sol e o mesmo faziam os estudantes, gradativamente. Além disso, os mosquitos iam atacando cada vez mais os presentes.

Wengroi dava aulas de Português. Ele não trabalhava com palavras soltas, mas sim com um texto dissertativo sobre brincadeiras de crianças - texto e brincadeiras não-indígenas. O título do texto era "As brincadeiras existem faz tempo.”. Ele passou algum tempo copiando o texto no quadro e os alunos demoraram mais alguns minutos para escrevê-lo nos cadernos. Era uma aula, portanto, de Português, lecionada, contudo, na língua Mebêngôkrê. A explicação de Wengroi sobre o texto me pareceu mais uma tradução direta do texto do que uma explicação em si. Ele lia uma frase e, depois, repetia a mesma em língua nativa. O texto versava, por exemplo, sobre brincadeiras como a de bolinha de gude ou soltar pipas - as quais eu nunca vi as crianças de Kawerêtxikô brincando ${ }^{65}$.

A turma de Wengroi parece mais adaptada ao ambiente escolar que aquela de Bepkôrô. O alto barulho que, por vezes, os estudantes faziam nos encontros com esse último professor estava reduzido a um leve zumbido nas aulas do primeiro. Duas filhas de Orengô estudavam com Wengroi, além da filha mais velha de Txuakrê. Ao longe, escutava-se apenas o aparelho de som de alguém tocando um forró-eletrônico e, também, o barulho de uma enxada trabalhando a terra. Por vezes era possível notar também o som de algum barco a motor cruzando o rio Xingu.

\footnotetext{
${ }^{65}$ Não acho que essa referência ao contexto dos não-indígenas, o qual as crianças e adolescentes tem pouco conhecimento, seja necessariamente ruim ou 'aculturador'. Eu próprio fui alfabetizado no contato virtual com animais como elefantes, leões e girafas, os quais eu tive pouco ou nenhum contato de fato.
} 
A aula foi monótona. Durante longos períodos, os alunos ficavam focados em seus cadernos, com muito pouco ou quase nenhum barulho ou movimentação. Como Bepkôrô, Wengroi permanecia em sua carteira, do lado do quadro e à frente da sala possivelmente trabalhando em alguma tarefa do seu curso de graduação na Unemat, o qual ainda cursava.

Há algo importante a ser enfatizado nessas situações de aparente monotonia: a ajustada ou convencionada postura dos estudantes e professor ao contexto das aulas formais. Em quase nenhuma outra situação social há um tão grande silêncio e concentração em Kawerêtxikô. Por vezes, quando saíamos para caçar e pescar, ou quando estávamos visitando alguma roça mais distante da aldeia, havia um silêncio parecido. Era um silêncio parecido, mas não o mesmo silêncio, pois em todas as últimas situações havia pouca gente reunida ou um motivo bastante explícito para o silêncio: não espantar a caça ou pesca.

No caso da Escola Goronã, o contexto social é bastante diverso: um grupo de pessoas relativamente numeroso, juntos e, ainda assim, todos reunidos sem nenhum ruído. Não se está caçando ou pescando. O silêncio visa unicamente a feitura individual das tarefas da educação formal. Situação parecida, por exemplo, na Casa dos Homens, seria impossível, ainda que durante a fala de uma liderança ou do próprio cacique nas reuniões formais, em que os homens falam mais baixo para escutar o que outro diz, mas não há um silêncio tão absoluto.

Sobre a organização das falas, de maneira geral, entre os moradores de Kawerêtxikô, mais pontualmente os homens adultos, há um tipo de fala ritual normatizada, explicitamente notada, usada e respeitada por tal grupo. Quando um homem se dirige ao centro da Casa dos Homens e começa um discurso, os outros baixam o volume da voz, ainda que não estejam necessariamente prestando atenção naquilo que é dito. $\mathrm{O}$ orador não dirige seu olhar a ninguém especificamente, e, de pé, falando mais alto que o comum, passa cerca de 5 ou 10 minutos discursando. Por vezes, quando conta um caso, ele indica com o braço em riste a posição do sol no momento do acontecido; ou, se narra uma caçada, imita com o corpo a posição do tiro com a espingarda ou arco-e-flecha, usando onomatopéias para imitar o barulho das armas. É importante notar isso pois esse estilo de fala ou discurso está completamente ausente nas aulas. Todos os professores com quem tive contato dão suas aulas em um tom baixo e possuem uma postura corporal bastante contida durante as mesmas. 
Essa etiqueta no falar não é algo comum a todos os grupos indígenas sulamericanos: Alcida Rita Ramos descreve o seguinte sob um subgrupo Yanomami:

Qualquer rixa na aldeia mobiliza toda a população Sanumá e, com exceção das crianças e pessoas jovens de ambos os sexos, todos participam ativamente, introduzindo argumentos e contraargumentos, em que homens e mulheres falam em altos brados, ao mesmo tempo, o que deixa perplexos aqueles que têm conhecimento limitado da sua língua. (Ramos, 1980: 36)

Esse comportamento se torna notável quando a autora o compara com aquele dos Maiongong, contidos e reservados, evitando até mesmo tocar ou enterrar, eles próprios, seus mortos.

De todo modo, é claro que o silêncio na Escola Goronã não dura o período inteiro das duas horas de aula. Quando os jovens começam a terminar suas cópias o barulho vai, gradualmente, aumentando - mas sem nunca se aproximar daquele máximo que poderia ser escutado nas aulas de Bepkôrô. Da mesma maneira que nas aulas do último docente, só que de forma mais organizada, os estudantes se encaminham para a mesa de Wengroi para que ele desse o visto em seus cadernos. Assim, em vez de todos irem quase ao mesmo tempo buscar o visto do professor, um ou dois alunos se aproximam de sua mesa e, só depois que esses dois estão sentados, outros se levantam para também receber o visto.

Depois da passagem do texto, os discentes são instados a responder um exercício sobre o mesmo. Durante a feitura dessa atividade, nota-se um novo período de silêncio. Alguns alunos se levantam e procuram uma picada no mato próxima à estrutura da Escola para fazer suas necessidades fisiológicas. Não é necessário pedir licença ou autorização ao professor. Um grupo de meninas, possivelmente do mesmo grupo etário e amigas, termina primeiro o exercício e vão, todas juntas, para essa trilha no mato. Nesse momento, Wengroi havia saído comigo para buscarmos fumo no posto-de-saúde e prepararmos cigarros - professores, estudantes mais velhos e observadores podem fumar livremente durante as aulas. Quando voltamos, eu e Wengroi notamos a falta das meninas, que perfaziam pouco mais da metade dos alunos da turma. Ele perguntou, então, a um dos meninos o que havia acontecido. $\mathrm{O}$ 
professor traduziu a fala do estudante para mim e me informou que as meninas haviam terminado o exercício e estavam passeando na picada. Ele não se mostrou minimamente preocupado com esse fato e, talvez prenunciando algum espanto meu, me disse: "elas estão brincando, deixa. Ficar muito tempo sentado, calado, é chato". Depois da volta das meninas, a aula continuou normalmente, com o visto nos exercícios completos dos alunos pelo docente, finalizando-se no horário habitual, por volta das 11:30.

João Marcelo de Oliveira Macena (2007), analisando a educação formal oferecida pelo extinto SPI aos Canela, argumenta que:

Uma dessas medidas [de educação formal ofertada pelo SPI] seria o não uso da palavra escola, para fugir das "conotações negativas que o nome teria para os índios, como de um lugar onde se confina as crianças durante longas horas, submetendo-as a uma disciplina forçada e em prejuízo de outras atividades que lhes parecem mais úteis". (SPI, 1953:11-12). O nome a ser adotado seria Casa do Índio, e deveria funcionar de forma mais livre onde os indígenas circulariam como se estivessem em sua própria aldeia." (idem :48)

Os Tapayúna não evitaram, como visto, o uso do termo "escola". Contudo, todos os professores da Escola Goronã possuem noção do quanto as aulas podem ser cansativas, pontualmente para as crianças e adolescentes. Essa é uma importante diferença a ser notada entre a pedagogia da educação formal em Kawerêtxikô quando comparada à pedagogia não-indígena das cidades: os professores conhecem os estudantes e sabem o quanto pode ser enfadonha as aulas formais. Eles adaptam a pedagogia não-indígena, nesse sentido, para uma maior liberdade dos estudantes durante o período das aulas.

Diferentemente de Bepkôrô, Wengroi não dava aulas de educação física. Contudo, ele, Bepkôrô e Txuakrê participavam ativamente dos jogos de futebol. Orengô, depois de uma picada de cobra na perna em uma expedição de caça mal sucedida, não jogava mais oficialmente pela aldeia, mas ele foi, durante alguns meses, 
treinador do time principal de Kawerêtxikô - o masculino adulto, que venceu a Copa na cidade de São José do Xingu, ganhando algumas centenas de reais de bonificação naquela ocasião. Todo o dinheiro foi divido igualmente entre todos os jogadores e comissão técnica. As mulheres também jogavam, em um time adulto exclusivamente feminino, com amistosos contra outras aldeias, mas nenhum evento do porte da Copa e da movimentação social que o futebol adulto masculino provoca, em toda região incluído aí os Mebengôkrê, Panará, entre outras etnias e, é claro, também os nãoindígenas. Como não é meu objetivo fazer uma etnografia detalhada do futebol em Kawerêtxikô e redondezas, adianto apenas que tal tema é bastante candente na região, envolvendo todo um sistema de correlações sociais que comporta uniformes com brasões e cores próprias das aldeias, hinos cantados em língua nativa, bandeiras e apostas, inclusive em dinheiro, principalmente quando o foco é o futebol adulto masculino. Times mistos de futebol, eu só tive contato quando observava as aulas de educação física de Bepkôrô ou, ainda, quando seus alunos, bastante novos, jogavam sem a observação do professor.

Wengroi, ao escrever algo no quadro, mantinha a data de aula e o nome da Escola que eram escritos inicialmente, nas aulas anteriores. Ele só apagava o conteúdo, caso o quadro não estivesse limpo. Sua letra cursiva era muito bem feita e a organização geral do quadro não deixava nada a desejar quando comparada com experientes professores não-indígenas. Em uma de suas aulas, ele passava um exercício de separação de sílabas em Português. O exercício era composto de três questões, todas copiadas com esmero no quadro, ocupando, cada uma, espaço proporcional às outras.

Esse docente, em outra aula no mês de maio de 2014, ficou responsável por aplicar as avaliações bimestrais para sua própria turma e também para a turma de Nokêrê, que estava viajando para a cidade naquela data específica. Antes de aplicar a prova, ele fez a chamada e, depois, apagou todo o quadro e colocou o cabeçalho da avaliação: "nome da escola", "aluno", "fase”, "data”, "Avaliação de Língua Portuguesa." Depois disso, distribuiu papel A4 para que os alunos copiassem o cabeçalho. Todos ficaram em silêncio na feitura da avaliação, que foi entregue gradualmente por todos os alunos presentes ao professor - o último terminando cerca de 10 minutos antes do final da aula. 
Essa estrutura geral de aplicações de provas valeu tanto para as provas aplicadas em sua própria turma como também para a turma de Nokêrê. Nas turmas de Bepkôrô, o professor entregou a prova já pré-copiada por ele aos alunos, que apenas respondiam as questões e devolviam as provas ao docente. Eram questões de cálculos básicos em matemática, de subtração e adição de números inteiros. Em meu período de campo, foi impossível acompanhar como os estudantes foram avaliados, se parte deles foi reprovada ou não e como era feita a devolução aos discentes de tais avaliações. Sugiro, de toda forma, que a correção e avaliação dos alunos não é tão rígida quanto aquela feita em uma escola tradicional não-indígena.

Tenho essa impressão, inicialmente, pois as turmas da Escola Goronã são mistas em pelo menos três sentidos distintos: os estudantes são do sexo masculino e feminino; o componente curricular ensinado por um professor é diversificado. Por vezes, pode-se começar as aulas revisando um exercício anterior de matemática e continuá-la com uma temática completamente nova, como o trabalho de um texto em Kaykwakhratxi; por fim, há estudantes de vários níveis ou séries que compartilham a mesma aula/turma. Deste modo, as provas entregues por Bepkôrô não eram iguais e estavam dividas a partir da série em que cada aluno era virtualmente localizado. As copiadas do quadro nas aulas de Wengroi seguem a mesma linha: ele apagou e recopiou três versões de provas, uma para cada série. Dada essa estrutura pouco convencional, sugiro que o critério de avaliação também não seja o mesmo que aquele comum às escolas não-indígenas.

Há de se notar aqui que as crianças mais novas, como aquelas das turmas de Bepkôro, podem, se quiserem, acompanhar as aulas mais avançadas. Algumas delas seguem seus irmãos ou, por vezes, seus pais, nas aulas de Nokêrê. O professor, neste caso, dá alguma atividade paralela àquela criança, que passa o período da aula desenhando, tentando imitar a escrita do quadro, brincando pelas redondezas da Escola ou, quando se cansa, deixa o espaço da aula e volta para o círculo da aldeia para se divertir com outros da mesma idade. Imagino que uma situação análoga a essa seria impossível em uma escola comum, não-indígena, na cidade.

Aprendi um pouco mais de Kaykwakhratxi enquanto acompanhava as aulas dos professores da Escola Goronã. Dado que eu era considerado, como dito, um "especialista" na produção de textos em Português e nas aulas formais de Inglês, eu não me sentia à vontade para acompanhar todos os professores da Escola Goronã. Por 
exemplo, tentei acompanhar algumas aulas de Kokokaron, que por vezes substituía Orengô, mas notei que ele ficava pontualmente incomodado com minha presença, ao ponto de parar a aula e perguntar se o que ele estava fazendo (alguns cálculos matemáticos de multiplicação e divisão; mais tarde, a grafia de algumas palavras em Português) estava correto. Essa posição de "especialista" permanecia como que 'arrefecida' quando a aula era sobre Kaykwakhratxi. Todos da aldeia sabiam perfeitamente do meu quase-absoluto desconhecimento dessa língua. Nesse sentido, eu estava mais próximo ao grupo específico de estudantes que assistiam às aulas. Assim, pude acompanhar mais tranquilamente as aulas que eram dadas sobre a língua dos Tapayúna, principalmente as lecionadas por Wengroi.

Como sabia do meu interesse, esse professor chegava a me chamar, ou na casa de Orengô ou na farmácia, quando ia dar aulas sobre tal língua. Pude ser aluno e, ao mesmo tempo, etnografar diversas aulas desse professor, como em um dia em que ele explicava a proximidade dos pronomes em Mebengôkrê e Kaykwakhratxi ou, em outra ocasião, quando ele traduzia algumas frases de Kaykwkhratxi para o Português, em uma turma mais avançada.

Por vezes, mesmo quando o observador era convidado para a aula, ele acabava causando algum constrangimento. Por exemplo, em uma das aulas de Kaykwakhratxi de Wengroi, ele me chamou para fazer um sorteio. Eu iria sortear o nome de um animal, escrito nessa língua e, depois do sorteio, sortearia um aluno para imitar os trejeitos e o som daquele animal para que os outros estudantes tentassem adivinhar qual animal era aquele. Tirei o nome do animal em um saco e, no outro, o nome de uma jovem aluna, com cerca de 13 anos. Ela, contudo, não quis fazer sua imitação pois eu estava lá, observando a aula. Tive que deixar o espaço da Escola e, depois disso, Wengroi me disse que ela imitou o animal perfeitamente - era uma onça ou "roptxi”, em Kaykwkhratxi.

Foi este mesmo Tapayúna que me contou um caso interessante sobre a construção de uma estrutura de alvenaria para a escola da aldeia mebengôkrê do Metyktire. No projeto para tal construção, o engenheiro não-indígena havia desenhado a escola com seis salas de aula. Quatro delas seriam para as aulas dos Mebengôkrê e as outras duas seriam reservadas para os professores e estudantes tapayúna. Houve um grande atraso na efetivação dessa obra e, quando a escola finalmente ficou pronta, os Tapayúna não mais residiam no Metyktire, como descrito no capítulo anterior. 
Portanto, segundo Wengroi, a construção da escola nessa última aldeia só se deu da maneira que se deu, com um número grande de salas de aula, talvez maior do que a população daquela aldeia naquele momento necessitava, porque os Tapayúna moravam no Metyktire na época em que o projeto foi feito. Wengroi, então, dizia jocosamente que até mesmo quando seu povo não estava mais entre o pessoal do Metyktire, ainda assim eles continuavam ajudando-os.

Passo agora para a análise das aulas de um último professor: Nokêrê Tapayúna. Como já disse, essa é a turma com os estudantes mais velhos que freqüentam a Escola Goronã. Possivelmente, parte destes estudantes irá, nos próximos anos, continuar seus estudos em Piaraçu, na Escola de ensino médio Bepkôrôrôtxi. Em relação ao comportamento dos estudantes, não há grandes diferenças entre a turma de Nokêrê e a turma de Wengroi. Contudo, no que tange à organização das aulas pelos dois professores, há uma grande discrepância a ser notada.

Inicialmente, Nokêrê chama constantemente seus discentes à frente para resolver questões no quadro. O fato não é que Wengroi não usasse esse tipo de estratégia; o fato é que Nokêrê é uma liderança política bastante respeitada entre os Tapayúna e a forma como ele interpela seus alunos é distinta daquela de Wengroi. Assim, se nas aulas do último docente o convite para ir à frente soava exatamente como isso - um convite -, nas aulas de Nokêrê a situação era bem outra. Quem era chamado a participar tinha a obrigação de ir à frente e ninguém questionava a interpelação do professor - ver, para o caso de Wengroi, a aluna que simplesmente se negou a imitar o animal enquanto eu estivesse na sala de aula. Não tenho certeza, mas sugiro aqui que esse pode ser um dos motivos para que poucas mulheres freqüentem as aulas de Nokêrê.

Não é somente neste ponto específico que as aulas de Nokêrê diferem da de Wengroi. Nokêrê é o que se pode chamar de um bricoleur $^{66}$ da educação formal em Kawerêtxikô. Ele nunca freqüentou uma faculdade e há vários anos não estudava como aluno em uma instituição de ensino formal, indígena ou não-indígena. De todo modo, ele aprendeu a ler, escrever e falar Português em várias fontes diferentes: com a missão católica que primeiramente fez contato com os Tapayúna; posteriormente, com os não-indígenas que residiam entre os Kinsedje; mais tarde, com os não-

\footnotetext{
${ }^{66}$ Para uma análise da bricolagem na estrutura de pensamento indígena e não-indígena, conferir a seminal obra de Claude Lévi-Strauss O pensamento selvagem (1989).
} 
indígenas, principalmente funcionários públicos, que estavam entre os Mebengôkrê, mas não eram professores formais; depois em curtas temporadas em escolas das cidades da região; e, por fim, em alguns anos no ensino formal instalado dentro da Terra Indígena Capoto Jarinã.

A aula de Nokêrê é heterodoxa como sua formação. Quando escreve no quadro, ele mistura, constantemente, letras de forma com letras cursivas. Quando ele passa textos no quadro, copiados de outras fontes, ele constantemente ignora a pontuação. Assim, o texto figura, tecnicamente, com apenas um único período, composto de quase-infinitas frases. Essa grafia dificulta sobremaneira o entendimento do texto, mesmo quando o leitor é um falante nativo de Português. Além disso, ele, durante as aulas que dá de Português, confunde várias consoantes, como o "g" com o "q" e escreve "guando" em vez de "quando", por exemplo. Sobre a organização do que é escrito no quadro, é impossível dizer, vendo seu quadro depois da aula dada, do que exatamente estava sendo tratado naquela ocasião.

Deste modo, se duas aulas podem ter uma organização completamente diferente uma da outra, então essas aulas são a de Nokêrê e Wengroi. Enquanto a do primeiro é calma e gradual, a do segundo é tensa e cheia de situações constrangedoras. Não há como não se solidarizar com seus alunos, principalmente quando um deles é chamado a participar na frente da sala, sendo instado a escrever ele próprio no quadro. Quando tal estudante não sabe a resposta, então se instaura uma vergonha coletiva na turma e observador - mas ninguém 'sopra' a resposta. Isso só adia a inconfortável situação do estudante. Depois de algum tempo, o professor dá a resposta e o aluno, desolado, volta para sua carteira. Não presenciei nenhum outro lugar, em Kawerêtxikô, em que o embaraço social era tão explícito do que durante essas aulas. Eu, como "especialista", acompanhei de perto apenas duas ou três aulas de Nokêrê, já que achava que minha presença, sentado ao lado dos alunos, aumentava o acanhamento dos mesmos. Consegui boa parte das notas que tenho dessas aulas conversando informalmente com os discentes fora do período das aulas e, também, emulando que estava de passagem pela Escola em direção a outro lugar durante as aulas de Nokêrê.

Contudo, há de se deixar claro que não estou dizendo que as aulas de Nokêrê são ruins - nem mesmo que elas são piores que as aulas de outros professores. Essa é uma diferenciação feita pelos próprios estudantes Tapayúna. De maneira geral, os 
jovens homens da aldeia aproximam uma letra esteticamente bonita e uma boa organização do quadro com o trabalho do bom artesão ou da boa artesã. Volto aqui no seminal artigo de Peter Gow (2010) e a relação entre o letramento e a prática artesã indígena. Comparando os Piro e os não-indígenas, o autor argumenta que:

En la teoría folklórica occidental, la escritura - especialmente el alfabeto - constituye una representación visual de un discurso específico que emana de un autor específico. El relato de Sangama es extraño precisamente porque éste experimenta el texto directamente como una persona que habla, cono "una mujer com la boca pintada"'” (idem :110)

Sangama foi um dos primeiros Piro a ser alfabetizado, freqüentando, inclusive, uma escola de educação formal não-indígena. Como entre os Tapayúna, o letramento e o contato mais estreito com os não-indígenas era uma atividade eminentemente masculina. Mas, para além disso, o ato de saber ler estava intimamente relacionado às práticas xamânicas: "Para los Piro, sólo em conocimiento shamánico tiene la cualidad de tener un origen oculto, y por ello cualquier conocimiento oculto de este tipo necesariamente tiene que tener algo de conocimiento shamánico." (ibid idem :115).

Fora o fato da docência ser um atividade exclusivamente masculina, não me foi possível notar quase nenhuma relação mais íntima entre o tratamento xamânico e o cotidiano educação formal oferecida na Escola Goronã. O já citado pajé Wotkàtxi era, até onde eu tenho conhecimento, quase que completamente analfabeto, sabendo apenas assinar seu nome - o que não colocava em xeque sua fama regional como excelente curador. O letramento está, em Kawerêtxikô, intimamente relacionado aos homens adultos de uma nova geração, posterior à formação do pajé Wotkàtxi ou do cacique Roptyktxi. Nokêrê, nesse sentido, é um estranho no ninho e o único homem de Kawerêtxikô que, na sua idade, escreve e fala razoavelmente bem o Português. Retomarei na conclusão essa comparação do papel do wajanga ou pajé e o conhecimento formal.

De todo modo, nunca vi os julgamentos negativos da docência de Nokêrê sendo feitos explicitamente na presença dele. Os comentários negativos sobre sua aula me foram repassados em conversas informais, principalmente quando estávamos 
presente somente eu e um jovem homem indígena, mais ninguém. Em uma dessas ocasiões, um jovem morador de Kawerêtxikô talhava um bonito cabo para seu machado. Depois de conversarmos sobre as aulas de Nokêrê, eu fiquei impressionado com sua apurada técnica e lhe perguntei como ele havia aprendido a fazer aquilo. Sua resposta foi a seguinte:

Todo mundo que é gente sabe fazer uma coisa parecida, até criança. Você devia saber. Eu é que fico pensando como você sabe falar e escrever em Inglês, sabe escrever bonito no quadro e não sabe fazer um cabo do machado. Todo mundo que é gente sabe fazer uma coisa assim, já bem muito novo.

Há duas características bastante importantes na fala acima: primeiramente, a já citada correlação entre o efetivo letramento e o trabalho do artesão; além disso, a demonstração de que o aprendizado comum se dá pelo interesse do observador no intuito de descobrir os segredos de uma prática pela qual ele tem interesse, mas ainda não a domina. Deste modo, é principalmente o conhecimento não-indígena que precisa passar pela formalidade escolar: outros conhecimentos são adquiridos pelo já citado fascínio do observador daquela determinada prática. Nesse ponto, os Tapayúna voltam a se aproximar dos Piro: não há escolas formais para se ensinar os xamãs; o que existe são xamãs que, como Sangama, podem aprender a ler, desvelando um dos segredos dos não-indígenas.

Finalizando a descrição das aulas da Escola Goronã, é preciso insistir no fato que Nokêrê não ensina neófitos: todos os seus alunos já possuem anos de estudo formal. Por vezes, estes próprios estudantes corrigem o professor em situações específicas. Nesses casos, não há qualquer sinal de timidez de Nokêrê, que rebate a ajuda do aluno com um sorriso espirituoso, agradecendo ${ }^{67}$, corrigindo o erro e continuando a aula.

\footnotetext{
${ }^{67}$ Há duas maneiras de se cumprimentar ou agradecer as pessoas em Kawerêtxikô, algo próximo ao "obrigado" em Português: Wetxi, termo em Kaykwakhratxi que quer dizer, entre outras coisas, algo próximo a "Bonito"; e a saudação mais comum em todo o território Capoto Jarinã, o Mei kum mré dos Mebengôkrê, tendo a mesma função social de indicar algo bonito. Ainda sobre o mesmo tema, logo depois de um jogo de futebol, eu pedi que um dos Tapayúna me dissesse como falar "Me desculpe" em Kaykwakhratxi. Depois de muito tempo debatendo com Wengroi, Orengô me ensinou a falar uma expressão que, traduzida ao Português, queria dizer: "Eu não quis fazer o que eu acabei fazendo." Não
} 
Pode-se notar, por outro lado, que as aulas de Nokêrê instam os estudantes a participar mais ativamente das mesmas, ainda que de uma maneira que poderia ser classificada pedagogicamente, a posteriori, como não ideal, pois muito vexatória. É possível acrescentar, ainda, que, enquanto a posição de a-luno, ou seja, sem luz, sem conhecimento, é a posição comum dos estudantes nas outras aulas, nas de Nokêrê há um desafio a tal lugar-comum. Tanto o professor desafia os estudantes a, em público, mostrar o que aprenderam, como também estes últimos, de um lugar sabidamente assimétrico frente ao professor (e talvez daí a maior importância dessa contrainterperlação dos estudantes), podem corrigi-lo e, indiretamente, dar a entender que sabem, no mínimo, tanto quanto ele.

Sobre interpelações e contra-interpelações, faço uso aqui do polêmico estudo do sociólogo Louis Althusser sobre os Aparelhos Ideológicos de Estado (Althusser, 1985). É claro que não concordo com a visão do sociólogo francês de que a instituição escolar seja apenas um substituto da religião no aprendizado da ideologia capitalista. Contudo, nessa obra, há uma passagem específica (idem, :99-100) em que o autor fala da situação de um transeunte qualquer que é abordado por um policial e, ainda que não tenha feito nada de errado, se situa como sujeitado para ser checado pelo policial. É justamente essa abordagem e a sujeição posterior que pode ser interessantemente classificada como uma interpelação. Deste modo, interpelações quase-queobrigatórias, que lembram essa passagem do policial e do transeunte em Althusser, eu só pude notar nas aulas de Nokêrê.

De todo modo, há algo importante em se conseguir mostrar, em público, que se aprendeu ou mesmo que se está aprendendo algo. Experimentei isso no meu trabalho de campo ao perceber que a recepção que as pessoas em Kawerêtxikô me davam melhorava bastante depois que eu aprendi alguns cumprimentos básicos na língua delas. Era possível notar que eu estava interessado em coisas que elas dominavam e eu não - e assim, elas poderiam efetivamente me ajudar. Por exemplo, certa feita, depois de vários meses vivendo entre os Tapayúna, um jovem homem de origem mebengôkrê falou uma frase em Kaykwakhratxi e me perguntou o que significava. Eu não consegui traduzi-la corretamente para o Português e, jocosamente, o jovem disse que eu ainda não sabia nada de Kaykwakhratxi. Respeitosamente

há, até onde pude entender, uma expressão simples que designe algo próximo ao "Me desculpe" do Português. 
concordei com ele, mas disse que, com o passar dos anos pesquisando os Tapayúna, eu iria melhorar meu conhecimento de Kaywkahratxi.

\subsection{A educação formal em Kawerêtxikô em perspectiva}

Dada a descrição de algumas aulas e do contexto social em que as mesmas aconteceram, o que se pode generalizar, a partir daí, do cotidiano da vida em Kawerêtxikô? Primeiramente, penso existir, ainda que em forma 'germinal', um contexto propício de valorização da escrita de maneira diferente da que se dava antes da instalação da Escola Goronã e da contratação de professores e outros funcionários indígenas.

No contato com os não-indígenas, saber ler e ou lidar com outras técnicas dos não-indígenas pode ser a diferença entre a vida e a morte. Em minha dissertação de mestrado (Alcântara Neto, 2007) analiso, a partir de documentos do Judiciário Nacional, o julgamento por crime de genocídio de um grupo de garimpeiros nãoindígenas falantes do Português que chacinaram um sub-grupo yanomami residente na aldeia de nome Haximu. A tragédia ganhou repercussão internacional ("Caso Haximu") e o grupo de não-indígenas acabou sendo condenado por genocídio étnico, o que foi a primeira condenação por tal crime no Judiciário brasileiro.

A partir da documentação ajuntada no Caso Haximu, conjunto documental tradicionalmente batizado pelos operadores do Direito como um "processo judicial", pode-se notar que os garimpeiros se comunicavam entre si a partir de papéis dados aos indígenas a serem entregues a outros garimpeiros. Os indígenas certamente achavam que tais papéis serviriam como garantia de dádivas dos não-indígenas invasores, recém chegado na região tradicional dos Yanomami. Alguns bilhetes escritos pelos genocidas não-indígenas podem ter sido requisições de dádivas aos de Haximu, o que garantia aos garimpeiros que os indígenas não fariam guerra contra eles, ao menos no curto prazo, tendo como base o recebimento dessas certos presentes, como cobertores ou machados de aço, por exemplo. Mas um recado específico, que foi entregue por um homem haximu a um garimpeiro a pedido de um terceiro garimpeiro, dizia explicitamente: "faça bom proveito desses otários". Os não- 
indígenas já pensavam em sair da área e estavam postergando os pedidos de presentes dos indígenas yanomami. Assim, ao mesmo tempo que os garimpeiros passaram a dar a entender que iriam dar os presentes em um momento posterior, eles já tramavam o genocídio completo daquelas pessoas por escrito. Os garimpeiros brasileiros organizaram uma emboscada em Haximu e mataram, a tiros de cartucheiras e golpes de terçado, boa parte dessa aldeia yanomami.

Deste modo, o não-domínio de uma técnica específica fez com que aquele sub-grupo Yanomami estivesse, sem saber, refém dos garimpeiros. Os de Haximu entregaram sua sentença de morte aos próprios algozes. Não estou dizendo, com isso, que dever-se-ia ensinar todos os Yanomami a ler e escrever. Noto apenas que o fato de ignorar uma técnica específica, quando potenciais inimigos a dominam e, mais ainda, sabem que aqueles outros com quem estão em contato regular não sabem nada sobre ela, é uma situação potencialmente assimétrica a favor daqueles que dominam a referida técnica - principalmente quando esta técnica está diretamente relacionada à comunicação.

Os Tapayúna, que tem um histórico de contato com os não-indígenas bastante diferente dos grupos Yanomami, estão, hoje, cientes das assimetrias relacionais frente aos não-indígenas e, assim, estão se organizando para contorná-las. O que os espreita, contudo, é a potencialidade de, nesse movimento de aprender certas técnicas nãoindígenas a fim de travar relações sociais menos assimétricas com estes, eles estejam descontroladamente se tornando esses outros. Relembro aqui o caso dos Xikrin estudado por Cesar Gordon (op. cit.), no início do presente capítulo ou então a maneira como adolescentes e adultos estão se adaptando ao contexto geral das aulas formais, permanecendo em silêncio durante a maior parte das mesmas e se submetendo a relações diretas de comando-obediência ${ }^{68}$, como descrito acima. Há, além desses exemplos, a difusa noção de que os Tapayúna estão ficando mais "moles" ou "cansados" depois do contato sistemático com os não-indígenas. Sugiro que essas relações morosas, "chatas" no dizer do professor Wengroi, são quase que exclusivas do contexto escolar ou de reuniões que se assemelham às aulas formais - apesar de,

\footnotetext{
${ }^{68}$ Faço referência, nessa passagem, à categoria usada por Pierre Clastres (1978) sobre determinada tradição não-indígena de organização social. Segundo o autor, “[...] onde o político se determina como campo fora de toda coerção e de toda violência, fora de toda subordinação hierárquica, onde, em uma palavra, não se dá relação de comando-obediência. Está aí a grande diferença do mundo indígena o que permite falar das tribos americanas como universo homogêneo, apesar da extrema variedade de culturas que ai se movimentam." (idem :10)
} 
como visto, a submissão à categoria de aluno não ser obrigatória. Ao contrário, como veremos no próximo capítulo, a de "paciente" é pressuposto de qualquer tratamento alopático, fora ou dentro da aldeia.

É claro, então, que a vantagem relativa de poder ler os códigos gráficos dos não-indígenas tem conseqüências outras, em Kawerêtxikô e outros lugares, do que o simples domínio de uma técnica. A etnografia da Escola Goronã mostra justamente esses outros efeitos que advém da tentativa de dominar o processo da escrita, entre outros. Quando os Tapayúna precisavam se mudar para a cidade no intuito de ganhar conhecimento e domínio dessas práticas antes alienígenas, o problema de estar tornando-se não-indígena era explícito. Porém, como apenas alguns jovens homens indígenas se arvoravam a viver grandes períodos de tempo nos centros urbanos, a dificuldade aí estava individualizada e, assim, relativamente sob fácil controle. Com a instalação do ensino formal na Terra Indígena Capoto Jarinã, essa conjuntura tende a se inverter: a questão de estar se transformando em não-indígena tornar-se menos explícita ou direta, pois estamos falando de uma escola diferenciada: os professores dão as aulas em línguas conhecidas pelos estudantes e, de maneira geral, a instituição de ensino está relativamente inserida no cotidiano da aldeia, com aulas diárias de diferentes componentes. A grande maioria das crianças e adolescentes, por outro lado, tem contato agora com o ensino formal - e não apenas um jovem específico que se mudou, durante uma temporada, para a cidade. Portanto, tal problema agora é coletivo, difuso e mais complicado de ser efetivamente controlado pelas lideranças.

Avaliando politicamente essas questões, a maioria dos Tapayúna optou pela seguinte escolha política: não deixar mais seus membros se mudarem, ainda que temporariamente, para as cidades da região e, ao invés disso, construir uma escola diferenciada dentro de sua própria aldeia. Como dito acima, apenas poucas famílias não mandam seus filhos para a Escola Goronã. De todo modo, as possibilidades de escolha continuam sendo bastante restritas: ou se vai para a cidade, ou se estuda na escola diferenciada ou, por fim, não se adquire as técnicas necessárias para uma relação com os não-indígenas menos assimétrica. Uma outra saída, no máximo, é tentar adquirir tais técnicas de maneira heterodoxa, a exemplo da liderança Nokêrê, opção que, em si, traz outros problemas. Não é possível dizer, com certeza, se tal disposição dos indígenas de tentar 'tapayunizar' o ensino formal, inclusive ensinando o Kaykwakhratxi para crianças que aprenderam como primeira língua o Mebengôkrê, 
é a mais acertada ou mesmo se ela perdurará a longo prazo. Contudo, essa escolha tem já mostrado algumas vantagens relativas: a maior delas talvez seja a gradual independência de mediadores, entre eles os antropólogos, nas relações cotidianas entre indígenas e não-indígenas.

No início dessa última subseção, disse que, com a Escola Goronã, havia melhor condições para a valorização da comunicação explicitamente gráfica, escrita, entre outras técnicas, do que quando não existia o ensino formal dentro na aldeia. Baseio esse argumento, inicialmente, na existência da própria estrutura física da Escola: local utilizado não somente para as aulas formais dos professores e estudantes indígenas, mas também, por exemplo, para aulas de Kaykwakhratxi para instruir um observador curioso ou, ainda, aulas de Inglês para os homens indígenas, no intuito de ampliar as possibilidades de contato com outros não-indígenas que não somente os brasileiros. Além disso, penso que o fato dos professores, entre outros funcionários indígenas, receberem salários, viajarem constantemente para os centros urbanos da região e conseguirem negociar e se relacionar de forma independente com os nãoindígenas, é também um alento para que outros indígenas tenham maior interesse pela educação formal: é justamente a vantagem relativa de se estar ficando mais "mole". Não há dúvidas que o risco de se estar perigosa e descontroladamente se aproximando dos não-indígenas, no recebimento de salários e constante viagens para as cidades, é bastante explícito. Contudo, como vimos no capítulo 2, o que é recebido em dinheiro, em parte, vira dádivas e contra-dádivas num sistema econômico interétnico que não está completamente capitalizado.

Não é meu interesse, na presente pesquisa, tentar dizer como os Tapayúna estarão daqui cinco ou dez anos. O que pretendo, na verdade, é acompanhá-los durante esse período ou mais, se for possível. Tendo em vista o contexto atual, penso que a tentativa de englobar a educação formal e, ainda assim, continuar se autoreconhecendo e ser reconhecido como indígena, mais pontualmente como Tapayúna, é uma aposta que pode efetivamente funcionar - ainda que não se possa ter certeza desse funcionamento. Até mesmo os pesquisadores mais pessimistas em relação ao ensino formal no contexto das aldeias indígenas, como Wilmar D’Angelis (2012), pontualmente discutido no capítulo 1, podem argumentar que: 
A questão da construção de uma "escola indígena" - isto é, de programas de educação escolar geridos pelas comunidades indígenas, e não para eles ou com elas - é o lugar de um embate que pode ser o embrião de processos de verdadeira autonomia de um movimento indígena e de sociedades indígenas no Brasil (ênfases do original, idem :16)

Assim, se os Tapayúna não gerenciam, por exemplo, os remédios na farmácia ou posto-de-saúde, eles, por outro lado, cuidam da melhor maneira possível do material escolar que é recebido para as aulas na Escola Goronã. Além disso, se esforçaram para participar do curso oferecido em 2012 por Maria Eliza Leite, funcionária aposentada da Funai, para produzir material didático de alfabetização em sua própria língua. Mais que isso, eles chegaram a produzir documentos escritos pedindo verbas suplementares para a Escola - e realmente conseguindo-as. Organizaram-se, mais tarde, para usar essa verba no intuito de construir melhores instalações para as aulas formais e conservação do material didático dentro da própria aldeia, depois prestando contas às instituições não-indígenas sobre tais gastos. Não há nada parecido com isso na gerência do posto-de-saúde, como mostrarei no próximo capítulo.

A Escola Goronã é, espero ter deixado claro, um espaço muito mais livre que uma escola comum não-indígena. Irmãos podem levar outros irmãos mais novos e pais podem levar seus filhos para as aulas, sem maiores problemas. As crianças e adolescentes usam a estrutura da Escola não somente no momento de suas próprias aulas - e aqui falo não só do espaço físico das aulas, mas, por exemplo, da rede e bola de vôlei, da bola de futebol e mesmo do laptop e impressora destinados à digitação e produção dos documentos escolares, todos passíveis de uso fora do contexto restrito do ensino formal, ainda que também neste último espaço social. Wengroi não tinha laptop próprio e usava o da Escola Goronã para seus afazeres de faculdade. Nessa mesma toada, os estudantes possuem liberdade para deixar uma aula quando bem entenderem, até mesmo as crianças mais novas das aulas de Bepkôrô. Ao invés de altos muros cobertos com arames farpados, cena típica de escolas públicas e particulares não-indígenas, a Escola Goronã não possuia nem mesmo paredes laterais. As próprias aulas de Inglês, que eu lecionava a pedido dos Tapayúna, tiveram fim 
quando os homens jovens da aldeia decidiram que seria mais interessante para eles, naquele momento, treinar para o campeonato de futebol organizado por não-indígenas da cidade de São José do Xingu do que tentar aprender aquela língua estranha nãoindígena, bastante diferente do Português.

Contudo, ainda não há uma comunidade produtora e consumidora de uma literatura escrita na aldeia Kawerêtxikô, nem tão pouco na região da Terra Indígena Capoto Jarinã. Isso é bastante claro, principalmente quando seguimos o conselho de Wilmar D’Angelis, em outra obra (2007) e pensamos em uma tradição de escrita em língua nativa que 1) não esteja relacionada a produção de cartilhas de alfabetização e 2) não esteja relacionada a consumação de um projeto proselitista (idem). Se tirarmos essas duas possibilidades, muito pouca coisa é produzida no Brasil em língua nativas - e isso também vale para o caso específico dos Tapayúna. Sobre a transcrição de mitos, assevera o autor que "[...] a mera transposição, para a escrita, de um texto da literatura oral, não constitui uma literatura escrita." (ibid idem :24).

De todo modo, essa literatura ou tradição literária escrita, se algum dia florescer entre determinado grupo auto-reconhecido e também apontado por outros como indígena, precisaria, no mínimo, de escritores/leitores, ou seja, de pessoas que saibam decifrar a convenção de códigos gráficos de determinada língua. Essa me parece ser a principal 'semente' da Escola Goronã na constituição de uma possível comunidade literária entre os Tapayúna - tendo em mente que os Tapayúna mantenham o interesse que possuem hoje na escrita do Português, do Mebengôkrê e do Kaykwakhratxi.

Por fim, gostaria de tratar de um último assunto: a participação massivamente maior dos homens na educação formal da aldeia Kawerêtxikô, quando comparado às mulheres. Tal fato está relacionado, em minha opinião, a uma questão sociológica maior: a ideal ou genérica divisão de gênero entre os Kaykwakhratxi. Tentei mostrar, no início deste capítulo, que a inovação, entre os Jê, se dá preferencialmente como um espólio de guerra. Não há dúvidas de que a guerra é, para esse grupo, entre outros, uma atividade eminentemente masculina. Pode-se mesmo dizer que as mulheres são, principalmente, conservadoras das coisas, enquanto os homens são desbravadores ou descobridores. Não são elas que abrem a clareira no mato para se fazer roças, mas são elas que cuidam da plantação para manter a roça; não foram elas que abriram, em 2006, o círculo central do pátio da aldeia Kawêrêtxikô, mas são elas que cuidam, 
cotidianamente, para que o círculo continue sendo um círculo, capinando o mato e rastelando a sujeira; não são elas que constroem, idealmente, a casa de moradia, entre outras, mas são elas que, de fato, cuidam da limpeza e da manutenção da mesma. Aproveitando, inclusive, a ambigüidade, em Português, do termo "conservador", as mulheres usam certos vestidos longos e coloridos que, na cidade e em meio aos nãoindígenas, as diferenciam no primeiro olhar das mulheres não-indígenas. A roupa dos homens, tanto na aldeia como na cidade, são quase que praticamente as mesmas que a dos não-indígenas - ao menos em períodos não-festivos. A vestimenta cotidiana feminina pode ser vista, assim, como duplamente conservadora: tanto no sentido de que elas conservam uma diferenciação diacrítica, explícita, em relação aos nãoindígenas como também pelo fato de que esses não-indígenas classificam tal vestimenta como não-adaptada à modernidade que eles próprios se intitulam com repositórios e divulgadores - são, em sentido positivista ou do evolucionismo social, "vestimentas conservadoras". 


\section{Capítulo 4. Uma etnografia da saúde alopática em Kawerêtxikô}

Para introduzir a etnografia do posto-de-saúde ou farmácia - ao contrário da Escola Goronã, essa instituição não possui nome próprio - é interessante começar com a freqüência que os diferentes profissionais não-indígenas da terapêutica alopática visitavam Kawerêtxikô. Os plantões das técnicas em enfermagem eram normalmente de 20 dias consecutivos. Elas trabalhavam em uma escala de 1/1, ou seja, folgavam um dia para cada dia trabalhado. Já as enfermeiras, apesar de terem o mesmo período habitual de plantão, possuíam o dobro de folgas que as técnicas, numa escala de 1/2: para cada dia trabalhado, folgavam dois dias. Os médicos, dentistas e farmacêuticos apareciam menos regularmente e combinavam individualmente seus plantões. Por exemplo, pude encontrar, durante quatro dias, os dois dentistas que trabalhavam em Kawerêtxikô e na região. Eles escolheram, na negociação de seus plantões, passar uma temporada de 4 meses nas aldeias da Terra Indígena Capoto Jarinã e, depois disso, 6 meses de folga, ambos períodos consecutivos. Os médicos e farmacêuticos possuíam a mesma liberdade para negociar seus plantões. Encontrei os primeiros em seis ocasiões específicas, atendendo em Kawerêtxikô e também na aldeia mebengôkrê de Piaraçu; os últimos pude encontrar apenas em uma única oportunidade nos 13 meses não-consecutivos de trabalho de campo.

Não tive chance de saber a remuneração exata de médicos, dentistas ou farmacêuticos. Contudo, as técnicas de saúde recebiam por mês, pouco mais de dois mil reais. Nesse montante já estavam inclusos os adicionais para o reabastecimento do botijão de gás e a compra do rancho dos plantões. As enfermeiras recebiam pouco mais do dobro desse valor. Um delas me informou que havia uma gradação de salários que se iniciava com as técnicas e enfermeiras, passava pelos dentistas e farmacêuticos e se finalizava nos médicos, os mais bem remunerados. Havia uma exceção a ser feita: os médicos cubanos trabalhavam com um contrato diferente, feito diretamente entre os Estados nacionais do Brasil e Cuba. O comentário geral de seus pares e companheiros de plantão era de que eles trabalhavam mais e recebiam substancialmente menos que os médicos brasileiros.

Todos os profissionais com quem tive contato reclamavam da precária estrutura de atendimento. Um casal de médicos cubanos que fazia uma visita à 
Kawerêtxikô se queixou pontualmente da falta de uma maca para deitar os "pacientes". Os dentistas, por sua vez, disseram que os produtos adquiridos para obturações e outros procedimentos eram de péssima qualidade. Para tratamentos mais eficazes, eles próprios compravam alguns desses materiais. No mais, eles atendiam os indígenas com os últimos sentados nas cadeiras da Escola Goronã, já que não existiam poltronas de dentista.

O mesmo acontecia com as técnicas e enfermeiras. Há um caso emblemático que pude acompanhar pelo rádio do posto-de-saúde em Kawerêtxikô. Uma experiente técnica dizia que não havia mais qualquer medicação e materiais para curativos na aldeia em que ela era plantonista e que ela estava medicando os doentes com remédios que ela trouxera para ela própria e improvisando a maioria dos curativos. Essa profissional pedia, então, que avisassem sua irmã na cidade para que comprasse mais medicamentos básicos na farmácia privada, como ácido acetilsalicílico, soro para desinfecção, bandagens, esparadrapos, entre outros produtos. Sua irmã deveria mandar esse reforço pelo próximo carro ou avião da saúde que entrasse na região. Encontrando meses depois essa profissional na cidade, ela disse que ainda não havia sido ressarcida por tais gastos e que desconfiava que não seria fácil conseguir tal ressarcimento.

Uma situação parecida foi vivida por um dos dois homens técnicos em enfermagem que encontrei nos plantões em Kawerêtxikô. Uma mulher havia cortado a perna enquanto trabalhava rachando lenha com um machado, típica ocupação das mulheres em toda a região da Terra Indígena Capoto Jarinã. O corte era profundo e precisava ser suturado. Contudo, não havia linha nem tão pouco agulhas específicas para se fazer tal sutura. O plantonista improvisou, então, uma outra linha e agulha, não específicas para a sutura de ferimentos, pois a mulher estava perdendo muito sangue com o ferimento aberto.

Sobre a função desempenhada por cada um desses profissionais, relembro aqui a discussão do Ato Médico feita no capítulo 1. As aplicações de injeções intramusculares ou venosas, já prescritas anteriormente por um médico, ou, como visto, a feitura de suturas e drenagens de ferimentos infeccionados, inclusive com a realização de anestesias locais injetáveis, eram trabalhos comumente realizados pelas técnicas de saúde e enfermeiras. É claro que, caso o Ato Médico tivesse sido sancionado pela presidente Dilma Rousseff com a redação original do Congresso, 
essas intrusões terapêuticas dos corpos seriam, tecnicamente, uma exclusividade dos médicos.

As técnicas em enfermagens e enfermeiras se juntavam, ainda, para as ações de vacinação da população indígena, principalmente as crianças e adolescentes. Pude acompanhar uma ação desse tipo em Kawerêtxikô. As injeções intra-musculares ou gotas via oral eram responsabilidade das técnicas. As enfermeiras preenchiam o cartão de vacinação e conferiam quais vacinas deveriam ser tomadas e quais não. Depois, repassavam tais informações às técnicas, que administravam as vacinas. Como não havia energia elétrica na aldeia capaz de fazer funcionar constantemente um refrigerador, as doses eram todas guardas em caixas de isopor, refrigeradas com pedras de gelo advindas da cidade. Tal ação de vacinação percorreu, pelo que me foi dito, todas as aldeias da região, contando com uma equipe fixa e a eventual ajuda daqueles que estivessem de plantão na aldeia em questão.

Os indígenas, ao menos os de Kawerêtxikô, apenas encaminhavam seus filhos para a farmácia e observavam o trabalho das profissionais de saúde durante a vacinação. Em sua maioria, as crianças menores que 2 ou 3 anos começavam a chorar antes de tomarem a injeção, já na porta da farmácia. As mais velhas e adolescentes faziam uma cara de poucos amigos, mas tomavam a vacina sem chorar. É interessante notar aqui que uma das ameaças mais repetidas pelas técnicas e enfermeiras mais experientes, em Mebengôkrê, era dizer que iria aplicar uma injeção (kanu) em crianças que, por exemplo, estavam brincando na enxurrada depois de uma chuva ou fazendo outras ações que, para as profissionais de saúde, pudesse ser classificada como anti-higiênicas.

Assim, de maneira geral, as enfermeiras e técnicas eram as profissionais mais assíduas em Kawerêtxikô. Idealmente, nenhuma aldeia de porte médio poderia ficar "descoberta", ou seja, sem ao menos uma técnica em saúde como plantonista. As aldeias mais populosas, como Nascepotiti, Metyktire ou Piaraçu, sempre contavam, também idealmente, com uma enfermeira, além de duas técnicas. Kawerêtxikô não era uma aldeia das menores: possuía, pelo menos, uma técnica de saúde. Como veremos, as pequenas comunidades mebengôkrê do Bytire e Kromari também eram responsabilidade do técnico ou outros profissionais que estivessem em Kawerêtxikô.

Quando me mudei para o posto-de-saúde, eu não sabia o que iria encontrar. Focava minha observação, até então, na educação formal, tema inicial da minha 
pesquisa. Contudo, os próprios tapayúna tratavam o trabalho na educação formal e saúde alopática oferecidas pelo Estado brasileiro de maneira conjunta. Em determinadas situações, os professores indígenas, por exemplo, organizavam suas viagens junto com o Agente Indígena de Saúde e o de Saneamento. Eles também compartilhavam o frete com o motorista não-indígena para trazer os produtos comprados nas cidades da região. Além disso, todos os empregados indígenas, nessas duas áreas, eram homens e precisavam ter alguma noção do Português falado e também de como negociar, dentro e fora das cidades, com os não-indígenas. Acrescenta-se à isso, o fato da construção das estruturas físicas tanto da saúde alopática quanto da educação formal estarem fora do círculo da aldeia Kawerêtxikô. Essas coincidências me motivaram a tentar compreender melhor como os Tapayúna se relacionavam com esses dois serviços prestados pelo Estado brasileiro. A partir de então, comecei a olhar com maior cuidado para a estrutura do posto-de-saúde, notando diferenças e semelhanças com o contexto que eu já conhecia melhor da educação formal da Escola Goronã.

Assim, pela experiência que eu já havia tido, imaginava que iria encontrar mais homens e menos mulheres nos plantões de enfermeiros e técnicos em locais relativamente isolados que são as aldeias. Pensava que esses homens teriam uma idade não muito avançada e seriam, em sua maioria, jovens, como na Escola Goronã. Pensava, também, que esses jovens seriam majoritariamente solteiros. Ora, como já dito, a maioria quase absoluta dos enfermeiros e técnicos em enfermagem eram mulheres. Além disso, havia uma divisão bastante homogênea entre jovens na casa de 20/30 anos e pessoas mais velhas, na faixa dos 40/50 ou até mesmo dos 60 anos. Por fim, o único preconceito confirmado é que realmente há mais profissionais solteiros do que casados, mas ainda assim não em muito maior número.

Feito esse 'sobrevôo' do posto de saúde, reitero algumas diferenças básicas entre a farmácia e a Escola. Como deixei claro no último capítulo, todos os professores e outros funcionários dessa última instituição são homens de Kawerêtxikô. Além da maioria dos profissionais do posto-de-saúde ser composta por mulheres, nenhuma delas é indígena. No mais, não há a possibilidade, por exemplo, de se pedir algum tipo de verba emergencial para a farmácia, ao menos uma que seja gerida diretamente pelos Tapayúna, como no caso da Escola Goronã. Assim, toda a administração e o trabalho direto está nas mãos dos não-indígenas. Como veremos, 
tais fatos só reforçam o caráter de "pacientes" que os tratados pelo posto-de-saúde precisam se sujeitar a fim de ter acesso à terapêutica não-indígena.

Com isso, no próximo tópico, irei narrar um acontecimento que pude acompanhar de perto: uma tensa discussão entre um funcionário da saúde alopática, segundo e último homem que encontrei nessa função, e um jovem homem indígena, morador de Kawerêtxikô. Como mostrarei, esse não-indígena pode ser bem classificado como mais próximo ao pólo "administrar" ou "técnico" da tensão entre "cuidar e administrar" construída por Cristina Dias da Silva em sua etnografia da saúde não-indígena oferecida aos Munduruku (2010). Ressalto que rusgas como a que apresentarei não eram de todo incomum em Kawerêtxikô, principalmente entre homens indígenas e profissionais da saúde alopática com pouca experiência nos plantões em aldeias da Terra Indígena Capoto Jarinã. Na verdade, como veremos, aqueles que ficavam dois anos ou mais no trabalho eram justamente os que conseguiam lidar eficazmente com tais situações de estresse entre a população local e as premissas típicas da terapêutica alopática.

Depois disso, mostrarei como as técnicas de saúde efetivam o tratamento alopático em Kawerêtxikô. O subtópico seguinte tratará das relações dos habitantes dessa última aldeia com os não-indígenas quando os primeiros precisavam ir para os centros urbanos da região a fim de se submeter a procedimentos da terapia alopática que não estavam disponíveis na aldeia. Finalizando o capítulo, farei algumas considerações sobre terapêutica indígena quando comparada ao tratamento de saúde alopático.

\subsection{A dupla submissão: assimetrias em uma discussão no cotidiano de um plantão}

A discussão ocorreu entre um dos raros homens não-indígenas que ocupou essa função e, por outro lado, um jovem homem mebengôkrê. Este último era casado com uma mulher tapayúna, casal já com diversos filhos e residente em Kawerêtxikô desde a fundação da aldeia, em 2006. Eles já habitavam uma casa independente dos pais da noiva, sinal de uma posição social mais prestigiada. 
Quando encontrei o referido técnico, eu estava me mudando da casa de Orengô para a farmácia. Depois de ter o aval positivo dos Tapayúna, fui negociar com quem estava de plantão no posto minha mudança para o novo local. O técnico se mostrou bastante tranqüilo em relação a isso: disse que eu poderia, sem problemas, dividir a comida e, além disso, o gás de cozinha ${ }^{69}$ com ele no período em que durasse seu plantão. Ressaltou apenas que minha permanência no posto-de-saúde não era garantida depois disso e que, assim, eu deveria negociar minha estadia novamente com quem assumisse o plantão em seu lugar. Se para ele não havia qualquer empecilho, poderia haver para quem chegasse e, por ventura, tivesse uma opinião diferente. Ele advertiu, ainda, que a maioria dos técnicos plantonistas eram mulheres e que, deste modo, alguma delas poderia ficar mais receosa em dividir a farmácia com um homem. De todo modo, paguei em dinheiro a metade do que o técnico havia gasto com o botijão de gás e seu rancho e passamos a viver juntos na farmácia.

Para minha felicidade, nenhum(a) profissional plantonista se negaria a dividir comigo a residência e o gás de cozinha. De todo modo, a partir de então, eu sempre traria um rancho individual para cobrir cerca de um mês em Kawerêtxikô - e, do mesmo modo, sempre daria em dinheiro metade do preço do gás de cozinha para a pessoa que estive de plantão na aldeia. Reitero, ainda, que os plantonistas sempre traziam ranchos e gás de cozinha para um período maior que um mês, já que, não raro eles eram solicitados a passar alguns dias a mais no plantão do que a estada oficial de 20 dias.

\footnotetext{
${ }^{69}$ Os Tapayúna cozinhavam normalmente com lenha da floresta, arranjada em uma armação de arames e pedras. As únicas casas que possuíam fogão a gás eram a do cacique Roptyktxi e a do então diretor da Escola Goronã, Txuakrê. Depois de minha mudança, dei de presente um fogão a gás usado para Orengô (cf. Introdução). Algumas semanas depois, ele conseguiu comprar e trazer para a aldeia um botijão e, assim, se configurou uma terceira casa com possibilidade de cozinhar usando o gás. Ressalto o termo possibilidade, pois mesmo nas residências em que há um fogão funcionando não se deixa completamente de lado a lenha da floresta, quase sempre retirada e trazida pelas mulheres adultas. Não é incomum encontrá-las em trânsito no círculo de Kawerêtxikô, carregando impressionantes fardos de lenha em bem-trançadas cestas de palha nas costas, apoiadas por uma fita na testa. De todo modo, o fogão ocupava um lugar especial dentro da casa de residência. A "cozinha", uma construção independente e menor que a casa, mas feita no mesmo estilo, era reservada apenas para o cozimento com lenha da floresta. Esse tipo de cozimento acabava produzindo, por vezes, muita fumaça. Os funcionários da Funai, segundo Orengô, aconselharam os Tapayúna a cozinhar fora do local de moradia, a fim de evitar os danos que a fumaça poderia provocar, principalmente às crianças. Teve origem, assim, a "cozinha", um empréstimo lingüístico da língua Kaykwakhratxi do Português. Todas as casas de Kawerêtxikô foram, portanto, compostas de ao menos duas estruturas: a casa de residência, onde, por vezes, se encontra o fogão a gás, que não produz fumaça; e a "cozinha", onde, por incrível que pareça, nunca encontraremos um fogão a gás.
} 
A referida rusga se deu após duas semanas de convivência com o técnico. Até então, eu não havia notado nada de particularmente estranho na relação dele com a população de Kawerêtxikô. Ele era uma pessoa atenciosa com os indígenas que buscavam auxílio na farmácia, sabendo, inclusive, várias palavras e expressões em Mebengôkrê - que era a língua que ele pensava ser a língua tradicional dos Tapayúna. Para sua surpresa, eu lhe expliquei que não e que eles falavam uma língua próxima, mas diferente do Mebengôkrê. O plantonista disse que se esforçou para aprender algo do último idioma pois, até onde ele havia notado, as mulheres eram "proibidas" de aprender o Português em todas as aldeias da Terra Indígena Capoto Jarinã. Eu tentei lhe explicar que não era exatamente assim que as coisas aconteciam. Argumentava, para tanto, que as mulheres adultas, em boa parte dos casos, ao menos entendiam o Português, mas, muitas vezes, não se sentiam a vontade para dialogar com alguém estranho nessa língua - ou em qualquer outra diferente de sua língua materna, principalmente com um estranho não-indígena ${ }^{70}$. Contudo, nada conseguiu demovê-lo desse pré-conceito: sempre que entrava uma mulher indígena no posto, ele se dirigia em Português a ela e, como a mesma não respondia, isso era, em sua opinião, prova cabal de que elas não entendiam nada do que estava sendo dito e, portanto, eu estava errado.

Esse técnico, por volta dos 30 anos de idade, estava trabalhando no Distrito Sanitário Especial Indígena Kayapó (DSEI Kayapó) havia quase um ano. Ele era casado, na igreja evangélica, com uma outra técnica em enfermagem, que havia deixado os plantões entre os índios para estudar para um curso superior na mesma área, em uma das cidades do norte do Mato Grosso. Esse era também o plano dele para o médio prazo: economizar algum dinheiro no trabalho com os índios e, depois, conseguir bancar seu curso superior, se juntando à esposa.

Pouco antes do fechamento da farmácia, por volta das $18 \mathrm{~h}$, eu tomava banho e me encaminhava para as reuniões na Casa dos Homens. Quando voltava, uma ou duas horas depois, o posto já estava fechado para atendimentos regulares. Eu e ele, então, tínhamos bastante tempo disponível para jantar, conversar e, por vezes, assistir um filme em meu laptop antes de dormir, caso o mesmo tivesse bateria suficiente. Essa

\footnotetext{
${ }^{70}$ Esse fato pode ser razoavelmente explicado pela noção de que as mulheres são, via de regra, as conservadoras das coisas e dos costumes; aos homens, cabe o papel, idealmente, de criar e/ou 'fagocitar' as novidades (cf. capítulo 3)
} 
dinâmica de ida à Casa dos Homens e volta para a farmácia foi comum a todos os plantões que pude compartilhar com os diversos não-indígenas no posto-de-saúde.

Nessas ocasiões, não era raro receber a visita de algum indígena, ainda que o último não estivesse, necessariamente, em uma emergência médica. Por exemplo, uma senhora tapayúna, tarde da noite, trouxe um de seus filhos para ser tratado na farmácia. A criança tinha dores de barriga e o técnico a medicou com um placebo, já que não poderia dar um vermífugo. Descreverei a receita de placebos e vermífugos mais adiante. Na saída, ela falou calmamente em Mebengôkrê que havia uma cobra na entrada principal da farmácia, apontando, de longe, onde o animal estava. Eu e o plantonista, então, passamos um bom tempo decidindo o que fazer, enquanto a senhora voltava, sem pressa, para o círculo da aldeia. A cobra poderia facilmente adentrar à construção do posto pelas frestas na parede externa do posto (Imagem 03). Lembramos que existia uma enxada dentro da farmácia que era usada, normalmente, pelo Agente Indígena de Saúde (Imagem 03) para capinar o entorno da mesma, evitando que o mato ficasse muito alto.

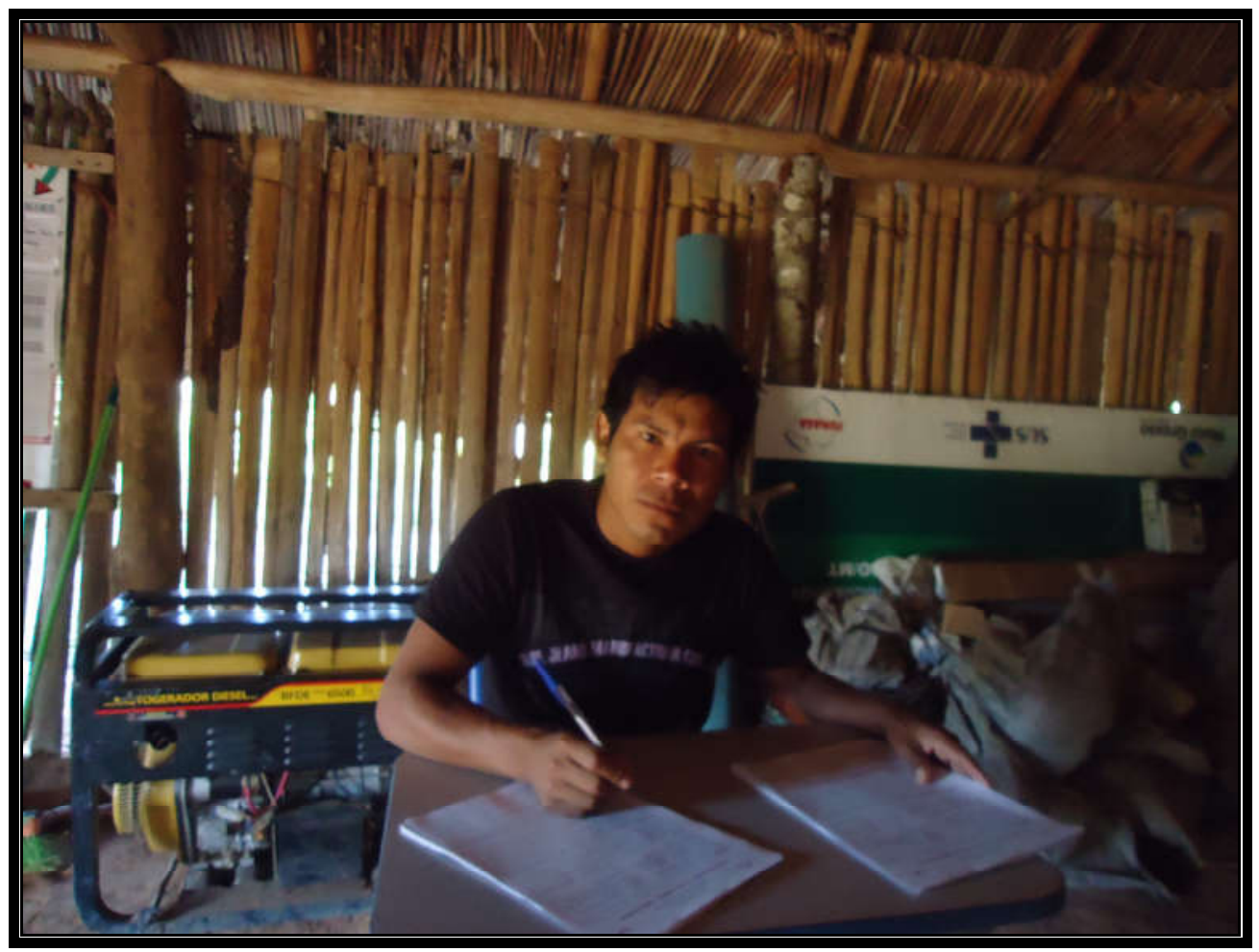

Imagem 03: posto-de-saúde e o Agente Indígena de Saúde de Kawerêtxikô. Nessa ocasião, ele ajudava uma técnica de saúde no preenchimento de algumas guias de atendimento que ela precisava finalizar já no fim de um plantão. Note-se, ao fundo, as paredes laterais da farmácia, feitas de troncos finos ajuntados lado-a-lado. O motor-gerador de energia elétrica, peça preta e amarela entre a parede e 
o técnico, estava sendo usado por uma equipe não-indígena de saneamento que fazia, na ocasião, fumacês na aldeia para diminuir a infestação de mosquitos.

$\mathrm{Eu}$, com menos experiência com a enxada, fiquei responsável por fazer barulho e, com a luz de uma lanterna, atrair a atenção da jararaca para o lado oposto em que o técnico investiria nela com a enxada. Nosso plano funcionou perfeitamente: ele conseguiu, depois de três ou quatro enxadadas, dar cabo da jararaca. Nos foi possível, então, voltar a dormir tranquilamente, ao menos esse dia.

Em outra ocasião, um jovem homem mebengôkrê viria, depois da farmácia fechada para os atendimentos regulares e também depois da reunião na Casa dos Homens, trazer uma de suas filhas para ser medicada pelo técnico não-indígena. A criança apresentava febre que não passava, segundo o jovem mebengôkrê fluente em Português. Enquanto o plantonista auferia a temperatura da menina e lhe dava a medicação, via oral, seu pai conversava conosco. Em dado momento ele comentou o seguinte, aparentemente sem qualquer ímpeto em criticar o trabalho do técnico:

Você precisa ir lá no Bytire e no Kromari [pequenas aldeias mebengôkrê no entorno de Kawerêtxikô], né? Eles lá estão precisando de especialista pra tratar deles. Pode ter gente lá que não tem condição de vir tratar aqui, direto com você. Lá tem pouco medicamento e só tem AIS lá.

O jovem indígena comentava, então, sobre a carência da estrutura de plantão para as pequenas aldeias, que não possuem um técnico plantonista, mas somente um AIS. Nesse momento, o não-indígena parou abruptamente de tratar a garota e se dedicou exclusivamente a responder o jovem mebengôkrê. Visivelmente transtornado, disse ao indígena que sabia muito bem de suas obrigações e que não precisava ser relembrado por ninguém do que deveria ou não fazer. Disse ainda, em tom exasperado, que sua chefe, uma enfermeira não-indígena, estava acompanhando seu trabalho da cidade e que ele, por rádio, prestava contas a ela todos os dias. Assim, argumentava que ali em Kawerêtxikô não havia ninguém que pudesse lhe dizer o que fazer e que sua superior administrativa não morava na aldeia, mas sim em uma das cidades da região. 
O jovem mebengôkrê não se acanhou com a áspera reação do plantonista. Sem alterar o tom de voz, continuou ponderando como se estivesse ainda na conversa despretensiosa anterior:

Olha, tem documento escrito aqui que diz que todos os técnicos precisam visitar lá [as pequenas aldeias]. E o pessoal da aldeia aqui, do Kawerêtxikô, avisa técnico de quando precisa ir lá. A gente tem obrigação de avisar aqui quando precisa de técnico lá nesses lugares. Você ainda não foi lá, né?

O plantonista já estava com o rosto vermelho de raiva. Ele disse novamente que sabia de suas obrigações e que não estava postergando-as. Argumentou, então, que falava diariamente pelo rádio com os AISs do Bytire e do Kromari. Sendo assim, ele sabia que não existia nenhuma emergência, até então, nessas duas localidades, motivo pelo qual ele ainda não havia feito as visitas pessoais.

O mebengôkrê, então, retrucou:

Não é só saber se tem alguém doente pelo rádio. É ir lá ver, conferir, examinar pessoal pra ver se tá tudo bem. Eu já fiz parte do Conselho Distrital de Saúde Indígena [órgão responsável por fiscalizar o serviço prestado no DSEI Kayapó]. Eu também sei o que os técnicos tem que fazer na aldeia.

Nesse momento o plantonista pareceu ter voltado a si. Sem querer delongar a discussão, disse ao homem mebengôkrê que já havia medicado sua filha e que, nos próximos dias, iria tentar fazer as visitas às referidas localidades. Novamente de modo bastante cortês, o indígena agradeceu à atenção do técnico e, como se este último não houvesse nunca se alterado, se despediu dele com um efusivo aperto de mão. $\mathrm{O}$ plantonista fechou a farmácia, eu voltei para minha rede e ele voltou para dentro de sua barraca, armada dentro da edificação da farmácia, no mesmo cômodo da minha rede $^{71}$. Contudo, ele estava ainda bastante exaltado e não conseguiria dormir.

\footnotetext{
${ }^{71}$ Fora a casa do pajé Wotkàtxi, a farmácia era a única construção com divisão interna de cômodos da aldeia Kawerêtxikô. O primeiro cômodo, contíguo à entrada principal do posto-de-saúde, era onde se
} 
Ficamos, então, conversando por algum tempo e aproveitei para explorar qual opinião dele na discussão que acabava de acontecer. Ele me disse que existiam diversos homens indígenas que não sabiam nada de tratamento de saúde e, ainda assim, tentavam dar alguma opinião na ação dos técnicos e outros especialistas. Segundo o plantonista, nenhum desses comentadores ou críticos tinha qualquer formação específica na área de saúde. Ele próprio já havia passado um bom período, inicialmente, em um oneroso curso técnico de enfermagem, após completar seu ensino médio. Depois disso, havia trabalhado em hospitais públicos e particulares da região. Nesses locais, segundo ele, é que se aprendia realmente sobre o tratamento dos corpos humanos, nas emergências em que, muitas vezes, era preciso atender sem a supervisão ou ajuda de um médico, nem mesmo de um enfermeiro. Assim, entre os Tapayúna, percebe-se também a centralidade da noção de improviso que Cristina Dias também encontrou em sua etnografia sobre a saúde alopática entre os Munduruku (Dias da Silva, op. cit.). Nas últimas instituições em que havia trabalhado, o técnico disse que seu salário atrasava sempre, motivo pelo qual ele migrou para a saúde indígena, onde os pagamentos ocorreriam de maneira mais regular. Além disso, o provento recebido era um pouco maior e, por fim, era mais fácil de se economizar algum dinheiro já que, durante o período de plantão, não se gastava com nada além da comida e do gás, já que nenhuma aldeia possuía lojas de comércio de qualquer espécie.

Porém, a grande desvantagem do trabalho nas aldeias era, para ele, a interferência dos não-especialistas indígenas no trabalho dos especialistas nãoindígenas da saúde alopática. Deu como exemplo o jovem mebengôkrê que tinha acabado de tirá-lo do sério. Segundo o plantonista, esse indígena ficava

dava o atendimento ao público, em dois balcões de madeira montados pelos próprios indígenas. Ainda nesse primeiro cômodo eram guardados, num arquivo de aço fechado à chave, a qual sempre estava sob a posse do não-indígena de plantão, o estoque de medicamentos alopáticos, bandagens, linhas para sutura, seringas, um par de auscultadores, envelopes para o preparo de soro para hidratação, entre outros materiais. Em uma prateleira de madeira também montada pelos homens da aldeia, jaziam alguns comprimidos, xaropes e medicamentos de uso mais cotidiano. Na segunda divisão do posto, estava a cozinha. Além de uma pequena mesa de madeira, um fogão/botijão, uma pia improvisada com grandes tambores de plástico e uma prateleira de madeira para se guardar comida, havia uma espécie de tablado, erguido em madeira e cimento, há cerca de 20 centímetros do chão, onde os plantonistas que assim desejassem montavam suas barracas de camping. Quase todos também armavam uma rede, onde ficavam descansando quando a farmácia estava aberta e não havia pacientes a serem atendidos. A divisão era feita com o mesmo material das paredes laterais das casas (Imagem 03), com uma pequena passagem de um cômodo para outro, normalmente coberta por um plástico preto. No caso citado do pajé Wotkà, sua casa possuía apenas uma pequena divisão feita com troncos finos, onde, de dentro, era possível esticar os braços e tocar as duas paredes. Era aí onde ele guardava o material de pajelança (ervas e fumos, basicamente), além de bordunas, arcos e flechas e uma antiga espingarda cartucheira. 
constantemente rondando o posto e se intrometendo em seu trabalho. A discussão descrita aqui teria sido, para o técnico, a "última gota d'água para transbordar o copo". Argumentou, então, que alguns indígenas, por terem participado de "palestras que não valem nada" sobre noções de higiene e a terapêutica da saúde dos corpos, se intrometiam no trabalho de quem teve uma formação de vários meses nos procedimentos dessa mesma área. Ele fazia referência, então, às curtas conferências, normalmente organizadas pelas enfermeiras, visando versar os indígenas em certos temas básicos de higiene e cuidado com o corpo. Completou seu argumento com a frase: "E pior, esse rapaz aí não tem nem mesmo a $8^{a}$ série completa". Antes de dormimos, o técnico me confessou, ainda, que pretendia largar o trabalho na saúde indígena nos próximos meses e entrar em um curso superior de enfermagem.

Quando comparado com o trabalho de outros profissionais na mesma função, a relação que esse plantonista mantinha com os habitantes de Kawerêtxikô pode ser classificada como bastante técnica ou profissional - e, como conseqüência, também mais distanciada do cotidiano de Kawerêtxikô. Assim, apesar de falar e entender algo de Mebengôkrê, ele nunca aceitava qualquer presente dos indígenas. Na verdade, como já visto, seu interesse nessa língua estava diretamente relacionado à sua crença de que as mulheres indígenas eram "proibidas" de aprender o Português - e eram elas que mais frequentemente traziam seus filhos à farmácia. Nem mesmo depois de uma grande pescaria ou caçada de um grande animal, como uma anta, ocasiões em que os homens indígenas voltavam com uma quantidade grande de carne, que precisava ser logo consumida pela falta de refrigeração em Kawerêtxikô, o técnico se recusava a receber algo. Não é preciso dizer que a recusa da troca é, em última instância, uma recusa da aliança e de um relacionamento mais profundo com os indígenas (Mauss, 2003).

Os homens jovens da aldeia tinham uma verdadeira paixão pelo futebol e, diversas vezes, carregavam suas baterias nas placas solares durante todo o dia para assistir duas horas de jogo à noite, ao vivo, na televisão com parabólica existente na casa do cacique Roptyktxi ou do mebengôkrê Txuakrê. Nessas ocasiões, sempre alguém vinha me chamar no posto e, com isso, o convite era estendido a quem estivesse ali de plantão. $\mathrm{O}$ único técnico, entre homens e mulheres, que nunca subiu para o círculo da aldeia e atendeu a um desses convites foi o que participou da discussão descrita acima. Por vezes, eu próprio o chamava para assistir alguma partida 
especial, do time adulto masculino de Kawerêtxikô que recebia outra aldeia em um jogo amistoso ou uma partida interna apostada entre os homens adultos, durante o dia. Ele tão pouco atendia a esses convites e seu argumento era sempre o mesmo: podia acontecer uma emergência de saúde em Kawerêtxikô ou em outra localidade e ele não estar no posto ou conferindo o rádio, para dar o socorro adequado. Sob tal argumento, ele se isolava de qualquer contato mais estreito com o pessoal da aldeia. A negação constante da troca e a recusa em participar de qualquer atividade conjunta com os habitantes de Kawerêtxikô era uma maneira que esse técnico tinha de manter sua especialidade no tratamento alopático isolada da vida cotidiana de Kawerêtxikô. Ele se limitava a aplicar sua técnica a "pacientes" e não procurava relacioná-la, de maneira alguma, com a realidade social dos Tapayúna.

No dia posterior à discussão, coincidentemente ou não, fui chamado pelo técnico para acompanhá-lo a uma visita ao Kromari. Ele encontrou uma adolescente mebengôkrê com fortes dores abdominais, ao ponto dela não conseguir deixar a rede. A garota foi medicada e voltamos para Kawerêtxikô. O técnico comentou comigo que a situação dela não era nenhuma emergência: apenas cólicas pré-menstruais corriqueiras. Depois dessa estada em Kawerêtxikô, eu nunca mais encontraria esse plantonista em campo. Fiquei sabendo, por uma conhecida em comum, que ele havia deixado o trabalho na saúde indígena no início do ano de 2014, tendo sido selecionado em um vestibular para enfermagem na mesma cidade e faculdade em que sua esposa já estudava.

Gostaria de salientar determinados aspectos derivados da situação e contexto dessa rusga. Inicialmente, é fácil notar a importância do ensino formal na construção da autoridade dos não-indígenas envolvidos com a saúde alopática. Há uma espécie de continuum que se inicia com a formação escolar básica, o ensino médio e, por fim, o curso de técnico em enfermagem, que torna aptos os plantonistas a exercerem tal função dentro dos postos-de-saúde nas diversas aldeias da Terra Indígena Capoto Jarinã. Aquilo que o jovem mebengôkrê lembrava que era dever do técnico não era simplesmente algo que este último havia por ventura esquecido ou estava postergando: era uma interpelação que vinha, na visão do plantonista, de alguém que não tinha o mesmo grau de ensino formal que ele próprio, nem no nível básico/médio e muito menos na especialidade terapêutica em que este último era formado - e pela qual estava sendo interpelado. Era, portanto, um questionamento fora do lugar, para o 
plantonista, não apenas por uma falha no argumento do questionador, mas pelo lugar de fala em que o técnico o colocava: uma posição inferior justamente por não possuir o mesmo nível de estudo formal que ele próprio.

Por outro lado, não é difícil notar a irredutibilidade do jovem mebengôkrê frente à tentativa do técnico em desqualificar sua fala. Os indígenas de Kawerêtxikô não se submetem passivamente à tentativa de sujeitá-los à condição de "paciente" ou, no caso acima, de um mero "ignorante" e "acompanhante de paciente". Há um embate-não-resolvido - ou somente resolvido temporariamente, em cada situação específica - entre a submissão ao papel de um corpo inerte a sofrer as intervenções da terapêutica alopática ("paciente"), de um lado, e, por outro lado, a condição ativa de conhecedor de ao menos alguns entremeios dessa mesma terapêutica. É justamente o saber lidar com tais situações que garante a permanência relativamente estável de parte das técnicas de enfermagem com quem tive contato.

Nesse ponto, há aí um problema que nominarei de dupla submissão. Ainda que a Subsecretaria Especial de Saúde Indígena do Ministério da Saúde (Sesai-MS) atenda à população indígena dentro da própria aldeia e que somente em casos considerados mais graves os tratados sejam encaminhados a algum hospital de um centro urbano das imediações, essa tentativa de dupla submissão ainda opera. Defino essa categoria como a prática dos profissionais da medicina não-indígena alopática de tentar submeter seus tratados ao nível de meros "pacientes", os alvos de sua terapêutica na aldeia e, ao mesmo tempo, esses "pacientes" perfazerem uma população historicamente marginalizada nas relações com os não-indígenas de maneira geral, sem estudo formal e, no mínimo, não-completamente-civilizada. Os "pacientes", como o termo deixa claro, não tem qualquer agência positiva no tratamento que será conduzido pela medicina alopática para dar fim ou aplacar seus males. Contudo, principalmente quando freqüentam as cidades do entorno de suas terras indígenas, essa última população sofre também os estigmas típicos do preconceito contra as populações originárias da América: são previamente classificados como preguiçosos, desonestos, bárbaros e, principalmente, avessos às noções básicas de higiene - agora por pessoas que não convivem cotidianamente com eles e que os encontram nas cidades.

Para dar apenas mais um exemplo de dupla submissão dentro de uma miríade que pude etnografar nas relações dos Tapayúna com os não-indígenas, cito 
rapidamente um caso de um gerente de hotel na cidade de Peixoto de Azevedo (MT) que se recusou a hospedar uma família tapayúna que visitava a cidade para tratamento de saúde no hospital local. Era madrugada e o ônibus de linha que atravessava o Parque indígena do Xingu (PIX) havia acabado de chegar em Peixoto. A família viajava com crianças que fariam tratamento de saúde alopático e não queriam ficar na super-lotada Casa do Índio (Casai) ${ }^{72}$ daquela localidade. Sob o argumento de que o cheiro do óleo de pequi usado pelos indígenas incomodava os outros hóspedes, sujava sua roupa de cama e o obrigava a trocá-la praticamente todo dia, o gerente negou hospedagem a essa família. Eles foram para um outro hotel, onde conseguiram, pagando adiantado, se hospedar. O gerente do primeiro hotel me confessaria, mais tarde, que o motivo principal de negar hospedagem aos Tapayúna não era somente 0 cheiro peculiar do óleo de pequi ou a falta de higiene, mas sim o fato dos indígenas em geral serem desonesto e fugirem, por vezes, sorrateiramente do hotel para não pagar a conta.

A reação dos habitantes de Kawerêtxikô frente a essa tentativa de submetê-los duplamente é, de início, ignorar o interpelador. Os Tapayúna se preocupam em manter uma boa relação principalmente com aqueles que são ou podem vir a ser classificados como parentes, sejam co-sanguíneos ou classificatórios. O uso mais genérico de tal categoria é principalmente frente a outros grupos indígenas que não são habitantes da mesma aldeia e/ou da mesma etnia. Pelo que pude perceber, dentro da mesma aldeia ou do mesmo povo, não se fala exatamente em parentes já que tal uso seria potencialmente uma redundância. Aqueles pesquisadores que já tiveram a oportunidade de assistir alguma liderança indígena discursar em determinado congresso ou curso que juntasse vários povos indígenas provavelmente já escutaram esse uso: "os parentes de tal aldeia sofreram a mesma coisa que estou narrando agora"; "os parentes de tal povo também estão presentes aqui na reunião", etc. Contudo, é interessante notar que essa parentela em potencial não costuma abarcar os não-indígenas genericamente tomados. Isto só acontece com não-indígenas individualmente tomados, como um pesquisador que passa meses convivendo na mesma aldeia ou uma funcionária da saúde alopática particularmente bem quista. Nesses últimos casos, os não-indígenas ganham um nome específico em

\footnotetext{
${ }^{72}$ Mais à frente, no item 4.3, irei analisar pontualmente o papel das Casai na terapêutica alopática nas cidades da região.
} 
Kaykwakhratxi e, consequentemente, um conjunto de parentes mais diretos. A relação de parentesco é então mantida a partir, principalmente, das trocas de dádivas e contradádivas, já que os não-indígenas em questão muitas vezes não dominam completamente a língua e os costumes daquele povo que o adota.

Não há dúvidas de que essa é uma maneira peculiar, adaptada, de englobar uma alteridade, como visto no capítulo anterior. Poder-se-ia argumentar, assim, que, na impossibilidade de fazer uma guerra explícita contra os não-indígenas e saírem vitoriosos, os Tapayúna acabaram englobando-os como parentes - ao menos alguns deles, é claro. No entanto, como pondera Marcela Coelho de Souza (2010), em seu estudo específico dos Kinsedje, grupo bastante próximo linguística e culturalmente aos Tapayúna, essa possibilidade de aliança continua permeada por uma constante tensão guerreira, ainda que a guerra em si não seja, sempre, efetivada:

Esse estilo guerreiro se manifesta mesmo ali onde a aliança, e não o confronto, está em jogo: o discurso dirigido a ou sobre o branco aliado é frequentemente marcado pela afirmação de que esta aliança é uma pausa, ou uma exceção, uma concessão quase, no que se compreende e afirma como uma relação global de potencial hostilidade. Assim, a primeira frase que o cacique Kujusi me dirigiu na primeira vez em que conversamos a sós, em um quarto de hospital em Washington, DC, onde ele se tratava de uma pneumonia, foi: "você tem de saber que eu não gosto de brancos." [...] Todas as narrativas sobre a chegada de parceiros não-indígenas se iniciavam com "no início, não gostava/não confiava em Fulano", "não queria Sicrano aqui”. Como disse, isso me inclui. (idem :102)

Assim, o processo de criar parentes que inicialmente eram não-indígenas não é exatamente uma fuga da possibilidade da guerra: os parentes desse tipo são criados a contra-gosto, sempre com a marcação de uma tensão guerreira - isso também entre os Tapayúna. Eu próprio só fui aceito em Kawerêtxikô depois que estava muito bem acertado o papel que eu desempenharia na ajuda aos Tapayúna, como visto na Introdução. No capítulo 2, o imbróglio que envolveu a antropóloga Daniela Batista de 
Lima e eu é mais um exemplo desse princípio combativo. Cabe lembrar que, por vezes, uma guerra efetiva pode ocorrer, com suas mortes, seqüestrados e espólios de guerra, como no caso da tomada da balsa de automóveis e a expulsão dos nãoindígenas da Terra Indígena Capoto Jarinã que também relatei no capítulo 2.

Ainda sobre as mudanças sociais entre os Kinsedje, a autora do mesmo artigo acertadamente assevera que é:

[...] importante compreender que o foco dos esforços assim como dos receios indígenas não está na oposição entre conservação e transformação, tradição e inovação: o risco não é transformar-se, mas transformar-se completa e definitivamente - isto é, dar fim à transformação. (ibid idem :106-107, ênfases do original)

A observação acima é, sem dúvida, também válida para os habitantes de Kawerêtxikô: eles possuem estratégias para efetivar um mínimo de controle deles próprios sobre as mudanças que historicamente lhes acometem. Uma outra coincidência entre o contexto Tapayúna e a realidade analisada por Coelho de Souza é que tanto os Kaykwakhratxi como os Kindsedje estão acossados, em suas guerras de mudança, não só pelos não-indígenas, mas também por outros grupos indígenas com os quais eles mantêm constante contato - no caso dos Tapayúna, os Mebengôkrê e, no caso dos Kinsedje os povos "alto-xinguanos" (ibid idem :100 e subsequentes).

Na discussão descrita, contudo, o jovem homem morador de Kawerêtxikô não ignora o técnico em saúde e efetivamente empreende um debate com ele. No último caso, a família indígena dá as costas para o gerente do hotel e vai procurar um outro lugar onde se hospedar. Penso que essa diferença pode ser inicialmente entendida nos termos dos contextos sociológicos distintos em que os dois exemplos se dão: o primeiro ocorre dentro da Terra Indígena Capoto Jarinã, mais especificamente dentro da aldeia Kawerêtxikô dos Tapayúna. Nessa conjuntura, o jovem homem que discute com o técnico em saúde está, por assim dizer, 'em casa'. Quem está de passagem, cumprindo um plantão ou simplesmente trabalhando é o jovem técnico em enfermagem. A situação se inverte quando pensamos em uma família que tem como residência a aldeia Kawerêtxikô e passa uma temporada na cidade afim de se tratar no hospital: aquela é uma viagem temporária e as relações com os não-indígenas são 
travadas de maneira bastante fugaz, já que não perdurarão no tempo e no espaço comum ou cotidiano daquela família.

Por outro lado, o período de vinte dias mínimos de plantão que os técnicos em enfermagem precisam cumprir nas aldeias da TI Capoto Jarinã não é um tempo exatamente desprezível, do qual poder-se-ia ignorar eficazmente qualquer relação mais íntima com a população local. Deste modo, se hipoteticamente o encontro entre os dois jovens tivesse se dado em uma Casai ou hospital na cidade, é provável que o referido encontro hipotético não tivesse se desenrolado em uma discussão. Do mesmo modo, se a família não estivesse visitando uma cidade, mas alguma aldeia dentro da TI Capoto Jarinã, possivelmente eles não teriam que pagar pela hospedagem e acionariam uma potencial relação de parentesco. Com isso, se levarmos em conta que os técnicos possuem um plantão de 1/1 dia, então, virtualmente, metade da vida deles é dedicada ao atendimento de indígenas em algum posto-de-saúde da região.

Passo agora a descrição do trabalho de outros plantonistas no dia-a-dia de funcionamento do posto-de-saúde em Kawerêtxikô.

\subsection{Falta de higiene, placebo e corpos frágeis: a alopatia em Kawerêtxikô}

Já disse, acima, que as mulheres indígenas eram aquelas pessoas que mais comumente freqüentavam o posto-de-saúde da aldeia. Contudo, normalmente não eram elas as diretamente atendidas pelas plantonistas: o mais comum é que elas estivessem encaminhando uma criança para algum tratamento. Os problemas de saúde mais comuns nas crianças eram relacionados ao trato respiratório, intestinal e de pele. Sobre o primeiro tipo, Orengô Tapayúna me explicou que eles diminuíram bruscamente depois que a queima da lenha para o cozimento de alimentos foi transferida para uma construção independente (cf. nota 71, no presente capítulo). Os problemas de pele, por outro lado, eram comumente tratados sem grandes interferências dos não-indígenas: na maioria dos casos, a técnica em saúde apenas receitava uma pomada, que era aplicada inicialmente no momento da consulta e, depois, a própria mãe ou parente indígena ficava responsável pela reaplicação até os sintomas cessarem. Nesse ponto, a independência entre tratadores e tratados, típica da 
terapêutia alopática, contribuía para uma certa independência das mulheres de Kawerêtxikô frente às técnicas em enfermagem - mas, como veremos, nem sempre esse era o caso.

Havia também um banho com um produto especial para bebês com problemas de pele. Esse banho funcionava nos mesmos moldes que a pomada: a técnica ensinava a mãe a dissolver o produto na água e a passá-lo, evitando partes do corpo mais sensíveis, como os olhos. Depois disso, os banhos diários eram normalmente dados pela mãe ou algum parente. Assim, o que os não-indígenas chamam comumente de “dores de estômago" era uma das causa mais comuns da ida das crianças à farmácia, necessitando de uma intervenção mais complexa das técnicas ou outros profissionais de saúde.

Existiam poucas opções, dadas as possibilidades técnicas e instrumentais das plantonistas, para o tratamento das dores de estômago. A suspeita inicial era sempre que o mal estar estomacal estava sendo causado por uma simples disenteria alimentar ou uma verminose. A medicação, nesse último caso, era tipicamente alopática: havia um conjunto básico de vermífugos que davam conta do escopo quase completo dos agentes causadores desse problema.

Contudo, a administração desse medicamento não é tão simples quanto a aplicação tópica de uma pomada. Isto porque não se pode, segundo as técnicas me informaram, ministrar o lombrigueiro tarde da noite e deixar a criança voltar para casa. Deste modo, de acordo com todas as plantonistas que encontrei, o "paciente" poderia ir dormir e se sufocar com os vermes sob o efeito do remédio, dependendo do grau de infestação. Assim, via de regra, os vermífugos só eram receitados na primeira parte da manhã ou início da tarde, nunca depois desse horário. Algumas horas depois, a plantonista precisava ir à casa da criança para avaliar se estava correndo tudo bem. Todas as doses eram, portanto, diretamente controladas pelas técnicas.

Uma outra possibilidade para as disfunções intestinais das crianças, segundo as técnicas, era a intolerância à lactose. O filho mais novo de Pinkã, um bebê de poucos meses de vida, foi diagnosticado com esse mal. $\mathrm{O}$ tratamento, nesse caso, estava além das possibilidades que a plantonista tinha normalmente a seu dispor. Se algum bebê ou criança mais nova era suspeita dessa intolerância, não restava nada à especialista não-indígena a não ser encaminhá-la para alguma cidade da região. $\mathrm{O}$ recém-nascido de Nokêrê passou alguns dias na Unidade de Tratamento Intensivo 
(UTI) do hospital público de Peixoto de Azevedo durante o ano de 2014. Ele apresentava fortes reações ao leite materno e, assim, estava bastante desnutrido. Seu problema foi parcialmente contornado com a receita, por um médico do hospital, de um leite-em-pó especial. Esse produto, inicialmente ministrado pela técnica em enfermagem, passou gradativamente a ser dado pela própria família do bebê. Ele não constava na lista de medicações normalmente disponível nas farmácias da região da Terra Indígena Capoto Jarinã e foi especialmente adquirido para o tratamento do filho de Nokêrê, única criança a sofrer de tal problema em Kawerêtxikô.

O bebê de Pinkã, mesmo sendo alimentado com o leite especial pela própria família, precisava de acompanhamento exclusivo. Ele era pesado pelas técnicas duas vezes por semana e acompanhado diariamente sobre casos de diarréia para atestar que a desnutrição não voltaria. Além disso, só parte do produto que compunha sua dieta era deixado com os parentes indígenas. A maioria do leite, devido ao seu "alto custo", me explicaria uma técnica, era deixado na farmácia, sob o cuidado das plantonistas, que só repassavam para a família uma pequena parte por vez, somente o necessário para cerca de uma semana de alimentação da criança.

O fato de todas as crianças da aldeia já terem sofrido algum tipo de "dor de barriga" era interpretado pela maioria das plantonistas como prova cabal da falta de higiênica endêmica não só dos Tapayúna, mas de todos os indígenas dessa região. Uma experiente plantonista, senhora separada e com mais de 50 anos e há 5 trabalhando na Terra Indígena Capoto Jarinã, me narrou uma história sobre as crianças panará da aldeia do Nascepotiti que beira a bizarrice. Ela comentou que viu crianças pequenas, de 3 ou 4 anos de idade, brincando no pátio da aldeia, logo após uma chuva. Quando ela se aproximou do grupo, pôde perceber que eles estavam comendo, segundo ela, excrementos de cachorros $^{73}$. Ela fez com que as crianças parassem de comer tal imundice e foi procurar os pais delas para avisá-los do acontecido. Segundo a técnica, nenhum deles deu a menor importância para a grave

\footnotetext{
${ }^{73}$ Os Tapayúna, os Mebengôkrê e os Panará foram introduzidos a esses animais quando estreitaram seus contatos com os não-indígenas. Nas aldeias desses três povos, os cachorros são normalmente tratados de maneira bastante desleixada, beirando a crueldade. Isso, é claro, quando vistos sob a ótica de um não-indígena que tem apresso por tais animais. Os únicos cachorros que possuem uma vida um pouco melhor são aqueles que são treinados para auxiliar as excursões de caça. De todo modo, em Kawerêtxikô e várias outras aldeias há um número consideravelmente grande de cães. Há, inclusive, ações gerais de vacinação de caninos no Distrito Sanitário Especial da região contra raiva, feitas pelo "pessoal da endemia", com os quais tive pouco contato.
} 
notícia que ela trazia. Ela comentava aquilo comigo em segredo e pediu que eu não retomasse esse tema nas conversas com os habitantes de Kawerêtxikô.

Em todo meu período de campo nessa aldeia, eu nunca presenciei algo parecido com o que foi descrito por tal profissional. Não é incomum se ver crianças, mesmo as mais novas, separadas em grupos etários distintos ou, por vezes, quando mais novas, misturados, brincando por toda a extensão da aldeia e seus arredores, inclusive o rio Xingu. Quando o sol começava a se pôr, elas eram chamadas pelos adultos para brincarem mais perto de casa. Em uma determinada reunião na Casa dos Homens, ao entardecer, ouvi os homens gritando para um grupo de crianças préadolescentes que tomava um dos vários caminhos para as roças e, consequentemente, a floresta. Notei que eles disseram a palavra "roptxi", que quer dizer onça em Kaykwakhratxi. Orengô me esclareceu que eles estavam alertando para que elas não fossem muito longe, pois em breve a luz do sol desapareceria e havia o risco de ataque de onças. Do mesmo modo, as mães eram bastante cuidadosas com seus filhos, principalmente os bebês. Ao menor sinal de uma enfermidade, procuravam o posto de saúde ou os serviços do pajé Wotkàtxi - ou, não raro, ambos.

A posição da técnica que me contou o referido acontecido com as crianças da aldeia dos Panará representa um olhar relativamente comum das plantonistas sobre os hábitos higiênicos dos indígenas da região em geral, ainda que não na mesma intensidade extrema. Em uma outra situação, também depois de uma forte chuva, eu comentei com outra técnica em enfermagem que havia tirado uma série de boas fotos das crianças da aldeia brincando na lama que ainda corria. Ela baixou a cabeça e comentou em tom desânimo: "é, agora é só esperar as crises de diarréia pra gente tratar." Essa mesma profissional disse que, no início do seu trabalho, tentava falar com os pais e outros parentes para não deixar as crianças brincarem na enxurrada depois das chuvas. Como, segundo ela, ninguém lhe dava ouvido, gradativamente cessou de fazer tais pedidos.

Não é meu intuito tentar fazer uma exegese de acontecimentos bizarros narrados pelas técnicas no propósito de averiguar ou não se eles são verdadeiros. $\mathrm{O}$ que me interessa, nesse ponto, é marcar que tais relatos extremos tipificam um ideal de indigianidade-como-sinônimo-de-falta-de-higiene, comum nos discursos das plantonistas como também entre aqueles não-indígenas que não estavam diretamente trabalhando com a saúde alopática nas aldeias. Lembro que narrativas do mesmo 
cunho, com crianças novas ou bebês em situações escatológicas, também podem ser encontradas na criação das crianças entre os não-indígenas. Contudo, há de ressaltar que, nesse caso, tais narrativas não corroboram um ideal genérico de pouca higiene ou completa falta dela. Na verdade, entre os não-indígenas, as narrativas dessa categoria são sempre contadas em tom jocoso, ocasião em que é ressaltada uma momentânea falta de atenção da mãe ou outro cuidador, o que levou o bebê ou a criança a cometer o ato de falta de higiene. Não é esse o lugar que essas narrativas ocupam na caracterização dos indígenas. Os vermes não são, por assim dizer, uma característica da infância dos índios ${ }^{74}$ : escutei casos, por exemplo, de jovens indígenas infestados de vermes que, depois de tomar a primeira dose do lombrigueiro, botavam para fora, pela boca, "copos e mais copos de vermes"; ou, então, de um homem indígena adulto que tinha-os caminhando em todos os lugares do corpo, passando inclusive pelos olhos.

É interessante aqui contrapor o contexto de Kawerêtxikô com o estudo feito por Carla Costa Teixeira (2012) sobre a formação de agentes indígenas na área sanitária. A autora nota que os atuais Agentes Indígenas de Saneamento (AISAN) não podem e, portanto, não são ensinados a, por exemplo, fazer construções de quaisquer ordem, como fossa sépticas ou redes de distribuição de água. Os antecessores históricos dos AISANs, os Guardas Sanitários não-indígenas, podiam tanto fazer a manutenção dessas construções como também eram versados na própria montagem das mesmas (idem :577). Deste modo, foca-se a formação atual dos indígenas na "educação higiênica", deixando de lado ações concretas de "engenharia ambiental" (ibid idem :592), as quais os últimos parecem não estar capacitados na visão dos organizadores dessas políticas públicas.

Apesar de basear sua análise em documentos como manuais de formação e não em trabalho de campo com os Aisans, Teixeira acertadamente vislumbra que os indígenas são vistos como "mal cheirosos e sujos, difíceis de lidar (e, do ponto de vista médico, de tratar) e avesso às orientações sanitárias, seja por ignorância, seja por dificuldade de entendimento, ou por serem assim mesmo (por sua natureza ou cultura)." (ibid idem :586). Há somente um Aisan em Kawerêtxikô e ele não tem qualquer formação para a construção, nem mesmo a manutenção, de sistemas de

\footnotetext{
${ }^{74} \mathrm{Ou}$ os indígenas adultos que, nessa visão, se comportam como as crianças não-indígenas. Há um capítulo de As estruturas elementares do parentesco (Lévi-Strauss 1992) sobre como sociedades com tradições de organização social diferentes tendem a se enxergar nas crianças umas das outras: "A ilusão arcaica".
} 
engenharia ambiental relacionados à higiene básica. $\mathrm{Na}$ verdade, até onde eu pude acompanhar, seu papel era o de ajudar o Agente Indígena de Saúde (Ais) da farmácia buscando água em um igarapé próximo, molhando o chão para diminuir a poeira e varrendo periodicamente esse local quando havia uma 'janela' entre os plantões de duas técnicas e o posto-de-saúde ficava temporariamente "descoberto" de nãoindígenas. Na presença das técnicas, esses serviços eram revezados pelo Ais e o Aisan. Há de se notar que tal trabalho de limpeza, nas casas do círculo da aldeia, é típico das mulheres de Kawerêtxikô. O Ais e o Aisan prestam para as plantonistas, portanto, o mesmos serviço que suas esposas fazem em seus lares.

Essa mesma postura, em maior ou menor grau, pode ser notada em boa parte das profissionais da saúde alopática com quem tive contato. É como se as palestras, seminários e outras ações educativas fossem de uma natureza tão básica que até mesmo os indígenas conseguiriam aprendê-las. As organizadoras desses eventos, normalmente as enfermeiras, escolhem um indígena particularmente versado em Português para fazer a tradução das falas das não-indígenas para a língua nativa. Contudo, outras intervenções, como as de engenharia ambiental ou mesmo os meandros da terapêutica alopática propriamente dita, parecem não ser pensadas como afeitas ou ao alcance dos índios - e, como visto, isso se dá por uma falta, gap ou dificuldade que acompanha a própria condição de indígena.

Relembro, nesse ponto, a fala citada por Cristina Dias da Silva (op. cit.) no capítulo 1, em que uma técnica em enfermagem ignora tudo que é traduzido por um Ais Munduruku que fazia a intermediação entre um doente indígena e essa profissional. Se, no tratamento alopático dos "pacientes", a profissional não precisava exatamente saber o que o moribundo tinha a dizer, nas palestras e ações "educativas" das enfermeiras e técnicas, tudo o que era dito precisava, necessariamente, ser traduzido para a língua indígena em questão.

Como os problemas do trato intestinal eram comuns em Kawerêtxikô, a farmácia estava cheia de kits prontos para a preparação rápida do soro caseiro. Esses kits eram pacotes de um pó que, quando dissolvido em água limpa, filtrada e fervida, na quantidade recomendada, dava origem a um soro equivalente àquele advindo da tradicional junção de sal, açúcar e água. Este poderia ser um tratamento inicial para as crianças que apresentavam alguma complicação intestinal, por vezes antes mesmo dos já citados vermífugos. Para os bebês e crianças mais novas, as plantonistas usavam 
uma seringa esterilizada para que as mães administrassem, aos poucos, o soro aos bebês. As crianças mais velhas tomavam o produto em copos retornáveis da própria farmácia.

Essas doses de soro eram os placebos por excelência para combater uma outra característica dos indígenas, quando interpretados pela ótica das plantonistas: a hipocondria generalizada. Segundo as técnicas, as mulheres indígenas, por não falarem bem o Português - ou, por vezes, ignorá-lo propositalmente, como vimos acima - e terem menos contato com os não-indígenas, são aquelas pessoas que apresentam os maiores graus de hipocondria. Assim, uma situação bastante corriqueira nos atendimentos na farmácia era uma mulher indígena chegar com seu filho, tê-lo medicado e, ainda no mesmo dia ou no seguinte, voltar com a criança dizendo que o remédio não teve efeito - um fato que, por si só, mostra que as mulheres indígenas possuem alguma noção de como agem os medicamentos alopáticos. Nesses casos, principalmente quando a medicação administrada anteriormente era um vermífugo, a técnica enchia uma seringa ou copo com soro e dava para a mãe, dizendo que aquilo era uma nova dose do remédio. Algumas mães pareciam acreditar ou então entrar na encenação das plantonistas. Contudo, boa parte delas descarregava o conteúdo da seringa ou do copo no chão do lado de fora da farmácia, devolvia o recipiente, agradecia e ia embora. Não é preciso dizer aqui que tal ato deixava as técnicas em enfermagem particularmente aborrecidas - e que, tal fato, ao mesmo tempo, corrobora a noção básica que as mulheres possuem da agência dos medicamentos alopáticos.

Não há como negar, novamente, que a tentativa de moldar os indígenas como "pacientes" ideais de uma ação de saúde alopática não era sempre bem sucedida. De todo modo, as técnicas não administravam uma nova dose do medicamento pela simples vontade do "paciente" ou seu acompanhante. Estes últimos, ao terem suas pretensões frustradas, não escondiam, por vezes, sua indignação. Havia mães que, em vez de dispensar o placebo do lado de fora da farmácia, apenas o deixam sobre a mesa de atendimento e se retiravam, visivelmente descontentes.

A hipocondria não era a única explicação das plantonistas para negar remédios alopáticos aos habitantes de Kawerêtxikô. Havia um consenso entre elas e outros funcionários de que os indígenas possuíam "corpos frágeis”, que só há pouco tempo haviam tido contato com os não-indígenas e os anti-corpos que esses últimos 
carregavam contra diversas doenças. Essa noção anda junta com a do abuso do uso dos medicamentos: há esse exagero justamente porque os indígenas tem uma sensibilidade maior ao medicamento. Podemos comparar essa noção dos nãoindígenas com a ideia indígena, discutida no capítulo anterior, de que a relação cotidiana com os não-indígenas é que causou aos habitantes de Kawerêtxikô a características de terem corpos mais "moles" ou "fracos" que seus antepassados.

Esse discurso não-indígena tem como base a noção de que os corpos indígenas não são de natureza diferente dos não-indígenas, mas são, por assim dizer, mais sensíveis à medicação alopática em comparação com uma população que tem contato com ela há longa data. Deste modo, as dosagens de boa parte dos remédios eram ministradas em menor quantidade aos habitantes de Kawerêtxikô - ou, em casos especiais, podiam mesmo ser negados inicialmente, até a consulta com uma funcionária mais experiente, como uma técnica mais antiga, uma enfermeira ou um médico.

Essa característica especial dos corpos indígenas, a fragilidade dos mesmos, quando agindo em conjunto com a hipocondria e a falta de higiene que também seria típica deles, fazia com que as plantonistas se arvorassem a ser as protetoras ou 'pedagogas' desses corpos ao mesmo tempo anti-higiênicos, sedentos por medicação e ultra-sensíveis às mesmas. Como bem coloca Cristina Dias da Silva (op. cit.), esse é um exemplo de agência do pólo "cuidar", dentro da típica tensão por ela trabalhada entre "cuidar e administrar". É essa a justificativa dada para se receitar os placebos: como me diria uma antiga e experiente técnica em enfermagem, "uma mentirinha boba, pra que eles não coloquem a saúde deles em risco."

Diferentemente de quando estão na cidade, os habitantes de Kawerêtxikô explicitamente julgam, classificam e interpelam, por vezes diretamente, a ação das técnicas em enfermagem durante a estadia das mesmas na aldeia dos Tapayúna. Há técnicas que são conhecidas como tarimbadas receitadoras de placebos. Tenho conhecimento de famílias que nem ao menos se arvoravam a levar suas crianças ao posto-de-saúde quando tais técnicas estavam de plantão.

Durante o mês de março de 2014, o Agente Indígena de Saúde de Kawerêtxikô passou um abaixo-assinado entre a população adulta da aldeia, tanto homens como mulheres. Todos foram solicitados a assinar um documento escrito que vetava o plantão de uma técnica específica. Ele conseguiu que tal documento chegasse à cidade 
de Peixoto de Azevedo, nas mãos da enfermeira responsável pela alocação das técnicas. Assim, essa profissional da saúde alopática não foi mais mandada à Kawerêtxikô a pedido dos próprios Tapayúna - mas continuou trabalhando em outras aldeias da região.

O motivo para a rejeição dessa técnica em enfermagem não era só o fato dela receitar reiteradamente placebos. Algumas técnicas eram bastante experientes e bemquistas pelos Tapayúna, ainda que, por vezes, elas também receitassem placebos. Além disso, a técnica vetada tinha verdadeiro pavor dos cachorros da aldeia e, por esse motivo, só muito raramente subia ao círculo de Kawerêtxikô para examinar os possíveis doentes. Por fim e mais importante, ela recebeu, pelo rádio do posto-desaúde, a notícia de que sua filha havia brigado na escola da cidade em que estudava. Preocupada com ela e sem a menor possibilidade de lhe prestar algum apoio imediato, a referida técnica chorava quase que diariamente durante seu plantão em Kawerêtxikô. Isto era interpretado, ao menos pelas lideranças masculinas da aldeia, como um sinal de que ela não estava minimamente confortável no trabalho no postode-saúde e, em certo sentido, desdenhando da receptividade das pessoas de Kawerêtxikô, já que o posto pode ser visto como um residência independente, ainda que temporária. Durante todo o resto do ano de 2014 e início de 2015, ela não faria mais qualquer plantão nessa aldeia.

De todo modo, não é incomum que certas técnicas em enfermagem e mesmo enfermeiras formadas sejam tidas como mais bem quistas no trabalho em certas aldeias da região do que em outras. Há técnicas que dizem preferir tirar seus plantões em comunidades menores e mais calmas, como em Kawerêtxikô. Dessa maneira, elas não se sentem tão bem em aldeias mais populosas, como Piaraçu ou Metyktire, ambas com mais que o dobro de habitantes de Kawerêtxikô. Piaraçu ainda tem a desvantagem, para essas profissionais, de ter uma rodovia estadual (MT 322, antiga BR 080) passando bem ao lado da aldeia. Por causa disso, há um incomum afluxo de não-indígenas nesta localidade, principalmente de freteiros e suas caminhonetes $4 \times 4$ prestando serviços ao pessoal da balsa e outros indígenas. Eles trazem e levam pessoas à cidade de São José do Xingu, fazem encomendas e traslados de peças de reposição para a balsa, compram e transportam combustíveis emergenciais para a mesma continuar funcionando, entre outros trabalhos. Nesta última categoria de "outros trabalhos", alguns jovens e adolescentes de Piaraçu encomendam 
sorrateiramente com os freteiros fortes bebidas alcoólicas destiladas. Os nãoindígenas garantem o abastecimento dessas bebidas em Piaraçu por um preço dez vezes maior do que elas são compradas na cidade de São José.

Assim, Piaraçu é uma comunidade menos pacata e muito mais agitada que Kawerêtxikô. Da mesma maneira que isso incomoda certas plantonistas da saúde alopática, outras se adéquam melhor a tal realidade. Um dos fatores preponderantes para determinada profissional da saúde preferir trabalhar em aldeias que possuem uma maior população e, consequentemente, mais doentes, é ter aversão a trabalhar "sozinha". Este último termo foi usado justamente pela técnica que os de Kawerêtxikô haviam vetado. Ela me dizia que, até então, era a primeira vez que trabalhava "sem ninguém, sozinha, só eu por mim mesma aqui nesse fim de mundo.” Como Piaraçu ou Metyktire possuem populações bem acima das de Kawerêtxikô, elas recebem mais de uma técnica em enfermagem. Deste modo, a profissional que ia trabalhar nessas últimas localidades mais populosas sempre possuíam outra não-indígena como companheira. Isto deixa as técnicas em enfermagem, principalmente as mais inexperientes, mais seguras do trabalho que estão fazendo. Este também era o motivo para que a aldeia de Kawerêtxikô quase sempre tivesse plantonistas mais experientes, que travassem relações sociais menos conflituosas com a população local.

Pode-se fazer aqui um paralelo entre a solidão que algumas técnicas dizem existir na relação com os Tapayúna e, ao mesmo tempo, a noção de "vazios populacionais" a que fiz referência durante a descrição da colonização e genocídio do contato entre os Kaykwakhratxi e os não-indígenas, no capítulo 2. É possível, do mesmo modo, extender esse paralelo ao trabalho do antropólogo em campo que, nos primeiros meses, procurava a farmácia para ter companhia de algum não-indígena, como narrado na Introdução.

As três situações parecem negar, de maneiras diferentes, a existência empírica dos Tapayúna. Não estou dizendo, com isso, que plantonistas como essa ou eu próprio negavam o caráter humano, em algum grau, aos indígenas. Como visto no capítulo 1, esta é a premissa básica de agência da alopatia: tratar os males dos corpos humanos. Se houvesse alguma dúvida sobre a humanidade dos corpos dos habitantes de Kawerêtxikô, então a própria terapêutica alopática teria sua eficácia colocada em dúvida. $\mathrm{O}$ que sublinho nesse paralelo é que tal plantonista e o antropólogo não 
consideravam a possibilidade dos Tapayúna serem mais do que simples "pacientes", em um caso, ou mero "nativos", no outro.

Ela e ele não conseguiam enxergá-los como boas pessoas para conversar, para se relacionar (ainda que superficialmente), para, enfim, se viver cotidianamente durante um período determinado de tempo. É claro que isso está relacionado com o fato do não-domínio do Português por boa parte da população de Kawerêtxikô, bem como também a diferente tradição de organização social dos indígenas. Porém, a exemplo de outras técnicas em enfermagem, é plenamente possível traçar relações com os de Kawerêtxikô tomando como base o fato deles poderem ser vistos não apenas como objeto direto de uma terapêutica, mas também como pessoas minimamente interessantes para se relacionar $-\mathrm{e}$ eu próprio pude constatar isso depois dos meses iniciais em campo.

\subsection{As Casais, a comunicação via rádio e os "pacientes" e acompanhantes}

Como já visto, somente uma parte das intervenções terapêuticas não-indígenas aconteciam na aldeia de Kawerêtxikô. Outra parte, tida como mais complexa, era feita nas cidades da região, principalmente em Colider e Peixoto de Azevedo, que possuíam as famosas Casais, as Casas do Índio. O nome oficial dessas instituições é, na verdade, Casa de Apoio à Saúde do Índio. Pude visitar algumas vezes a Casai de Peixoto de Azevedo ${ }^{75}$, que ficava em uma movimentada rua perto do centro dessa última cidade.

A visão inicial foi caótica: dezenas de mães e suas crianças sentadas no chão, com colchões velhos e lençóis, em volta de uma pequena televisão. Ao fundo da sala de entrada, numa mesa com computador e telefone, um guarda não-indígena fazia a segurança do local. Ele logo interpelava qualquer um que não tivesse o fenótipo típico dos índios da região e que adentrasse o Casai. Depois da mesa de recepção desse segurança, havia um pátio interno, onde se vislumbrava, ao fundo, a janela da cozinha. Neste último local eram servidas as três refeições diárias aos indígenas alojados. Virado para o mesmo pátio, havia um conjunto de pequenas salas. Eram

\footnotetext{
${ }^{75}$ Agradeço a enfermeira Mariza Refosco que franqueou minha entrada na Casai de Peixoto.
} 
nesses pequenos quartos sem ventilação que se amontoavam os indígenas quando a Casai fechava e não existia mais a possibilidade de se circular dentro dela ou dela sair.

Em uma de minhas visitas, havia, nesses quartos improvisados e sem janelas, pessoas dormindo em redes e, abaixo delas, mais pessoas alojadas em colchões, lotando completamente cada uma dessas salas. Os alojados mantinham, durante toda a madrugada, as portas abertas para que o ar circulasse no recinto. Além disso, existia um quarto com camas para as técnicas e enfermeiras que estavam de plantão e mais dois quartos para os "pacientes" indígenas que precisassem de isolamento. As plantonistas trabalhavam na sala do rádio amador, onde também havia duas mesas para atendimentos e um armário com medicamentos alopáticos, além de um arquivo de aço com as fichas dos "pacientes". O Casai de Colider, por ficar mais distante do núcleo urbano propriamente dito, além do fato deu não ter um contato mais estreito com seus administradores, não foi visitado em minha pesquisa.

Depois das $22 \mathrm{~h}$, ninguém mais, indígena ou não-indígena, poderia sair ou adentrar o Casai de Peixoto, fora as plantonistas, os casos de chegada de doentes e acompanhantes em carros oficiais ou emergências de saúde. Quem garantia o cumprimento de tal regra era o já citado vigilante, munido de uma arma de fogo de um lado da cintura e cassetete do outro lado. Mais de uma plantonista me relatou que, antes dessa regra, era comum que os homens indígenas se embriagassem na cidade, voltassem tarde da noite para o Casai e atribulassem o sono de outros "pacientes". Eu mesmo já havia acompanhado um homem adulto tapayúna que, depois de jantar comigo em um restaurante de Peixoto, teve que se apressar para não ficar de fora da Casai naquela noite.

Há aqui um outro ponto de embate entre "pacientes" indígenas e profissionais de saúde não-indígena. Uma técnica em saúde me disse que boa parte dos acompanhantes viajava para a cidade não exatamente para acompanhar os parentes que não saberiam, por exemplo, falar bem o Português, mas para "passear, fazer compras e bater perna por aqui [na cidade]". Ela disse que, de início, não autorizava a ida dessas pessoas, que eram sempre homens jovens adultos. Contudo, depois de ter sofrido diversas ameaças, ela passou a ignorar esses casos e encaminhar quem quer que fosse à cidade, inclusive pedindo vôos fretados da empresa de táxi aéreo que prestava serviço para o DSEI Kayapó. Com isso, ela evitava brigas e se mantinha razoavelmente estável no seu emprego. Esses 'falso-acompanhantes' são o motivo 
principal, segundo os diversos profissionais da saúde alopática indígena, para a alta lotação da Casai.

O Casai em Peixoto era mais assiduamente frequentado pelos indígenas que não possuíam nenhuma renda fixa em dinheiro. Os que não se encaixavam nessa categoria, por vezes preferiam pagar um hotel barato em Peixoto do que disputar uma vaga no Casai. Os parentes e amigos que ficavam na aldeia conseguiam efetivamente se comunicar com aqueles que eram temporariamente transferidos para a cidade, "pacientes" ou acompanhantes. Como visto, havia um rádio amador na farmácia da aldeia e, ainda, um outro na casa do cacique Roptyktxi, todos com acesso direto aos rádios das Casais tanto de Peixoto como de Colider.

Pode-se marcar, nesse ponto, uma diferença explícita da maneira como os habitantes de Kawerêtxikô usam os serviços do posto-de-saúde quando comparados ao Munduruku pesquisador por Dias da Silva (op. cit.). Nesse último contexto, a farmácia é vista como um local onde abunda magia, sempre de natureza maligna. $\mathrm{Na}$ aldeia dos Tapayúna, não pude observar nenhum fato que corroborasse uma situação parecida. Na verdade, o local do posto era visitado pelos indígenas de Kawerêtxikô, muitas vezes, sem o intuito de se tratar na terapêutica alopática. Podia-se ir ao posto apenas para conversar ou jogar dominó com uma técnica em enfermagem particularmente bem quista - ou mesmo ajudá-la a preencher fichas, como fica claro na Imagem 03. Por outro lado, também era possível usar o rádio amador da farmácia para falar com parentes ou amigos distantes, em outras aldeias e, como visto, doentes e acompanhantes nas cidades da região. O tema dessas comunicações era, em certas ocasiões, a saúde de algum indígena que fora encaminhado para a cidade - mas não exclusivamente.

Por vezes, se falava pelo rádio temas como a condição de trânsito das estradas locais, a passagem ou não do ônibus de linha, o funcionamento ou não da balsa de automóveis ou apenas se pedia notícias do que estava acontecendo em outra localidade. Eu próprio já presenciei, por exemplo, um jogo de futebol de um campeonato inter-aldeias sendo narrado, na língua Mebengôkrê, em uma faixa específica do radio amador, que não aquela utilizada pela saúde. Vários homens adultos acompanhavam a transmissão, todos dentro da farmácia. Assim, o rádio da farmácia era bastante disputado pois nem sempre o rádio na casa do cacique Roptyktxi estava disponível ou com a bateria carregada. 
Esse rádio era outro motivo de desavença entre indígenas e não-indígenas: até as mais experientes plantonistas pediam que os indígenas não o usassem nos horários reservados para as comunicações referentes à saúde alopática. Nessas ocasiões, as técnicas davam notícia, pelo rádio, dos doentes da aldeia, pediam medicamentos e outros produtos que por ventura estivessem faltando, ficavam sabendo de vôos fretados ou de carros da saúde que estavam em campo, transferindo doentes para a cidade ou recebiam e enviavam radiogramas ${ }^{76}$.

Os ditos "horários da saúde" se conformavam em uma hora pela manhã (1011h) e, também, uma hora no final da tarde (16h-17h). Quando usavam o rádio nesses horários e eram interpelados pelas plantonistas, os índios, na maioria das vezes, o liberavam para as profissionais de saúde. Por vezes, o uso do rádio pelos indígenas, ainda que fora do horário da saúde alopática, era tão intenso que a pequena placa solar que o alimentava não conseguia gerar energia suficiente para que ele funcionasse normalmente na manhã do dia seguinte. Assim, a plantonista ou ficava sem comunicação naquele momento ou, caso tivesse uma boa relação com o pessoal da aldeia, pedia para usar o rádio particular do cacique Roptyktxi. Nunca vi o cacique ou qualquer um dos habitantes de sua casa negar esse tipo de pedido das plantonistas.

Se os que necessitassem de ações terapêuticas mais complexas eram encaminhados às cidades, pode-se dizer também que os especialistas mais completos, com maior conhecimento e potencialmente com maior poder de agência terapêutica frente aos "pacientes" eram, de quando em quando, encaminhados à Kawerêtxikô. Faço referência aqui às periódicas visitas de médicos e dentistas à aldeia dos Tapayúna. Eles eram responsáveis pelos pedidos de exames especiais, como raios-X, tomografias ou ressonâncias. Além disso, receitavam medicações que as enfermeiras ou técnicas em saúde não poderiam oficialmente receitar de forma independente, como alimentos para dietas especiais, remédios para hipertensão e outros fármacos que só eram adquiridos especialmente para "pacientes" específicos, examinados pelos "doutores". De todo modo, se as enfermeiras e técnicas não podiam receitar tais

\footnotetext{
${ }^{76}$ Esses documentos oficiais, recebidos ou enviados pelas técnicas, eram transcritos e arquivados em cada aldeia e, também, nas cidades da região. A transferência de um indígena doente, sem condições de ser tratado em uma aldeia específica e precisando, portanto, de viajar para a cidade de carro ou de avião, era feita através de radiogramas. Esses documentos possuem uma linguagem especial de transmissão, se diferenciando da fala corriqueira pelo rádio. Quando o transmissor, por exemplo, dizia "P.T." na transmissão de um radiograma, isto significava que o recebedor deveria colocar um ponto final na redação daquele radiograma. $O$ documento recebido devia apresentar a mesma redação do documento transmitido.
} 
drogas ou pedir tais exames, eram elas que controlavam a administração regular das medicações especiais, faziam pedidos às cidades quando algum produto desse tipo chegava ao fim e, principalmente, acompanhavam a evolução do quadro de saúde dos "pacientes" medicados - ou, em outros termos, efetivamente administravam o postode-saúde.

Assim, num mesmo dia, os médicos podiam percorrer várias aldeias da região, examinando dezenas de pacientes, levados de porto em porto por um barqueiro mebengôkrê especialmente contratado para esse serviço, todos numa pequena voadeira. É claro que a triagem para o encaminhamento dos casos que deviam ser examinados por esses especialistas também era feito pelas técnicas e enfermeiras locais. Não é difícil notar que essa configuração corrobora sobremaneira o primado dessas profissionais no tratamento cotidiano de saúde alopático oferecidos aos indígenas da região.

No capítulo anterior já fiz menção à experiência traumática que os homens tapayúna passaram quando eram obrigados a estudar regularmente e, portanto, se mudar para as cidades da região. Essa situação se repetia, em menor escala, nas visitas para tratamento de saúde alopático nessas urbes. Contudo, há aqui facetas importantes, que diferenciam as experiências na saúde alopática da educação formal: homens e mulheres, crianças, jovens, adultos e velhos eram encaminhados para o tratamento urbano, enquanto eu só tive notícias de homens jovens que regularmente freqüentaram o ensino formal na cidade. Além disso, no caso da saúde, as idas à cidade eram visitas fugazes e não mudanças por longas temporadas. Deste modo, existia, nessas situações de consultas, exames e passagens momentâneas pelas Casais, uma oportunidade das mulheres e crianças terem contato mais estreito com parte do estilo de vida dos não-indígenas nas cidades - e, é claro, também sofrerem de maneira mais aguda a dupla submissão a que já fiz referência. Ao menos em Kawerêtxikô, não encontrei nenhuma mulher ou criança acima de 2 ou 3 anos que não tivesse ido, algumas ou várias vezes, se tratar na cidade.

Assim, se a Escola Goronã instalada na aldeia dos Tapayúna tem sido uma maneira menos traumática de adquirir certas técnicas e conhecimentos dos nãoindígenas, os encaminhamentos do posto-de-saúde para o tratamento nas cidades é também usado como uma forma controlada de iniciar crianças e mulheres entre os não-indígenas citadinos. 
É claro que os próprios indígenas não se vêem exatamente como portadores de corpos frágeis (no sentido que as técnicas lhes davam), nem tão pouco não-higiênicos e hipocondríacos. Contudo, eles sabem que os não-indígenas, principalmente nos centros urbanos, assim os classificam. Nesse sentido, eles não ignoram a necessidade de versar seus neófitos em uma experiência mais segura e supervisionada entre os não-indígenas. Assim, eles não desejam que seus filhos passem pelas mesmas experiências negativas que eles próprios tiveram nas cidades, como descrito no capítulo anterior.

Por exemplo, o professor Nokêrê Tapayúna me acompanhou em uma de minhas saídas de Kawerêtxiko para a cidade de Peixoto. Nessa ocasião, conseguimos carona em um barco e, mais tarde, em uma caminhonete do DSEI Kayapó. Além de sua esposa, ele levava o seu neto mais novo. Respondendo à minha pergunta se o garoto estava doente, ele disse que não, que o levava nessa ocasião "para ele ir já acostumando com essas viagens pra cidade." Na verdade, nenhum deles precisava de tratamento alopático de saúde na cidade e a viagem tinha o objetivo de adquirir material de pesca e caça em Peixoto de Azevedo e Guarantã. Com isso, as viagens à cidade não tem sempre o objetivo especifico de um tratamento de saúde ou a uma exigência burocrática ligada à educação formal, por exemplo. Os Tapayuna procuram, aos poucos, familiarizar suas crianças com o mundo urbano dos não-indígenas, de forma supervisionada e controlada.

No próximo tópico, tratarei de maneira mais sistemática das terapêuticas indígenas com as quais tive contato.

\subsection{Uma visão geral da terapêutica indígena contraposta à alopatia}

Não tenho condições, com os dados que recolhi, de fazer uma apresentação pormenorizada do sistema terapêutico dos Tapayúna de Kawerêtxikô. Contudo, tenho elementos que mostram os princípios gerais que regem o funcionamento desse sistema entre os indígenas da Terra Indígena Capoto Jarinã e que evidenciam como ele se diferencia da alopatia não-indígena. A descrição que se segue, então, não é uma 
tentativa de etnografar pontualmente a terapêutica indígena, mas visa simplesmente mostrar como a mesma acaba se contrapondo à alopatia moderna.

Durante meu período em campo, pude participar de uma reunião de artesãos indígenas na aldeia mebengôkrê de Piaraçu. $\mathrm{O}$ evento foi organizado pelo Instituto Raoni. Essa instituição tinha um projeto que visava ensinar os artesãos indígenas da região a colocar preço nos produtos que faziam para vender aos não-indígenas. Para tanto, o Instituto contratou uma jovem mulher não-indígena, formada em administração de empresas e com larga experiência em assessorar indígenas nessa situação. Durante três dias, ela e uma secretaria não-indígena do Instituto ensinaram artesãos Tapayúna, Mebengôkrê, Panará e Yudjá, homens e mulheres, a cotar redes, bordunas, peças de cestaria, cerâmica, esteiras, pilões, entre outros materiais, em reais. O norte do evento era habilitar os artesãos a contabilizar a importância em dinheiro da matéria prima do artesanato indígena e, principalmente, as horas de trabalho e o material gastos para produzir uma peça.

Conheci, no alojamento masculino para os artesãos do evento, um senhor mebengôkrê de cerca de 60 ou 65 anos, famoso pajé em toda a região. Um dos meus acompanhantes de Kawerêtxikô comentou comigo que tal pajé havia curado um de seus filhos de uma mazela na perna que os médicos não-indígenas diziam não ser tratável. A cura se deu a partir de diversas sessões de cânticos e baforações de fumaça. Em uma roda de conversa entre eu mesmo e vários indígenas que tomavam parte no curso, esse renomado curandeiro se gabava de ter livrado uma aldeia yudjá inteira de uma espécie de maldição. Ele residira nessa localidade durante algumas semanas e, depois do tratamento, que incluía longos períodos de transes do pajé, os moradores da aldeia yudjá pararam de ser acometidos por constantes picadas de cobra, ataques de porcos do mato nas roças, acidentes em pescarias e outros tipos de infortúnios que lhes atormentavam a vida cotidiana. Ele cobrou dos Yudjá cinco mil reais pela terapêutica e justificou esse alto preço com o argumento de que o mal que ele havia retirado da aldeia estava agora nele próprio. Ele teria, assim, que iniciar uma sessão de cura para ele mesmo depois do tratamento feito para os Yudjá.

Esse senhor trazia para o curso um bonito banco feito por ele em forma de uma anta, ricamente talhado em madeira. Era uma encomenda mediada pelo Instituto Raoni para um não-indígena estrangeiro. No segundo dia do evento, esse banco sumiu do alojamento. O pajé, então, falou em Mebengôkrê no centro de Piaraçu que sabia 
onde estava o banco de anta, mas que não iria entrar na casa do furtador pois sua simples presença poderia matá-lo e trazer outros males à família deste último, ainda que o pajé não desejasse isso. Algumas horas depois, o banco apareceu, mas com as pernas dianteiras da anta quebradas. O trabalho de várias semanas do artesão-pajé havia sido perdido. Ele reclamou, então, como cacique de Piaraçu, Bêdjai, que o autorizou a retirar dinheiro da balsa, na cota de Piaraçu, para que o banco fosse pago (cf. capítulo 2). O preço combinado com o estrangeiro não-indígena era de mil reais e era essa quantia que o artesão-pajé poderia retirar na balsa.

Em Kawerêtxikô, pude acompanhar algumas situações em que os serviços do wajanga ou pajé Wòtkatxi foram requisitados. Quando a irmã mais velha do Ais, em uma madrugada, sentiu as dores do parto mas não conseguia dar a luz, Wòtkatxi foi chamado, junto com a técnica em saúde, para tratar da parturiente. Enquanto a plantonista tirava a pressão arterial dessa jovem, de um lado, de outro o pajé de Kawerêtxikô cantava e baforava um grosso charuto, feito com uma erva especial, por todo o corpo da mulher indígena. Como nem a terapêutica indígena como a nãoindígena surtiram efeito imediato, decidiu-se levar a parturiente de barco para Piaraçu, onde estava residindo um casal de médicos cubanos. A plantonista e o wajanga também acompanharam a grávida no barco. Contudo, ela deu a luz alguns minutos depois da partida da embarcação que voltou, então, para Kawerêtxikô. A técnica em enfermagem pesava o saudável bebê enquanto Wòtkatxi ainda tratava a mãe com o referido charuto.

Em outra ocasião, em uma reunião na Casa dos Homens, encontrei um jovem homem tapayúna, não casado, com as pernas todas arranhadas, de onde pingava, ainda, sangue. Ele me explicou que havia ele mesmo feito aquelas incisões para que o "sangue velho saia e faça mais sangue novo. A gente faz isso pra ficar mais forte". As ranhuras haviam sido feitas com os dentes do peixe-cachorra, um tradicional pescado da região. Um outro jovem comentou que eu deveria fazer o mesmo, visando resultados parecidos. Eu recusei efusivamente o pedido, motivo pelo qual todos os homens presentes naquela ocasião riram da minha falta de coragem.

Até onde pude perceber, essas incisões só eram realizadas quando não havia ninguém adoentado entre os parentes co-sanguíneos. Quando havia algum doente, ainda que em outra localidade, toda a família extensa deixava, por exemplo, de comer carne de "bichos com muito sangue", como tentava me explicar Txuakrê Metyktire 
em certa ocasião em que the ofereci um pedaço de porco frito e ele recusou, argumentando que tinha um sobrinho doente na aldeia do Metyktire. Não se renovava também o sangue no sentido que descrevi acima. $\mathrm{O}$ contato direto ou a ingestão da carne de animais como porcos do mato, antas, capivaras, peixes de grande porte, entre outros, pode piorar a situação do parente adoentado, pois "o sangue do bicho se mistura com o sangue do doente e piora a doença", segundo Txuakrê. A dieta é seguida à risca até que o doente, ainda que residente em outra aldeia, comece a sarar. Assim, quando há sinal de algum apuramento significativo no quadro de saúde do doente, a dieta é gradualmente suspensa.

Um último evento pode ajudar a entender melhor os princípios básicos da terapêutica que perpassa vários povos indígenas da região Capoto Jarinã. O cacique Roptyktxi foi picado no pé por uma cobra venenosa, possivelmente uma jararaca, enquanto trabalhava na sua roça. As roças são espaços somente parcialmente limpos da floresta, onde porcos do mato, cobras, veados e até mesmo onças podem estar de passagem. Ele conseguiu, com bastante esforço, voltar para o círculo da aldeia. Sua esposa, então, chamou Wotkàtxi, que iniciou um cântico visando a melhora do cacique, que não conseguia ficar de pé e estava deitado em uma rede de sua própria casa, sentido fortes dores. Uma das filhas de Ropyktxi chamou também a técnica indígena que estava de plantão naquela ocasião.

Enquanto a esposa de Roptyktxi passava as cinzas da pata de um pequeno pássaro no local da picada, assessorada de perto pelo wajanga tapayúna, a plantonista administrava uma alta dose de um remédio, via oral, para aplacar a dor. Depois que a técnica em enfermagem mediu a pressão arterial de Roptyktxi, que estava, segundo ela, altíssima, a plantonista conseguiu convencer os indígenas que acudiam o cacique a fazer a limpeza do local da ferida - o mesmo local onde, minutos antes, a esposa do moribundo passava as cinzas. Ela pediu ao Ais que buscasse soro, álcool e bandagens na farmácia. Quando o jovem voltou com o material solicitado, ele havia errado o tipo de soro: em vez de soro normal, havia trazido soro glicosado. A técnica estava visivelmente muito nervosa e ela própria foi, correndo, ao posto pegar o soro correto.

Durante todo esse dia e a manhã do dia seguinte, a plantonista tentava convencer Roptyktxi e seus familiares a encaminhá-lo, de avião, para se tratar na cidade. Nesse período, Wotkàtxi o tratava com baforações de charuto e cânticos. A plantonista não podia fazer mais nada além de aplacar a dor do cacique, já que não 
dispunha de soro antiofídico na farmácia. Kawerêtxikô não tinha pista de pouso e, caso aceitasse ser transferido, Roptyktxi teria que viajar, de barco, para a aldeia mebengôkrê do Metyktire e, de lá, esperar o vôo para a cidade. Como o tratamento indígena capitaneado pelo wajanga Wotkàtxi não surtia efeito, Roptyktxi acabou aceitando ir para o Metyktire.

Contudo, uma vez na aldeia dos Mebengôkrê, ele não aceitou imediatamente que a plantonista fizesse o pedido do avião. Preferiu, antes, se tratar com o pajé daquela localidade - para o desespero completo das três plantonistas, uma de Kawerêtxikô e duas do Metyktire, que o acompanhavam. Só depois da tentativa nãoexitosa dessa última terapia foi que Roptyktxi consentiu em viajar de avião para uma cidade da região, onde seria medicado com soro antiofídico. Uma semana depois, ele estava de volta à Kawerêtxikô, quase completamente recuperado.

É possível notar, em todos esses exemplos, que a terapêutica indígena se diferencia sobremaneira da não-indígena alopática. Enquanto a alopatia tem como premissa básica a independência de tratados e tratadores, classificando os primeiros como "pacientes" e lhes ministrado substâncias que causarão uma reação contrária aos sintomas da morbidez, a última tenta acionar uma rede de relações sociais visando sanar ou aplacar a condição do moribundo. A origem da debilidade do corpo humano, para a saúde alopática, esta em uma disfunção restrita a esse próprio corpo, individualmente tomado. Por outro lado, a origem ou ao menos as conseqüências mais diretas das enfermidades indígenas têm resultado e, portanto, são combatidas também fora do corpo, nos interstícios e relações entre diversos corpos, ainda que os mesmos estejam geograficamente separados por uma grande distância.

O que faz os Tapayúna, entre outros povos da região, identificar que estão doentes ou sofrendo de alguma anomalia é, pelo que pude apurar, sempre a deterioração de uma determinada relação. Por exemplo, uma "doença de índio" muito comum na região é o fato de se começar a ver os parentes mortos vagando pela aldeia, nas roças ou na floresta. Se a pessoa que os enxergam não é um wajanga ou pajé, então há algo de muito errado com ela, do ponto de vista dos indígenas. Ela precisa, nesse caso, se tratar com um especialista indígena. Essa típica "doença de índio", me explicaria Wotkàtxi a partir da tradução de Orengô, tem origem, possivelmente, no não cumprimento de determinados ritos funerários específicos, o que fez com que a relação entre os parentes vivos e os parentes mortos se deteriorasse. A consequência 
direta da degeneração da relação é que os vivos começam a enxergar constantemente os parentes mortos.

Em outras palavras, os corpos, no tratamento indígena, se afetam mutuamente. Não seria exagero classificar o princípio de agência dessa última terapêutica como relacional, enquanto a outra tem como base a substancialização e se faz, portanto, em uma abordagem cujos princípios são premissas absolutas. Como levantado no breve histórico do capítulo 1, a medicina alopática unificou os corpos e, a partir daí, tentou descrever como eles reagem ao contato de diversas substâncias. A terapêutica indígena parece ter feito praticamente o contrário: ela conectou os corpos com outros corpos de origem diversas e, a partir primordialmente dessas relações, tentou aplacar seus males ou curar seus problemas.

É a agência desse último princípio que explica, por exemplo, o fato de Txuakrê não poder comer determinado tipo de carne enquanto seu sobrinho, que está a centenas de quilômetros de distância, está doente. Penso ser, por outro lado, a confiança na agência absoluta do soro anti-ofídico o motivo principal do desespero das técnicas em enfermagem na tentativa de levar o cacique Roptyktxi o mais rápido possível para cidade, por exemplo - e, sem dúvida, a descrença completa das mesmas na terapia indígena. Assim, o famoso pajé que encontrei em Piaraçu também poderia, ainda que inconscientemente, afetar negativamente o corpo daquele que havia furtado seu banco - podendo, inclusive, causar sua morte ou de outros familiares.

Do mesmo modo, a explanação também ajuda a entender o fato dos indígenas aceitarem sem maiores problemas a terapêutica alopática, ainda que sem a convicção absoluta que as técnicas em enfermagem e outros não-indígenas nela colocam. $\mathrm{Na}$ visão indígena, o contato com uma alteridade radicalmente diferente faz com que os corpos, já múltiplos e intercambiáveis, fossem afetados pelos corpos dos novos humanos: os não-indígenas. Não é de se espantar, nesse caso, que a alopatia funcione também para os índios e que estes últimos depositem nela alguma confiança. Na falta de uma expressão melhor, o contato com os não-indígenas foi 'interpretado' na soma de mais uma alteridade, dentro da cosmologia indígena. Porém, o mesmo contato, agora na visão dos não-indígenas, é largamente entendido como uma relação entre seres que já possuíam, de antemão, uma mesma essência, uma mesma estrutura geral, uma mesma humanidade - ainda que este fato fosse ignorado pelos indígenas. Em 
certo sentido, esses corpos com a mesma estrutura geral não podem se afetar mutuamente justamente porque eles já são, de antemão, os mesmos.

Além disso, enquanto os corpos únicos tratados pela alopatia podem ter características não-estruturais diferentes, uns sendo mais sensíveis aos medicamentos do que outros, por exemplo, os múltiplos corpos indígenas são, fisicamente, diferentes, mas comungam, por assim dizer, de uma potencialidade de afetamento múltiplo. Os Panará, por exemplo, não comem carne de jacaré pois acreditam que os velhos, quando morrem, se transmutam nesses últimos animais. Os jacarés não possuem mais o corpo humano, mas comungam de alguma humanidade com os Panará vivos justamente porque a forma anterior de seus corpos era a mesma dos Panará, além do fato deles terem convivido conjuntamente e, portanto, se aparentado.

Do mesmo modo, é possível explicar também a diferença de estruturas entre a Escola Goronã e o posto-de-saúde. A primeira não apresentava nenhuma divisão interna, uma sala ou recinto especialmente reservado para os funcionários da educação, como havia na farmácia. A Escola, como visto, era um local, por assim dizer, de passagem tanto de professores quanto de estudantes indígenas, cada um deles com sua própria casa de residência dentro do círculo da aldeia Kawerêtxikô. Enquanto isso, a farmácia pode ser entendida como o local de moradia, por algumas semanas, das técnicas em enfermagem não-indígenas e do antropólogo por um período um pouco maior que as plantonistas. Portanto, o posto-de-saúde ficou sendo, para os indígenas, uma espécie de casa independente, participando, como já dito, de redes de troca, mas não diretamente habitada e, o mais importante, não diretamente administrada por indígenas. A Escola, por outro lado, era um lugar frequentado quase que exclusivamente pelos moradores de Kawerêtxikô - mas por nenhum deles de maneira parcialmente definitiva, como no caso da farmácia para as plantonistas nãoindígenas ou o antropólogo em campo.

Por fim, como o tratamento indígena precisa, necessariamente, agir em uma complexa cadeia de relações entre os corpos e, além disso, tais corpos não são pensados de maneira inerte e isolada, mas sim consciente e ativamente, essa terapêutica é, necessariamente, menos automatizada ou célere que o tratamento da medicina alopática, que pode produzir resultados mais imediatos. Isto ajuda a entender o motivo pelo qual, por exemplo, o cacique Roptyktxi tentava delongar sua permanência dentro da TI Capoto Jarinã, usando, inclusive, os serviços de dois xamãs 
diferentes. Do mesmo modo, isto explica a desculpa do uso de placebos ou a certezaquase-cega das plantonistas na administração dos medicamentos e, como visto, a futilidade ou não necessidade de se usar de traduções, falas, conversas ou outros expedientes comunicativos na terapêutica alopática. $\mathrm{O}$ que há de se falar para alguém que já conhece aquilo que pode ser dito sobre aquele corpo que ela está tratando? Mais que isso, o que pode dizer de proveitoso uma pessoa duplamente submetida, inicialmente como um "paciente" tradicional e, mais que isso, como um nãocivilizado pontualmente avesso às noções mais básicas de higiene?

Finalizo, com isso, a descrição e análise das ações da saúde alopática entre os Tapayúna. A comparação entre a educação formal e a saúde alopática na aldeia Kawerêtxikô será refinada na conclusão da presente tese. 


\section{Conclusão}

$\mathrm{Na}$ tentativa de entender como os Kaykwakhratxi se relacionam com a saúde alopática e a educação formal, uma chave explicativa clara, para um não-indígena, é que a primeira pode ser classificada no que classicamente costumou-se chamar, na antropologia social, de 'esfera da cultura', enquanto a última poderia ser efetivamente situada na 'esfera da natureza'. Assim, enquanto os Tapayúna teriam um poder de agência e administração direta maior no campo da educação formal, efetivamente 'indigianizando' essa área com aulas em língua nativa e toda uma organização bastante diferente da escola não-indígena, na outra seara, a da terapêutica dos corpos, essa liberdade teria que ser necessariamente menor pois se estaria lidando, então, com os imponderáveis de uma única natureza, abarcadora de indígenas e não-indígenas. Foi exatamente desse tipo de interpretação que tentei evitar e me distanciar na descrição e análise da minha experiência entre os Tapayúna nas páginas anteriores.

Deixo claro, portanto, que se existem somente não-indígenas nos cargos administrativos e operacionais dentro da área da saúde alopática, isso não se deve ao fato dos não-indígenas possuírem um conhecimento maior de uma 'natureza humana' do que os indígenas - ainda que tal resposta possa ser a resposta padrão de, por exemplo, uma técnica em enfermagem. Esse discurso é uma alegoria parcial, assimétrica e etnocêntrica das relações que se dão entre indígenas e não-indígenas no contexto estudado. Na verdade, essa constatação diz mais sobre o funcionamento da terapêutica não-indígena como um todo, seu modo de operação e construção de suas hierarquias, do que das relações sociológicas em jogo.

Poder-se-ia dizer, por outro lado, que a relativa liberdade que os habitantes de Kawerêtxikô possuem na gerência da Escola Goronã pode estar mais relacionada com o papel marginal que a instituição escolar possui dentro das políticas públicas do Estado brasileiro do que, por outro lado, da visão de mundo nativa e da 'fagocitação' que os indígenas fazem de conhecimentos, técnicas e instituições não-indígenas. Concordando com este último ponto, ressalto apenas que o peso maior, porque imposto coercitivamente, de uma tradição de longa duração, colonizadora e assimilacionista, pode ter resultados interessantes quando em contato e 'temperada' por uma diferente tradição de organização social, ainda que esta última seja 
classificada como 'simples', 'fria', 'menor' ou 'não-civilizada'. Este é o caso quando há a possibilidade, ainda que mínima, de alguma agência específica das populações que são interpeladas como objeto da ação colonizadora estatal. Tal fato deve ser digno de nota e análise, inclusive se tal 'tempero' se dá, entre outras causas, pela pouca preocupação que o ensino formal público de qualidade pode ter na configuração do Estado atualmente no Brasil. De todo modo, penso ter deixado claro que nessa última área há maiores possibilidades de reinterpretação da tradição colonizadora do que na saúde alopática, que advém, como visto, da mesma tradição colonial e colonizadora.

Assim, tentar entender as relações sociais nessas duas áreas partindo do pressuposto humanista de que compartilhamos todos, indígenas e não-indígenas, uma única e mesma estrutura corporal é reduzir a visão dos habitantes de Kawerêtxikô com quem convivi durante meses como, necessariamente, ilusória ou em algum grau deturpada. Assim, um dos nortes do trabalho que se seguiu foi mostrar que o postode-saúde é tão social quanto a Escola Goronã. Contudo, a sociabilidade ou relações, nesta última instituição, estão diretamente subordinadas a um paradigma não-indígena de funcionamento: o da alopatia moderna. Nesse campo, como visto, há pouquíssimas chances de contra-interpelações que efetivamente mudem a configuração geral das relações sociais de maneira mais duradoura. Reitero que esta subordinação se mostra mais forte ou 'engessada' do que as potenciais relações que podem ser traçadas com os não-indígenas a partir da Escola Goronã.

Partindo de outra chave interpretativa, poderíamos explicar essas diferenças baseados na noção de que a natureza, para os indígenas, é múltipla, enquanto a sociedade ou a potencialidade de sociedade é única e genérica. Nos aproximaríamos, nesse ponto, da tradição interpretativa do perspectivismo ameríndio, onde todos os seres são potencialmente sociais, compartilhando um fundo sociológico comum, mas se apresentam no mundo a partir de naturezas distintas, na visão indígena. Como exemplo, a onça se mostraria em uma natureza de onça, mas ela seria, no fundo, tão social quanto os indígenas ou não-indígenas, podendo efetivamente se comunicar com e interpelar esses últimos. Essas relações, contudo, não estariam diretamente disponíveis a todos aqueles que se apresentam na 'roupagem' humana, mas somente para alguns deles em especial: seria preciso a mediação dos xamãs ou pajés (Viveiros de Castro, 2002). 
Não foi essa postura interpretativa que explicitamente adotei, apesar de meus dados de campo se adaptarem bastante facilmente a ela. O principal motivo da nãoadoção explícita do perspectivismo ameríndio foi bastante simples: meu conhecimento do Kaykwakhratxi e do Mebengôkrê é, até o presente momento, bastante precário. Assim, como dizer qual seria, de fato, os princípios cosmológicos ou ontológicos de um povo quando o pesquisador só entende rudimentos daquilo que é dito por eles em sua(s) língua(s) materna(s)? Não seria razoável tentar tecer comentários mais profundos sobre esse tema, dado o presente momento de minha pesquisa. Assim, por exemplo, a única maneira que me foi possível descrever a terapêutica dos Tapayúna foi como ela foi brevemente apresentada no último capítulo: algumas digressões iniciais contra-postas às certas características da alopatia, necessariamente. Deste modo, as lacunas do trabalho de campo se refletem diretamente nas lacunas do texto que agora apresento.

Com isso, gostaria de deixar claro que a escolha de estudar as instituições estatais permanentemente instaladas na aldeia Kawerêtxikô, comparando o modo como os Kaykwakhratxi se relacionam com elas, não se deu por desconhecimento de teorias que tratassem da ontologia indígena. Nem tão pouco per pensar que seria impossível um recorte teórico-metodológico que tratasse da cosmologia nativa de maneira mais densa. A minha escolha se deu, na verdade, pelas possibilidades que a realidade do trabalho de campo me proporcionou: um jovem homem, pesquisador não-indígena, falante de Português e, no fim do tempo de pesquisa, conseguindo aprender apenas as noções mais básicas das duas línguas indígenas mais faladas na aldeia que pesquisou.

Sobre esse ponto, ressalto ainda que a constante tensão guerreira, discutida no capítulo anterior, fazia com que eu não pudesse me dedicar exclusivamente ao idioma Mebengôkrê, nem ao Kaykwakhratxi. Fui corrigido várias vezes por homens e mulheres falantes do Kawkwakhratxi quando eu usava o Mebengôkrê dentro de uma conversa que estava acontecendo em Kaykwakhratxi. O contrário, ou seja, uma interpelação enquanto eu falava a última língua no contexto da primeira, nunca aconteceu nos 13 meses de trabalho de campo não consecutivos em Kawerêtxikô, o que ressalta o caráter franco, entre os indígenas da região, do Mebengôkrê. Nokêrê, uma influente liderança política de Kawerêtxikô, me disse, em uma dessas ocasiões de interpelação por falar o Mebengôkrê em situações em que eu deveria estar falando o 
Kaykwakhratxi, em tom jocoso: "não é pra aprender a língua dos Kayapó, não. É só pra aprender a língua dos Tapayúna." As duas línguas, como visto, possuem o mesmo tronco e família linguística, o que tornava bastante difícil diferenciar as expressões de cada uma delas nos primeiros meses de campo.

Recordo, ainda, que o Mebengôkrê é a língua franca da região. Deste modo, na convivência cotidiana na aldeia, levou certo tempo até eu conseguir mapear eficazmente as pessoas com quem eu devia falar tal ou qual idioma. Nesse interregno, eu preferia usar o Português, com receio de cometer mais deslizes do que eu já cometia até então. Só nos dois ou três últimos meses comecei a conseguir distinguir as duas línguas indígenas.

Tenho consciência, do mesmo modo, que as descrições e reflexões que acabaram de ser apresentadas nesta tese carecem de uma discussão mais detida com a etnologia brasileira como um todo. Considerando a amplitude da literatura, optei por fazer um recorte de textos que dialogavam diretamente com as temáticas da minha pesquisa.

Diante da constatação de que os habitantes de Kawerêtxikô não ocupam cargos de relevância no sistema de tratamento da saúde alopática em Kawerêtxikô, poderia-se argumentar de que há homens na aldeia que são Agentes Indígenas de Saúde (Ais) e Agentes Indígenas de Saneamento (Aisan). No entanto, a existência desses cargos não contradiz os meus argumentos pelas seguintes razões. Primeiro, como visto a partir do seminal artigo de Carla Costa Teixeira discutido no último capítulo 4 (Teixeira, 2012), tanto os Aisan tratados pela autora como os Ais com quem tive contato na Terra Indígena Capoto Jarinã não possuem, como funções regulares, o controle na distribuição dos medicamentos alopáticos, nem qualquer função relevante na administração geral da farmácia, mesmo na área de engenharia do saneamento. Eles fazem trabalhos marginais na terapêutica alopática: levar água potável ao posto-de-saúde quando ainda não se tinha torneiras; molhar o chão do mesmo para aplacar o poeira na época da seca; buscar medicamentos para a técnica em enfermagem que está tratando alguém; fazer a tradução para a população da aldeia das palestras das enfermeiras, entre outras funções. O Ais de Kawerêtxikô preenchia, como visto na Imagem 03, certas fichas de atendimento no plantão de uma técnica particularmente bem quista. Ele ajudava, nessa ocasião específica, essa técnica determinada num trabalho do pólo "administrar" ressaltado por Cristiana Dias da 
Silva (Silvia, 2010). Contudo, isto não era uma função comum deste Ais e ele não fazia isso para qualquer profissional da saúde que estivesse trabalhando na aldeia. De todo modo, isso mostra que, mesmo sem o curso formal de técnico em enfermagem, esse indígena era capaz de, efetivamente, fazer parte do trabalho das técnicas.

Em segundo lugar, se comparamos com a Escola Goronã, dizer que os Kaykwkhratxi efetivamente gerenciam o posto seria como afirmar que eles administram efetivamente a Escola sem ter, por exemplo, controle direto sobre os cargos de coordenador pedagógico, diretor e professores. Isto seria um absurdo. Se a Escola Goronã fosse um "anexo" de alguma outra escola da região, então os Tapayúna não a administrariam, não estariam controlando os cargos supra-citados e estariam sujeitos, nessa potencial situação, a um controle externo, seja de um grupo indígena de outra localidade ou da burocracia não-indígena.

Por fim, há ainda dois pontos em aberto que não tratei sistematicamente na comparação entre a Escola Goronã e a farmácia: a função do wajanga (pajé) nos sistema de transmissão de conhecimentos típico dos habitantes de Kawerêtxikô e a dupla submissão no contexto da Escola Goronã. Gostaria de terminar a presente tese com algumas reflexões sobre esses dois pontos.

\section{O wajanga entre "aqueles que sabem"}

Em um interessante trabalho entre um grupo peruano conhecido como os Piro do baixo Urunbamba, Peter Gow (1991) nota que as diversas vilas que pesquisou nessa região eram identificadas por seus habitantes como relativamente civilizadas porque, entre outros fatores, elas possuíam escolas públicas com professores pagos pelo Estado peruano. Como no caso de Kawerêtxikô, a estrutura física da instituição de ensino formal era construída localmente, mas os salários dos professores e outros funcionários era responsabilidade do erário público. Ainda de maneira similar aos Tapayúna, os Piro se diferenciavam daqueles nativos que ainda viveriam nas matas, sem contato ou com contato muito restrito com os não-indígenas, os quais os próprios Piro consideravam não-civilizados. 
Com exceção dos graus de civilidade, ausente entre os Kaykwakhratxi, o contexto estudado por Gow pode ajudar a entender a realidade de Kawerêtxikô. No capítulo 8 de Of Mixed Blood (1981), o autor faz uma interessante comparação entre o ofício dos pajés piro e a instituição escolar. Sua interpretação tem como base a noção de que nesses dois contextos sociológicos relativamente distintos, podemos encontrar pessoas que são "gente que sabe" (idem :230, tradução minha para a expressão inglesa "people who know", presente em todo capítulo de Gow), no dizer nativo. Contudo, o pajé e o professor sabiam coisas diferentes, mas os dois eram imprescindíveis para que os Piro conseguissem manter relativamente estável seu sistema de parentesco. Assim, enquanto a escola de educação formal era o local onde se ganhava conhecimento para não se tornar escravo de algum potentado local, o xamanismo servia principalmente para domar ou domesticar os perigos da floresta, do selvagem, do não-civilizado (ibid idem :229-250)

Não tenho dúvidas de que o pajé Wotkàtxi é tido, em Kawerêtxikô, como um especialista, como alguém que sabe profundamente os meandros da cura pela terapêutica indígena. Esse é um outro dado em comum com os Piro: a Escola Goronã é tida como um centro de conhecimento independente, assim como o ofício do wajanga ou pajé. Deste modo, ainda como no caso estudado por Gow, tais conhecimentos se diferenciam substancialmente um do outro.

No caso dos Tapayúna, tal diferenciação está relacionada ao modos ou tipos específicos em que o conhecimento pode circular. Como já dito, apesar dos últimos não classificarem, por exemplo, o trabalho das técnicas em enfermagem ou do professor como em algum grau mais ou menos civilizado que o ofício do pajé, ainda assim há uma diferenciação entre os dois modos de saber. $\mathrm{Na}$ verdade, esses conhecimentos tem funções sociais diferentes: o ensino formal visa o engajamento em relações sociais menos assimétricas com os não-indígenas - e, nesse ponto, nos aproximamos novamente do contexto piro que tenta evitar a escravidão pelos nãoindígenas; por outro lado, o wajanga tem um papel central não só no tratamento das "doenças de índio", mas também na própria maneira como o conhecimento circula em Kawerêtxikô.

Essa circulação de conhecimento úteis, como o do artesanato - e Wotkàtxi era, além de pajé, um dos grandes artesãos de Kawerêtxikô -, segue um caminho diferente daquele conhecimento transmitido na Escola Goronã. Seu aprendizado não se dá pela 
educação formal, por aulas expositivas onde se diz e se escreve como algo deve ser feito. Essa circulação, na verdade, passa essencialmente pela observação daqueles outros "que sabem", no interesse na ação daqueles que dominam determinada técnica ou conhecimento que quer ser aprendido por alguém. Tal circulação se distancia, portanto, tando do campo do que é dito como também do recente campo do que é escrito.

Além disso, o pajé só autoriza alguém a assisti-lo mediante alguma contradádiva ou outra forma de pagamento. Ele pode escolher, ainda, não repassar seu conhecimento a ninguém e deixá-lo como 'herança' a seus parentes. Há, por fim, a possibilidade de passar somente uma parte do conhecimento, deixando uma outra encoberta para ser negociada ou herdada mais tarde. Foram justamente essas características da circulação do conhecimento xamânico que impediram, por exemplo, que existisse uma escola de xamãs entre os Piro, segundo outro texto de Gow (2010). Como fazer um pagamento único a um 'professor-xamã' e esperar que ele revele todo seu conhecimento a uma turma de dezenas de alunos, muitos dos quais não diretamente interessados no ofício do xamã e aparentados, de diferentes maneira, com o último?

Como visto no capítulo 3 , há, vez ou outra, aulas de artesanato ou o contar de determinado mito dentro da Escola Goronã. Isto se dá pelo caráter capilar das instituições indígenas ou indigenizadas: não estamos falando mais de entidades sociais fechadas, com uma exclusividade única, autorizada pelo Estado, na transmissão de determinados conhecimentos. Tratamos, agora, de um no local (sociológico e geográfico) em que, preponderantemente, tal ou qual conhecimento é repassado de maneira determinada. Para dar um exemplo já discutido anteriormente, a Casa dos Homens ou dos Guerreiros não é o local exclusivo da sociabilidade masculina, mas é preferencialmente lá que essa sociabilidade específica se desenvolve. Assim, só ocasionalmente o pajé Wotkàtxi era convidado a fazer alguma apresentação na instituição de ensino formal de Kawerêtxikô. No mais das vezes, aqueles interessados em seu ofício (de pajé ou de artesão) o observavam enquanto ele fazia uma peça ou entoava um cântico de cura. Da mesma maneira que o ensino formal em Kawerêtxikô não é obrigatório, também não há a obrigatoriedade de se formar pajés ou artesão e os interessados nessas técnicas é que precisam se mover para aprender. Encontramos aqui uma situação muito semelhante à descrita por Ingrid 
Weber entre os Kaxinawá, que notou que a transmissão de algum conhecimento se dá mais pela vontade do neófito do que pela capacidade de convencimento ou pela insistência do mestre:

Para os Kaxinawá, este [o aprendizado] é visto predominantemente como algo que decorre muito mais do esforço do aprendiz do que do desempenho do professor; o conhecimento é antes apre(e)ndido do que ensinado, como no caso de Edi, por exemplo, que conta ter aprendido as histórias porque era "atentoso" e quase toda noite queria ouvi-las de seu pai” (Weber, 2006 :171)

Como entre os Tapayúna, boa parte da tensão característica da escola nãoindígena entre professor/aluno se desvanece, na Escola Goronã e outras áreas de transmissão de conhecimento, como a formação do wajanga, pela noção de que o maior interessado, aquele que deve prestar atenção e efetivamente aprender, é o neófito.

Do mesmo modo, existem pessoas que conseguiram dominar relativamente bem as técnicas e conhecimentos não-indígenas e que não freqüentaram, ao menos regularmente, o ensino formal. Esse é o caso de Nokêrê, analisado no capítulo 3. Contudo, dada a importância cada vez maior das relações com os não-indígenas, a maioria dos Tapayúna decidiu que o modo de se relacionar com esses últimos não poderia ter nem o caráter erradico da experiência de formação de Nokêrê, nem o sofrimento da separação dos filhos que se mudavam para os centros urbanos da região para continuar seus estudos. Deste modo, a Escola Goronã tornou-se o lócus específico de transmissão do conhecimento não-indígena, ainda que não exclusivamente toda a experiência adquirida no trato com estes últimos se dê nela. Essa instituição opera na formalidade das aulas expositivas - ou, para ser mais exato, em uma formalidade diferente daquela que tipicamente o conhecimento é transmitido em Kawerêtxikô.

Os Tapayúna não deixaram de lado a maneira tradicional de transmissão e retransmissão do conhecimento. $\mathrm{Na}$ verdade, eles apenas somaram uma maneira diferente, até então desconhecida, de circulação de um novo saber. Além disso e mais importante, eles fizeram coincidir essa metodologia de ensino não-indígena com o 
conhecimento não-indígena em si. Assim, como argumenta Tônico Benites (2009) sobre os Ava-Kaiwá, as família extensas possuem pessoas que tratam quase que exclusivamente da boa formação das crianças para, por assim dizer, uma sociabilidade entre indígenas. Portanto, o que sugiro aqui é que, nesses contextos sociológicos em que a instituição de ensino formal não visa um reflorescimento ou fortalecimento de determinados traços culturais característicos de uma indianidade perdida ou em vias de se perder, a escola é efetivamente o local onde se aprende, principalmente mas não exclusivamente, a se relacionar com os não-indígenas.

O posto-de-saúde ou farmácia, nesse contexto, não tem a função última de circular um tipo determinado de conhecimento. O que a sede da terapêutica alopática faz efetivamente circular em Kawerêtxikô são, principalmente, os remédios. Exames para diagnósticos e tratamentos mais complexos são feitos, todos, nas cidades da região e, portanto, fora da aldeia. De todo modo, se os não-indígenas se tratavam de maneira relativamente eficaz com a alopatia antes do contato com os indígenas, então, na teoria do contato entre corpos diferentes que efetivamente se afetam mutuamente, a alopatia deve ter alguma agência positiva nos corpos dos Tapayúna, mais pontualmente depois que os últimos empreenderam um contato mais regular com os não-indígenas. Não é difícil notar que essa auto-representação que se faz da alopatia leva em conta, positivamente, o conhecimento do outro. O mesmo não pode ser dito da maneira como a terapêutica não-indígena acaba classificando o conhecimento ou o tratamento mais tradicional dos Kaykwakhratxi.

Assim, a saúde alopática entra no cotidiano de Kawerêtxikô como uma técnica da qual os moradores não entendem a fundo os princípios de agência, mas, ainda assim, confiam relativamente em sua eficácia. Isto não se dá por desinteresse dos indígenas. Existem tentativas de se conhecer mais a fundo a complexa técnica de tratamento dos males desse outro especial que são os não-indígenas. Conheço dois jovens homens de Kawerêtxikô que tentaram fazer cursos de técnicos em enfermagem em cidades da região do norte do Mato Grosso. Um deles me disse que abandonou o curso logo após seu casamento, já que precisava se mudar para a casa dos pais de sua esposa e prestar-lhes serviços. O outro também foi obrigado a se mudar de volta à Kawerêtxikô logo após o nascimento de seu primeiro filho: aproveitava, então, a oportunidade de sair da casa dos pais de sua esposa e construir uma nova residência relativamente independente. Assim, até o momento, nenhum um indígena, morador de 
Kawerêtxikô, conseguiu ser um operador, ainda que de menor importância, dessa técnica ou terapêutica que é inteiramente dominada pelos não-indígenas.

Aqui se pode fazer um novo paralelo com o trabalho de Peter Gow. Este autor argumenta que os professores Piro eram, em sua maioria, pessoas de fora das comunidades em que eles lecionavam. Isto porque não havia colégios de ensino médio na região, que só abrigava instituições de ensino regular básico. Deste modo, os pretendentes locais à docência precisavam escolher: ou se casar, procurar um emprego e ter filhos, adiando o avanço nos estudos formais e postergando o sonho de se tornar professor; ou continuar estudando com a ajuda de algum familiar, sem emprego e em uma instituição de ensino fora da região, suspendendo, nesse caso, qualquer planejamento de montar um núcleo familiar relativamente independente. Foi uma situação análoga a essa que tirou os dois jovens indígenas de Kawerêtxikô de seus cursos de técnico em enfermagem. Não é difícil enxergar que, apesar de todos os problemas citados da implantação do ensino formal público na região da TI Capoto Jarinã, os professores indígenas formados nessa região não sofrem mais com tal problema.

\section{A dupla submissão no contexto da educação formal em Kawerêtxikô}

Até aqui, explorei as possibilidades da dupla submissão apenas no campo específico da saúde alopática. Como essa área é sensivelmente mais 'entrincheirada' que a educação formal, a tentativa de fazer submeter duplamente os Tapayúna como "pacientes" e, ao mesmo tempo, "não-higienizados" ou "não-civilizados" se mostrou mais evidente nesse contexto. Contudo, penso que há situações específicas no campo do ensino formal onde também opera a tentativa de uma dupla ou múltipla submissão - ainda, é claro, que a tentativa de submissão não passe pela categoria de "paciente".

Deste modo, se boa parte do problema dos estudantes foi remediado com a instalação no ensino formal dentro da aldeia, o mesmo não se pode dizer da nova profissão de docente-indígena. Eles precisam regularmente dizer como e o que estão ensinando, por escrito e em Português, produzindo os tais planos de aula. Além disso, há reuniões regulares com o corpo docente/administrativo da Escola Goronã com o 
pessoal não-indígena da Secretaria de Educação, normalmente na cidade de Peixoto de Azevedo. Pude acompanhar Orengô em uma dessas reuniões, que se deu durante o segundo semestre de 2014, no fim do mês de outubro.

O ônibus de linha que nos levava à Peixoto atolou e, assim, havia atrasado algumas horas. Isto fez com que não chegássemos, eu e Orengô, pontualmente à reunião. Adentramos a sede da Secretaria de Educação com duas horas de atraso e, portanto, a reunião já havia começado sem nós.

Estávamos encaminhando o Plano Político e Pedagógico (PPP) aos nãoindígenas. A reunião contava com a presença de professores, diretores e outros funcionários de diversas escolas da região, indígenas e não-indígenas. Um grupo de cada instituição de ensino deixava o texto impresso do PPP, em Português, com uma funcionária e, após isso, tinha cerca de meia hora para apresentar, oralmente e também em Português, os principais pontos desse documento para todos os presentes. As carteiras da sala de reunião estavam organizadas em uma espécie de círculo e aqueles responsáveis pela apresentação levantavam-se de seus lugares e ocupavam o centro desse círculo.

Pelo fato de termos sido os últimos a chegar, não pude acompanhar a apresentação de todos os grupos. No momento em que sentávamos, se iniciava a explanação do PPP de uma escola de ensino fundamental da própria cidade de Peixoto de Azevedo. As funcionárias, todas mulheres, haviam preparados cartazes coloridos e, de maneira resumida, contaram como aquela escola havia surgido, qual era seu público principal e, por fim, fizeram um resumo das principais atividades que haviam desenvolvido, até então, durante o ano.

Quando a referida apresentação se finalizou, a coordenadora da reunião pediu, então, que nos apresentássemos. Nenhum de nós tinha qualquer ideia de que o encontro seria organizado daquela maneira, com uma exposição oral e formal de cada escola. Tendo isso em conta, Orengô disse apenas que era "Tapayúna da aldeia Kawerêtxikô" e que havia trazido o PPP da escola desta localidade para a Secretaria de Educação. Eu acrescentei que era um antropólogo em campo e que havia assessorado os Tapayúna na produção daquele documento. Orengô levantou e entregou uma cópia do referido documento à coordenadora. Sabíamos quem era a coordenadora da reunião pois, além do fato dela ter nos interpelado para nos 
apresentarmos a todos os outros, ela também havia recebido o PPP do grupo da escola que tinha acabado de se apresentar.

Essa mulher, uma senhora não-indígena de cerca de 60 anos, nos informou, então, que éramos a última escola que ainda não havia se apresentado e que, portanto, deveríamos fazer nossa exposição o mais brevemente possível. Orengô, cujo Português é bastante claro e praticamente sem qualquer deslize da gramática normativa, disse que não iria se apresentar pois havia sido informado apenas da entrega do PPP, não sabendo nada sobre qualquer exposição sobre o mesmo. A senhora insistiu mais uma vez e Orengô, educadamente, se recusou novamente.

Nesse momento, a senhora, também muito educadamente, disse que a parte das apresentações estava, então, finalizada e que ela iria fazer algumas considerações sobre a apresentação do PPP de cada grupo. Essas considerações gerais tomaram mais de uma hora e, dado o contexto descrito acima, eu e Orengô estávamos bastante deslocados. No fim, depois que todos se despediram, a referida senhora pediu para falar particularmente com Orengô. Os dois se reuniram por cerca de 5 minutos enquanto eu observava à distância, sem conseguir escutar o que era dito. Por fim, fomos para um hotel no intuito de, no outro dia, fazer a compra de alimentos para Orengô e sua família, já que saímos da reunião em um horário em que todos os mercados da cidade já estavam fechados.

Durante tais compras, inquiri Orengô sobre o que havia sido conversando naquela ocasião com a coordenadora da reunião. Ele contou, então, que ela dissera que os indígenas estavam em falta com a Secretaria de Educação. O pessoal dessa última instituição, na opinião daquela senhora, fazia de tudo para que os indígenas tivessem a melhor educação escolar possível. Enquanto isso os indígenas, que deveriam ser os maiores interessados, pouco faziam para que o ensino formal melhorasse entre eles. Eles chegavam atrasados à reunião ou então nem mesmo apareciam, caso do pessoal representante da Escola do Metyktire, que não havia justificado sua falta. Por fim, ela comentou que não gostara nada da negativa de Orengô para fazer a apresentação do PPP da instituição de ensino dos Tapayúna. Ele me esclareceu, então, que tentou argumentar com ela que não havia nada preparado e que esse era o motivo de sua negação. Ela teria respondido, segundo Orengô: "É, os indígenas nunca tem mesmo nada preparado." Orengô me disse, em tom jocoso, que aquela mulher não sabia nada dos índios. 
O desenrolar dessa reunião evidencia que a submissão mais básica ou inicial, aquela que classifica os indígenas, logo de saída, como "não-civilizados" ou "avessos às noções básicas de higiene", se não opera nas relações entre os indígenas estudantes e os professores, ambos indígenas, na aldeia, acaba operando em outras searas. Como mostra esse exemplo, essa parece ser exatamente a realidade quando os funcionários da educação de Kawerêtxikô precisam participar de reuniões ou outros encontros com os não-indígenas responsáveis, em algum grau, pela educação formal entre indígenas e não-indígenas na região.

Gostaria de sugerir, por fim, que a tônica do tratamento dispensado pelos nãoindígenas aos Tapayúna, entre outros indígenas nas cidades da região, parece ser a seguinte: "até que se prove o contrário, a condição de vocês, indígenas, é sinônimo de falta de civilidade", entre outras faltas, como a preguiça congênita ou a violência generalizada. Ainda assim, quando determinado indígena consegue se mostrar razoavelmente "civilizado" a partir dos valores dos não-indígenas citadinos, com um comerciante kayapó na cidade de Colider, a tendência destes últimos é dizer que, com isso, eles estão deixando de ser indígenas. É fácil compreender, dessa forma, que os Tapayúna, entre outros povos da região, que precisam visitar a cidade, acabem, na maioria das vezes, ignorando e não se dispondo a responder argumentos desse tipo. 


\section{Bibliografia em ordem alfabética}

ALBERT, Bruce. 'Ethnographic Situation' and Ethnic Movements: Notes on postMalinowskian fieldwork”. Critical Anthropology, n. 57, 1997, :53-65. . "Introdução". In: RAMOS, Alcida Rita \& ALBERT, Bruce (orgs.). Pacificando o branco: cosmologias do contato no norte-amazônico. São Paulo: Editora UNESP, Imprensa Oficial do Estado, 2002.

ALCANTARA NETO, Martiniano Sardeiro de. O caso Haximu: a construção do crime de Genocídio em um processo criminal. Rio de Janeiro: dissertação de mestrado apresentada ao Programa de Pós-Graduação em Antropologia Social do Museu Nacional, Universidade Federal do Rio de Janeiro, 2007.

ALMEIDA, Rita Heloísa de. O Diretório dos índios: um projeto de "civilização" no Brasil do século XVIII. Brasília: Editora Universidade de Brasília, 1997.

ALTHUSSER, Louis. Ideologia e aparelhos ideológicos de Estado. Lisboa/São Paulo: Presença e Martins Fontes, 1985.

AMOROSO, Marta Rosa. "Mudança de hábito: catequese e educação para índios nos aldeamentos capuchinos." Revista Brasileira de Ciências Sociais, vol. 13, n. 37, :101-114, São Paulo, junho de 1998.

ANDRADE, Karenina Vieira. A ética Ye'kuana e o espírito do empreendimento. Brasília: tese de doutorado apresentada ao Programa de Pós-Graduação em Antropologia Social do Departamento de Antropologia da Universidade de Brasília, 2007.

ANDRADE, Karenina Vieira. "O processo de escolarização entre os Ye'kuana (RR)." In: II Reunião Equatorial de Antropologia, 2009, Natal RN. Anais da II Reunião 
Equatorial de Antropologia e XI Reunião de Antropólogos do Norte e Nordeste, 2009.

BARTH, Fredrik. "Os grupos étnicos e suas fronteiras." In: O guru, o iniciador e outras variações antropológicas. Rio de Janeiro, Contra Capa, 2000.

BATISTA DE LIMA, Daniela. "Vamos amansar um branco para pegar as coisas": elementos da etnohistória Kajkhwakratxi (Tapayuna). Brasília: dissertação de mestrado apresentada ao Programa de Pós-Graduação em Antropologia Social do Departamento de Antropologia da Universidade de Brasília, 2012.

BENITES, Tonico. A escola na ótica dos Ava Kaiowá: impactos e interpretações indígenas. Rio de Janeiro: dissertação de mestrado apresentada ao Programa de PósGraduação em Antropologia Social do Museu Nacional da Universidade Federal do Rio de Janeiro, 2009.

BUCHILLET, Dominique. Bibliografia crítica de saúde indígena no Brasil (18442006). Quito - Equador: Ediciones Abya-Yala, 2006.

CAMARGO, Eliane e NHII, Celia. "Grafando o ágrafo: um ponto de vista linguístico a partir do caxinauá" In: SILVA, Aracy Lopes da \& FERREIRA, Mariana Kawall. Antropologia, história e educação: a questão indígena e a escola. $2^{a}$. ed. São Paulo: Global, 2001.

CAMARGO, Nayara da Silva. Língua Tapayúna: aspectos sociolinguísticos e uma análise fonológica preliminar. Campinas: dissertação de mestrado apresentada ao Programa de Pós-Graduação em Linguística do Instituto de Linguagem da Universidade Estadual de Campinas, 2010.

. Tapayuna (Jê): aspectos morfossintáticos, históricos e sociolinguísticos. Campinas: tese de doutorado apresentada ao Programa de Pós-Graduação em 
Linguística do do Instituto de Linguagem da Universidade Estadual de Campinas, 2015.

CARDOSO DE OLIVEIRA, Roberto. O índio e o mundo dos brancos: uma interpretação sociológica da situação dos Tukúna. São Paulo: Pioneira, [1964] 1972.

A sociologia do Brasil indígena. Brasília e Rio de Janeiro: Editora Universidade de Brasília e Tempo Brasileiro, 1978.

- Prefácio In: RAMOS, Alcida Rita. Hierarquia e simbiose: relações intertribais no Brasil. São Paulo: Hucitec, 1980.

CCPY. Research and ethics: the Yanomami case. Brazilian contributions to the Darkness in El Dorado controversy. Documento n. 02, Dezembro de 2001.

CLASTRE, Pierre. A sociedade contra o Estado: pesquisas de antropologia política. Rio de Janeiro: Francisco Alves, 1978.

D'ANGELIS, Wilmar da Rocha. Como nasce e por onde se desenvolve uma tradição escrita em sociedades de tradição oral? Campinas: Curt Nimuendajú, 2007.

Aprisionando sonhos: a educação escolar indígena no Brasil. Campinas: Curt Nmuendajú, 2012.

DUMONT, Louis. Homo hierachicus: o sistema de castas e suas implicações. São Paulo: EDUSP, 1997.

O individualismo: uma perspectiva antropológica da ideologia moderna. Rio de Janeiro: Rocco. 1985 
EVANS-PRITCHARD, Edward E. Os Nuer: uma descrição do modo de subsistência e das instituições políticas de um povo nilota. São Paulo: Editora Perspectiva, 2013.

FARAGE, Nádia. As muralhas dos sertões: os povos indígenas do Rio Branco e a colonização. Rio de Janeiro: Paz e Terra \& ANPOCS, 1991.

FOUCAULT, Michel. O nascimento da clínica. Rio de Janeiro: Forense Universitária, 2008.

FERRAZ, Iara. "Lições da Escola Parkatêjê." In: SILVA, Aracy Lopes da \& FERREIRA, Mariana Kawall. Antropologia, história e educação: a questão indígena e a escola. São Paulo: Global, 2001.

FRANCHETTO, Bruna (org.). Alto Xingu: uma sociedade multilíngue. Rio de Janeiro: Museu do Índio / Funai, 2011.

. "A guerra dos alfabetos: os povos indígenas na fronteira entre o oral e o escrito." Mana, vol. 14, n.01, abril/2008 , :31-59.

FREIRE, José Ribamar Bessa. Rio Babel: as histórias das línguas na Amazônia. Rio de Janeiro: Atlântica, 2004.

FRIEDMAN, Meyer e FREDLAND, Gerald W. As dez maiores descobertas da medicina. São Paulo: Companhia das Letras, 2006.

GALLOIS, Dominique Tilkin, TESTA, Adriana Queiroz, VENTURA, Augusto e BRAGA, Leonardo Viana. "Etnologia brasileira: alguns caminhos de uma antropologia indígena.”, :01-28. Tradução de "Ethnologie brésilienne. Les voies d'une anthropologie indigène", Brésil(s) [En ligne], 09, mai 2016. Disponível em https://www.academia.edu, com acesso em 08/09/2016.

GALVÃO, Eduardo. Encontro de sociedades: índios e brancos no Brasil. (Coleção estudos brasileiros n. 29). Rio de Janeiro: Paz e Terra, 1979. 
GERALD, João Wanderley. "Culturas orais em sociedades escritas." Revista Educação \& Sociedade, ano XXI, n. 73, dezembro de 2000, :100-108.

GIANNINI,. Isabelle Vidal. "A dimensão educativa do projeto de manejo socioambiental na área indígena Xikrin do Cateté.” In: SILVA, Aracy Lopes da \& FERREIRA, Mariana Kawall. Antropologia, história e educação: a questão indígena e a escola. 2a . ed. São Paulo: Global, 2001.

GOLDMAN, Emma. O indivíduo, a sociedade e o Estado e outros ensaios. São Paulo: Hedra, 2007.

GORDON, Richard. A assustadora história da medicina. Rio de Janeiro: Ediouro, 1996.

GORDON, César. Economia selvagem: ritual e mercadoria entre os XikrinMebêngôkre. São Paulo/ Rio de Janeiro: Editora da Unesp, ISA e NUTI, 2006.

GOW, Peter. Of mixed blood: kinship and history in Peruvian Amazonia. . Oxford: Clarendon Press, 1991.

. “Podia leer Sangama?: Sistemas graficos, lenguaje y shamanismo entre los Piro (Perú Oriental). Revista da FAEEBA. Salvador, v. 19, n. 33, , jan/jun 2010, :105-117.

GRUPIONI, Luís Donisete Benzi. Olhar longe, porque o futuro é longe. Cultura, escola e professores indígenas no Brasil. São Paulo: tese de doutorado apresentada ao Programa de Pós-Graduação em Antropologia Social do Departamento de Antropologia da Faculdade de Filosofia, Letras e Ciências Humanas da Universidade de São Paulo, 2008. 
HOUASSIS, Antonio e VILLAR, Mauro Sales. Dicionário Houaiss da Língua Portuguesa. Rio de Janeiro: Objetiva, 2009.

HOWARD, Catherine. "A domesticação das mercadorias: estratégias Wai wai.”. In: RAMOS, Alcida Rita \& ALBERT, Bruce (orgs.). Pacificando o branco: cosmologias do contato no norte-amazônico. São Paulo: Editora UNESP, Imprensa Oficial do Estado, 2002.

ISA. Almanaque Parque Indígena do Xingu: 50 anos. São Paulo: Instituto Socioambiental, 2011.

LACERDA, Rosane. Os povos indígenas e a Constituinte - 1987-1988. Brasília: Conselho Indigenista Missionário (CIMI), 2008.

LADEIRA, Maria Elisa. "Desafios de uma política para a educação escolar indígena." Revistas de Estaudos e Pesquisas, FUNAI, Brasília, v. 1, n. 2, dez. 2004, :141-145.

LADEIRA, Maria Elisa. "De bilhetes e diários: oralidade e escrita entre os Timbira” In: SILVA, Aracy Lopes da \& FERREIRA, Mariana Kawall. Antropologia, história e educação: a questão indígena e a escola. São Paulo: Global, 2001.

LASMAR, Cristiane. "Conhecer para transformar: os índios do rui Uaupés (alto rio Negro) e a educação escolar.” Tellus, vol. 09, n. 16, jan/jun 2009.

LÉVIS-STRAUSS, Claude. Tristes trópicos. São Paulo: Companhia das Letras, 1996.

As estruturas elementares do parentesco. Petrópolis: Vozes, 1992.

O pensamento selvagem. Campinas: Papirus, 1989. 
. "A eficácia simbólica." in Antropologia estrutural. Rio de Janeiro: Tempo Brasileiro, 1975.

LOPES DA SILVA, Aracy e NUNES, Angela e LOPES, Ana Vera (orgs.). Crianças indígenas: ensaios antropológicos. São Paulo: Global, 2001a.

LOPES DA SILVA, Aracy. "A educação indígena entre diálogos interculturais e multidiscipinares: introdução.” In: __ e FERREIRA, Mariana Kawall. Antropologia, história e educação: a questão indígena e a escola. $2^{\mathrm{a}}$ ed. São Paulo: Global, 2001b.

LUCIANO, Gersem. "Indígenas no ensino superior: novo desafio para as organizações indígenas e indigenistas no Brasil.” In: SMILJANIC, Maria Inês, PIMENTA, José e BAINES, Stephen Grant (org.s). Faces da indianidade. Curitiba: Nexo Design, 2009.

Educação para manejo e domesticação do mundo, entre a escola ideal e a escola real: os dilemas da educação escolar indígena no Alto Rio Negro. Brasília: tese de doutorado apresentada ao Programa de Pós-Graduação em Antropologia Social do Departamento de Antropologia da Universidade de Brasília, 2011.

MACENA, João Marcelo de Oliveira. "Isso é coisa de vocês": os índios canela e a escola. Brasília: dissertação de mestrado apresentada ao Programa de Pós-Graduação em Antropologia Social da Universidade de Brasília, 2007.

MALINOWSKI, Bronislaw. Argonautas do pacifico ocidental: um relato do empreendimento e da aventura dos nativos nos arquipélagos da Nova Guiné, Melanésia. Coleção Pensadores, v.43. São Paulo: Abril Cultural, 1976.

MAUSS, Marcel. "Ensaio sobre a dádiva.” In: Sociologia e antropologia. São Paulo: Cosac \& Naify, 2003. 
MENEZES, Maria Lucia Pires. Parque Indígena do Xingu: a construção de um território estatal. Campinas: Editora da Unicamp, 2000.

VIDAL, Lux Boelitz. "O mapeamento simbólico das cores na sociedade indígena Kayapó-Xikrin do sudoeste do Pará." In: SILVA, Aracy Lopes da \& FERREIRA, Mariana Kawall. Antropologia, história e educação: a questão indígena e a escola. $2^{a}$. ed. São Paulo: Global, 2001.

MAIA, João Marcelo Ehlert. “As Ideias que Fazem o Estado Andar: Imaginação Espacial, Pensamento Brasileiro e Território no Brasil Central.” DADOS - Revista de Ciências Sociais, Rio de Janeiro, vol. 53, $n^{\circ}$ 3, 2010, pp. 621 a 655.

MARTINS, Ana Luísa. República: um outro olhar. $2^{\text {a }}$. Edição. São Paulo: Contexto, 1990.

MAUSS, Marcel. "Ensaio sobre a dádiva. forma e razão da troca nas sociedades arcaicas". In: . Sociologia e Antropologia, v. II. São Paulo : Edusp, 1974

MEC. Referencial curricular nacional para as escolas indígenas. Brasília: MEC/SEF, 1998.

MENEZES, Gustavo Hamilton de Sousa. "A busca pela escrita através da escola: estratégia interétnica e transformação social entre os Yanonamami de Maturacá/AM." Revista Textos \& Debates, Boa Vista, n. 20, janeiro/junho de 2013, :40-63.

MINDLIN, Betty. "A política educacional indígena no período 1995-2002: algumas reflexões.” Revista de Estudos e Pesquisas, FUNAI, Brasília, v.01, n.02, dez. 2004, :101-140.

NINCAO, Onilda Sances. "Kóho Yoko Hovôvo/O Tuiuú e o Sapo": identidade, biletramento e política linguística na formação continuada de professores Terena. Campinas: tese de doutorado apresentada ao Instituto de Estudos de 
Linguagem, Programa de Pós-Graduação em Linguística Aplicada da Universidade Estadual de Campinas, 2008.

NORBERT, Elias. O Processo Civilizador. v. 1. Rio de Janeiro: Jorge Zahar, 1993a.

NORBERT, Elias. O Processo Civilizador. v. 2. Rio de Janeiro: Jorge Zahar, 1993b.

PALADINO, Mariana \& ALMEIDA, Nina Paiva. Entre a diversidade e a desigualdade: uma análise das políticas públicas para a educação escolar indígena no Brasil dos governos Lula. Rio de Janeiro: Contra Capa Livraria; LACED/Museu Nacional/UFRJ, 2012.

PEIRANO, Mariza G. e S. “Antropologia no Brasil (alteridade contextualizada)”. In: Sergio Miceli (org.). O que ler na ciência social brasileira (1970-1995). São Paulo: Sumaré, Anpocs, 1999. :225-266.

PÉREZ, Andrea Lisset. "Escola indígena: uma reflexão sobre seus fundamentos teóricos, ideológicos e políticos". Revista Perspectiva, Florianópolis, v. 25, n. 1, janeiro/junho, 2007, :227-244.

PIERONI, Geraldo. Os excluídos do Reino: A Inquisição Portuguesa e os degredados para o Brasil-Colônia. Brasília: Editora Universidade de Brasília, 2000.

PORTER, Roy. Cambridge História da medicina. Rio de Janeiro: Livraria e Editora Revinter, 2008.

RAMOS, Alcida Rita. Hierarquia e simbiose: relações intertribais no Brasil. São Paulo: Hucitec, 1980.

. "Ethnology Brazilian Style" Cultural Anthropology 5 (4), 1990, :452-472. 
. "Projetos indigenistas no Brasil independente" Etnográfica, v. IV, n. 02, $2000,: 267-283$.

. "Do engajamento ao desprendimento." Revista Campos, v. 08, n. 01, 2007, $: 11-32$.

RAMOS, Alcida Rita \& ALBERT, Bruce. Pacificando o branco: cosmologias do contato no norte-amazônico. São Paulo: Editora UNESP, Imprensa Oficial do Estado, 2002.

SCHADEN, Egon. Aculturação indígena: ensaio sôbre fatôres e tendências da mudança cultural de tribos índias em contacto com o mundo dos brancos. São Paulo: Faculdade de Filosofia, Ciências e Letras da USP, 1964.

SEEGER, Anthony. Nature and culture and their transformations in the cosmology and social organization of the Suyá, a ge-speaking tribe of Central Brazil. Chicago: University of Chicago, 1974.

Why Suyá Sing: a musical anthropology of an Amazonian people. Urbana \& Chicago: University of Illinois Press, 1987.

SILVA, Aracy Lopes da \& FERREIRA, Mariana Kawall. Antropologia, história e educação: a questão indígena e a escola. São Paulo: Global, 2001.

SILVA, Cristina Dias da. Cotidiano, saúde e política. Uma etnografia dos profissionais da saúde indígena. Brasília: tese de doutorado apresentada ao Programa de Pós-Graduação em Antropologia Social do Departamento de Antropologia da Universidade de Brasília, 2010.

SIMMEL, Georg. "The triad" (:145-169) In: WOLFF, Kurt H. (ed.). The sociology of Georg Simmel. Illinois: The Free Press, 1950. 
SMILJANIC, Maria Inês. "Da observação à participação: reflexões sobre o ofício do antropólogo no contexto do Distrito Sanitário Yanomami”. Série Antropologia, vol. 417, Brasília, Universidade de Brasília, 2008.

SOUSA, Cássio Noronha Inglez de. "Aprendendo a viver junto: reflexões sobre a experiência escolar Kayapó-Gorotire.” In: SILVA, Aracy Lopes da \& FERREIRA, Mariana Kawall. Antropologia, história e educação: a questão indígena e a escola. São Paulo: Global, 2001.

SOUZA LIMA, Antonio Carlos de. Um grande cerco de paz: poder tutelar, indianidade e formação do Estado no Brasil. Petrópolis: Vozes, 1995

. "Revisitando a tutela: questões para pensar as políticas públicas para povos indígenas.” In: TEIXEIRA, Carla Costa \& GARNELO, Luiza (org.s). Saúde indígena em perspectiva: explorando suas matrizes históricas e ideológicas. Rio de Janeiro: Fiocruz, 2014, (:27-58).

TASSINARI, Antonella Maria Imperatriz. "Escola indígena: novos horizones teóricos, novas fronteiras de educação.” In: LOPES DA SILVA, Aracy e FERREIRA, Mariana Kawall Leal (orgs.).Antropologia, história e educação: a questão indígena e a escola. São Paulo: Global, 2001a, (:48-70).

TASSINARI, Antonella Maria Imperatriz. "Da civilização à tradição: os projetos de escola entre os índios do Uaça." In: LOPES DA SILVA, Aracy e FERREIRA, Mariana Kawall Leal (orgs.). Antropologia, história e educação: a questão indígena e a escola. São Paulo: Global, 2001b, (:157-195).

TEIXEIRA, Carla Costa \& SILVA, Cristina Dias. “Antropologia e saúde indígena: mapeando marcos de reflexão e interfaces de ação.“ Anuário Antropológico, 2002, v.1, 2013, :35-57.

TEIXEIRA, Carla Costa. "Fundação Nacional de Saúde. A política brasileira de saúde indígena vista através de um museu." Etnográfica, 2008a, n. 12, v. 2, :323-351. 
"Interrompendo rotas, higienizando pessoas: técnicas sanitárias e seres humanos na ação de guardas e visitadoras sanitárias." Ciência e Saúde Coletiva, n. 13 , v. $3,: 2008,965-974$.

- "A produção política da repulsa e os manejos da diversidade na saúde indígena brasileira." Revista de Antropologia, São Paulo, USP, 2012, v. 55, n. 02, :567-608.

TEIXEIRA, Carla Costa \& GARNELO, Luiza (org.s). Saúde indígena em perspectiva: explorando suas matrizes históricas e ideológicas. Rio de Janeiro: Fiocruz, 2014.

TESTA, Adriana Queiroz. "Entre o canto e a caneta: oralidade, escrita e conhecimento entre os Guarani Mbya." Educação e pesquisa, São Paulo, v. 34, n. 2, :291-307, maio/ago 2008.

THE TRIBE that hides from man. Direção: Andrew Cowell. Produção: Associated Television (ATV), 1970. Local: Reino Unido: 1970. 75 min. Colorido. Disponível em https://www.youtube.com/watch?v=HhAvuPlhdNA, com acesso em 14/08/15.

VAINFAS, Ronaldo (org.). Confissões da Bahia: Santo Ofício da Inquisição de Lisboa. São Paulo: Companhia das Letras, 1997.

VIOTTI, Emília. Da Monarquia à República: momentos decisivos. $6^{\mathrm{a}}$ ed. São Paulo: Fundação Editora da UNESP, 1999.

VIVEIROS DE CASTRO, Eduardo Batalha. A inconstância da alma selvagem e outros ensaios de antropologia. São Paulo: Cosac \& Naify, 2002.

WEBER, Ingrid. Um copo de cultura: os Huni Kuin (Kaxinawá) do rio Humaitá e a escola. Rio Branco: EDUFAC, 2006. 


\section{Anexo 01}

Listagem inicial dos mortos nos genocídios que sofreram os Tapayúna

Digitado por Martiniano Alcântara Neto a partir das notas tomadas por Nayara Camargo, com a tradução de Orengô Tapayúna. A listagem foi ditada em língua materna por Katkhytxi Tapayúna e Kôkôtxi Tapayúna, coma ajuda de Ôketxi Tapayúna. Os depoimentos foram colhidos in loco, na Aldeia Kawêrêtxico (Nova) na manhã do dia 03/12/2012

Vítimas informadas por Katkhrytxi Tapayúna da Aldeia Kawêrêtxikô (Antiga)

\begin{tabular}{|l|l|}
\hline \multicolumn{1}{|c|}{ Nome da vítima } & \multicolumn{2}{c|}{ Parentesco conhecido } \\
\hline Nhiketxim & mãe de Oketi, mulher de Kàtkhrytxi \\
\hline Rômnotxi & \\
\hline Wotkàtxi & \\
\hline Tôtndi & mulher de Wetxi \\
\hline Wetxi & \\
\hline & irmã de Katkhrytxi \\
\hline Hwĩkà & irmã de Katkhrytxi \\
\hline Ndokêndi & sobrinho de Katkhrytxi \\
\hline Tôwâj & tio de Katkhrytxi \\
\hline Katkhaytxi & mãe de Katkhrytxi \\
\hline Weneti & irmão de Katkhrytxi \\
\hline Nhîkendi & irmão de Katkhrytxi \\
\hline Wëngrôtxi & Irmão de Katkhrytxi \\
\hline Totkhrembe & tio de Katkhrytxi \\
\hline Wëntũtÿtxi & \\
\hline Wëndentxi & \\
\hline
\end{tabular}




\begin{tabular}{|l|l|} 
Wetaktxi & padrinho de Katkhrytxi \\
\hline Werãtxi & padrinho de Katkhrytxi \\
\hline Nhîketxi & cunhado de Katkhrytxi \\
\hline $\begin{array}{l}\text { Nhikêtxi } \\
\text { Ngejkandêtxi }\end{array}$ & $\begin{array}{l}\text { cunhado de Katkhrytxi } \\
\text { mulher de Nhikêtxi }\end{array}$ \\
\hline Tewjawûtxi & tio de Nôkêrê, cacique da Aldeia Kawêrêtxikô (Antiga) \\
\hline Ngejwõntxi & mulher de Tewjawûtxi \\
\hline Tôtnõrõ & padrinho de Katkhrytxi \\
\hline Kôkôtetêtxi & mulher de Katkhrytxi \\
\hline Rikô & sogra de Katkhrytxi \\
\hline Ikejngurãtxi & padrinho de Katkhrytxi \\
\hline Ngejndorotxi & madrinha de Katkhrytxi \\
\hline Roptyktxi & padrinho de Katkhrytxi \\
\hline Ngejtëmtxi & mulher de Katkhrytxi \\
\hline Kunîtxi & pai de Ngejtëmtxi, sogro de Katkhrytxi \\
\hline Wejndytûmtxi & cunhado de Katkhrytxi \\
\hline Ngejlêtxi & mulher Katkhrytxi \\
Nbikêktxi & marido de Rikô \\
\hline Werãtxi & padrinho de Katkhrytxi \\
\hline Ngeûeptxi & irmã da Ôkêtxi (esta última ainda viva, atual mulher de Katkhrytxi) \\
\hline Kajwetxi & esposa de Kunitxi \\
\hline Nangmàtxi & primo de Igawû \\
\hline Mothe & primo de Wajgawû \\
\hline Ngejkhràtxi & mãe de Rikô \\
\hline Nanghràtxi (2) & primo de Katkhrytxi \\
\hline Wêjwêtxi & primo de Katkhrytxi \\
\hline Wythytxi & avó de Katkhrytxi \\
\hline
\end{tabular}

Vítimas ditadas por Kôkôtxi da Aldeia Hotxikhrô 


\begin{tabular}{|c|c|}
\hline Hwandytxi & primeiro marido de Kôkôtxi \\
\hline Wetaktxi & irmão de Hwandytxi \\
\hline Ikêjbet & marido da irmã de Kôkôtxi \\
\hline Wândytxi & irmã de Kôkôtxi \\
\hline Kahrâtxi & cunhada de Kôkôtxi \\
\hline Ikêtxi & marido Kahrâtxi \\
\hline Ngejkhrãtxi & irmão de Kôkôtxi \\
\hline Wêthyrotetxi & marido de Ngejkhrãtxi \\
\hline Tôtkhrekahry & cacique da Aldeia Hotxikhrô \\
\hline Wetxindi & mulher de Nôkêrê \\
\hline Tebkatxi & primo Kôkôtxi \\
\hline Wyjtxi & avó de Kôkôtxi \\
\hline Kuwëkhrãtâtxi & avô de Kôkôtxi \\
\hline Wëjtyroptxi & marido de Tyrytôri \\
\hline Tyrytôri & prima de Kôkôtxi \\
\hline Hwîkôrô & prima Kôkôtixi, mãe de Nôkêrê (este último ainda vivo) \\
\hline Tôtkutê & marido de Hwîkôrô \\
\hline Ikëjwywa & mulher de Wendêtxindi, prima de Kôkôtxi \\
\hline Wendêtxindi & marido de Ikëjwywa \\
\hline \multicolumn{2}{|l|}{ Ndojtâkô } \\
\hline Ikëjritnotxi & outro cacique da Aldeia Hotxikhrô \\
\hline Kaywetxi & mulher de Ikëjritnotxi \\
\hline Iotkhrejrôtxi & irmão de Rikô \\
\hline Wijnhîteptxi & mulher de Iotkhrejrôtxi \\
\hline Tebwûnûtxi & pai de Kôkôtxi \\
\hline Ngejrotxi & mãe de Kôkôtxi \\
\hline Wëjtywôrô & padrinho de Kôkôtxi \\
\hline Ngejtôwetxi & mulher de Wëjtywôrô \\
\hline Wewetxi & avô de Wëjtywôrô \\
\hline Ngejwôtxi & avó de Wëjtywôrô \\
\hline Wëtûmtxi & marido de Kuwëkhà, padrinho de Kôkôtxi \\
\hline Kuwëkhà & mulher de Wëtûmtxi \\
\hline Wejngangôwetxi & marido de Hwînguêrëtxi \\
\hline Hwînguêrëtxi & padrinho de Wejngangôwetxi \\
\hline Kàtkhwàtxi & marido de Wyjndiketxi \\
\hline
\end{tabular}


